Prepared in cooperation with the Stark-Tuscarawas-Wayne Joint Solid Waste Management District

\title{
Summary of Hydrologic Data for the Tuscarawas River Basin, Ohio, with an Annotated Bibliography
}

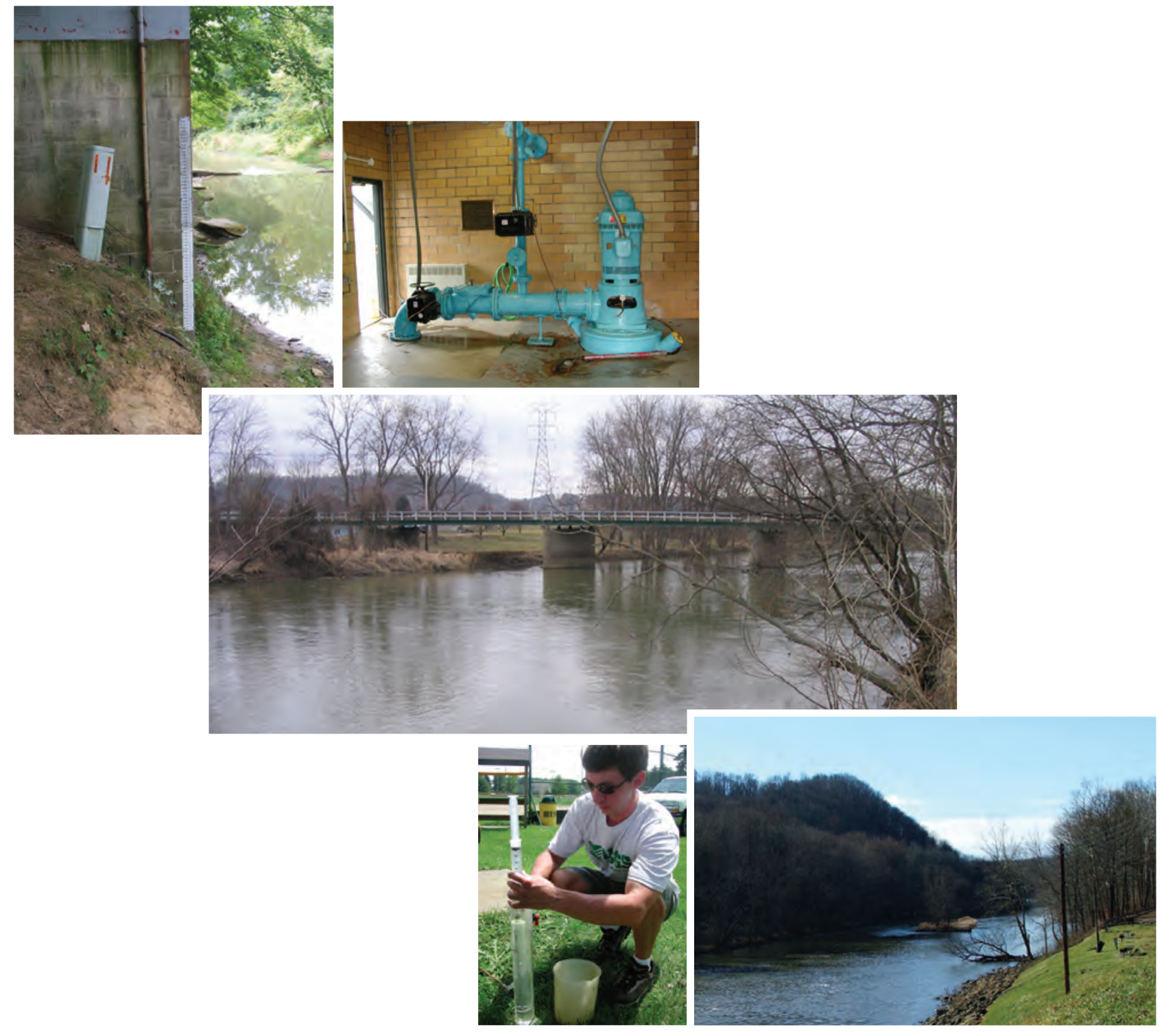

Scientific Investigations Report 2010-5010 



\section{Summary of Hydrologic Data for the Tuscarawas River Basin, Ohio, with an Annotated Bibliography}

By Ralph J. Haefner and Laura A. Simonson

Prepared in cooperation with the Stark-Tuscarawas-Wayne Joint Solid Waste Management District

Scientific Investigations Report 2010-5010 


\section{U.S. Department of the Interior \\ KEN SALAZAR, Secretary \\ U.S. Geological Survey \\ Marcia K. McNutt, Director}

\section{U.S. Geological Survey, Reston, Virginia: 2010}

For more information on the USGS - the Federal source for science about the Earth, its natural and living resources, natural hazards, and the environment, visit http://www.usgs.gov or call 1-888-ASK-USGS

For an overview of USGS information products, including maps, imagery, and publications, visit http://www.usgs.gov/pubprod

To order this and other USGS information products, visit http://store.usgs.gov

Any use of trade, product, or firm names is for descriptive purposes only and does not imply endorsement by the U.S. Government.

Although this report is in the public domain, permission must be secured from the individual copyright owners to reproduce any copyrighted materials contained within this report.

Suggested citation:

Haefner, R.J., and Simonson, L.A., 2010, Summary of hydrologic data for the Tuscarawas River Basin, Ohio, with an annotated bibliography: U.S. Geological Survey Scientific Investigations Report 2010-5010, 115 p.

ISBN 978-1-4113-2766-5

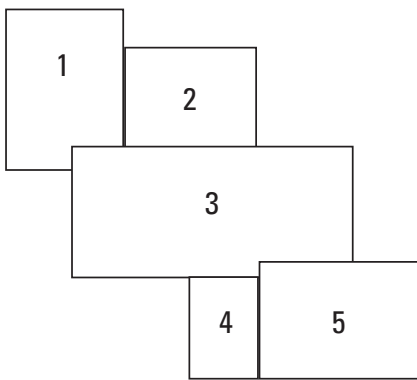

Cover photographs:

1. Staff gage on Indian Fork below Atwood Lake Dam near New Cumberland, Tuscarawas County, Ohio.

2. Public supply well at Dover, Tuscarawas County, Ohio.

3. Tuscarawas River upstream of Coshocton, Coshocton County, Ohio.

4. USGS Hydrologic Technician Brian Mailot obtaining water sample.

5. Tuscarawas River below Dover Dam, Tuscarawas County, Ohio. 


\section{Contents}

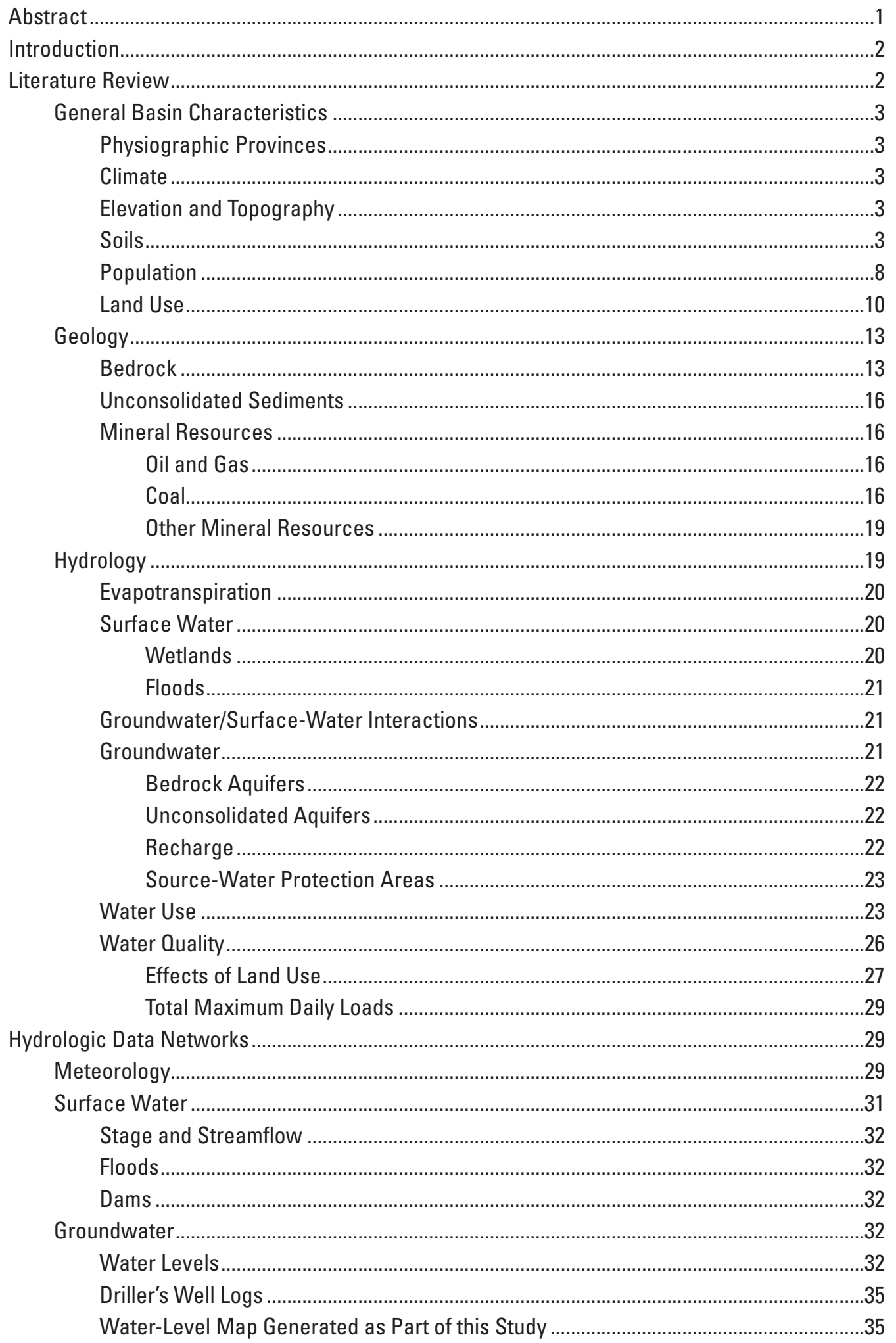




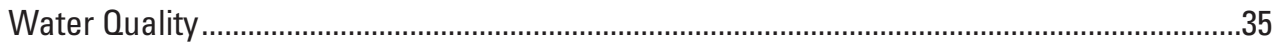

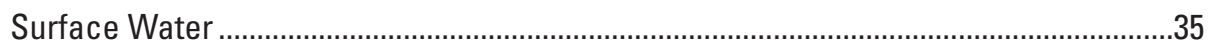

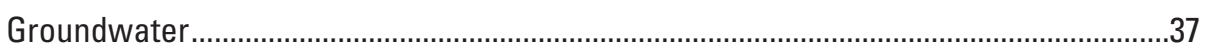

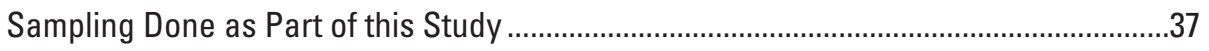

Field Parameters, Major and Trace Elements, and Nutrients ...................................39

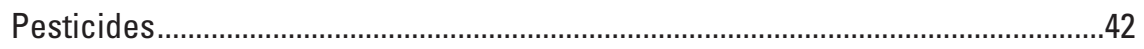

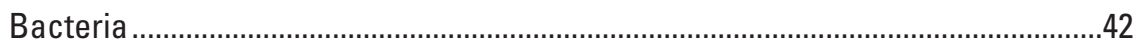

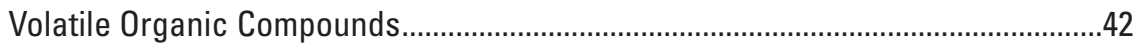

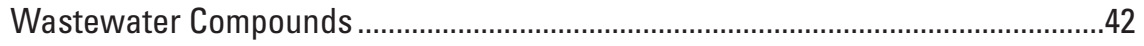

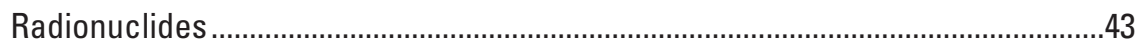

Water-Quality Results in Relation to Drinking-Water Standards............................43

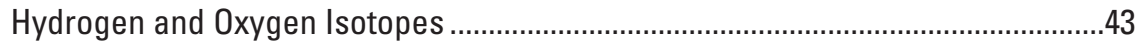

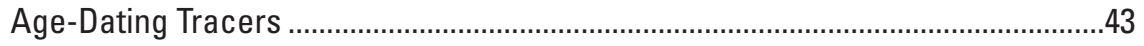

Status of Current Data Collection and Focus for Future Work ............................................53

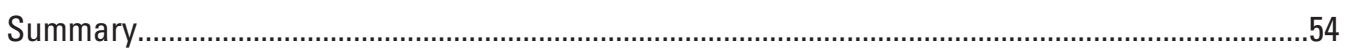

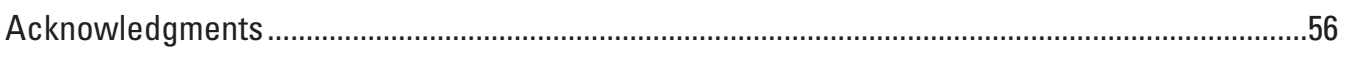

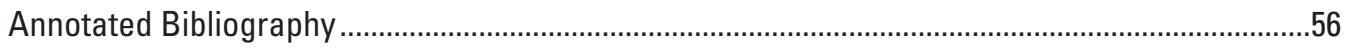

Appendix 1. Summary of Literature Review for the Tuscarawas River Basin..............................102

Appendix 2. Results of Analyses of Water Samples Collected within the

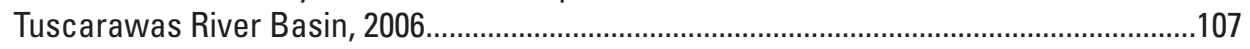

Appendix 3. Glossary of Water-Quality Reporting Levels and Qualifiers ....................................115

\section{Plate}

[In pocket]

1. Estimated water levels in the bedrock/unconsolidated aquifers in and around the Tuscarawas River Basin, Ohio

\section{Figures}

1-7. Maps showing:

1. The Tuscarawas River Basin, Ohio ......................................................................

2. Ecoregions in and around the Tuscarawas River Basin, Ohio ...................................5

3. Land-surface topography in and around the

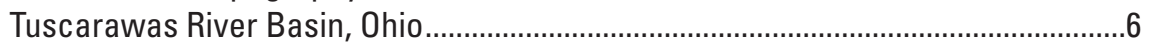

4. Generalized soil regions in the Tuscarawas River Basin, Ohio ...............................7

5. Population of townships in and around the Tuscarawas River Basin, Ohio, 2000 .................................................................

6. Generalized land use in and around the Tuscarawas River Basin, Ohio, 2001

7. Generalized bedrock geology in and around the Tuscarawas River Basin, Ohio

8. Generalized stratigraphic section of rocks within 300 feet of the surface in the Tuscarawas River Basin, Ohio. 
9-15. Maps showing:

9. Unconsolidated surficial sediments in and around the Tuscarawas River Basin, Ohio.

10. Locations of mining operations in and around the Tuscarawas River Basin, Ohio.

11. Percentages of groundwater and surface-water use for 1985, 1990, 1995, and 2000 in and around the Tuscarawas River Basin, Ohio . .24

12. Locations of meteorological stations in and around the Tuscarawas River Basin, Ohio

13. Locations of surface-water data-collection sites in and around the Tuscarawas River Basin, Ohio

14. Locations of groundwater data-collection sites in and around the Tuscarawas River Basin, Ohio.....

15. Locations of water-quality data-collection sites in and around the Tuscarawas River Basin, Ohio.

16. Piper diagram of water quality in samples collected in the Tuscarawas River Basin, Ohio, 2006.

17. Graph showing relation between oxygen $\left(\delta^{18} 0\right)$ and deuterium $(\delta D)$

isotope ratios in water samples from the Tuscarawas River Basin, Ohio

\section{Tables}

1. Population of counties that encompass the Tuscarawas River Basin, Ohio, 1980, 1990, 2000, and 2006

2. Land use in and around the Tuscarawas River Basin, Ohio,

$(A)$ as percentage of basin area, and $(B)$ as percentage of county area, 1992 and 2001

3. Source Water Assessment and Protection Program areas by county within the Tuscarawas River Basin, Ohio, on record with the Ohio Environmental Protection Agency as of 2009

4 Estimated total water use by water-use category in the counties that encompass the Tuscarawas River Basin, Ohio, 2000

5. Estimated groundwater and surface-water use for the Tuscarawas River Basin, Ohio, 1985-2000 . .26

6. Watershed groups in the Tuscarawas River Basin, Ohio .31

7. Description of groundwater and surface-water sites sampled in the Tuscarawas River Basin, Ohio, July and August, 2006

8. Land use surrounding sampling sites in the Tuscarawas River Basin, Ohio .39

9. Land-use changes between 1992 and 2006 for sampling sites in the Tuscarawas River Basin, Ohio

10. Pesticides analyzed in groundwater and surface-water samples from the Tuscarawas River Basin, Ohio, 2006

11. Pesticides present in surface-water samples from the Tuscarawas River Basin, Ohio, 2006.

12. Volatile organic compounds analyzed in groundwater and surface-water samples from the Tuscarawas River Basin, Ohio, 2006

13. Wastewater compounds analyzed in groundwater and surface-water samples from the Tuscarawas River Basin, Ohio, 2006 
14. Wastewater compounds detected in groundwater and surface-water samples from the Tuscarawas River Basin, Ohio, 2006

15. Exceedances of Secondary Maximum Contaminant Levels (SMCLs) in groundwater and surface-water samples from the Tuscarawas River Basin, Ohio, 2006

\section{Conversion Factors, Datums, and Abbreviations}

\begin{tabular}{|c|c|c|}
\hline Multiply & By & To obtain \\
\hline \multicolumn{3}{|c|}{ Length } \\
\hline inch (in.) & 2.54 & centimeter $(\mathrm{cm})$ \\
\hline inch (in.) & 25.4 & millimeter (mm) \\
\hline foot (ft) & .3048 & meter $(\mathrm{m})$ \\
\hline mile (mi) & 1.609 & kilometer $(\mathrm{km})$ \\
\hline \multicolumn{3}{|c|}{ Area } \\
\hline acre & 4,047 & square meter $\left(\mathrm{m}^{2}\right)$ \\
\hline acre & .4047 & hectare (ha) \\
\hline square foot $\left(\mathrm{ft}^{2}\right)$ & 929.0 & square centimeter $\left(\mathrm{cm}^{2}\right)$ \\
\hline square foot $\left(\mathrm{ft}^{2}\right)$ & .09290 & square meter $\left(\mathrm{m}^{2}\right)$ \\
\hline square mile $\left(\mathrm{mi}^{2}\right)$ & 2.590 & square kilometer $\left(\mathrm{km}^{2}\right)$ \\
\hline \multicolumn{3}{|c|}{ Volume } \\
\hline gallon (gal) & 3.785 & liter (L) \\
\hline gallon (gal) & .003785 & cubic meter $\left(\mathrm{m}^{3}\right)$ \\
\hline million gallons (Mgal) & 3,785 & cubic meter $\left(\mathrm{m}^{3}\right)$ \\
\hline \multicolumn{3}{|c|}{ Flow rate } \\
\hline foot per day (ft/d) & .3048 & meter per day $(\mathrm{m} / \mathrm{d})$ \\
\hline cubic foot per second $\left(\mathrm{ft}^{3} / \mathrm{s}\right)$ & .02832 & cubic meter per second $\left(\mathrm{m}^{3} / \mathrm{s}\right)$ \\
\hline gallon per minute (gal/min) & .06309 & liter per second $(\mathrm{L} / \mathrm{s})$ \\
\hline inch per year (in/yr) & 25.4 & millimeter per year (mm/yr) \\
\hline \multicolumn{3}{|c|}{ Mass } \\
\hline ton, short $(2,000 \mathrm{lb})$ & .9072 & megagram (Mg) \\
\hline ton, long $(2,240 \mathrm{lb})$ & 1.016 & megagram $(\mathrm{Mg})$ \\
\hline \multicolumn{3}{|c|}{ Radioactivity } \\
\hline picocurie per liter $(\mathrm{pCi} / \mathrm{L})$ & .037 & becquerel per liter $(\mathrm{Bq} / \mathrm{L})$ \\
\hline \multicolumn{3}{|c|}{ Hydraulic conductivity } \\
\hline foot per day (ft/d) & .3048 & meter per day $(\mathrm{m} / \mathrm{d})$ \\
\hline $\mathrm{gal} / \mathrm{d} / \mathrm{ft}^{2}$ & .000472 & centimeter per second $(\mathrm{cm} / \mathrm{s})$ \\
\hline \multicolumn{3}{|c|}{ Transmissivity* } \\
\hline foot squared per day $\left(\mathrm{ft}^{2} / \mathrm{d}\right)$ & .09290 & meter squared per day $\left(\mathrm{m}^{2} / \mathrm{d}\right)$ \\
\hline gallon per day per foot (gal/d/ft) & .000472 & centimeter squared per second $\left(\mathrm{cm}^{2} / \mathrm{s}\right)$ \\
\hline
\end{tabular}


Temperature in degrees Celsius $\left({ }^{\circ} \mathrm{C}\right.$ or $\left.\operatorname{deg} \mathrm{C}\right)$ may be converted to degrees Fahrenheit $\left({ }^{\circ} \mathrm{F}\right.$ or $\operatorname{deg}$ F) as follows:

${ }^{\circ} \mathrm{F}=\left(1.8 \times^{\circ} \mathrm{C}\right)+32$

Temperature in degrees Fahrenheit ( ${ }^{\circ} \mathrm{F}$ or deg F) may be converted to degrees Celsius $\left({ }^{\circ} \mathrm{C}\right.$ or $\operatorname{deg} \mathrm{C})$ as follows:

${ }^{\circ} \mathrm{C}=\left({ }^{\circ} \mathrm{F}-32\right) / 1.8$

Vertical coordinate information is referenced to the North American Vertical Datum of 1988 (NAVD 88).

Horizontal coordinate information is referenced to North American Datum of 1983 (NAD 83).

Altitude, as used in this report, refers to distance above the vertical datum.

*Transmissivity: The standard unit for transmissivity is cubic foot per day per square foot times foot of aquifer thickness $\left[\left(\mathrm{ft}^{3} / \mathrm{d}\right) / \mathrm{ft}^{2}\right] \mathrm{ft}$. In this report, the mathematically reduced form, foot squared per day $\left(\mathrm{ft}^{2} / \mathrm{d}\right)$, is used for convenience. Gallon per day per foot $(\mathrm{gal} / \mathrm{d} / \mathrm{ft})$ also is used in publications cited in this report and is included for reference and comparison between publications.

Specific conductance is given in microsiemens per centimeter at 25 degrees Celsius $(\mu \mathrm{S} / \mathrm{cm}$ at $\left.25^{\circ} \mathrm{C}\right)$.

Concentrations of chemical constituents in water are given in milligrams per liter (mg/L), micrograms per liter $(\mu \mathrm{g} / \mathrm{L})$, femtograms per kilogram $(\mathrm{fg} / \mathrm{kg})$, micrograms per kilogram $(\mu \mathrm{g} / \mathrm{kg})$, or picograms per kilogram $(\mathrm{pg} / \mathrm{kg})$. 



\title{
Summary of Hydrologic Data for the Tuscarawas River Basin, Ohio, with an Annotated Bibliography
}

\author{
By Ralph J. Haefner and Laura A. Simonson
}

\section{Abstract}

The Tuscarawas River Basin drains approximately 2,600 square miles in eastern Ohio and is home to 600,000 residents that rely on the water resources of the basin. This report summarizes the hydrologic conditions in the basin, describes over 400 publications related to the many factors that affect the groundwater and surface-water resources, and presents new water-quality information and a new water-level map designed to provide decisionmakers with information to assist in future data-collection efforts and land-use decisions.

The Tuscarawas River is 130 miles long, and the drainage basin includes four major tributary basins and seven man-made reservoirs designed primarily for flood control. The basin lies within two physiographic provinces - the Glaciated Appalachian Plateaus to the north and the unglaciated Allegheny Plateaus to the south. Topography, soil types, surficial geology, and the overall hydrology of the basin were strongly affected by glaciation, which covered the northern one-third of the basin over 10,000 years ago. Within the glaciated region, unconsolidated glacial deposits, which are predominantly clay-rich till, overlie gently sloping Pennsylvanian-age sandstone, limestone, coal, and shale bedrock. Stream valleys throughout the basin are filled with sands and gravels derived from glacial outwash and alluvial processes. The southern two-thirds of the basin is characterized by similar bedrock units; however, till is absent and topographic relief is greater. The primary aquifers are sand- and gravel-filled valleys and sandstone bedrock. These sands and gravels are part of a complex system of aquifers that may exceed 400 feet in thickness and fill glacially incised valleys. Sand and gravel aquifers in this basin are capable of supporting sustained well yields exceeding 1,000 gallons per minute. Underlying sandstones within 300 feet of the surface also provide substantial quantities of water, with typical well yields of up to 100 gallons per minute. Although hydraulic connection between the sandstone bedrock and the sands and gravels in valleys is likely, it has not been assessed in the Tuscarawas River Basin.

In 2001, the major land uses in the basin were approximately 40 percent forested, 39 percent agricultural, and 17 percent urban/residential. Between 1992 and 2001, forested land use decreased by 2 percent with correspondingly small increases in agricultural and urban land uses, but from 1980 to 2005 , the 13-county area that encompasses the basin experienced a 7.1-percent increase in population. Higher population density and percentages of urban land use were typical of the northern, headwaters parts of the basin in and around the cities of Akron, Canton, and New Philadelphia; the southern area was rural.

The basin receives approximately 38 inches of precipitation per year that exits the basin through evapotranspiration, streamflow, and groundwater withdrawals. Recharge to groundwater is estimated to range from 6 to 10 inches per year across the basin. In 2000, approximately 89 percent of the 116 million gallons per day of water used in the basin came from groundwater sources, whereas 11 percent came from surfacewater sources. To examine directions of groundwater flow in the basin, a new dataset of water-level contours was developed by the Ohio Department of Natural Resources. The contours were compiled on a map that shows that groundwater flows from the uplands towards the valleys and that the water-level surface mimics surface topography; however, there are areas where data were too sparse to adequately map the water-level surface. Additionally, little is known about deep groundwater that may be flowing into the basin from outside the basin and groundwater interactions with surface-water bodies.

Many previous reports as well as new data collected as part of this study show that water quality in the streams and aquifers in the Tuscarawas River Basin has been degraded by urban, suburban, and rural agricultural activity, discharges from municipal and industrial wastewater treatment and thermoelectric power plants, mining, and disposal of solid and hazardous wastes. Environmental effects from mining coal during the 1800 s through the mid- to late-1900s continue to affect water quality and aquatic habitat in the basin.

As part of this study, seven groundwater samples and two surface-water samples were collected and analyzed for a wide variety of constituents. Several samples exceeded the U.S. Environmental Protection Agency Secondary Maximum Contaminant Levels for $\mathrm{pH}$, iron, manganese, sulfate, and (or) residue on evaporation. Most of the analyses for pesticides, volatile organic compounds, and fecal indicator bacteria resulted in concentrations at or below detection limits; however, surface-water samples typically had more detections of 
these constituents than did groundwater. Wastewater compounds derived from urban wastewater discharges (including septic systems) were detected in only one of seven groundwater samples. Fecal coliform bacteria and E. Coli were detected in this same groundwater sample, indicating that this sample may have been affected by a nearby septic system. Analysis of age-dating tracers in the seven groundwater samples, including chlorofluorocarbons, tritium/helium, and sulfur hexafluoride, indicated that the average residence time of shallow groundwater was less than 50 years, confirming that shallow groundwater is relatively young and its quality is susceptible to contamination from current land-use practices. Tritium/helium and sulfur hexafluoride offer the best age-dating tools in this setting because the data indicate that chlorofluorocarbons were likely degraded under anoxic conditions.

As of 2009, a multitude of weather stations, 17 streamgages, 6 water-quality monitors, and 27 observation wells that monitor local hydrologic conditions were operating in and around the basin. Substantial historical water-quality data from surface-water and groundwater sites that were sampled on rotating schedules by other agencies provide a basis for analyzing trends in water quality. The data are consistent with the results of water-quality analyses obtained in this study; however, monitoring data collected during extreme events such as floods and droughts are lacking. To support future land-use decisions and document the influences of land-use change (which might include, for example, zoning, stormwater best management practices, and mine reclamation), additional continuously collected data would be needed to understand short- and long-term temporal changes in water quality.

\section{Introduction}

The Tuscarawas River Basin in eastern Ohio provides water to almost 600,000 people (U.S. Census Bureau, 2008) and is home to agricultural, mining, and industrial activities. The Cities of Akron, Canton, Wooster, New Philadelphia, Coshocton (fig. 1), and numerous smaller towns and communities rely on the abundant water resources of the basin for their economic and population growth. Census data for 1980 and 2006 show population growth of approximately 7.1 percent within counties that lie within or partly within the basin (U.S. Census Bureau, 2008). Although the overall water use has decreased from approximately $185 \mathrm{Mgal} / \mathrm{d}$ in 1985 to $119 \mathrm{Mgal} / \mathrm{d}$ in 2000 , the percentage of water derived from groundwater sources has increased from 55 to 89 percent of the total withdrawals during this period because of a reduction in industrial surface-water uses (Hutson and others, 2004). Thus, pressures of development and changes in groundwater and surface-water uses are altering the stresses on the heavily utilized water resources of the basin.
This study was conducted by the U.S. Geological Survey (USGS), in cooperation with the Stark-Tuscarawas-Wayne Joint Solid Waste Management District, to provide decisionmakers with land-use and water-resources data and acquaint them with the broad spectrum of hydrologic information available on the basin. The purpose of this report is to summarize existing information regarding the geology, hydrology, and water quality in and around the Tuscarawas River Basin. The report includes a literature review and a summary of the hydrologic data available throughout the basin. Hydrologic data are evaluated in terms of spatial and temporal distribution to provide decisionmakers with information that may be required to make future data-collection and land-use decisions; however, only a small amount of the actual data are included in this report. In addition, water-quality data collected as part of this study in 2006 at two stream sites on the Tuscarawas River and at seven groundwater sites located across the basin are evaluated in relation to land use.

The scope of this report is limited to hydrologic information available as of 2009 for the Tuscarawas River Basin and parts of adjoining basins that have similar hydrogeologic settings. Reports and datasets described in this report varied in scale and extent (for example, township, county, subbasin, or region), and only minimal attempts were made to redefine the extent of these data based on basin boundaries or other boundaries. Therefore, the text, figures, and tables in this report often include information from geographic areas adjacent to the Tuscarawas River Basin (usually within 10 miles of the basin boundary). This additional information may help the reader more clearly evaluate data that may be relevant to understanding the hydrology of the Tuscarawas River Basin.

\section{Literature Review}

Many studies have been done on different aspects of the geology, hydrology, water quality, and water use in and around the Tuscarawas River Basin. To gain a better understanding of these studies, a literature review was completed through library and Internet searches. The focus of this review was on water resources, sustainability, and other information that may be needed by decisionmakers to ensure the long-term viability of the water resources in the basin. Approximately 400 references from published reports, maps, digital and hard- copy datasets, and World Wide Web sites were compiled during this review. Most of the references are cited in the sections below, along with supporting information in the Annotated Bibliography. Additionally, these references are categorized in appendix 1 under topical headings to provide readers with a means of quickly obtaining references that pertain to a particular waterresources topic. Many of the references are listed more than once because they contain information on multiple topics. 


\section{General Basin Characteristics}

The Tuscarawas River Basin covers approximately 2,600 square miles within 13 counties in eastern Ohio, specifically Belmont, Carroll, Columbiana, Coshocton, Guernsey, Harrison, Holmes, Medina, Portage, Stark, Summit, Tuscarawas, and Wayne County (fig. 1). The Tuscarawas River is 129.9 miles long. The headwaters are to the north and east of the Portage Lakes in northern Stark, Summit, and Medina Counties. The river flows south to Newcomerstown, then westward from Newcomerstown to Coshocton. In Coshocton, the river joins the Walhonding River to form the Muskingum River, which flows southward to the Ohio River shown on the inset map on figure 1. According to the U.S. Geological Survey Geographic Names Information System (U.S. Geological Survey, 2008a), the Tuscarawas River also has been known by the names Little Muskingum River, Mashongam River, Tuscarawa River, and Tuskarawas Creek. The word Tuscarawas was likely derived from the Native American capital at Bolivar, also known as Tuscarawas Town or Tuscarora (Heritage Pursuit, 2009). The name reportedly originates from the Tuscarora tribe of Native Americans, who occupied this region, and has been defined as "open mouth" or "old town" (Old Town was the name of the ancient Indian town opposite the mouth of Sandy Creek).

\section{Physiographic Provinces}

As defined by Fenneman (1938), the Tuscarawas River Basin lies within two physiographic regions: the Glaciated Appalachian Plateaus to the north and the unglaciated Allegheny Plateaus to the south (fig. 2). The glaciated portion is characterized by gently rolling hills, whereas the unglaciated portion has much steeper topography with higher hilltops and deeper valleys. Ecoregions (areas of general similarity in the type, quality, and quantity of environmental resources) developed by Omernick (1987) and later refined by Woods and others (1998) within the basin are similar to the physiographic regions/provinces. Parts of two primary ecoregions, the Erie Drift Plains and the Erie Gorges, are within the Tuscarawas River Basin. The Erie Drift Plains, which includes the Low Lime Drift Plain, the Summit Interlobate Area, and the Erie Gorges (shown in shades of green in figure 2) are characterized by low rounded hills, scattered end moraines, kettles, and areas of wetlands. The Western Allegheny Plateau, which includes the Unglaciated Upper Muskingum Basin, the Pittsburgh Low Plateau, and the Monongahela Transition Zone (shown in shades of blue on fig. 2) is characterized by hilly and wooded terrain.

\section{Climate}

Climate within the basin is generally temperate with cold winters and warm, humid summers. Temperature and rainfall data compiled from 18 stations within the basin for the period 1970 to 2000 (National Oceanic and Atmospheric
Administration, 2002) indicate that mean annual temperature was $50.1 \mathrm{deg} \mathrm{F}(10.0 \operatorname{deg} \mathrm{C})$ with mean maximum and minimum monthly temperatures of $72 \mathrm{deg} F(22.2 \mathrm{deg} C$ ) in July and $26 \operatorname{deg}$ F (-3.3 deg C) in January. Mean annual rainfall was 38.7 inches with the maximum monthly mean rainfall occurring in July (4.1 inches) and the minimum monthly mean temperature occurring in February (2.2 inches). Lake-effect weather from Lake Erie in the northern part of basin causes increased snowfall, winter cloudiness, and length of growing season relative to the rest of the basin.

\section{Elevation and Topography}

Elevation ranges from about $820 \mathrm{ft}(250 \mathrm{~m})$ above mean sea level (North American Vertical Datum of 1988) near Coshocton to about $1,400 \mathrm{ft}(427 \mathrm{~m})$ in the uplands near the outer edges of the basin (fig. 3). Glaciation probably had the greatest effect on the topography of the northern part of the basin, whereas stream erosion and sedimentation likely had the greatest effect on the southern part. As noted in the description of physiography and ecoregions, the northern, glaciated part of the basin has rolling hills with moderate changes in topography, whereas the southern, unglaciated part of the basin has steeper slopes.

\section{Soils}

Information on soils was compiled from county and regional maps published by the Natural Resources Conservation Service (1998a, 1998b, 2002, and 2005), formerly known as the U.S. Soil Conservation Service (1967, 1971, 1977, 1978, 1981, 1983, 1984, 1986, and 1990). The soil regions shown in figure 4 were generalized by drainage characteristics and parent materials and reflect the basin's glacial history (R.M. Gehring, U.S. Department of Agriculture, Natural Resources Conservations Service, written commun., 2008). Soils in the Tuscarawas River Basin are characterized by poorly to well-drained soils formed on till plains to the north of the glacial boundary and well-drained soils on sandstone and shale parent material over the southern part of the basin. Throughout the entire basin, poorly to well-drained soils in lacustrine (lake) sediments and alluvium are typical in the river valleys (shaded dark green on figure 4). Soils in the northern area are low in organic matter and are acidic. The soils generally are low in fertility, and the primary agriculture in this region involves farming and dairy operations. Soils in the southern, unglaciated area also are acidic and often are low in organic matter and natural fertility. Because the unglaciated area has greater relief than the glaciated areas, steep hillsides and narrow ridges lead to rapid runoff and erosion. Therefore, much of the land in this region is too hilly or the soils are too shallow for farming, resulting in land usually consisting of pasture or forest. In general, crops are grown on more gentle slopes or within the floodplains, which can be up to $1.5 \mathrm{mi}$ wide along the Tuscarawas River between New Philadelphia and Coshocton. 


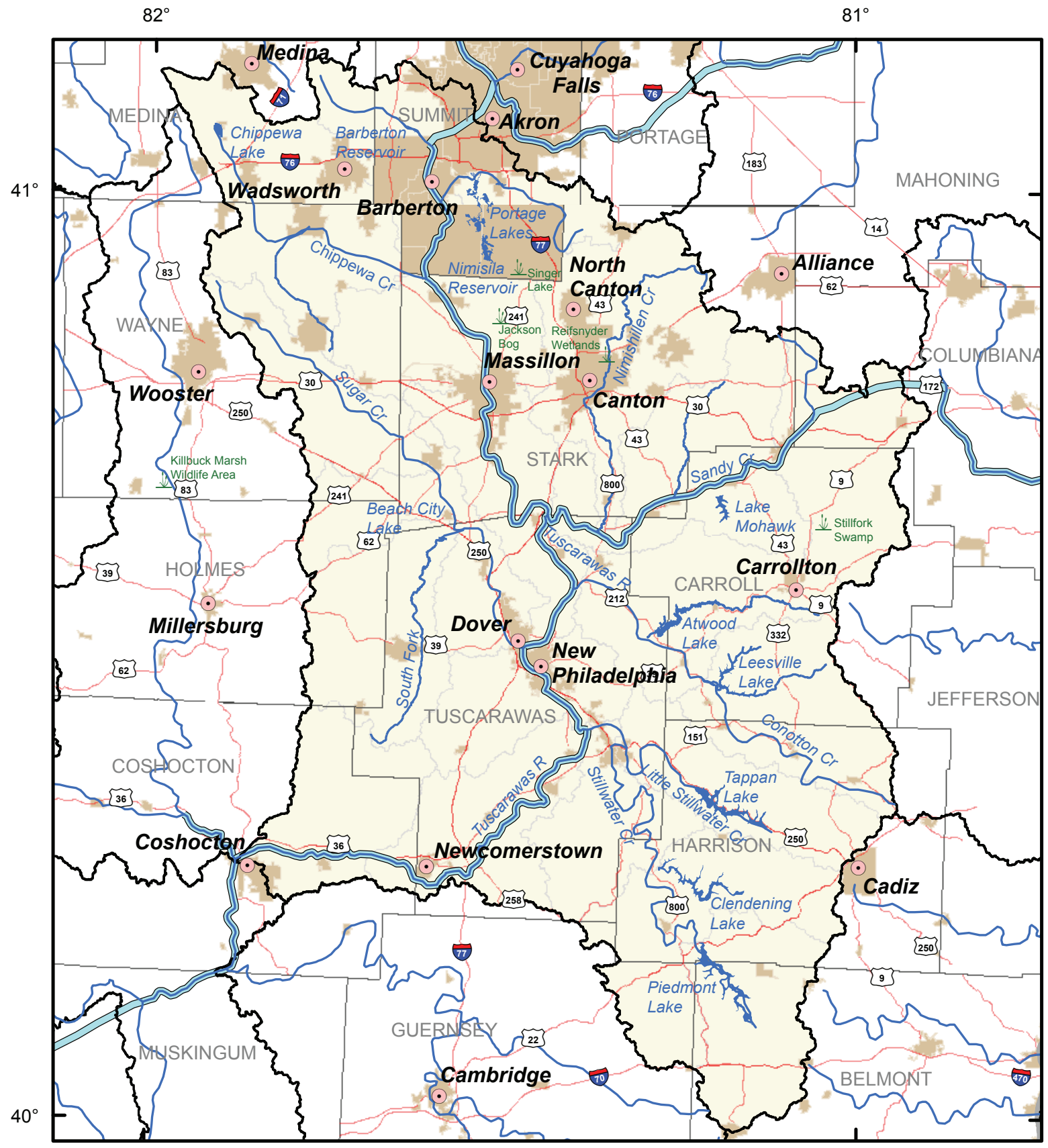

Base from Natural Resources Conservation Service, 1999; scale 1:24,000; North American Datum, 1983.
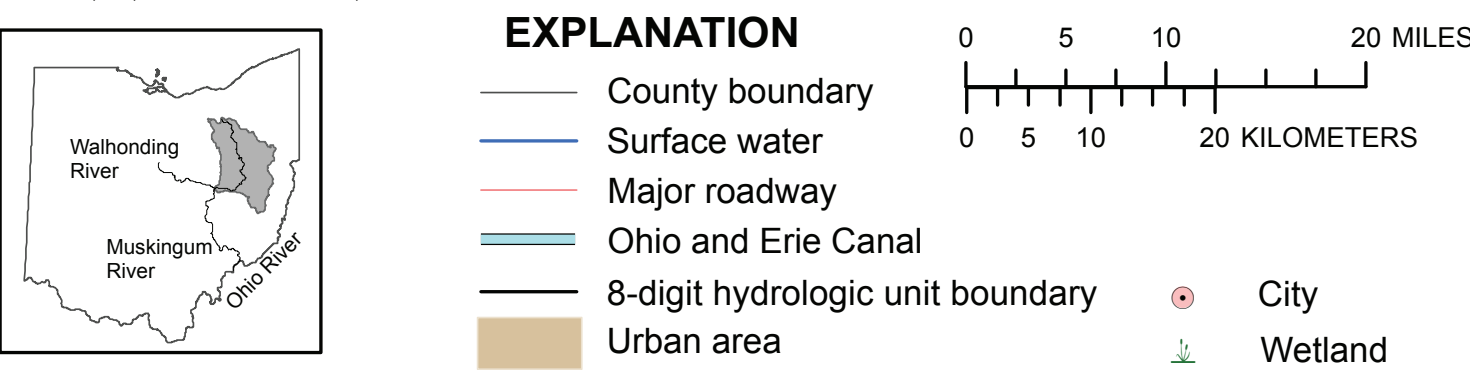

Figure 1. The Tuscarawas River Basin, Ohio. 


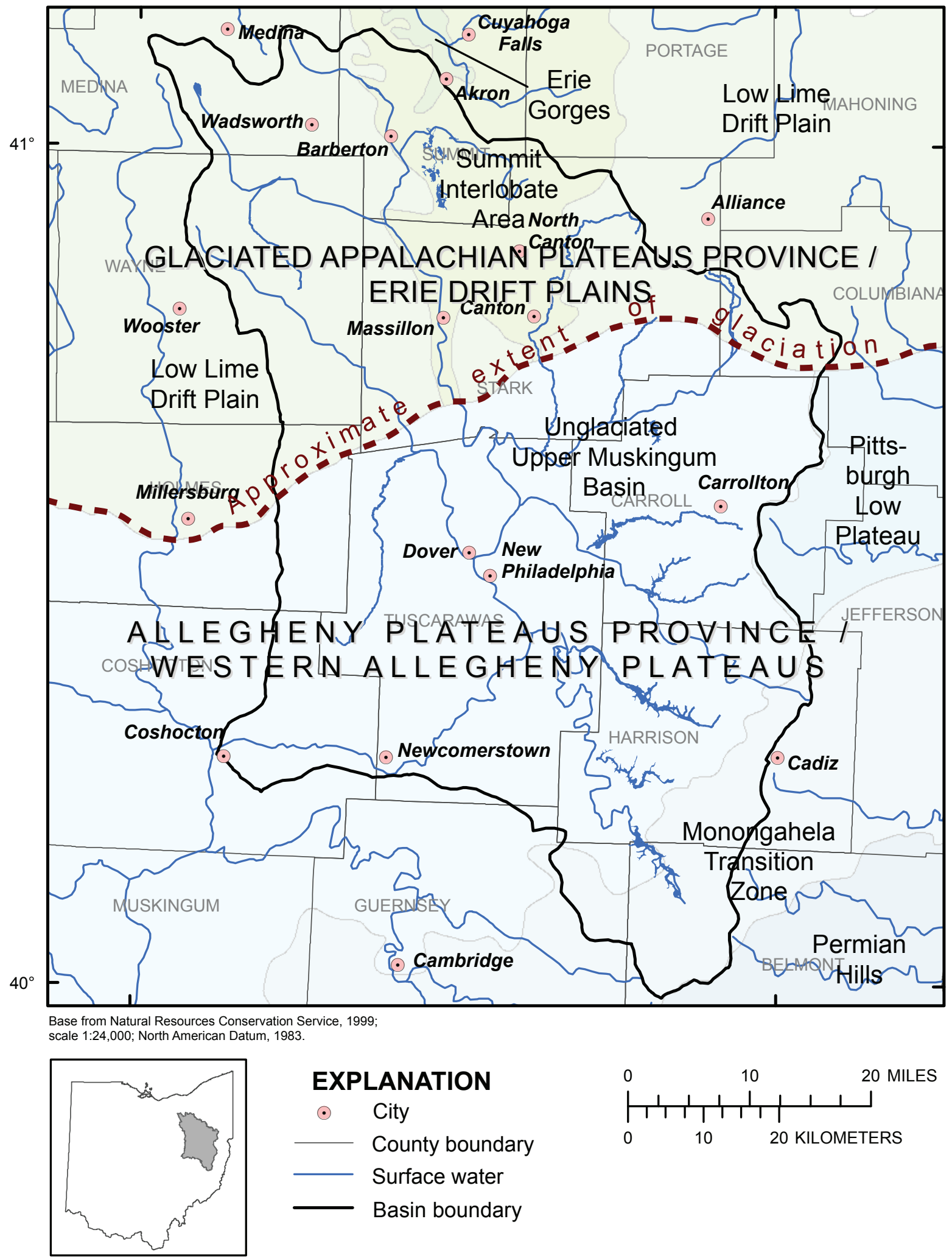

Figure 2. Ecoregions in and around the Tuscarawas River Basin, Ohio. (Modified from Fenneman, 1938; Wood and others, 1998) 


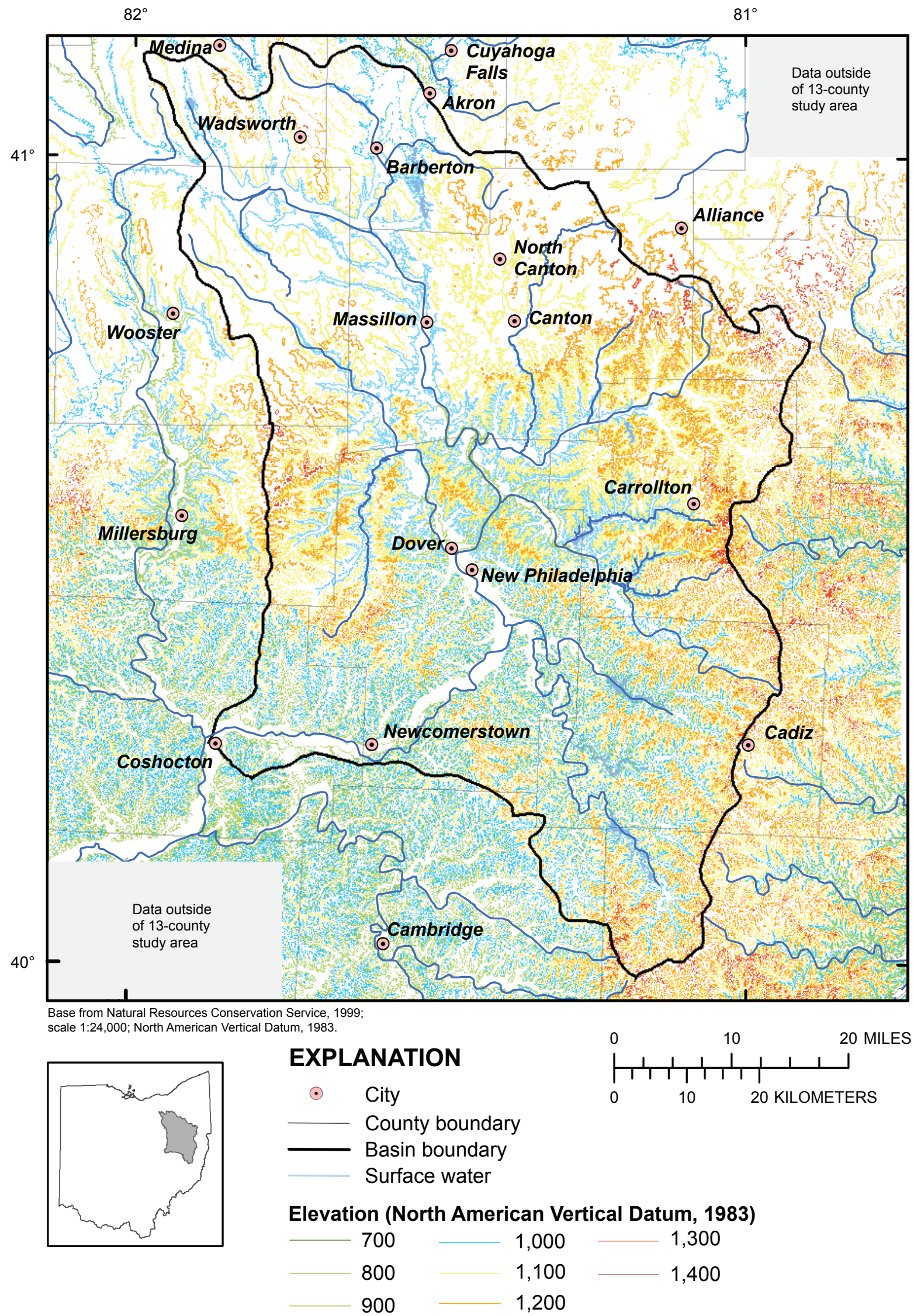

Figure 3. Land-surface topography in and around the Tuscarawas River Basin, Ohio. (From U.S. Geological Survey, 1981) 


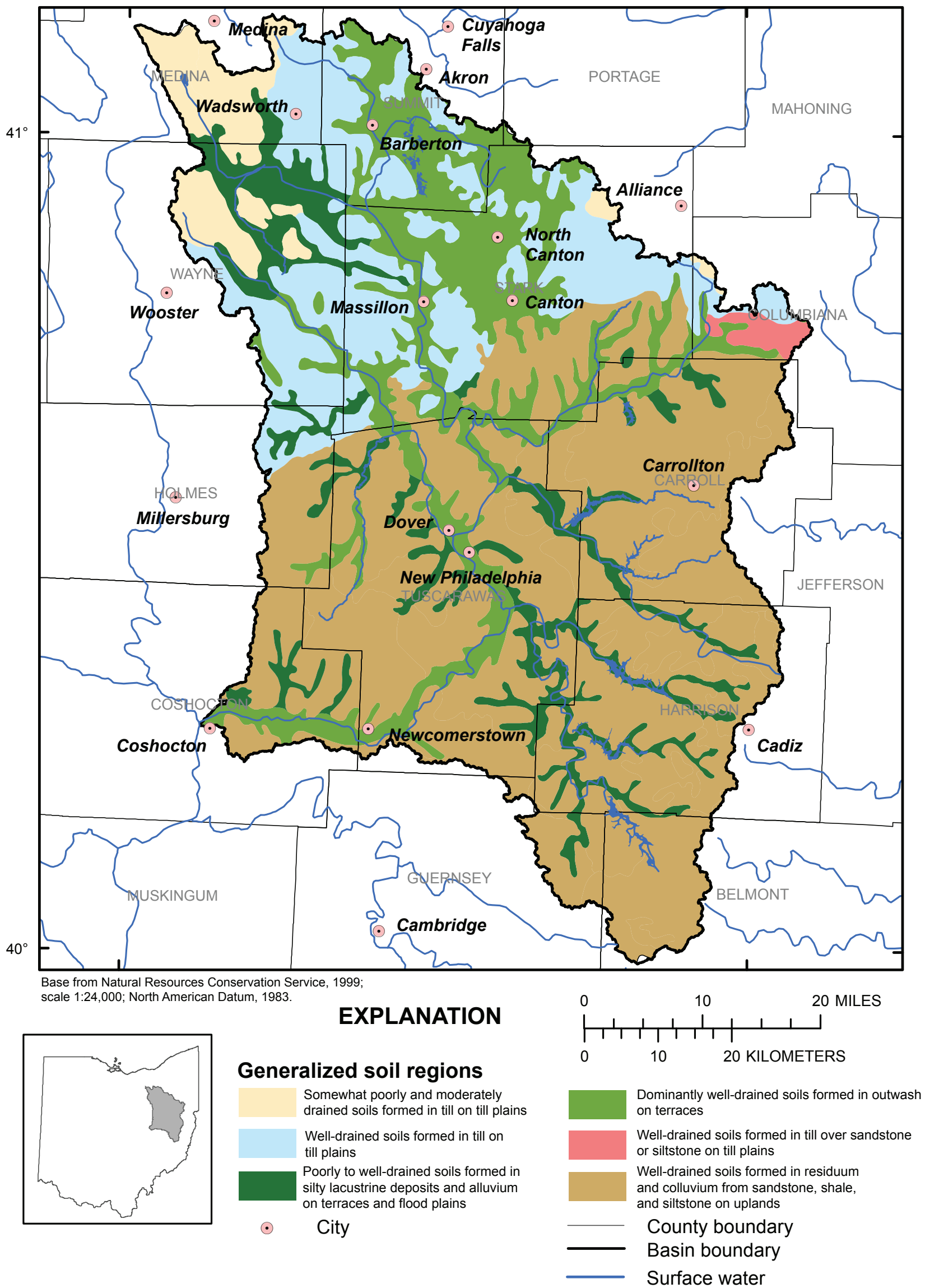

Figure 4. Generalized soil regions in the Tuscarawas River Basin, Ohio. (Modified from R.M. Gehring, Natural Resources Conservation Service, written commun., 2008) 


\section{Population}

Population estimated by the U.S. Census Bureau (2008) for the Tuscarawas River Basin in 2006 was approximately 600,000 ; however, population within the 13 counties that encompass the Tuscarawas River Basin was approximately 1.8 million (table 1). The estimate for the entire 13-county area is much larger than that of the basin itself and reflects the fact that many high-density residential areas are in close proximity to the basin.

The northern, headwaters areas of the basin are the most densely populated part of the basin (fig. 5). Stark and Summit Counties had estimated populations of 380,575 and 545,931 in 2006, respectively, with the greatest density centered on the city of Akron, which is only partly within the basin (table 1). Approximately 51 percent of the total population in the basin resides in Summit and Stark Counties, yet these counties make up only 26 percent of the basin land area. Akron had an estimated 210,795 residents in 2006 (U.S. Census Bureau, 2008). Portage and Medina Counties also were relatively heavily populated with estimated populations of 155,012 and
169,353 , respectively. Wayne and Columbiana Counties were the only other counties in the basin with populations greater than 100,000 . In addition to Akron, major urban areas in the basin with estimated populations greater than 25,000 in 2006 include Canton, Massillon, and Medina, all of which are located in the northern half of the basin (U.S. Census Bureau, 2008). Thus, the population distribution in the Tuscarawas River Basin is unlike many other basins in Ohio, including the Maumee and Great Miami River Basins, in that the Tuscarawas has the greatest population density in the headwaters area, whereas other basins have the greatest population densities in the lowland areas, towards the river mouths.

From 1980 to 2006, the overall population for the 13 counties that encompass the Tuscarawas River Basin increased by 7.1 percent (table 1). In the northern and western parts of the basin, Medina and Holmes Counties had the largest population increase at 49.7 and 41.3 percent, respectively. In contrast, population in counties in the southern part of the basin, including Harrison and Belmont Counties, decreased by 13.0 and 16.7 percent, respectively.

Table 1. Population of counties that encompass the Tuscarawas River Basin, Ohio, 1980, 1990, 2000, and 2006.

[From U.S. Census Bureau, 2008]

\begin{tabular}{lrrrrc}
\hline \multicolumn{1}{c}{ County } & $\mathbf{1 9 8 0}$ & $\mathbf{1 9 9 0}$ & $\mathbf{2 0 0 0}$ & $\begin{array}{c}\text { Estimated } \\
\mathbf{2 0 0 6}\end{array}$ & $\begin{array}{c}\text { Change from } \\
\mathbf{1 9 8 0} \text { to 2006 } \\
\text { (percent) }\end{array}$ \\
\hline Belmont & 82,569 & 71,074 & 70,226 & 68,771 & -16.7 \\
Carroll & 25,598 & 26,521 & 28,836 & 29,189 & 14.0 \\
Columbiana & 113,572 & 108,276 & 112,075 & 110,542 & -2.7 \\
Coshocton & 36,024 & 35,427 & 36,655 & 36,976 & 2.6 \\
Guernsey & 42,024 & 39,024 & 40,792 & 40,876 & -2.7 \\
Harrison & 18,152 & 16,085 & 15,856 & 15,799 & -13.0 \\
Holmes & 29,416 & 32,849 & 38,943 & 41,574 & 41.3 \\
Medina & 113,150 & 122,354 & 151,095 & 169,353 & 49.7 \\
Portage & 135,856 & 142,585 & 152,061 & 155,012 & 14.1 \\
Stark & 378,823 & 367,585 & 378,098 & 380,575 & .5 \\
Summit & 524,472 & 514,990 & 542,899 & 545,931 & 4.1 \\
Tuscarawas & 84,614 & 84,090 & 90,914 & 91,766 & 8.5 \\
Wayne & 97,408 & 101,461 & 111,564 & 113,950 & 17.0 \\
Total & $\mathbf{1 , 6 8 1 , 6 7 8}$ & $\mathbf{1 , 6 6 2 , 3 2 1}$ & $\mathbf{1 , 7 7 0 , 0 1 4}$ & $\mathbf{1 , 8 0 0 , 3 1 4}$ & $\mathbf{7 . 1}$ \\
\hline
\end{tabular}




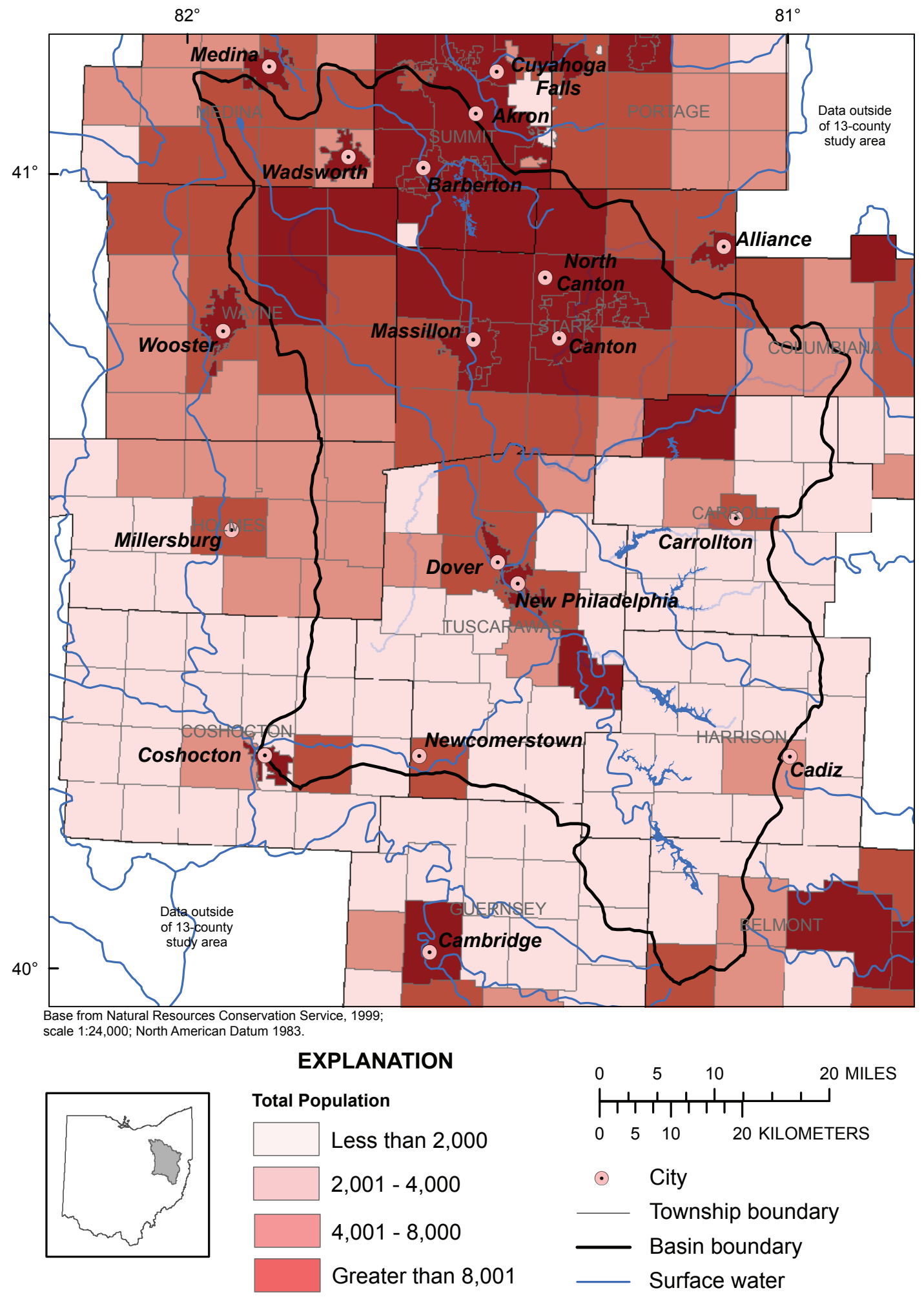

Figure 5. Population of townships in and around the Tuscarawas River Basin, Ohio, 2000. (U.S. Census Bureau, 2008) 


\section{Land Use}

Land use throughout Ohio has been evaluated using different techniques serving different purposes (for this study, the terms land use and land cover are used interchangeably). An early land-use assessment was done by Morse (1939), who examined erosion related to land-use conditions in the Muskingum River Basin. (As noted above, the Tuscarawas River is part of the Muskingum River drainage basin.) Wright (1953) described the economic geography of Ohio and noted the abundance of natural resources, including water and mineral commodities. The first state-wide land-use classification was done as part of the Ohio Capability Analysis Program (OCAP) initiated by the Ohio Department of Natural Resources in 1972. OCAP was created to produce a natural-resources inventory of Ohio, including soils, land use, water resources, and geology, to provide technical-resource information for people at the local level who make land-use decisions (Gordon, 1978; Vertrees, 1985). Analyses of OCAP data were done by Maxson (1975) for Stark County and by Ondecko and Schultz (1981) for Portage County.

As the focus on environmental issues increased in the mid-1970s, Groenewold (1974), Van Horn (1976), and Hull (1984) examined environmental conditions in Stark, Portage, and Summit Counties, respectively, for suitable locations for solid-waste disposal facilities from a geologic perspective. All three authors concluded that upland areas where thick layers of relatively impermeable glacial till overlie shale or clay provide the best locations for new solid-waste disposal facilities. The authors also stated that areas on floodplains above highly permeable sands and gravels associated with glacial and (or) alluvial deposits should be avoided for these purposes.

Several entities in the Tuscarawas River Basin have published watershed plans that include different aspects of landuse data. The Stark County Regional Planning Commission (1997) and the Stark County Regional Planning Commission and Stark County Area Transportation Study (2005) developed land-use plans through the year 2020 and identified water resources that relate to stormwater, solid-waste disposal, and central sewer and water services as major issues. The Northeast Ohio Four County Regional Planning and Development Organization published watershed action plans for Portage, Stark, Summit, and Wayne Counties (Northeast Ohio Four County Regional Planning and Development Organization, $1975,1985)$ along with water-resource inventories, watershed assessments, and management plans for the Upper Tuscarawas River Basin (Northeast Ohio Four County Regional Planning and Development Organization, 1999a, 1999b, 2004), Upper Wolf Creek (Northeast Ohio Four County Regional Planning and Development Organization, 1999c), and Nimishillen Creek (Northeast Ohio Four County Regional Planning and Development Organization, 2001b; Akin, 2006). Each of the Northeast Ohio Four County Regional Planning and Development Organization publications provided land-use analyses relative to their potential effects on water resources. The Wayne County Comprehensive Plan (Wayne County
Planning Department, 2006) recommends constraints for residential development to protect groundwater resources near Killbuck Creek.

Evaluation of land-use change over time can be useful for planning and management of water resources. For example, land-use changes are an important factor in dam safety because as development downstream from dams brings people and infrastructure nearer to the dam and into a floodplain, redesign of the dams to protect life and property is often needed (Natural Resources Conservation Service, 2001). A specific example of the effect of land-use changes on water resources within the basin was given by Bauder (1994), who documented unusual dewatering of a wetland in Summit County due to the construction of roads, increased industrial water use, and construction of a dike. But changes in land use through time can be difficult to assess because available land-use datasets are often created using different methods with different classification schemes. For this report, the National Land Cover Dataset (NLCD) 1992/2001 Retrofit Change Product (Multi-Resolution Land Characteristics Consortium, 2008) was examined to develop an understanding of land-use change in the Tuscarawas River Basin. This dataset was designed specifically for regional-scale comparison of land-cover change over the time period. It is not simply a crosswalk| comparison of the 1992 NLCD and 2001 NLCD but a re-creation of broad scale (Anderson Level I) land use in 1992 and 2001, using a multiple-stage process. The dataset includes "from-to" change classification values representing the change in land use from 1992 to 2001 at a resolution of $30 \mathrm{~m}$. Land-use categories were based on definitions described on the Multi-Resolution Land Characteristics Consortium Web site (http://www.mrlc.gov/changeproduct.php). Because of the differences in classification methodologies, the land-use percentages presented in this report may not precisely match data in the 1992 NLCD or 2001 NLCD.

Initially, land use in the basin was grouped into seven major classifications as described by the National Land Cover Dataset Retrofit Change Product (Multi-Resolution Land Characteristics Consortium, 2008). Those classifications were open water, forest, grassland/shrub, agriculture, wetlands, urban, and barren. The barren class included strip mines and gravel pits. The urban class included industrial, commercial, and residential development of varying intensities. On the basis of the 1992/2001 Retrofit Change Product, the dominant land uses in the basin in 2001 were forested (40 percent of the basin area) and agriculture (39 percent of the basin area); however, these land uses were not distributed evenly throughout the basin. Agriculture was dominant in the northern part of the basin, whereas forested was dominant in the south (fig. 6 and table 2A). The remaining land uses in the basin in 2001 consisted of urban/residential (17 percent), grassland/shrub (1.8 percent), open water ( 1.5 percent), wetland ( 0.7 percent), and barren ( 0.1 percent. (Data for grassland/shrub, open water, wetland, and barren were removed from table 2 and figure 6 because they accounted for less than 2 percent of the area for all classes.) 
$82^{\circ}$

$81^{\circ}$

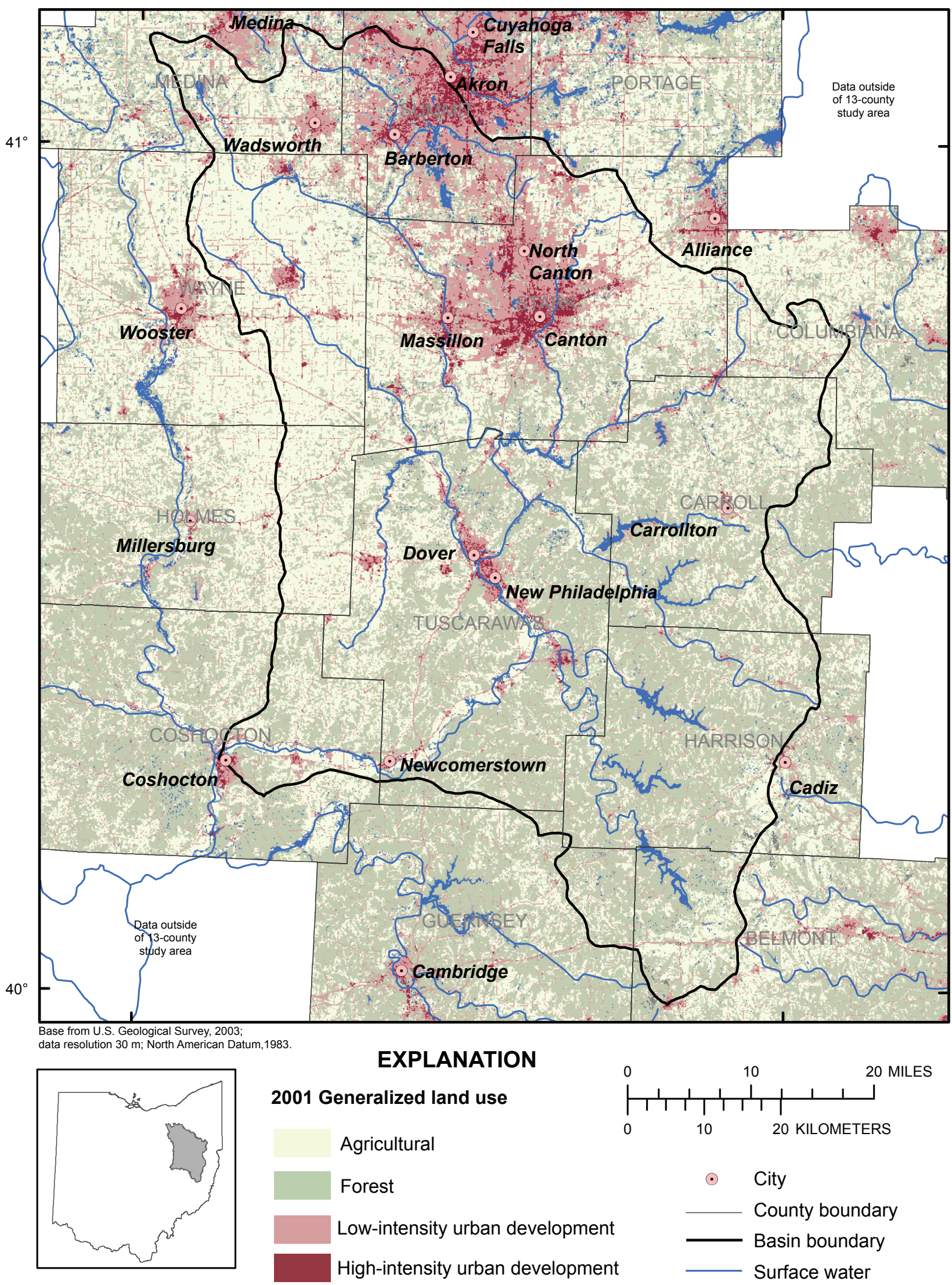

Figure 6. Generalized land use in and around the Tuscarawas River Basin, Ohio, 2001. (Modified from Multi-Resolution Land Characteristics Consortium, 2008) 
Table 2. Land use in and around the Tuscarawas River Basin, Ohio, $(A)$ as percentage of basin area, and (B) as percentage of county area, 1992 and 2001.

[Data from Multi-Resolution Land Characteristics Consortium, 2009; tables do not sum to 100 percent because not all land-use categories are shown; $<$, less than]

\begin{tabular}{|c|c|c|c|c|c|c|c|c|c|}
\hline & \multicolumn{9}{|c|}{ A. Land use in basin, as percentage of basin area } \\
\hline & \multicolumn{3}{|c|}{ Agricultural } & \multicolumn{3}{|c|}{ Forested } & \multicolumn{3}{|c|}{ Urban } \\
\hline & 1992 & 2001 & Change & 1992 & 2001 & Change & 1992 & 2001 & Change \\
\hline Belmont & 1.1 & 1.0 & 0.1 & 2.1 & 2.1 & $<0.1$ & 0.2 & 0.2 & $<0.1$ \\
\hline Carroll & 4.1 & 4.3 & .2 & 6.8 & 6.6 & -.2 & .9 & 9 & $<.1$ \\
\hline Columbiana & 1.1 & 1.2 & .1 & .7 & .6 & -.1 & .2 & .2 & $<.1$ \\
\hline Coshocton & 2.0 & 2.1 & .1 & 1.9 & 1.8 & -.1 & .4 & .4 & $<.1$ \\
\hline Guernsey & 0.4 & 0.4 & $<.1$ & 1.2 & 1.2 & $<.1$ & .1 & .1 & $<.1$ \\
\hline Harrison & 2.5 & 2.5 & $<.1$ & 7.8 & 7.8 & $<.1$ & .8 & .7 & $<.1$ \\
\hline Holmes & 2.6 & 2.6 & $<.1$ & .8 & .7 & -.1 & .2 & .2 & $<.1$ \\
\hline Medina & 2.3 & 2.2 & -.1 & 1.1 & 1.1 & $<.1$ & .8 & .9 & .1 \\
\hline Portage & $<.1$ & $<.1$ & $<.1$ & $<.1$ & $<.1$ & $<.1$ & $<.1$ & $<.1$ & $<.1$ \\
\hline Stark & 7.8 & 8.0 & .2 & 5.2 & 4.6 & -.6 & 5.9 & 6.2 & .3 \\
\hline Summit & 1.0 & 0.8 & -.2 & 1.5 & 1.4 & -.1 & 3.1 & 3.3 & .2 \\
\hline Tuscarawas & 6.4 & 6.7 & .3 & 11.8 & 11.4 & -.5 & 2.3 & 2.4 & .1 \\
\hline Wayne & 6.7 & 6.9 & .2 & 1.2 & .9 & -.3 & 1.1 & 1.2 & .1 \\
\hline \multirow[t]{4}{*}{ TOTAL BASIN } & 38.0 & 38.9 & .9 & 42.3 & 40.3 & -2.0 & 16.1 & 16.8 & .7 \\
\hline & \multicolumn{9}{|c|}{$B$. Land use in basin, as percentage of county area } \\
\hline & \multicolumn{3}{|c|}{ Agricultural } & \multicolumn{3}{|c|}{ Forested } & \multicolumn{3}{|c|}{ Urban } \\
\hline & 1992 & 2001 & Change & 1992 & 2001 & Change & 1992 & 2001 & Change \\
\hline Belmont & 28.9 & 28.0 & -0.9 & 57.8 & 57.2 & -0.6 & 6.5 & 6.4 & -0.1 \\
\hline Carroll & 33.3 & 35.1 & 1.7 & 55.8 & 53.9 & -2.0 & 7.2 & 7.2 & $<.1$ \\
\hline Columbiana & 53.1 & 59.0 & 6.0 & 36.5 & 30.0 & -6.4 & 8.6 & 8.8 & .2 \\
\hline Coshocton & 44.9 & 47.5 & 2.6 & 44.0 & 40.7 & -3.2 & 9.1 & 9.4 & .3 \\
\hline Guernsey & 24.2 & 23.5 & -.8 & 67.0 & 67.3 & .3 & 6.5 & 6.7 & .2 \\
\hline Harrison & 21.7 & 21.8 & .1 & 67.5 & 67.2 & -.3 & 6.6 & 6.4 & -.2 \\
\hline Holmes & 71.3 & 73.1 & 1.9 & 21.4 & 19.3 & -2.2 & 6.3 & 6.4 & .2 \\
\hline Medina & 52.7 & 50.6 & -2.1 & 24.4 & 25.0 & .6 & 19.2 & 20.4 & 1.2 \\
\hline Portage & 43.0 & 43.3 & .4 & 33.3 & 32.2 & -1.0 & 19.7 & 19.9 & .2 \\
\hline Stark & 40.0 & 40.9 & .9 & 26.7 & 23.8 & -2.9 & 30.2 & 31.7 & 1.6 \\
\hline Summit & 15.9 & 13.5 & -2.4 & 24.9 & 23.6 & -1.3 & 51.2 & 54.2 & 3.0 \\
\hline Tuscarawas & 30.1 & 31.5 & 1.4 & 55.3 & 53.1 & -2.2 & 10.8 & 11.1 & .2 \\
\hline Wayne & 73.3 & 75.1 & 1.8 & 13.0 & 10.2 & -2.8 & 12.0 & 12.8 & 0.8 \\
\hline
\end{tabular}


In 1992 and 2001, 5 of the 13 counties that encompass the Tuscarawas River Basin had greater than 50 percent forested land use (Belmont, Carroll, Guernsey, Harrison, and Tuscarawas) and four counties had greater than 50 percent agricultural land use (Columbiana, Holmes, Medina, and Wayne; table 2B). In 2001, Stark County had the greatest percentage of agricultural land use in the basin ( 8 percent of the total agricultural land use in the basin and 41 percent in the county), whereas Tuscarawas County had the greatest percentage of forested land use in the basin (11 percent of the total forested land use in the basin and 53 percent in the county).

The metropolitan areas of Canton and Akron in Stark and Summit Counties are located in and around the northern headwaters of the basin. Approximately 56 percent of all urban land use in the basin was in these two counties (table $2 A$ ). As noted above, the distribution of population (and resulting urban land uses) within the basin is atypical of other large basins in Ohio, such as the Maumee and Great Miami River Basins. The Tuscarawas River Basin is characterized by population centers that include industrial and residential land uses in the headwaters areas of the basin with agricultural and forested land uses towards the mouth, whereas in the Maumee and Great Miami River Basins, most of the agricultural and forested land uses are in the headwaters areas, and industrial and residential land uses are near or at the river mouth near major cities that include Toledo and Cincinnati, respectively.

In general, only a small amount of localized change has occurred in the land use in the basin between 1992 and 2001. During this time, approximately 2 percent of the basin area that was previously devoted to forested land use was converted to agricultural and urban land uses, but the dominant land use within each individual county remained the same (table $2 B$ ). A similar observation was made by the Stark County Regional Planning Commission (1997) which noted that, between 1975 and 1994, land uses in the Stark County area changed very slowly towards greater urbanization.

\section{Geology}

A large amount of work was done in the early to mid1900s to define the geology of the basin because of interest in local coal, oil and gas, and mineral reserves. Reports published through the Ohio Department of Natural Resources by Stout (1916, 1918, 1943), Conrey (1921), Stout and Lamborn (1924), Lamborn (1930, 1954, 1956), Lamborn and others (1938), White (1949), White and Lamborn (1949), DeLong and White (1963), DeLong (1965a, 1965b), and Winslow and White (1966) provide much of the early framework upon which current understanding of Tuscarawas River Basin geology is based.

\section{Bedrock}

The rocks of greatest importance to the water resources of the basin are those that are within $300 \mathrm{ft}$ of land surface; however, a brief description of rocks found at greater depths also is warranted. At depths ranging from approximately 5,500 ft below sea level (NAVD 88) in the western part of the basin to almost 12,000 feet in the southeast part of the basin, the "basement" beneath the Tuscarawas River Basin is composed of Precambrian-age metamorphic and igneous rocks. The lithology and structure of these rocks have been investigated by McCormick (1961), Summerson (1962), Owens (1966), Smith (1969), Risser (1976, 1983a), Vormelker, (1981a, 1981b), and Baranoski (2002). The map produced by Baranoski (2002) shows that the surface of the top of Precambrian-age rocks in the basin slopes at about $60 \mathrm{ft}$ per mile to the southeast. The Precambrian-age rocks are overlain by thick sequences of Cambrian-, Ordovician-, Silurian-, and Devonian-age sedimentary rocks that primarily consist of sandstone, shale, and limestone (Stauffer, 1909; Prosser, 1912; Hoover, 1960; Dow, 1962; Calvert, 1963; Ulteig, 1964; Owens, 1970; Janssens, 1973, 1977; Gray and others, 1982). A cross section by Shearrow (1957) shows that the sedimentary rocks dip to the southeast, typically at a slope slightly less than that of the basement rocks, and that the sedimentary rocks thicken towards the east.

Within $300 \mathrm{ft}$ of the surface, the rocks are Upper Devonian-, Mississippian-, Pennsylvanian-, and Permian-age sandstones, coals, shales, and limestones (fig. 7). A generalized stratigraphic section of the shallow sequence of rocks modified from the U.S. Geological Survey (2009) and Hull (1990) is provided in figure 8 . Bedrock units that serve as regional aquifers in and around the basin are identified on this figure. The oldest rocks within $300 \mathrm{ft}$ of the surface are Upper Devonianor Lower Mississippian-age sandstones that include the Berea and the Cussewago Sandstones described by Winslow and White (1966), DeLong (1968, 1969), Rau (1969), and Struble and Hodges (1982). Mississippian-age rocks in eastern Ohio are mostly sandstones (Morse, 1910; Hyde, 1953; Owens, 1970; and Majchszak, 1984) but include limestones, such as the Maxville Limestone (Morse, 1910; Lamborn, 1945, 1951). The Maxville Limestone is unconformably overlain by the Pennsylvanian-age Sharon Conglomerate, which is a substantial source of groundwater to wells and springs in the northern part of the basin. Fuller (1955) describes the Sharon Conglomerate in detail and provides an explanation of its geologic origin. Pennsylvanian-age rocks in southeastern Ohio are dominated by coal sequences that are described later in this section. The youngest consolidated rocks include Permian (?) and Upper Pennsylvanian-age Dunkard Group mudstones, shales, and sandstones that are present only in small areas in the southeast part of the basin in Belmont County (Stauffer and Schroyer, 1920; Martin, 1998). 

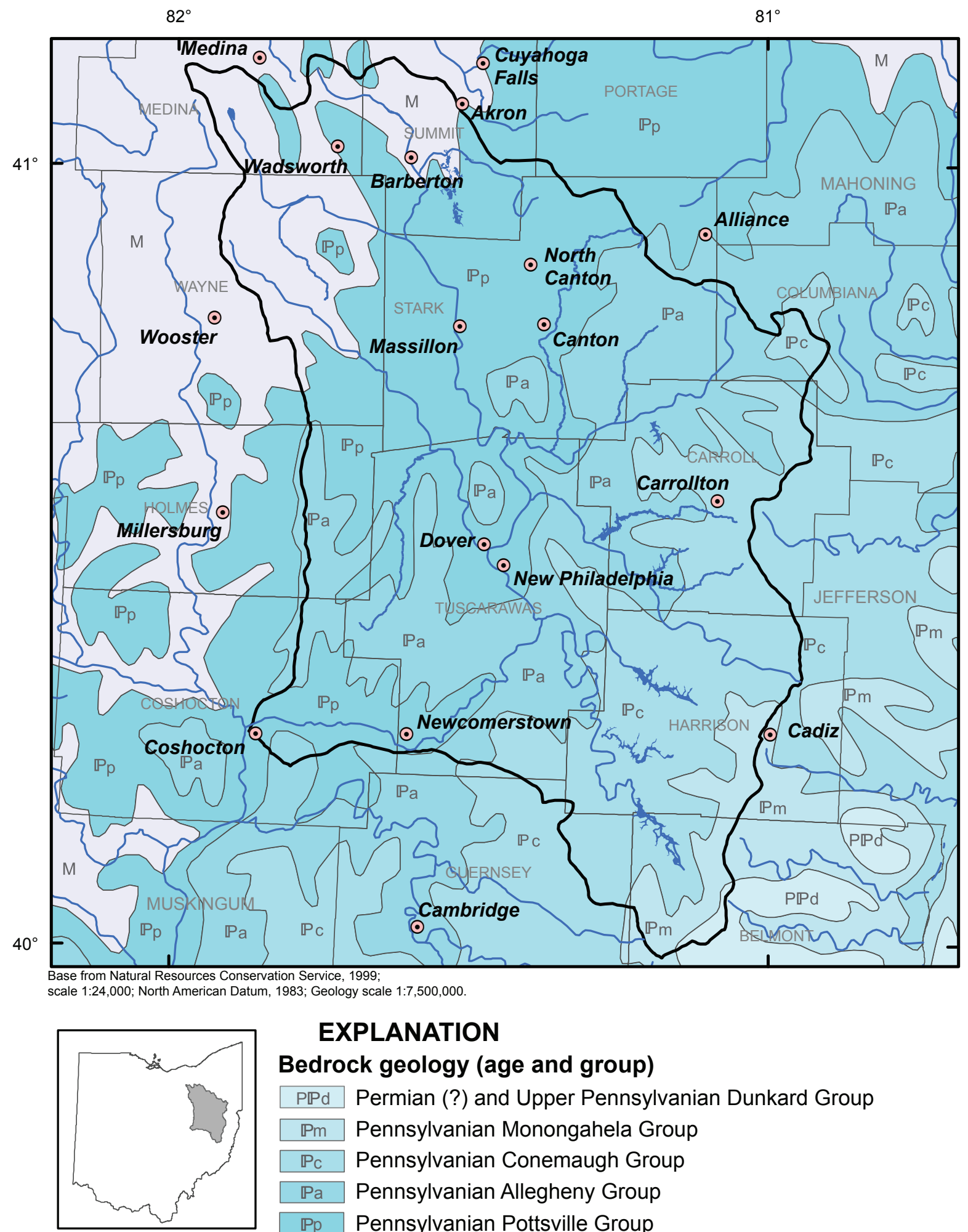

\section{EXPLANATION}

\section{Bedrock geology (age and group)}

PPd Permian (?) and Upper Pennsylvanian Dunkard Group

$\mathbb{P m}$ Pennsylvanian Monongahela Group

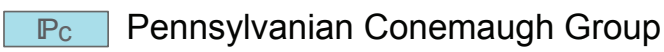

$\mathbb{P a}$ Pennsylvanian Allegheny Group

Pp Pennsylvanian Pottsville Group

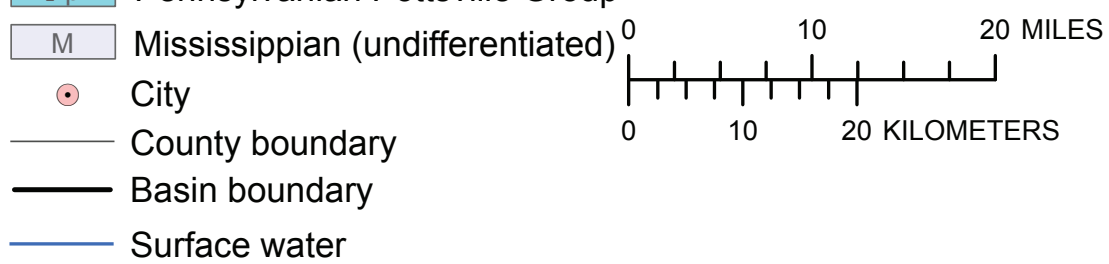

Figure 7. Generalized bedrock geology in and around the Tuscarawas River Basin, Ohio. (From U.S. Geological Survey, 2005) 


\begin{tabular}{|c|c|c|c|c|c|}
\hline \multirow[b]{2}{*}{$\begin{array}{l}\text { System / } \\
\text { period }\end{array}$} & \multirow[b]{2}{*}{$\begin{array}{c}\text { Group } \\
\text { (symbol on } \\
\text { fig.7) }\end{array}$} & \multirow[b]{2}{*}{ Formation } & \multicolumn{2}{|c|}{ Rock Unit } & \multirow[b]{2}{*}{$\begin{array}{l}\text { Local name } \\
\text { Hull (1990) }\end{array}$} \\
\hline & & & $\begin{array}{c}\text { U.S. } \\
\text { Geological } \\
\text { Survey (2009) }\end{array}$ & Hull (1990) & \\
\hline \multirow[b]{2}{*}{$\begin{array}{c}\text { Permian (?) } \\
\text { and Upper } \\
\text { Pennsylvanian }\end{array}$} & \multirow[b]{2}{*}{$\begin{array}{c}\text { Dunkard Group } \\
(\mathrm{PPd})\end{array}$} & $\begin{array}{c}\text { Greene } \\
\text { Formation }\end{array}$ & & & \\
\hline & & $\begin{array}{l}\text { Washington } \\
\text { Formation }\end{array}$ & $\begin{array}{l}\text { Marietta Sandstone } \\
\text { Washington Formation } \\
\text { Mannington Sandstone } \\
\text { Waynesburg Formation }\end{array}$ & $\begin{array}{l}\text { Upper Marietta sandstone } \\
\text { Creston-Reds shale } \\
\text { Lower Marietta sandstone } \\
\text { Washington coal } \\
\text { Mannington sandstone } \\
\text { Waynesburg sandstone }\end{array}$ & No. 12 coal \\
\hline \multirow{5}{*}{ Pennsylvanian } & $\begin{array}{l}\text { Monongahela } \\
\text { Group } \\
\text { (Pm) }\end{array}$ & & $\begin{array}{l}\text { Benwood Limestone } \\
\text { Sewickly Member }\end{array}$ & $\begin{array}{l}\text { Waynesburg coal } \\
\text { Uniontown coal } \\
\text { Benwood limestone } \\
\text { Upper Sewickly sandstone } \\
\text { Meigs Creek coal } \\
\text { Fishpot limestone } \\
\text { Redston-Pomeroy coal } \\
\text { Pittsburgh coal } \\
\end{array}$ & $\begin{array}{l}\text { No. } 11 \text { coal } \\
\text { No. } 10 \text { coal } \\
\text { Goose Run } \\
\text { No. } 9 \text { coal } \\
\\
\text { No. } 8 \mathrm{a} \text { coal } \\
\text { No. } 8 \text { coal } \\
\end{array}$ \\
\hline & \multirow[b]{2}{*}{$\begin{array}{l}\text { Conemaugh } \\
\text { Group } \\
\left(\mathbb{P c}_{\mathrm{c}}\right)\end{array}$} & $\begin{array}{l}\text { Casselman } \\
\text { Formation }\end{array}$ & Conellsville Sandstone & $\begin{array}{l}\text { Summerfield limestone } \\
\text { Conellsville sandstone } \\
\text { Morgantown sandstone } \\
\text { Skelley limestone }\end{array}$ & $\begin{array}{l}\text { Mitchell } \\
\text { Wolf Creek }\end{array}$ \\
\hline & & $\begin{array}{l}\text { Glenshaw } \\
\text { Formation }\end{array}$ & $\begin{array}{l}\text { Ames limestone } \\
\text { Saltsburg Sandstone } \\
\text { Cow Run Sandstone } \\
\text { Cambridge limestone } \\
\text { Buffalo sandstone } \\
\text { Brush Creek limestone } \\
\text { Mahoning Sandstone } \\
\end{array}$ & $\begin{array}{l}\text { Ames limestone } \\
\text { Harlem coal } \\
\text { Noble limestone } \\
\text { Saltsburg sandstone } \\
\text { Cow Run sandstone } \\
\text { Portersville shale } \\
\text { Cambridge limestone } \\
\text { Buffalo sandstone } \\
\text { Brush Creek limestone } \\
\text { Rock Camp shale } \\
\text { Mahoning coal } \\
\text { Mahoning sandstone } \\
\end{array}$ & $\begin{array}{l}\text { Peeker } \\
\text { First Cow Run } \\
\text { Buell Run } \\
\text { No. 7a coal } \\
\text { Macksburg 300' }\end{array}$ \\
\hline & $\begin{array}{l}\text { Allegheny } \\
\text { Group } \\
(\mathbb{P a})\end{array}$ & & $\begin{array}{l}\text { Dorr Run shale } \\
\text { Obryan Member } \\
\text { Columbiana Member } \\
\text { Vanport limestone } \\
\text { Clarion sandstone / shale } \\
\text { Putnam Hill Limestone } \\
\text { Brookville Clay Member }\end{array}$ & $\begin{array}{l}\text { Upper Freeport coal } \\
\text { Upper Freeport sandstone } \\
\text { Dorr Run shale } \\
\text { Lower Freeport coal } \\
\text { Washingtonville shale } \\
\text { Middle Kittanning coal } \\
\text { Obryan limestone - } \\
\quad \text { Columbiana shale } \\
\text { Lower Kittanning coal } \\
\text { Vanport limestone } \\
\text { Clarion coal } \\
\text { Putnam Hill limestone } \\
\text { Newland-Brookville coal } \\
\end{array}$ & $\begin{array}{l}\text { No. } 7 \text { coal } \\
\text { Second Cow Run } \\
\text { No. } 6 \text { a coal } \\
\text { No. } 6 \text { coal } \\
\text { No. } 5 \text { coal } \\
\text { No. } 4 \text { a coal } \\
\text { No. } 4 \text { coal }\end{array}$ \\
\hline & $\begin{array}{l}\text { Pottsville } \\
\text { Group } \\
\text { (Pp) }\end{array}$ & & $\begin{array}{l}\text { Homewood Sandstone } \\
\text { Member } \\
\text { Boggs limestone } \\
\text { Massillon Sandstone } \\
\text { Member } \\
\text { Lowellville limestone } \\
\text { Sharon Cong Member }\end{array}$ & $\begin{array}{l}\text { Homewood sandstone } \\
\text { Upper Mercer limestone } \\
\text { Lower Mercer limestone } \\
\text { Lower Mercer coal } \\
\text { Boggs limestone } \\
\text { Massillon sandstone } \\
\text { Quakertown coal } \\
\text { Poverty Run-Lowellville } \\
\text { limestone } \\
\text { Sharon coal } \\
\text { Sharon sandstone/cong }\end{array}$ & $\begin{array}{l}\text { Macksburg 700' } \\
\text { No. } 3 \text { coal } \\
\text { Salt, Upper salt } \\
\text { No. } 2 \text { coal } \\
\text { Brill Sand } \\
\text { No. } 1 \text { coal } \\
\text { Maxton, Lower Salt }\end{array}$ \\
\hline \multirow{7}{*}{ Mississippian } & \multirow{7}{*}{$(\mathrm{M})$} & & Maxville Limestone & Maxville Limestone & \multirow{5}{*}{ Keener } \\
\hline & & & Rushville Formation & Rushville Shale & \\
\hline & & \multirow{3}{*}{$\begin{array}{l}\text { Logan } \\
\text { Formation }\end{array}$} & $\begin{array}{l}\text { Vinton Member } \\
\text { Allensville Conglomerate } \\
\text { Member }\end{array}$ & $\begin{array}{l}\text { Vinton Member } \\
\text { Allensville Member }\end{array}$ & \\
\hline & & & Byer Member & Byer Member & \\
\hline & & & $\begin{array}{l}\text { Berne Conglomerate } \\
\text { Member }\end{array}$ & Berne Member & \\
\hline & & $\begin{array}{l}\text { Cuyahoga } \\
\text { Formation }\end{array}$ & $\begin{array}{l}\text { Black Hand Sandstone / } \\
\text { Formation }\end{array}$ & Black Hand Member & $\begin{array}{l}\text { Big Injun, Squaw, } \\
\text { Weir, Hamden }\end{array}$ \\
\hline & & & Sunbury Shale & Sunbury Shale & Coffee Shale \\
\hline \multirow{3}{*}{ Devonian } & \multirow{3}{*}{ (not shown) } & & Berea Sandstone & Berea Sandstone & \multirow{3}{*}{$\begin{array}{l}\text { First Berea } \\
\text { Second Berea }\end{array}$} \\
\hline & & & $\begin{array}{l}\text { Bedford Shale / } \\
\text { Formation } \\
\end{array}$ & Bedford Shale & \\
\hline & & & Cussewago Sandstone & Cussewago Sandstone & \\
\hline \multicolumn{6}{|c|}{ Underlying (older) rocks excluded } \\
\hline
\end{tabular}

Figure 8. Generalized stratigraphic section of rocks within 300 feet of the surface in the Tuscarawas River Basin, Ohio. (Modified from U.S. Geological Survey (2009) and Hull (1990); shaded rock units are regional aquifers (other units may be local aquifers)) 


\section{Unconsolidated Sediments}

Unconsolidated sediments in the northern part of the Tuscarawas River Basin are dominated by glacially derived till, sand, and gravel; however, reworked glacial deposits and alluvial deposits also fill the valleys elsewhere in the basin (for the purposes of this description, unconsolidated sediments include both glacial and alluvial sediments). The glacial history of the Tuscarawas River Basin is fairly complex and has been studied by many investigators, including White $(1951,1967,1973$, 1979, 1982, 1984), Forsyth (1961), Goldthwait and others (1967), Ohio Department of Natural Resources (1978a, 1983, 1993a, 1993b), White and Guckenheimer (1979), White and Totten (1979, 1982, 1985), Totten (1988), and Pavey and others (1999). At least two distinct periods of glaciation occurred in Ohio within the past 150,000 years: the Illinoian age (which ended approximately 125,000 years ago) and the Wisconsinan age (which ended approximately 10,000 years ago). In general glaciers advanced southward from Canada, across the Great Lakes and into Ohio and covered the upper third of the basin. Much of the area covered by the Illinoian glaciers was overrun and reworked by Wisconsinan-age glaciers. The only remaining Illinoian glacial sediments exposed at the surface in the Tuscarawas River Basin are along a relatively thin east-west band in Columbiana County shown in red on the map of generalized soil regions (fig. 4).

Much of the unconsolidated sediment derived from glaciers is fine-grained silt and clay that forms a blanket over the bedrock, generally less than $100 \mathrm{ft}$ thick. However, the unconsolidated sediments also contain sand and gravel outwash that fills incised river valleys. These outwash deposits extend well beyond the extent of glaciation because meltwater carried the sediments away from the glacier towards the Ohio River (fig. 9; note that surface water and unconsolidated surficial sediments may not necessarily coincide in river valleys in figure 9 because of the different source scales of these two map layers). Additionally, alluvial sediments, which are undifferentiated from the glacial sediments in figure 9, fill valleys in unglaciated areas.. Other sand and gravel deposits of glacial origin, including terraces, kames, and eskers, are in Coshocton County and in the Akron, Canton, and Massillon areas (Smith, 1949; Van Horn, 1979; Hull, 1980; and Himes, 1982).

\section{Mineral Resources}

Considerable mineral resources are within the rocks and sediments of the Tuscarawas River Basin, and these resources have helped to define the economy and industry of the area (Bownocker and Stout, 1928; Stout, 1946; Ohio Department of Natural Resources, 1963; and Carlson, 1991). In 2006, total revenue from Ohio's mineral-based commodities since records have been kept was estimated at more than $\$ 2.6$ billion (Ohio Department of Natural Resources, 2007a). Oil and gas production produced the most revenue in Ohio, totaling slightly more than $\$ 1$ billion, whereas coal production resulted in a net value of approximately $\$ 618$ million. Mineral commodities production numbers are available through the Ohio Department of Natural Resources Web site at http://www.dnr.state. oh.us/.

Mining operations (fig. 10) include those that extract and (or) process coal, metals (chromium, sulfur, and tin), minerals, unconsolidated materials, and rocks. Dimension stone and sand and gravel are used for construction. Clay, shale, limestone, dolomite, sand, gravel, sandstone, conglomerate, and other deposits are used as aggregate. Oil and gas wells were too numerous to show in figure 10.

\section{Oil and Gas}

Oil and gas production has been and continues to be a major economic boon to residents and industries in the Tuscarawas River Basin. In Ohio, oil wells were first drilled northeast of the Tuscarawas River Basin in Trumbull County in 1859 (Ohio Department of Natural Resources, 2007b). Publications and maps describing the occurrence of oil and gas were produced by Bownocker (1903), Multer (1963), Janssens and de Witt (1976), Struble and Hodges (1982), and Ohio Department of Natural Resources (2007b). In general, oil and gas reservoirs are much deeper than potable-water aquifers in the basin; therefore, drilling and extraction of oil through wells requires penetration through the shallow aquifers. Drilling through the aquifers and extracting oil and gas requires special precautions to avoid contamination of overlying aquifers and nearby surface-water bodies from oil-field brines (brines are extremely saline waters from deep geologic formations that contain high concentrations of dissolved constituents as described by Lamborn (1952) and Breen and others (1985)).

\section{Coal}

Coal is present in Pennsylvanian-age rocks in all counties within the basin (figs. 8 and 10). The sheer number and volume of coal-related documents verify coal's importance to the economy of eastern Ohio (see, for example, Bownocker and others, 1908; Condit, 1912; Stout, 1929, Lamborn, 1942; White, 1947; Brant, 1954, 1956; DeLong, 1955, 1957; DeBrosse 1957; Granchi, 1958; Brant and DeLong, 1960; Denton, 1960; Couchot, 1978; Couchot and others, 1980; and Axon, 1996). In Ohio, coal deposits are characterized by repetitive sequences of sandstone, shale, limestone, coal, and clay. In the Tuscarawas River Basin, coal occurs in seams that range from a couple of inches to several feet thick.

Coal has been mined and used for domestic purposes by Native Americans and early settlers since before records were kept. The first written record of coal in Ohio is in a 1748 report of a coal mine fire at the mouth of Sandy Creek near Bolivar, Tuscarawas County (Ohio Department of Natural Resources, 1997a). Documentation of the amount of coal produced in Ohio began around 1800, and between that time and the present, more than 5 billion tons of coal has been mined. At least two peaks in production have occurred, the first during World War I and the second during the early 1970's, when large surface-mining operations were in production. For the 

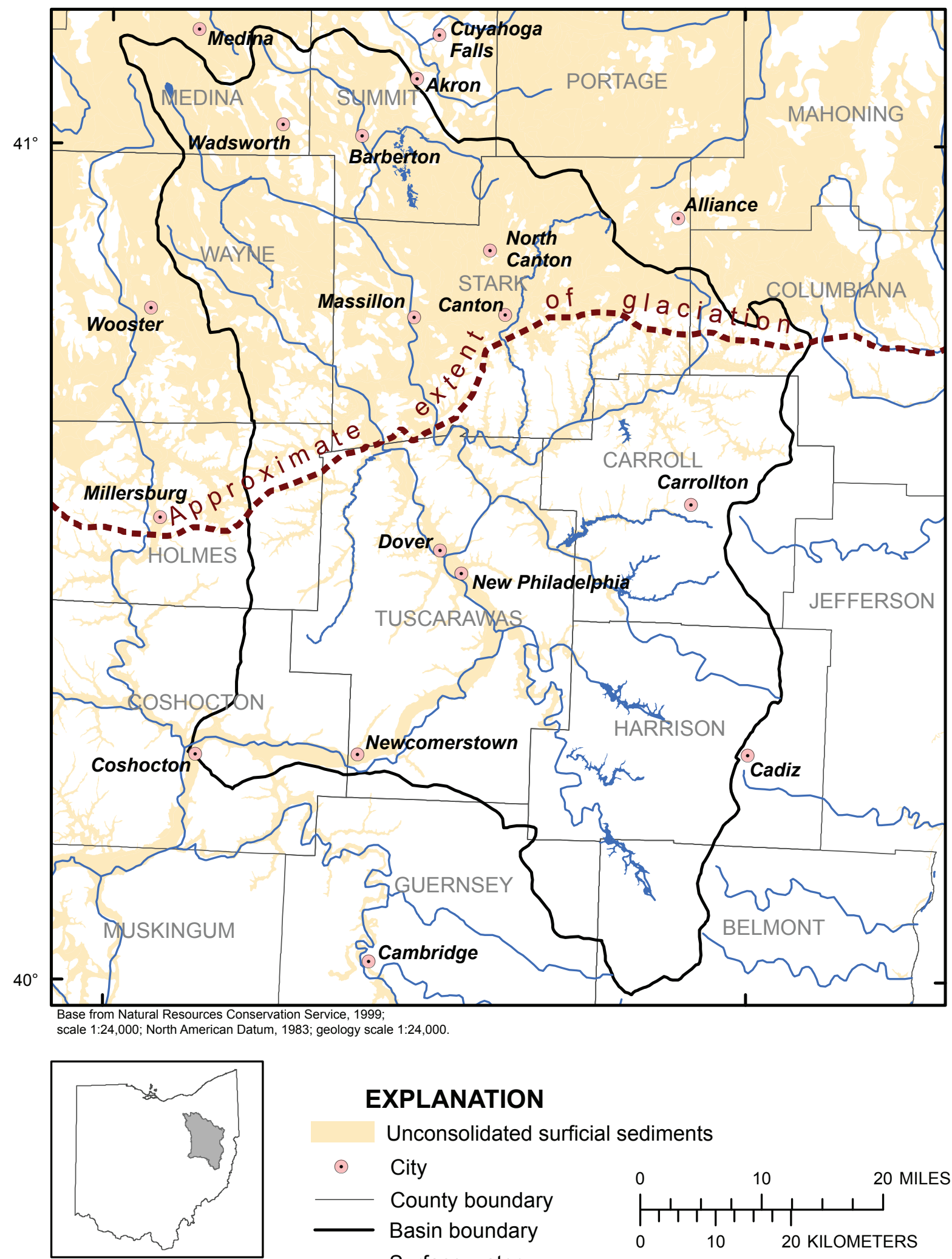

\section{EXPLANATION}

Unconsolidated surficial sediments

- City

County boundary

Basin boundary

Surface water

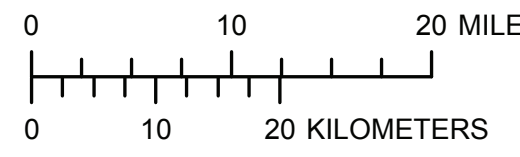

Figure 9. Unconsolidated surficial sediments in and around the Tuscarawas River Basin, Ohio. (Modified from Ohio Department of Natural Resources, 2000a) 


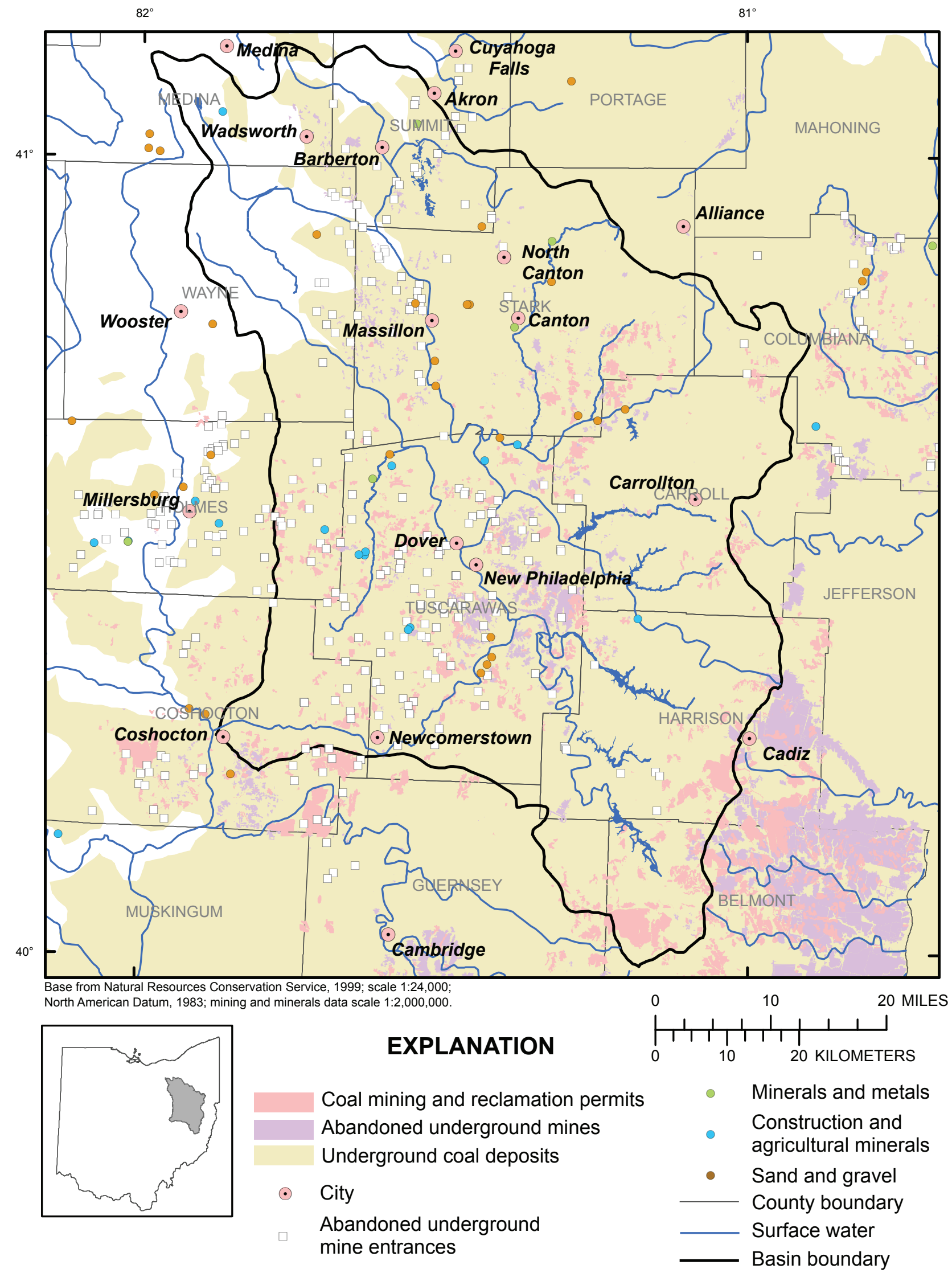

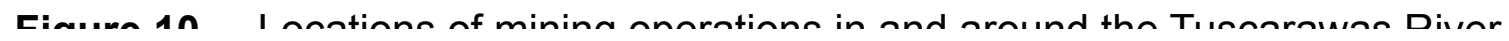

Figure 10. Locations of mining operations in and around the Tuscarawas River Basin, Ohio. (From Ohio Department of Natural Resources (1999a, 1999b) and U.S. Geological Survey (2005)) 
interested reader, the history of the coal-mining industry in Ohio is further described in Crowell (1995) and Ohio Department of Natural Resources (1997a).

Within the Tuscarawas River Basin, several counties are among the leaders in Ohio coal production (Ohio Department of Natural Resources, 2007a). As of 1997, Belmont County produced over 774 million tons of coal and was (and continues to be) the leading coal-producing county in Ohio. Harrison, Tuscarawas, and Guernsey Counties also are among the top 10 coal-producing counties in Ohio. Production of coal within the basin and throughout eastern Ohio is closely correlated with oil and gas prices and the increasing costs associated with air-quality requirements of the Clean Air Act of 1970 and its amendments in 1977. Ohio coal typically contains from 2 to 7 percent sulfur, requiring special measures to reduce or eliminate sulfur-rich emissions that may be discharged to the atmosphere. Also, Ohio coal may contain other minerals and trace elements that can cause environmental concerns related to disposal of ash, air emissions, and degraded water quality (Bownocker and Dean, 1929; Dean, 1948; Knapp, 1977; Botoman and Stieglitz, 1978; Botoman and Stith, 1978, 1981, 1986, 1988; Bragg and others, 1998; Haefner, 2002).

\section{Other Mineral Resources}

In addition to oil, gas, and coal, there are many other mineral deposits of economic significance in the Tuscarawas River Basin. Carlson (1991) and the 2006 Ohio Minerals Report (Ohio Department of Natural Resources, 2007a) list economically viable mineral reserves of sand and gravel, salt, clay, limestone, sandstone, silica, gypsum, and peat in Ohio. Iron ore and flint also have been produced in Ohio (Stout, 1944; Stout and Schoenlaub, 1945). Unconsolidated surficial sediments shown in figure 9, which include sand and gravel deposits, can be found throughout the basin (Smith, 1949; Hull, 1980, 1987; Risser, 1981, 1986, 1987). Sand and gravel has many uses, most importantly as aggregate in concrete used for construction and repair of buildings and roads. Salt deposits in Silurian-age rocks are present deep below the surface of the basin. The salt is typically extracted by injecting water into injection wells, which causes the salt to dissolve, and the resulting salt solution is pumped to the surface (Pepper, 1947; Clifford, 1973; Ohio Department of Natural Resources, 2007a). There is a long history of clay mining and production of ceramics and pottery within the basin. Parts of east-central Ohio are internationally known for their pottery (Lamborn and others, 1938; Stout, 1940a; Stout and others, 1923; Kent State University Museum, 2008; and Ohio History Central, 2008). Limestone resources were described by Orton and Peppel (1906) and Lamborn (1945, 1951); however, as is the case for peat, marl, tufa rock, travertine, and bog ore in Ohio, they are not found in large quantities and are not a substantial source of revenue within the basin (Dachnowski, 1912; Stout 1940b; Ohio Department of Natural Resources, 2007a).
The mineral deposits described above are not only important economically to the residents and industry of the Tuscarawas River Basin, but also hydrologically because the mining and extraction activities have the potential to affect water quality and (or) alter local and regional groundwater and surface-water flow paths. As described in the upcoming sections of this report, disturbances of the natural hydrologic system are evident in many areas of the basin, and the legacy of early mining practices continues to be one of the dominant water-quality issues in the basin.

\section{Hydrology}

The major water feature within the basin is the Tuscarawas River. Basic information regarding the basin can be found on the U.S. Environmental Protection Agency's "Surf your Watershed" Web site at http://cfpub.epa.gov/surf/huc. cfm?huc_code $=05040001$. The earliest reports describing the water resources of the Tuscarawas River Basin focused on water quantity and sources of potable water rather than water quality (Foulk, 1925; Ohio Department of Public Works and Dayton Morgan Engineering Co., 1931; Harker, 1943a, 1943b, 1943c; Stout and others, 1943; Van Tuyl 1947; Kazman, 1949; Smith and White, 1953; Stafford, 1954; Walker, 1959; Kaser, 1960; Ohio Water Commission, 1960). Major water inventories were conducted for the entire Muskingum River Basin (Ohio Department of Natural Resources, 1968) and for the Tuscarawas River, Nimisilla Creek, Portage Lakes, and Nimisilla Reservoir (Stafford, 1954). These publications document the similarity between the hydrology of the Tuscarawas River Basin and other basins in the Midwestern United States in terms of sources, quantity, quality, and sinks of water. The primary source of water to the basin is precipitation; however, unknown amounts of water may be entering through groundwater flow within aquifers whose boundaries do not necessarily coincide with surface-water divides. Surface-water divides are defined by topography, whereas groundwater divides are defined by the water table and may be affected by withdrawals, geologic structure, or other factors. Groundwater inflow into the Tuscarawas River Basin from outside the basin has not been evaluated; however, Stout and others (1943) note that groundwater flow directions in deep consolidated rock formations are generally from west to east. Discharge/Loss of water is through evapotranspiration, groundwater (well) withdrawals that are generally unaccounted for, and streamflow at the mouth of the Tuscarawas River near Coshocton.

To understand the most important components of the hydrology of the basin, the Ohio Department of Natural Resources published the general water budget shown below (Ohio Department of Natural Resources, 2008c). Two assumptions with this budget are that, in the long term, there are no net gains or losses in the overall amount of water in the basin and that all precipitation that falls in the basin leaves the basin through runoff to streams, evaporation, transpiration by plants, or well withdrawals. 


\section{Annual Water Budget for Ohio}

[Modified from Ohio Department of Natural Resources, 2008c]

Begin with an average of 38 inches annual precipitation as rainfall or snowfall.

Of the 38 inches of precipitation,

10 inches runoff to streams

2 inches are lost to evaporation

26 inches infiltrate into the ground

Of the 26 inches that infiltrate into the ground,

20 inches are lost to evapotranspiration

6 inches recharge groundwater

Of the 6 inches that recharge groundwater,

2 inches discharge to surface water

4 inches are lost to evapotranspiration or to well withdrawals

The following section describes the major components of this water budget - evapotranspiration, surface water, and groundwater- and concludes with the overall water-use characteristics in the Tuscarawas River Basin.

\section{Evapotranspiration}

Relatively large amounts of water leave the basin through evapotranspiration, or water lost through evaporation and transpiration by plants (Ohio Department of Natural Resources, 2008c). Thornthwaite (1948) and Allen and others (1998) summarize different methods of estimating or measuring evapotranspiration. Typically, estimation of evapotranspiration involves the use of equations through a water- or energybalance approach (water or energy inputs equal outputs plus or minus a change in storage) or through other equations that include atmospheric, hydrologic, and (or) vegetation data. Evapotranspiration also can be estimated through calibration of groundwater flow models, where recharge rates (which include losses due to evapotranspiration) are adjusted until the models produce realistic groundwater levels and streamflows.

Harstine (1991) provided measurements of potential evaporation rates for nine sites in Ohio for the months of May through October. No measurements were obtained within the Tuscarawas River Basin; however, measurements were made for nearby sites Coshocton Agricultural Research Station (34.2 in/yr: Coshocton County), Seneca Lake (31.2 in/yr; Guernsey County), and Wooster Experimental Station (31.2 in/yr; Wayne County). The average potential evaporation rate for all nine sites was $30.8 \mathrm{in} / \mathrm{yr}$. Through measurements obtained at the Ohio Agricultural Research and Development Center in Wooster (Wayne County), Breen and others (1995) used an evapotranspiration rate of $24 \mathrm{in} / \mathrm{yr}$, obtained from measurements provided by the Ohio Agricultural Research and Development Center in Wooster (Wayne County), in their groundwater flow model. Cohen and Randall (1998) estimated evapotranspiration for the entire glaciated region of the northeastern United States, including the Tuscarawas River Basin area that was estimated at about $22 \mathrm{in} / \mathrm{yr}$.

\section{Surface Water}

Four major tributaries of the Tuscarawas River are Sandy Creek (with inflows from Nimishillen Creek), Conotton Creek, Stillwater Creek, and Sugar Creek (fig. 1). The Ohio and Erie Canal was constructed next to the river in the early 1800 s and served as a major transportation route for about 20 years, but its use declined in the 1850s as railroads gained popularity. The canal suffered substantial damage from flooding in 1913, and only small portions of the canal's towpath route are still maintained for recreational uses such as hiking and bicycle trails. The history, operation, and hydraulics of the Ohio and Erie Canal are further described in Ohio Department of Natural Resources (1997b); however, the canal's effects on the hydrology of the basin have not been investigated. The largest surface-water bodies in the basin are a series of man-made reservoirs constructed for flood control, including Atwood Lake, Beach City Lake, Leesville Lake, Tappan Lake, Clendening Lake, and Piedmont Lake (fig. 1). These reservoirs and the associated dams are maintained by the Muskingum Watershed Conservancy District (MWCD) and the U.S. Army Corps of Engineers and are further described in Dames \& Moore and U.S. Army Corps of Engineers Huntington District (1975), U.S. Army Corps of Engineers (1977, 2006a), and Muskingum Watershed Conservancy District (2002). In addition to flood control, the reservoirs are important for recreation, thermoelectric power, and, to a lesser degree, water supply. As of 2009, only Tappan Lake was used for public water supply for the Village of Cadiz (Muskingum Watershed Conservancy District, 2008). The largest natural lakes (which undoubtedly also have been somewhat affected by human activities) include the Portage Lakes in Summit County, which are much smaller than the man-made reservoirs. Studies and inventories of the reservoirs and lakes of Ohio and within the Tuscarawas River Basin have been done by Wright (1950), Tobin and Youger (1978, 1979), Bowell (1980), Black (1991), Davic and others (1997), and the Muskingum River Basin initiative (2005).

\section{Wetlands}

Wetlands throughout Ohio have been mapped and cataloged by the U.S. Fish and Wildlife Service (U.S. Fish and Wildlife Service, 2009a). Wetlands are far more numerous in the northern, glaciated parts of the basin (including Stark, Summit, and Portage Counties) than in the southern, unglaciated parts of the basin. Many of the wetlands, such as Jackson Bog in Stark County and Singer Lake Bog in Summit County, include kettle holes that formed where large chunks of ice left behind by receding glaciers were partially or wholly buried within glacial sediments (Denny, 1988; 
Cleveland Museum of Natural History, 2008; fig. 1). Other important wetlands within and adjacent to the basin include Stillfork Swamp, Killbuck Marsh Wildlife Area, and Reifsnyder Wetlands. Carroll County's Stillfork Swamp is one of the most extensive inland marshes in the unglaciated Western Allegheny Plateau Ecoregion of eastern Ohio. It covers over 600 acres within the Stillfork Valley and drains into Sandy Creek. This swamp has long been recognized for its importance as nesting grounds for a variety of waterfowl and marsh birds (The Nature Conservancy, 2006). The Killbuck Marsh Wildlife Area in Wayne and Holmes County (outside and to the west of the Tuscarawas River Basin) is owned by the Ohio Department of Natural Resources and is the largest freshwater wildlife marsh site in Ohio at 5,492 acres (U.S. Department of Transportation, 2008).

The wetlands described above were created by natural processes; however, Reifsnyder Wetland is a constructed wetland designed to reduce nitrate concentrations flowing into Nimishillin Creek (Earth Action Partnership, Inc., 2006). In addition to Reifsnyder Wetland, other artificial wetlands have been built to intercept and ameliorate acid-mine drainage from coal mines (Bralek and others, 2002; U.S. Environmental Protection Agency, 2006c). Thus, wetlands hold substantial value not only for providing habitat for birds and other wildlife, but also for the abatement of degraded water quality.

\section{Floods}

Flooding has been and continues to be a problem in the Tuscarawas River Basin. Records of floods in the basin within the last century begin with the flood of 1913 (Horton and Jackson, 1913). Floods are documented for the years 1935 (Youngquist and others, 1941), 1959 (Cross and Brooks, 1959; Edelen, Ruggles, and Cross, 1962; Edelen, Somers, and Cross, 1962, Somers and others, 1962), 1998 (Koltun, 1999), and 2005 (The Times Reporter, 2005). The flooding that occurred in 1913 spurred the development of the Muskingum Watershed Conservancy District in 1933 and the construction of a dam and reservoir network later that decade. Within the past 20 years, flood-insurance studies have been done (or updated) for small regions throughout the basin by the U.S. Federal Emergency Management Agency. Past and current flood studies in the basin are available at $h t t p: / / m s c$.fema.gov/.

\section{Groundwater/Surface-Water Interactions}

The relation between groundwater and surface water is complex and the streams within the basin may receive water from aquifers (gaining streams) and contribute water to aquifers (losing streams) over relatively short distances. Well fields installed for public supply are often placed near streams to take advantage of the thick sand and gravel deposits in the area and to induce infiltration of surface water into the aquifer. Van Tuyl (1947) measured streamflow in Nimishillin Creek near Canton and showed that losses of surface water to groundwater occur in varying amounts depending on the stage of the stream and on local groundwater levels. Infiltration rates varied from 0 to more than $3 \mathrm{Mgal} / \mathrm{d}$ per acre of stream bottom. Van Tuyl also documented that as much as 33 percent of the total streamflow infiltrated the aquifer. Rizzo (1993) determined that streams in Medina and Wayne Counties lose a substantial amount of water as the streams flow across permeable sands and gravels within the valleys. Water is initially discharged at the contact between the Sharon Sandstone/Conglomerate and the underlying Wooster Shale. (The Wooster Shale is not present in the Tuscarawas River Basin; however, it is typically found at the same interval as the Black Hand member within the Cuyahoga Formation.) Breen and others (1995) confirmed through a series of seepage-meter experiments that complex surface-water/groundwater interactions occur along Killbuck Creek and its tributaries near Wooster by identifying specific reaches where streamflow increased or decreased due to stream/aquifer interactions.

In addition to groundwater interaction with streams, groundwater interaction with ponds and lakes probably occurs; however, the authors are unaware of any documented interactions between groundwater and lakes or ponds in the basin. A study by Barton and others (1998) on Mosquito Creek Lake in Trumbull County (to the northeast of the Tuscarawas River Basin) revealed that there is a west-to-east component of groundwater flow into and out of the lake with higher groundwater levels on the western shore than on the eastern shore, making Mosquito Creek Lake a flow-through lake.

\section{Groundwater}

The primary sources of groundwater used by the residents and industry in the Tuscarawas River Basin are sandstones of Devonian, Mississippian, and Pennsylvanian age and unconsolidated sands and gravels. As noted in the section describing the geology of the basin, the focus of this report is on consolidated rocks within about $300 \mathrm{ft}$ of the surface and the overlying unconsolidated sands and gravels that fill buried valleys. Water in the upper part of the Devonian-age rocks and lower part of the Mississippian-age rocks becomes brackish and may still be included as part of the potable water resources of the basin (Sedam and Stein, 1970); however, for the purposes of this report, the Upper Devonian- and Lower Mississippian-age rocks will be considered the lower extent of the aquifer system within the basin.

The groundwater resources of the entire Muskingum River Basin were first described by the Ohio Department of Public Works and Dayton Morgan Engineering (1931). Stout and others (1943) followed with the "Geology of Water in Ohio" and stated that "...the thick fill of the valley should provide abundant water and that "Rock Water" found in consolidated Pennsylvanian shales and some sandstones provide fair local supplies." Harker (1943a, 1944a) also documents the abundance of groundwater in the basin, particularly in the buried valleys along the Tuscarawas River.

Several state-wide maps describing groundwater resources within Ohio have been published by the Ohio 
Department of Natural Resources Statewide Aquifer Mapping Project and include "Hydrogeologic Settings of the Unconsolidated Aquifers in Ohio" (Angle and others, 2000), "Drift Thickness of Ohio" (Ohio Department of Natural Resources, 2000a), "Primary Lithology of the Unconsolidated Deposits of Ohio" (Ohio Department of Natural Resources, 2000b), "Yields of the Unconsolidated Aquifers in Ohio" (Ohio Department of Natural Resources, 2000c), and "Yields of the Uppermost Bedrock Aquifers of Ohio" (Ohio Department of Natural Resources, 2000d). County-scale investigations compiled as part of this literature review are listed in appendix 1 and include general water-resources studies (some of which also include surface-water resources), groundwater resources investigations, pollution-potential maps, and water-level maps.

\section{Bedrock Aquifers}

As shown by the shaded rock unit names in the stratigraphic column in figure 8 , the sandstone aquifers that provide much of the water to wells are found in the lower part of the column and include the Cussewago Sandstone, the Berea Sandstone, the Black Hand Sandstone, the Logan Formation, the Maxville Limestone, the Sharon Conglomerate Member, the Massillon sandstone, the Homewood Sandstone, the Upper Freeport sandstone, and the Buffalo Sandstone. Locally, sandstones, coals, and limestones in the upper Pennsylvanian-age and Permian-age rocks also provide water to wells; however, quantities of water withdrawn from these rocks through wells are much smaller than the quantities from above-listed units.

Most of the results of evaluations of groundwater and aquifers are presented in terms of well yields (for example, how much water can be withdrawn before a well goes dry). Well yields in the sandstone aquifers are generally less than $100 \mathrm{gal} / \mathrm{min}$ (gallons per minute) (Sedam, 1973; Ohio Department of Natural Resources, 2000c, 2000d). The relatively poor yield of wells in sandstone aquifers has led to investigation of water in abandoned underground coal mines as an additional source of water (Crouch and others, 1980); however, this water is often of poor chemical quality with elevated concentrations of iron, manganese, and sulfate (Razem and Sedam, 1985). Estimation of aquifer properties including hydraulic conductivity and transmissivity has been done through aquifer tests and calibration of digital computer models, but few references are available for aquifer properties in the consolidated bedrock in the Tuscarawas River Basin. Breen and others (1995) estimated hydraulic conductivity values for the Logan and Cuyahoga Formations near Wooster of 0.25 to $100 \mathrm{gal} / \mathrm{d} / \mathrm{ft}^{2}(0.033$ to $13 \mathrm{ft} / \mathrm{d})$, using aquifer test results and model calibration. Rau (1969) estimated that the average transmissivity of the Berea Sandstone was 2,400 gal/d/ft $\left(320 \mathrm{ft}^{2} / \mathrm{d}\right)$. Lacking other basin-specific data, textbook hydraulic conductivity values may be used; the values for sandstone range from 1 to $1,000 \mathrm{gal} / \mathrm{d} / \mathrm{ft}^{2}(0.13$ to $130 \mathrm{ft} / \mathrm{d})$ and for unfractured limestone, $1 \times 10^{-1}$ to $1 \times 10^{-5} \mathrm{gal} / \mathrm{d} / \mathrm{ft}^{2}\left(1.3 \times 10^{-2}\right.$ to $1.3 \times 10^{-6} \mathrm{ft} / \mathrm{d}$ ) (Domenico and Schwartz, 1990; Freeze and Cherry, 1979). Textbook porosity values for sandstone range from 5 to 30 percent, and specific yield values range from 21 to 27 percent. Similar values for limestones range from 0 to 20 percent porosity and about 14 percent specific yield.

\section{Unconsolidated Aquifers}

The sands and gravels that fill buried valleys in northeastern Ohio are among the most prolific aquifers in the State (Harker and Bernhagen, 1943a; Cummins, 1959; Ohio Department of Natural Resources, 2000c). Indeed, production wells in all of the major cities within the basin obtain water from wells screened within sand and gravel aquifers. The thicknesses of the sand and gravel deposits in the Tuscarawas River Basin typically are greater than $100 \mathrm{ft}$ within the buried valleys and may reach up to $400 \mathrm{ft}$ in some localities near the center of the larger valleys in the northern, glaciated regions. These buried valleys also may contain layers of fine sand, silt, and (or) clay, which may hinder the utilization of groundwater resources, as was the case reported by Harker (1944a) in the vicinity of Akron. Little information is available regarding the degree of hydraulic connection between unconsolidated valley-fill sediments and bedrock aquifers; however, Breen and others (1995) simulated groundwater flow from upland bedrock areas into sand- and gravel-filled valleys near Wooster with full horizontal and vertical hydraulic connectivity.

Well yields in the sands and gravels can be greater than $500 \mathrm{gal} / \mathrm{min}$ (Sedam, 1973; Ohio Department of Natural Resources, 2000c, 2000d). Fine-grained sediments found at the surface throughout the glaciated uplands and over some parts of the sand and gravel aquifers may serve as a protective barrier to the downward movement of contaminants into underlying aquifers; however, joints and fractures within these fine-grained sediments have recently been a focus of studies elsewhere in Ohio (Weatherington-Rice, 2004). Estimated hydraulic conductivity for the sand and gravel aquifers ranges from about 120 to more than $1,000 \mathrm{gal} / \mathrm{d} / \mathrm{ft}^{2}$ (16 to $\left.134 \mathrm{ft} / \mathrm{d}\right)$ with corresponding transmissivities ranging from 12,000 to $94,000 \mathrm{gal} / \mathrm{d} / \mathrm{ft}\left(1,600\right.$ to $12,600 \mathrm{ft}^{2} / \mathrm{d}$; Jones and others, 1958; Mayhew, 1985; Springer 1987; Garvey, 1988; Breen and others, 1995; Chowdhury and others, 2003). Aquifer porosity and specific yield data are scarce for sand and gravel aquifers in the Tuscarawas River Basin; however, published estimates from hydrology textbooks provide a range of porosity from 25 to 50 percent, whereas specific yields range from 10 to 30 percent (Domenico and Schwartz, 1990; Freeze and Cherry, 1979).

\section{Recharge}

The amount of water that recharges aquifers has been estimated by a number of different methods. The average value in the water budget presented above of 6 in. per year was derived by subtracting all estimated withdrawals and outflows from the known amount of rainfall that occurs in the area (Ohio Department of Natural Resources, 2008c). A recharge value also is included as one of the index variables in the groundwater pollution potential maps developed through 
the methods of Aller and others (1985). As of 2009, groundwater pollution potential maps for the Tuscarawas River Basin are available for all counties except Guernsey County and are referenced in appendix 1. These maps show that recharge varies as a function of meteorological conditions (including temperature and the type and intensity of precipitation), soil type, slope, and geology.

Breen and others (1995) estimated recharge in the Killbuck Creek Valley through groundwater-flow-model calibration to be about $5 \mathrm{in} / \mathrm{yr}$ in the uplands and as much as to $13 \mathrm{in} / \mathrm{yr}$ in the valleys. Breen and others (1995) also determined that a substantial amount of runoff from the bedrock uplands could not recharge the groundwater system in the uplands, but still recharged the sand- and gravel-filled valleys. (Breen and others (1995) used the term "rejected recharge" to describe this runoff). Bonta and Muller (1999) estimated annual, long-term groundwater recharge rates to be 5.5 to 15.4 in/yr, using a method devised by Glugla and Tiemer (1971). This method uses long-term average annual precipitation, runoff, potential evaporation, and crop-yield information along with a set of empirical parameter curves to derive recharge estimates. Dumouchelle and Schiefer (2002) used streamflow records and basin characteristics to estimate recharge rates at Sandy Creek of 9 to $10 \mathrm{in} / \mathrm{yr}$ and at Home Creek near New Philadelphia of 6 in/yr. Chowdhury and others (2003) estimated recharge of $14 \mathrm{in} / \mathrm{yr}$ within the outwash along Chippewa Creek in Wayne and Medina Counties.

\section{Source-Water Protection Areas}

To protect the quality of water derived from production wells and surface-water intakes, the Ohio EPA administers Ohio's Source Water Assessment and Protection Program (http://www.epa.state.oh.us/ddagw/pdu/swap_protection. $\mathrm{html}$ ). As of 2009, source-water areas have been defined for 10 public-supply water systems in or near the Tuscarawas River Basin (Ohio Environmental Protection Agency, 2009b; table 3). In another effort to protect groundwater supplies, the U.S. Environmental Protection Agency (2005) developed criteria to define aquifers as "Sole-Source Aquifers," specifying that they are a sole source of water and thereby require special protection status. As of 2009, there were no Sole-Source Aquifers within the basin and only four within Ohio. The nearest (and, perhaps, the most hydrologically similar to the Tuscarawas River Basin) designated Sole-Source Aquifer is the sand and gravel aquifer near Pleasant City in Guernsey County (just south of the basin), which was designated in 1987 (http://www. epa.state.oh.us/ddagw/Documents/SSA_pleasantcity_FR.pdf).

\section{Water Use}

Water-use estimates were summarized for two different geographic areas: the entire 13-county area that includes the Tuscarawas River Basin and for the 8-digit hydrologic unit code area of the Tuscarawas River Basin itself (05040001). Five categories of water-use were evaluated: public supply, domestic supply, agricultural (including livestock, aquaculture, and irrigation), industrial/mining, and thermoelectric power (U.S. Geological Survey, 2008c). For the 13 counties that encompass the Tuscarawas River Basin, total estimated water withdrawal in 2000 was $825 \mathrm{Mgal} / \mathrm{d}$ (table 4; U.S. Geological Survey, 2008c). (Data for the year 2000 were used here because, at the time of this publication, water-use estimates were available, but not published, for 2005.) The distribution of groundwater and surface-water use by county for 1985 , 1990,1995 , and 2000 is shown in figure 11. The most important change between years is the change from predominantly surface-water use in 1985 to predominantly groundwater use in 2000. This change can be attributed to the decrease of surface-water use due to the closing of major steel mills and other large water-using industries throughout the basin. Additionally, the distribution of water use is not consistent throughout the 13-county area. Coshocton and Belmont Counties used water at a rate an order of magnitude greater than any of the other counties because almost 68 percent of the total water used in the 13-county area was used for thermoelectric power in the form of cooling water for coal-fired power plants

Table 3. Source Water Assessment and Protection Program areas by county within the Tuscarawas River Basin, Ohio, on record with the Ohio Environmental Protection Agency as of 2009.

[From Ohio Environmental Protection Agency, 2009b; PWS, Public Water System]

\begin{tabular}{|c|c|}
\hline Public Supply Water System & Population served \\
\hline \multicolumn{2}{|c|}{ Belmont County } \\
\hline Belmont Co. Sanitary District 3 PWS & 24,387 \\
\hline Holloway PWS & 345 \\
\hline Shadyside PWS & 3,812 \\
\hline \multicolumn{2}{|c|}{ Coshocton County } \\
\hline Warsaw Village PWS & 890 \\
\hline \multicolumn{2}{|c|}{ Stark County } \\
\hline Aqua Ohio, Inc.-Massillon & 90,000 \\
\hline \multicolumn{2}{|c|}{ Summit County } \\
\hline Hudson City PWS & 5,750 \\
\hline \multicolumn{2}{|c|}{ Tuscarawas County } \\
\hline Dover City PWS & 13,570 \\
\hline New Philadelphia City PWS & 18,000 \\
\hline Wilkshire Hills PWS & 6,072 \\
\hline \multicolumn{2}{|c|}{ Wayne County } \\
\hline Wooster City PWS & 25,801 \\
\hline
\end{tabular}



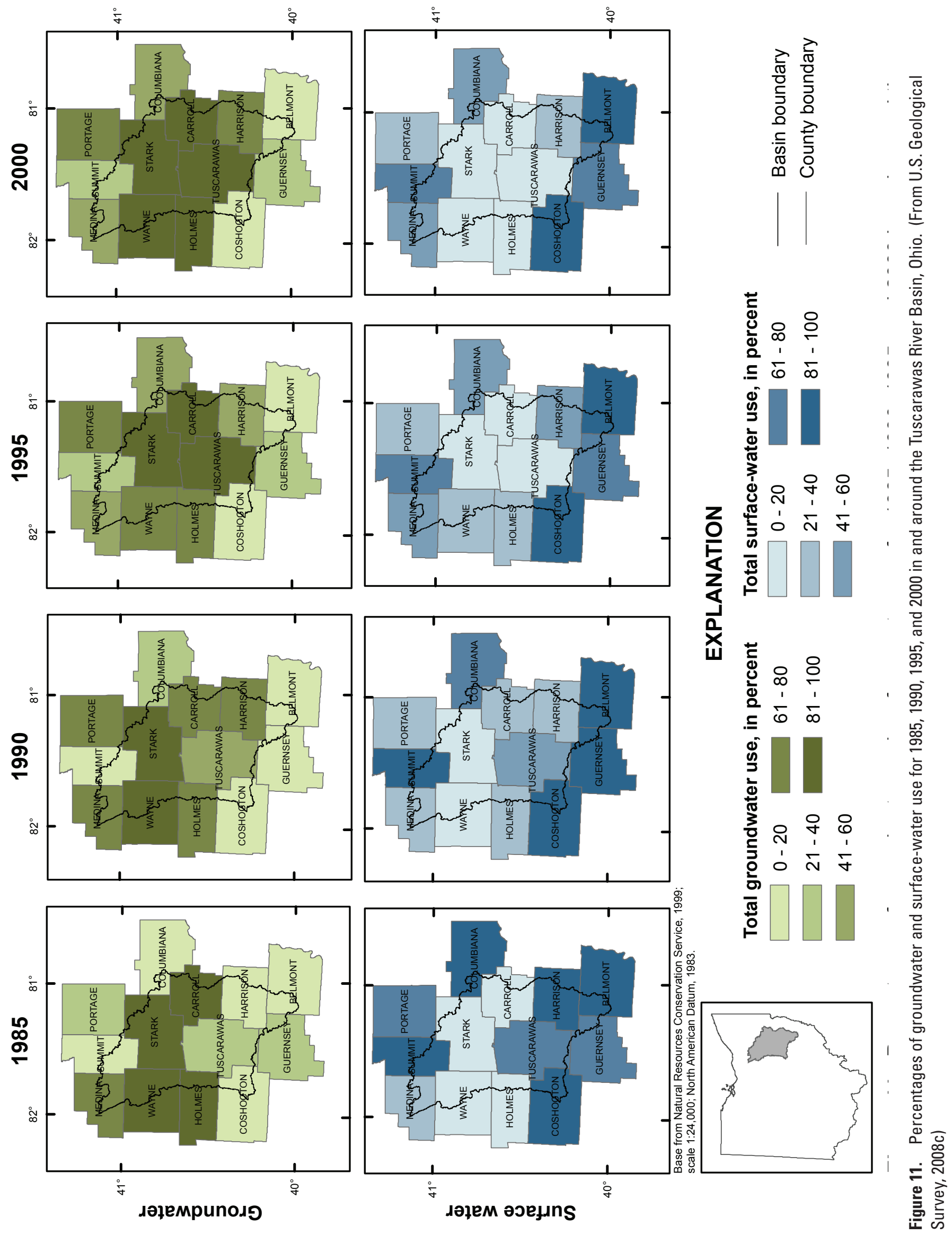
in these two counties (table 4; fig. 11). If water used for thermoelectric power water is excluded from this tabulation, as shown on the bottom of table 4, the dominant water use in all counties except Carroll County is public supply. (The dominant water use in Carroll County is domestic supply through private wells.) The 13-county water-use data are closely related to land-use data (table 2). Counties with higher populations and greater percentages of land use devoted to industry use greater quantities of water. Specifically, Stark and Summit Counties have the greatest population and withdraw the most water for public supply, industry, and mining, and these counties also have the greatest percentage of high-intensity urban development (which includes industrial land uses). Wayne County, which has the highest percentage of agricultural land use (75.1 percent in 2001), uses the greatest amount of water for agricultural purposes (2.0 Mgal/d; tables 2 and 4).

Water-use data for the Tuscarawas River Basin, which is defined by the 8 -digit hydrologic unit code 05040001 , were summarized using the same water-use categories described above; however, additional data were available to discriminate between groundwater and surface-water sources for four years (1985, 1990, 1995, and 2000; table 5). Total water-use values reported for the 13-county area are more than seven times those reported for the Tuscarawas River Basin area because some heavily populated areas lie just outside the basin boundary, but are still within the county. From 1985 to 2000, total groundwater use remained about the same, whereas surfacewater use declined from $82.5 \mathrm{Mgal} / \mathrm{d}$ in 1985 to $12.9 \mathrm{Mgal} / \mathrm{d}$

Table 4 Estimated total water use by water-use category in the counties that encompass the Tuscarawas River Basin, Ohio, 2000.

[Modified from U.S. Geological Survey, 2008c; Mgal/d, million gallons per day; rows may not add up to 100 percent due to rounding; na, not applicable]

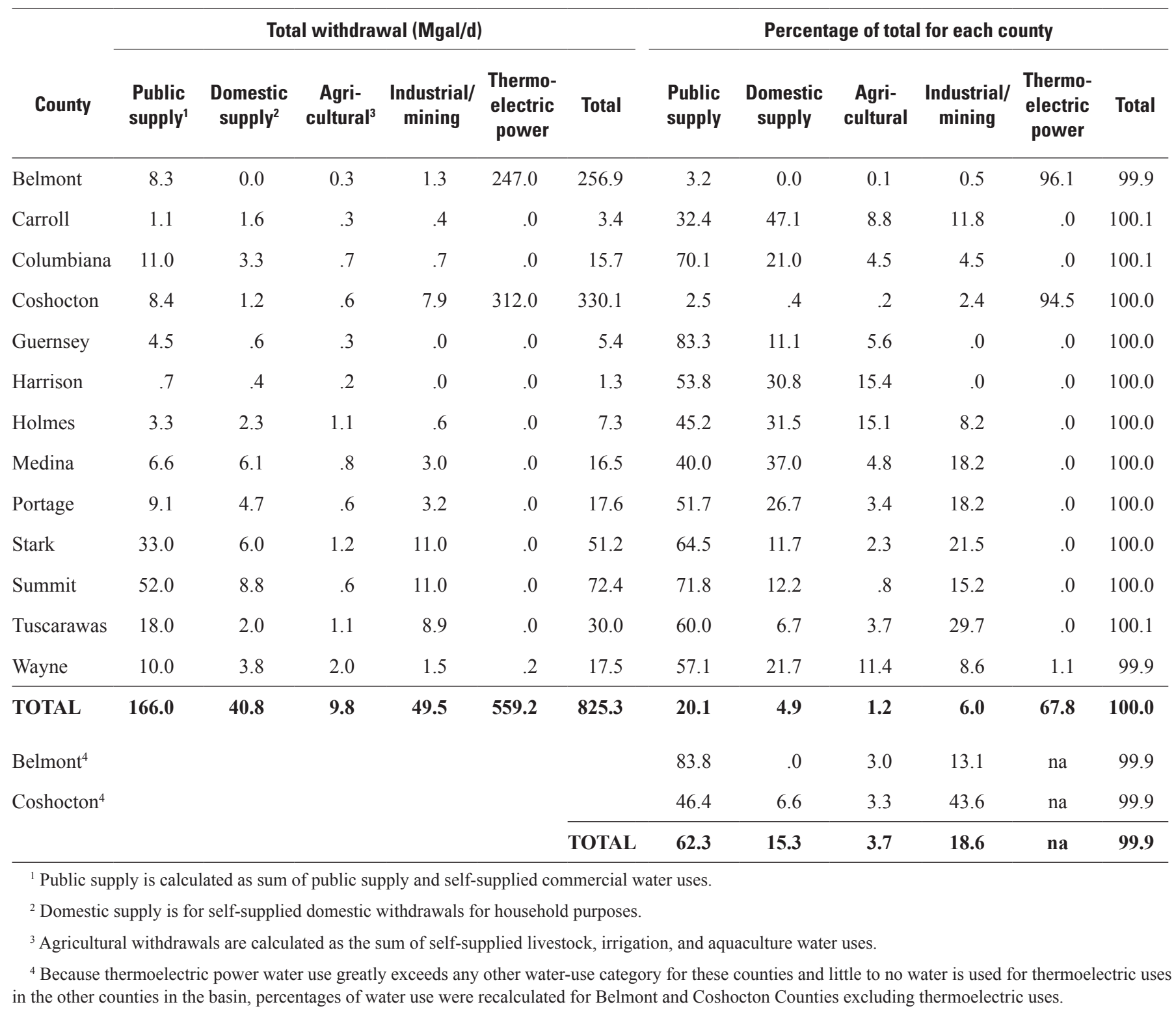


in 2000 (table 5). As noted above, the decline in surface-water use is attributable primarily to decreases in industrial uses and likely reflects the closing of steel mills in the late 1980s. Overall, total water use over the 16-year period declined by almost 37 percent from $183 \mathrm{Mgal} / \mathrm{d}$ in 1985 to $116 \mathrm{Mgal} / \mathrm{d}$ in 2000 .

\section{Water Quality}

Water quality in a stream or reservoir, or within an aquifer, can be affected by natural processes and human activities. As noted in Hem (1985), the primary natural processes that affect water quality are interaction with the atmosphere, weathering and erosion of rocks and soil, and chemical reactions occurring below land surface. Some minerals, such as quartz, are relatively inert and may not contribute chemicals to water; however, other minerals, such as gypsum, pyrite, and calcite, readily dissolve and contribute elements such as calcium, sulfur, and iron to water. Within the Tuscarawas River Basin, the primary human activities that affect water quality are agriculture, mining, oil and gas drilling, waste disposal, and many industrial activities. Taste, odor, and appearance usually are the most commonly cited issues regarding degraded water quality, but dissolved chemicals at concentrations lower than humans can detect by their senses alone may cause health issues.

The earliest publications specifically related to waterquality information from the Tuscarawas River Basin typically provided data only on the basic properties of water or concentrations of major elements related to drinking-water supplies (see, for example, Stout and others, 1943; Cummins and Sanderson, 1947; Ohio River Valley Water Sanitation Commission, 1951). These reports focus on water temperature and concentrations of calcium, magnesium, iron, sulfate, dissolved oxygen, and suspended sediment. Prior to the 1940s, most groundwater was distributed untreated, and the only treatment for Tuscarawas River Basin surface water was filtration (Stout and others, 1943). One of the earliest reports to describe a specific source of degraded water quality is by Harker and Bernhagen (1943a) who noted stream contamination and intrusion of saltwater and oil into aquifers due to oil and gas production in the Chatham oil field area (Medina County). After about 1960, reports by Ohio Water Commission (1960), Thomas (1960), Ohio Department of Natural Resources (1968), and the Ohio Drilling Company (1971) document additional waterquality issues related to agricultural practices, mining of coal and salt, and industry. This period also coincided with rapid improvements in the ability to accurately and precisely measure concentrations of dissolved chemicals in water.

Regional studies of water quality in the Tuscarawas River Basin by the Ohio Department of Health (1958), Weston (1968), the Ohio Department of Health and Ohio Water Pollution Control Board (1968), and the Ohio Department of Natural Resources (1971 and 1978b) document wide-spread surface-water-quality issues related to municipal wastes, industrial wastes, organic pollution, and chloride contamination from salt mining and chemical processing. Another regional-scale water-quality study was done by the U.S. Environmental Protection Agency (1978) as part of the National Eutrophication Survey. This report provides summary data for Atwood Lake, Beach City Lake, and Tappan Lake that include morphology (drainage area, surface area, mean depth, total inflow, and retention time), physical and chemical characteristics (alkalinity, specific conductance, Secchi disk depth, phosphorus, orthophosphate, inorganic nitrate, and total nitrate), biological characteristics (chlorophyll $a$, algae, and phytoplankton), nutrient loadings, and nonpoint source nutrient export.

Examples of surface-water inventories for water quality and (or) biology on smaller scales include those done by Prée (1962a, c); Ohio Department of Natural Resources (1972, 1974a, 1974b); Northeast Ohio Four County Regional Planning and Development Organization for the Upper Tuscarawas

Table 5. Estimated groundwater and surface-water use for the Tuscarawas River Basin, Ohio, 1985-2000.

[Tuscarawas River Basin is defined by the 8-digit hydrologic unit code 05040001; data modified from U.S. Geological Survey, 2008c; all values are in million gallons per day; GW, groundwater; SW, surface water; T, total]

\begin{tabular}{|c|c|c|c|c|c|c|c|c|c|c|c|c|c|c|c|c|c|c|}
\hline \multirow[b]{2}{*}{ Year } & \multicolumn{3}{|c|}{$\begin{array}{l}\text { Public } \\
\text { supply }\end{array}$} & \multicolumn{3}{|c|}{$\begin{array}{l}\text { Domestic } \\
\text { supply }^{2}\end{array}$} & \multicolumn{3}{|c|}{ Agricultural $^{3}$} & \multicolumn{3}{|c|}{$\begin{array}{l}\text { Industrial / } \\
\text { mining }\end{array}$} & \multicolumn{3}{|c|}{$\begin{array}{c}\text { Thermoelectric } \\
\text { power }\end{array}$} & \multicolumn{3}{|c|}{ Total } \\
\hline & GW & SW & $\mathbf{T}$ & GW & SW & $\mathbf{T}$ & GW & SW & $\mathbf{T}$ & GW & SW & $\mathbf{T}$ & GW & SW & $\mathbf{T}$ & GW & SW & $\mathbf{T}$ \\
\hline 1985 & 58.0 & 6.8 & 64.8 & 21.0 & 0.0 & 21.0 & 2.5 & 1.7 & 4.2 & 0.2 & 52.0 & 52.2 & 19.0 & 22.0 & 41.0 & 100.7 & 82.5 & 183.2 \\
\hline 1990 & 38.0 & 28.0 & 66.0 & 18.0 & .4 & 18.4 & 1.3 & 2.4 & 3.7 & 12.0 & 10.0 & 22.0 & .1 & .0 & .1 & 69.4 & 40.8 & 110.2 \\
\hline 2000 & 55.0 & 7.2 & 62.2 & 17.0 & .4 & 17.4 & 2.0 & 2.3 & 4.3 & 29.0 & 3.0 & 32.0 & .2 & .0 & .2 & 103.2 & 12.9 & 116.1 \\
\hline
\end{tabular}

${ }^{1}$ Public supply is calculated as sum of public supply and self-supplied commercial water uses.

${ }^{2}$ Domestic supply is for self-supplied domestic withdrawals for household purposes.

${ }^{3}$ Agricultural withdrawals are calculated as the sum of self-supplied livestock, irrigation, and aquaculture water uses. 
River Basin (1985, 1999a, 2004), for Upper Wolf Creek (1999c), and for Nimishillen Creek (2001b, 2003, 2005); Dai (1993); Ohio Environmental Protection Agency (1996c, 2003, 2005); Wellman (1998); Gannett Fleming (2000); Carroll County Regional Planning Commission (2004); Akin (2006); U.S. Environmental Protection Agency (2006c); and Huff Run Watershed Restoration Partnership (2006a, b, c). These studies document cases of contamination of water, sediment, and soils due to agriculture, mining, and chemical spills, with specific reference to nutrients, metals, chloride, and a number of organic compounds (including gas, oil, volatile organic compounds, and solvents).

Water-quality inventories of lakes and reservoirs in the basin include those by Tobin and Youger (1979) and Davic and others (1997). Tobin and Youger (1979) report that most lakes in the Tuscarawas River Basin (and throughout Ohio) are shallow (less than $17 \mathrm{ft}$ deep) and, as a result, do not develop stratification and are generally of poor water quality. Tobin and Youger (1979) also note that nitrate and phosphorus concentrations were characteristically high in all lakes. Davic and others (1997) detected lindane (an insecticide) in the waters of Atwood Reservoir and Tappan Lake and dieldrin (another insecticide) in Nimisila Reservoir. As noted above, interaction between groundwater and lakes and reservoirs has not been examined in the Tuscarawas River Basin.

Within the past few decades, biological indices that enumerate the species and general health of aquatic organisms have replaced some of the more traditional chemical analyses (see, for example, Hyland, 1982; McShaffrey and Olive, 1985; Barber and others, 1997; March, 2002; and numerous Ohio Environmental Protection Agency studies published from 1978 through 2006). The Ohio Environmental Protection Agency also has done many studies on water quality with special attention given to aquatic insects, amphibians, and fish, including those for Nimishillen Creek (Ohio Environmental Protection Agency, 1994a, 2001); River Styx (Ohio Environmental Protection Agency, 1994b); parts of the Upper Tuscarawas River, Wolf Creek, and Hudson Run (Ohio Environmental Protection Agency, 1994c); Upper Sandy Creek and Still Fork Sandy Creek (Ohio Environmental Protection Agency, 1995a); parts of the Tuscarawas River and Sugar Creek (Ohio Environmental Protection Agency, 1995b); Upper Killbuck Creek (Ohio Environmental Protection Agency, 1996b); Upper Muskingum River (Ohio Environmental Protection Agency, 1996c), Sandy Creek (Ohio Environmental Protection Agency, 1998a); and Sugar Creek (Ohio Environmental Protection Agency, 1998b, 2006d, 2006e). Results of these studies specifically describe the effects of agriculture and industry with regard to impaired aquatic habitat.

The U.S. Environmental Protection Agency (2006a) provided summary data for the status of stream segments in 2002 and 2004. The two datasets show that 10 out of 18 assessed stream segments were listed as impaired in 2002, whereas only 1 of 11 stream segments was listed as impaired in 2004. Although not all of the same stream segments were evaluated during these two studies, these data indicate that, overall, the fraction of sites that were impaired during this time period decreased and that water quality has been improving.

The Ohio Environmental Protection Agency conducted integrated biological studies of fish and amphibians (Ohio Environmental Protection Agency 2002b, 2004, 2006b) and issued sport-fish advisories based on these findings (Ohio Environmental Protection Agency, 2006c). The results of these studies show that the tissue of some fish species in the basin contained elevated concentrations of polychlorinated biphenyls (PCBs) and hexachlorobenzene, requiring advisories that recommend limited fish consumption by humans.

As of 2009, 29 organisms (24 animals and 5 plants) were listed by the U.S. Fish and Wildlife Service (2009b) as threatened or endangered species within Ohio. The only aquatic organisms on this list within the Tuscarawas River Basin were several species of mussels.

\section{Effects of Land Use}

Agriculture and mining are probably the most often cited land-use practices that have documented wide-spread effects on water quality in the basin (Ohio Department of Health and Ohio Water Pollution Control Board, 1968; Northeast Ohio Four County Regional Planning and Development Organization, 1985; Razem and Sedam, 1985; Sedam, 1991; and Sedam and Francy, 1993). Agriculture includes the clearing and preparation of land for growing crops; application of fertilizers, pesticides, and manure; raising of farm animals; and delivery of medicines (including hormones and antibiotics) to these animals. Fertilizers contain nutrients such as nitrogen and phosphorous which commonly enter drainage ditches and groundwater and result in algal blooms in surface-water bodies, such as those documented by Olive and Higgins (1981) and Hambrook and others (1999). Nutrients and pesticides are linked not only to agriculture, but also to residential areas where homeowners apply fertilizers and pesticides to their lawns and gardens. Elevated nutrients have been noted in water from Wayne County (Beck and others, undated a) and Coshocton County (Golden and others, undated a), and within the Sugar Creek Watershed (Parker and Webb, 2006). Prasad and others (2005) examined hydrologic and land characteristics in the Sugar Creek Watershed in relation to nutrient loads and concluded that nitrate concentrations paralleled precipitation patterns over time as a result of transport of land-applied fertilizers in stormwater, with high nitrate concentrations corresponding to high precipitation; however, only 35 percent of the nitrate load could be attributed to stormwater alone. The work also revealed correlations of nitrate, ammonia, and phosphate with geomorphologic characteristics, such as elevation and slope.

As with agriculture, much of the basin was (and continues to be) involved in coal mining. Prior to 1977 and the passage of the Surface Mining Control and Reclamation Act (Office of Surface Mining, 2009), there were no requirements to reclaim coal mines, and as a result, land was most often abandoned after the coal was removed. Through coal mining, 
pyrite (a common iron sulfide mineral associated with coal) is exposed to the atmosphere and reacts with water and oxygen. This process, known as pyrite oxidation, releases iron and sulfur into streams and groundwater. The iron and sulfur further react with water and oxygen to decrease $\mathrm{pH}$, causing acid mine drainage. Regional studies of groundwater quality done by Prée (1962b), Engelke and Roth (1981), Majchszak (1984), Razem and Sedam (1985), Sedam (1991), Sedam and Francy (1993), and Breen and others (1995) indicate that most aquifers in the basin contain elevated concentrations of iron and manganese, due in part to the effects of coal mining. The legacy of coal mining also can be seen in many streams with low $\mathrm{pH}$, excess sedimentation, and precipitation of iron hydroxides (also known as "yellow boy") on stream beds, all of which often lead to degraded habitat for aquatic biota. Also, contamination from trace elements (such as arsenic) derived from coal and coal-combustion byproducts may cause water-quality concerns in some areas (Knapp, 1977; Khourey, 1981; Matisoff and others, 1981; Matisoff and others, 1982; Haefner, 2002).

A secondary source of impaired water quality related to the mining of coal comes from coal combustion and gaseous emissions of sulfur, nitrogen, carbon, and mercury (Heit, 1985; Walk and Godfrey, 1990). The National Atmospheric Deposition Program (http://nadp.sws.uiuc.edu/) monitors atmospheric deposition throughout the United States, and although the quantity of atmospheric discharges has decreased since 1980 (U.S. Environmental Protection Agency, 2008b), eastern Ohio remains one of the largest producers of gaseous emissions that affect not only the Tuscarawas River Basin, but much of the northeastern United States.

As noted in the previous section on geology, substantial quantities of salt lie in thick beds thousands of feet below the surface in the basin. The briny solutions generated during salt mining are typically pumped into large ponds for evaporation to remove the water. Historically, these ponds were often unlined, and the salt solution leaked into groundwater and surface water, causing chloride contamination in areas such as Barberton in Summit County. The effects of this contamination have been observed great distances downstream over long periods (Ohio River Valley Water Sanitation Commission, 1951; Lamborn, 1952; Ohio Department of Health, 1958; Jones, 1961; Rau, 1972, 1974; Williams, 1973).

The other human activities related to land use in the Tuscarawas River Basin that have been documented to affect water quality include industry, transportation, wastewater facilities, domestic septic systems, and waste-disposal landfills. Major industrial activities in the basin include steel mills, petroleum refineries, and chemical plants. The presence of volatile organic compounds (VOCs) in water and sediments has been documented in Stark County (Stark County Health Department, 2005; Oelker and others, undated a), Summit County (Oelker and others, undated b), and Tuscarawas County (Ohio Environmental Protection Agency, 1995b, 1996a, 1998a), and VOCs in trace amounts are present throughout the Tuscarawas River Basin (Richards and
Wellrabenstein, 1995; Zbasnik, 1996). Pre-regulation industrial liquid-waste disposal practices are described in Clifford (1975); however, these practices are currently regulated by the Ohio Environmental Protection Agency (http://www.epa. state.oh.us/ddagw/uic.html). Other documented discharges are reported to, and recorded by, the Ohio Environmental Protection Agency and are available by contacting the Ohio Environmental Protection Agency Division of Emergency and Remedial Response.

The effects of transportation corridors and problems associated with gaseous emissions, leaking oil and gas, road salt, and road debris have not been specifically evaluated in the Tuscarawas River Basin, but similar settings throughout Ohio and the United states have experienced water-quality degradation related to these issues (see, for example, Mahler and others, 2005; Rogge and others, 1993). Because the Ohio Department of Transportation and county and local governments within the Tuscarawas River Basin apply road salt to minimize hazards associated with freezing roadways, localized issues related to chloride contamination can occur (Ohio Environmental Protection Agency, 1999). For example, Kunze and Sroka (2004) document short-term road-salt contamination in groundwater along State Route 14 in Portage County (just north of the Tuscarawas River Basin).

Wastewater facilities in Ohio and the Tuscarawas River Basin are regulated with respect to the quantity and quality of their discharge of contaminants to the environment, but inadequate designs and combined use of stormwater systems for routing stormwater runoff may lead to substantial discharge of untreated wastewater to surface-water bodies. Furthermore, poorly designed domestic septic systems and poor soil drainage may cause local groundwater and surface-water contamination. Specific data regarding the number of households using septic systems were not available at the time of this publication; however, Akin (2006) estimated that over half of the Nimishillen Creek Watershed was unsewered in 2006. Richards and Wellrabenstein (1995) collected groundwater samples that had elevated concentrations of ammonia, sodium, barium, and strontium in alluvial deposits in Coshocton County, indicative of water softening and septic-tank effluent. Dumouchelle (2006) described contamination of groundwater by bacteria and elevated nitrate concentrations related to septic-system discharges in Wayne County, near Wooster.

Solid-waste disposal in sanitary and other types of landfills is regulated by the Ohio Environmental Protection Agency Division of Solid and Infectious Waste Management (http://www.epa.state.oh.us/dsiwm/). In 2009, the accepted method of landfill development is to construct a lined basin where waste is deposited and covered. In the past, however, liners were not required and unknown types and quantities of waste may have been placed and buried in landfills. Studies related to solid-waste disposal in the Tuscarawas River Basin have been done for the Industrial Excess Landfill near Uniontown (Bair and Norris, 1989; Jackson and others, 1989; Dumouchelle and Bair, 1994) and for the Hardy Road Landfill in Akron (Jackson and others, 1989). 
Through the movement of air or water, activities in one part of the basin may affect water quality in another part of the basin. For example, the aforementioned chloride contamination from salt mining and other industrial activities in the upper part of the basin have been traced through the entire downstream extent of the Tuscarawas River from Barberton to Coshocton (Cummins and Sanderson, 1947; Ohio Department of Health, 1958; Rau 1972, 1974). To examine downstream movement of contaminants in the Tuscarawas River, Westfall and Webber (1977) added fluorescent dye to the Tuscarawas River downstream from Barberton and traced the dye 106 miles to Coshocton. The leading edge of the dye reached Coshocton after about 119 hours and the peak concentration of the dye plume arrived in about 137 hours.

\section{Total Maximum Daily Loads}

The Ohio Environmental Protection Agency implemented the Total Maximum Daily Load (TMDL) program to address some of the water-quality issues in Ohio and the Tuscarawas River Basin (http://www.epa.state.oh.us/dsw/tmdl/). The TMDL program “...is a written, quantitative assessment of water quality problems in a water body and contributing sources of pollution. It specifies the amount a pollutant needs to be reduced to meet water quality standards (WQS), allocates pollutant load reductions, and provides the basis for taking actions needed to restore a water body." As of 2009, the Ohio Environmental Protection Agency has completed three TMDL projects within the Tuscarawas River Basin, two for the Sugar Creek Watershed and one for Nimishillen Creek. For Sugar Creek, the first focuses on aquatic life (Ohio Environmental Protection Agency, 2002d) and the second on recreational use of water related to bacteria (Ohio Environmental Protection Agency, 2006d). For Nimishillen Creek, the TMDL focuses on sediment and bacteria (Ohio Environmental Protection Agency, 2009c). At the time of this publication, the TMDL report for the mainstem of the Tuscarawas River was published and available for comment in draft form (Ohio Environmental Protection Agency, 2009d. The preliminary findings from the data collected between 2003 and 2005 are that, overall, the condition of the watershed was fair to good with respect to goals associated with healthy warm-water habitat. The lower section of the watershed displayed exceptional quality, whereas the upper portion of the watershed generally had lower water quality due to more intense land use. The Ohio Legislature established the Acid Mine Drainage Abatement and Treatment (AMDAT) fund in 1995, which is similar to the TMDL program, to provide for the long-term restoration of watersheds biologically impaired by acid drainage derived from abandoned coal mines. Within the Tuscarawas River Basin, Huff Run is the first subbasin for which an AMDAT plan was established (Gannett Fleming, 2000).

\section{Hydrologic Data Networks}

As of 2009, there were many different types of hydrologic data collected within the Tuscarawas River Basin from many different sources. The hydrologic data assessment presented here focuses on long-term and regularly scheduled data-collection activities; however, there also are many other data-collection efforts that were done on an as-needed basis or were done independent of a recurring program. For the purposes of this report, hydrologic data include measurements associated with water levels, chemical quality, and biologic characteristics related to meteorology, surface water, and groundwater. This section of the report focuses on data-collection networks that were recently active or active during 2009 that provide insight concerning the goals and priorities of the data-collecting organizations operating in the basin.

The primary entities responsible for hydrologic data collection throughout the basin (listed in alphabetical order) are the Muskingum Watershed Conservancy District, the National Weather Service, the Ohio Department of Health, the Ohio Department of Natural Resources, the Ohio Environmental Protection Agency, the U.S. Army Corps of Engineers, and the U.S. Geological Survey. A substantial amount of hydrologic information also is collected by county agencies, watershed groups, and local groups, such as the Northeast Ohio Four County Regional Planning and Development Organization, which focuses on Portage, Stark, Summit, and Wayne Counties. Hydrologic data also are collected by private consulting firms and academia; however, these data are generally unavailable to the public or may be difficult to obtain or integrate because they are either the private property of clients or they are in printed form only and are not generally included in regional or state-wide databases.

For this report, a library of datasets that contain spatial and attribute information (such as biology, data-collection stations, geology, hydrology, land use, population, and topography) related to the Tuscarawas River Basin was created in a geographic information system (GIS) geodatabase format. A geodatabase contains spatial information and supports multiple data formats including vector, raster (grid- or cell-based), and tabular information, as well as images and metadata. The database is available upon request from the USGS Ohio Water Science Center.

\section{Meteorology}

Meteorological stations within the Tuscarawas River Basin are shown in figure 12. The only three National Weather Service stations (shown as black squares in figure 12) in or near the basin are at the Akron-Canton Airport, the Wayne County Airport near Wooster, and Harry Clever Field in New Philadelphia; however, several additional National Weather Service stations are located near the basin boundaries and are not shown in figure 12, including those at Wheeling (West Virginia), Youngstown, Mansfield, Zanesville, and 


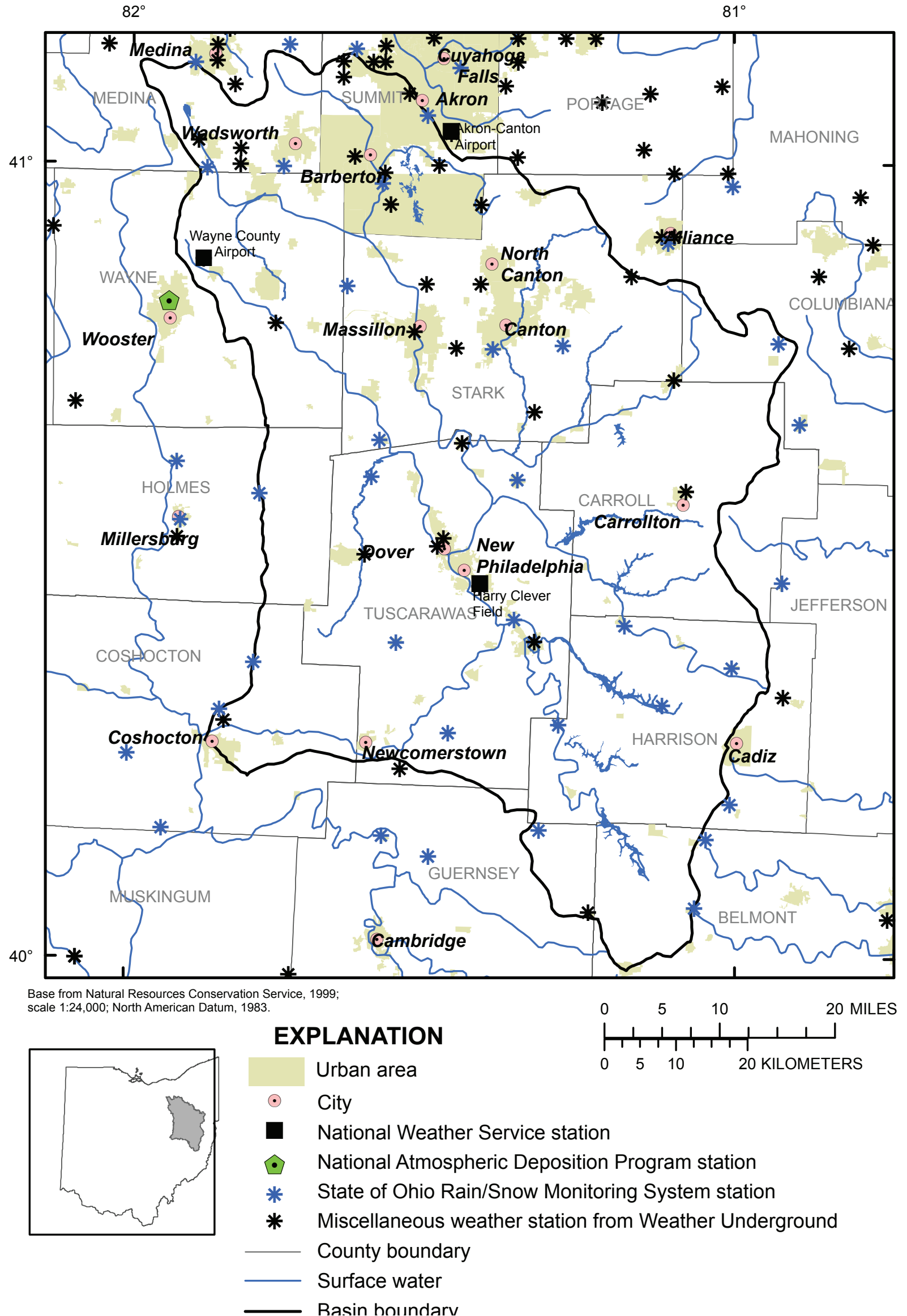

Figure 12. Locations of meteorological stations in and around the Tuscarawas River Basin, Ohio. 
Lancaster (Ohio). The National Atmospheric Deposition Program (http://nadp.sws.uiuc.edu/), which is operated by the Ohio Agricultural Experiment Station, U.S. Geological Survey, U.S. Department of Agriculture, and numerous other government and private entities, collect and analyze precipitation samples for hydrogen (acidity as $\mathrm{pH}$ ), sulfate, nitrate, ammonium, chloride, calcium, magnesium, potassium, and sodium. Although there are no National Atmospheric Deposition Program stations in the Tuscarawas River Basin, there are six stations within Ohio: the closest two are in Wooster (Wayne County) and Caldwell (Noble County, not shown on figure 12).

In response to a catastrophic flood in eastern Ohio in 1990, the Ohio Emergency Management Agency developed a flood-warning system that provided for the establishment of a monitoring system to measure rain and snowfall in each of Ohio's 88 counties as part of the State of Ohio Rain/Snow Monitoring System (STORMS). The original recommendations were for the State to install and operate at least five automated rain gages in each county. As of 2009, there were 288 rain gages in Ohio listed on the Wilmington National Weather Service Web site (http://www.afws.net/states/oh/oh.htm), 49 of which are within 10 of the 13 counties that encompass the Tuscarawas River Basin. There were no stations in Carroll, Portage, or Wayne Counties. The Web site notes that installation of additional stations is prioritized by river basin, topographic characteristics, and the population at risk.

The Weather Underground (on http://www.wunderground. $\mathrm{com} /$ ) is a commercial, Internet-based weather reporting system that incorporates many different sources of weather data from throughout the world. This system allows individuals to establish their own weather station and provide weather data through the Internet interface. Typical data from this network include temperature, dew point, humidity, wind speed and direction, barometric pressure, and precipitation amount. In and around the Tuscarawas River Basin, approximately 50 weather stations are included in this network and are shown as "miscellaneous weather stations" on figure 12 (some of these sites may be the same as sites in the STORMS network described above).

\section{Surface Water}

The surface-water data-collection efforts described in this section are limited to stage (stream and reservoir levels) and streamflow, flood-related data, and data collected to operate dams. The primary agencies and groups that collect surfacewater data are the Ohio Department of Natural Resources, the Ohio Environmental Protection Agency, the U.S. Army Corps of Engineers, and the U.S. Geological Survey. Additional datacollection activities related to water quality and biological assessments at surface-water sites are described in the "Water Quality" section. Watershed groups within the Tuscarawas River Basin also collect a substantial amount of surface-water related data. As of 2009, there were 11 watershed groups in the basin (table 6). Links to each of these watershed groups along with contacts and profile information are available on the Ohio State University Extension Web page (http://ohiowatersheds. osu.edu/groups/wgp_all.php). An example of some of the data collected and work done by watershed groups is provided by Moore (2006) for Sugar Creek. The report describes a community-based approach to management of water resources and focuses on work at the local level. Additional reports by watershed groups related to watershed planning are listed in appendix 1 under "Hydrology/Watershed Planning."

Table 6. Watershed groups in the Tuscarawas River Basin, Ohio.

[Modified from http://ohiowatersheds.osu.edu/groups/wgp_all.php]

\begin{tabular}{ll}
\hline \multicolumn{1}{c}{ Watershed group } & \multicolumn{1}{c}{ Watershed } \\
\hline East Branch Sugar Creek Watershed & Sugar Creek. \\
Enviro Outreach Organization & Tuscarawas River. \\
Huff Run Watershed Restoration Partnership, Incorporated & Huff Run. \\
Little Beaver Creek Land Foundation & Little Beaver Creek. \\
Nimishillen Creek Watershed Partners & Nimishillen Creek. \\
North Fork Task Force & Sugar Creek. \\
Portage Lakes Advisory Council & Portage Lakes. \\
Tuscarawas River Buried Valley Watershed Council & Tuscarawas River. \\
Upper Sugar Creek Farmer Partners & Upper Sugar Creek. \\
Upper Tuscarawas River Technical Advisory Committee & Upper Tuscarawas River. \\
Upper Wolf Creek Technical Advisory Committee & Upper Wolf Creek. \\
\hline
\end{tabular}




\section{Stage and Streamflow}

Within the Tuscarawas River Basin, stage and streamflow data have been obtained from a network of streamgages operated and maintained by the U.S. Geological Survey, in cooperation with the U.S. Army Corps of Engineers, the Ohio Department of Natural Resources, and the Ohio Environmental Protection Agency (fig. 13). As of 2009, the U.S. Geological Survey National Water Information System database (http://waterdata.usgs.gov/oh/nwis/) contained records for 699 surface-water sites in the Tuscarawas River Basin; however, many of these sites have been discontinued or represent a location where only a single measurement or a few measurements were made. Within the basin, there were 17 real-time streamgages in 2009; 9 of these gages report stage and discharge data, and the remaining 8 gages report stage only. The Ohio River Valley Water Sanitation Commission collects data within the Muskingum River Basin but focuses on the main tributaries to the Ohio River and not on upstream sources (such as the Tuscarawas River).

The stages of lakes and reservoirs are recorded by the U.S. Army Corps of Engineers (2008) Huntington District and include current pool-height and elevation, outflow temperature, and precipitation in the last 24 hours. As of 2009, there were eight sites providing these data at Atwood, Beach City, Bolivar, Clendening, Dover, Leesville, Piedmont, and Tappan Lakes (fig. 13). Although the U.S. Geological Survey also collects stage data for lakes and reservoirs, there are only seven such sites in Ohio, and none of these are within the Tuscarawas River Basin.

\section{Floods}

The National Oceanic and Atmospheric Administration's Advanced Hydrologic Prediction Services provides summaries of streamflow data (obtained in cooperation with the U.S. Geological Survey), precipitation data, and predictions of flood stages in rivers (National Oceanic and Atmospheric Administration, 2008). The Web site displays the predicted magnitude and uncertainty of occurrence of floods or droughts. For stream reaches where no gage data are available, Koltun (2003) and Koltun and others (2006) provide multiple regression equations that can be used to estimate flood peak discharges of rural unregulated streams. Koltun and Sherwood (1998) developed a method to evaluate the joint probability of flooding between/on/ two streams (for example, a tributary and receiving stream) or stream segments and included Sandy Creek, Middle Branch Nimishillen Creek, Nimishillen Creek, and Home Creek in their analyses.

\section{Dams}

Large amounts of data are collected on and adjacent to dams throughout the basin. The eight dams operated by the U.S. Army Corps of Engineers are the largest dams in the basin (fig. 13). In Ohio, dams are classified by size and whether or not failure may result in loss of human life (Ohio Department of Natural Resources, 2008a). For example, Class I dams have a total storage volume greater than 5,000 acrefeet or a height greater than 60 feet. Sudden failure of a Class I dam probably would result in loss of human life and (or) structural collapse of at least one residence or one commercial or industrial business. In the Tuscarawas River Basin, there are more than 2,700 dams, 187 of which are Class I dams. The Ohio Department of Natural Resources, Division of Water Dam Safety, and the U.S. Army Corps of Engineers are the two primary entities in Ohio responsible for dam inspections, maintenance, and repair.

The U.S. Army Corps of Engineers Muskingum River Basin Systems Operation Study (U.S. Army Corps of Engineers, 2006a) identified several problems related to the dams and reservoirs in the Muskingum River Basin, including “... aging infrastructure (hydrologic deficiency, seepage and foundation problems, outlet tunnel deterioration, gate deterioration, spillway erosion, relief wells, and related facilities), reservoirs/ lakes (reservoir operations, sedimentation and flood storage loss, lake quality, and conflicts among project purposes), and watershed problems (ecosystem degradation, acid mine drainage, residual flood damages, flood plain development, water and sewer infrastructure needs)."

\section{Groundwater}

Groundwater data-collection sites include observation wells, domestic wells, and production wells. The first groundwater-level network in Ohio was started for the Ohio Water Supply Board in the early 1940s (Harker, 1943b); however, earlier water-level data from non-routine measurements also are available, including data from the Ohio Department of Natural Resources, which began recording water levels in 1938 .

\section{Water Levels}

As of 2009, water levels were recorded on a regular basis throughout the State by the Ohio Department of Natural Resources Division of Water, in cooperation with the U.S. Geological Survey. Hourly water-level data are reported on http://www.dnr.state.oh.us/water/waterobs/obs_well_map. $a s p$, and the U.S. Geological Survey reports most of the same data on http://waterdata.usgs.gov/oh/nwis/gw. Within the Tuscarawas River Basin, 27 wells were instrumented to record daily maximum depths to water (fig. 14). These data were recorded with data loggers and were downloaded and transferred to the Ohio Department of Natural Resources and the U.S. Geological Survey databases on an annual basis. Two additional sites outside of the basin (PO-124 in Portage County and WN-8 in Wayne County) provided real-time data transmitted through satellite telemetry (http://waterdata.usgs. gov/oh/nwis/current/?type $=$ gw). In addition to water levels, 


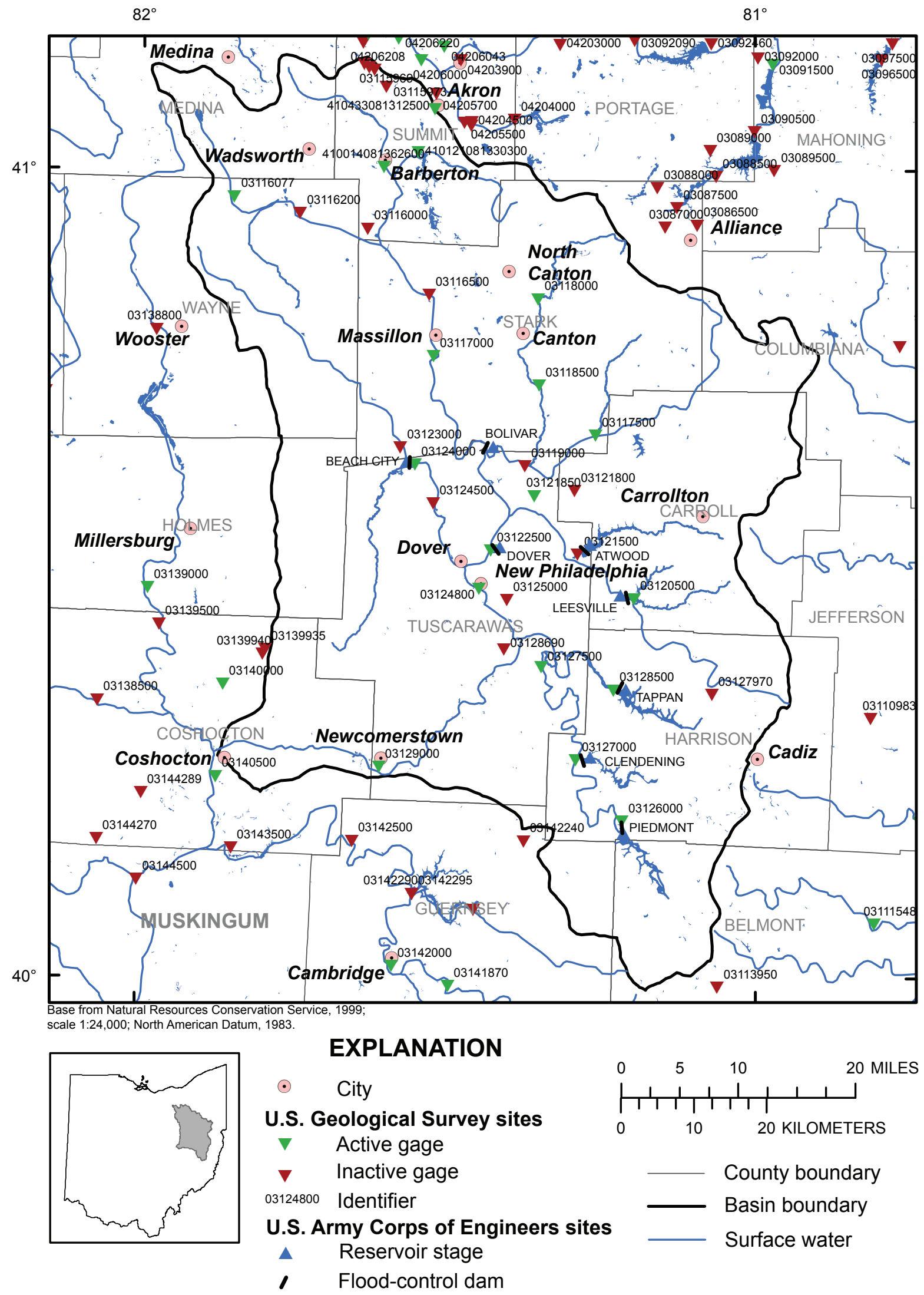

Figure 13. Locations of surface-water data-collection sites in and around the Tuscarawas River Basin, Ohio. 


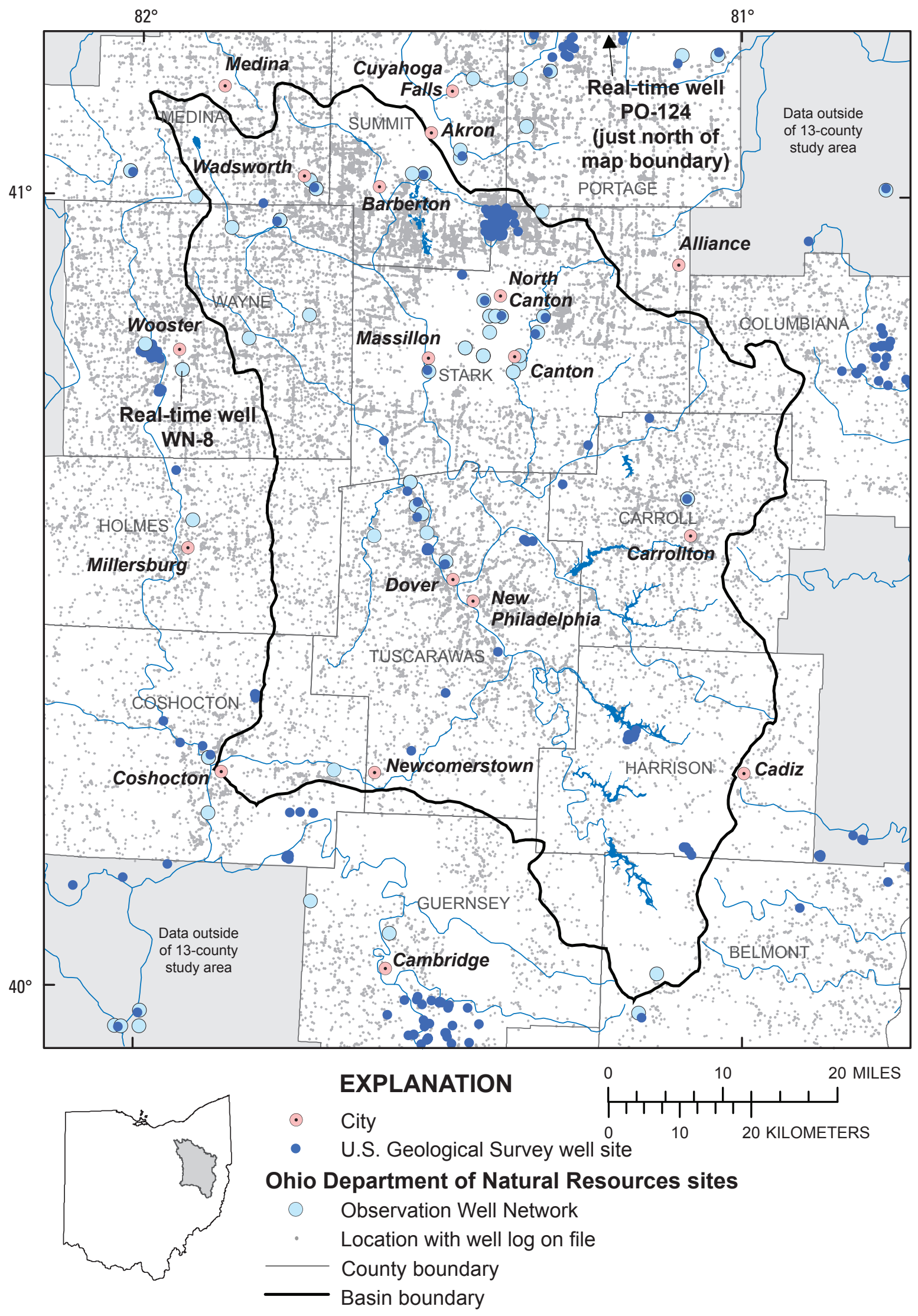

Figure 14. Locations of groundwater data-collection sites in and around the Tuscarawas River Basin, Ohio. 
both the Ohio Department of Natural Resources and U.S. Geological Survey Web sites provide well characteristics (including well depth, aquifer, casing diameter, screen interval) and long-term hydrographs of water levels.

\section{Driller's Well Logs}

The Ohio Department of Natural Resources Division of Water maintains a database of driller's well logs that were completed at the time of well installation (http://www.dnr. state.oh.us/water/maptechs/wellogs/appNew/Default.aspx). The Ohio Revised Code (ORC) Section 1521.05 (A) requires that these logs be submitted at the completion of every well drilled in the State. The logs contain well-construction data, aquifer characteristics including depth, thickness, and specific capacity (a measure of water-level drawdown in response to withdrawals), and static water levels obtained at the time of drilling. As of 2009, this database contained approximately 781,600 well logs (W. Jones, Ohio Department of Natural Resources, written commun., 2009). The well-log database is extremely valuable to those interested in locating wells by address or latitude and longitude and for obtaining information regarding installation of a new well or aquifer characteristics in nearby areas. The density of these data points in the Tuscarawas River Basin shown in figure 14 reveals the regional wide-spread use of this source of water.

\section{Water-Level Map Generated as Part of this Study}

To evaluate groundwater-flow directions and the existing wells in the basin using drillers' well logs on file with the Ohio Department of Natural Resources, the Ohio Department of Natural Resources Division of Water generated contours of water levels in the basin. The contour lines were drawn by synthesizing water levels from several thousand drillers' well logs for bedrock and sand and gravel aquifers throughout the basin; the logs were created over a 30 -year period (the locations of many of these wells are shown in figure 14 as small gray dots). The process employed to create these contours follows: First, the elevations of the water levels in the well logs were plotted on 1:24,000 scale, 7.5-minute topographic maps. These data were contoured to create the water-level map. The water-level contours were then refined in the consideration of the topographic contours and locations and elevations of the surface-water bodies. The contours were then digitized into a GIS, coded with appropriate contour values, and aligned with contours on adjoining 7.5 minute maps.

As presented in plate 1, the water-level map incorporates water-level data from many different aquifers and from wells of varied construction. Therefore, no inferences can be made concerning water levels in specific aquifers or whether flow occurs between aquifers. Plate 1 is drawn at an approximate scale of 1:195,000 so that the entire basin can be shown on one plate. At this scale, the overall configuration of the waterlevel surface likely has not changed substantially during the past 20 or 30 years; thus, the actual date of water-level measurement was not considered to affect the resulting contours. A relatively large contour interval of $50 \mathrm{ft}$ was used in the original contouring; however, the final map on plate 1 uses contour intervals ranging from 100 to $150 \mathrm{ft}$ to permit plotting of the water-level surface within the entire basin.

Although it is generalized, the water-level map shows several important characteristics of groundwater levels within the basin.

1. Groundwater flow is generally from the upland bedrock areas down into the sand- and gravel-filled valleys. (General flow directions can be inferred by drawing flow lines perpendicular to contours anywhere on the map.)

2. The water-level surface mimics topography and generally follows surface-water flow directions. As noted above, topographic contours were used to refine (but not define) the contouring of the water-level elevations, so this characteristic may be an artifact of the manner in which the contours were drawn in some areas.

3. Several areas (shaded in gray) indicate where data were too sparse to develop a water-level surface. These may be areas in which to focus future data collection.

\section{Water Quality}

Water-quality data are available for streams, reservoirs, lakes, springs, and wells within the Tuscarawas River Basin. The primary public agencies that collect these data are the Ohio Environmental Protection Agency, U.S. Army Corps of Engineers, and the U.S. Geological Survey. The Ohio Environmental Protection Agency and the U.S. Army Corps of Engineers are the only agencies that collect samples within the basin at regular intervals.

\section{Surface Water}

The Ohio Environmental Protection Agency operates a 5-year rotating schedule for collection of biological and water-quality data for streams (fig. 15) and is further described on http://www.epa.state.oh.us/dsw/bioassess/ohstrat.html. Each year, the Ohio Environmental Protection Agency obtains surface-water data from 300 to 400 sampling sites in 10 to 15 watersheds. Aquatic biological, chemical, and physical monitoring and assessment techniques are used in surveys to produce an Invertebrate Community Index (ICI), an Index of Biotic Integrity (IBI), a Qualitative Habitat Evaluation Index (QHEI), and a modified Index of Well-Being (IWB), where applicable. The mainstem of the Tuscarawas River and almost all of its major tributaries have been sampled by the Ohio Environmental Protection Agency at one time or another. In 2007, the Ohio Environmental Protection Agency released a graphical summary of these surveys of water quality (Ohio 


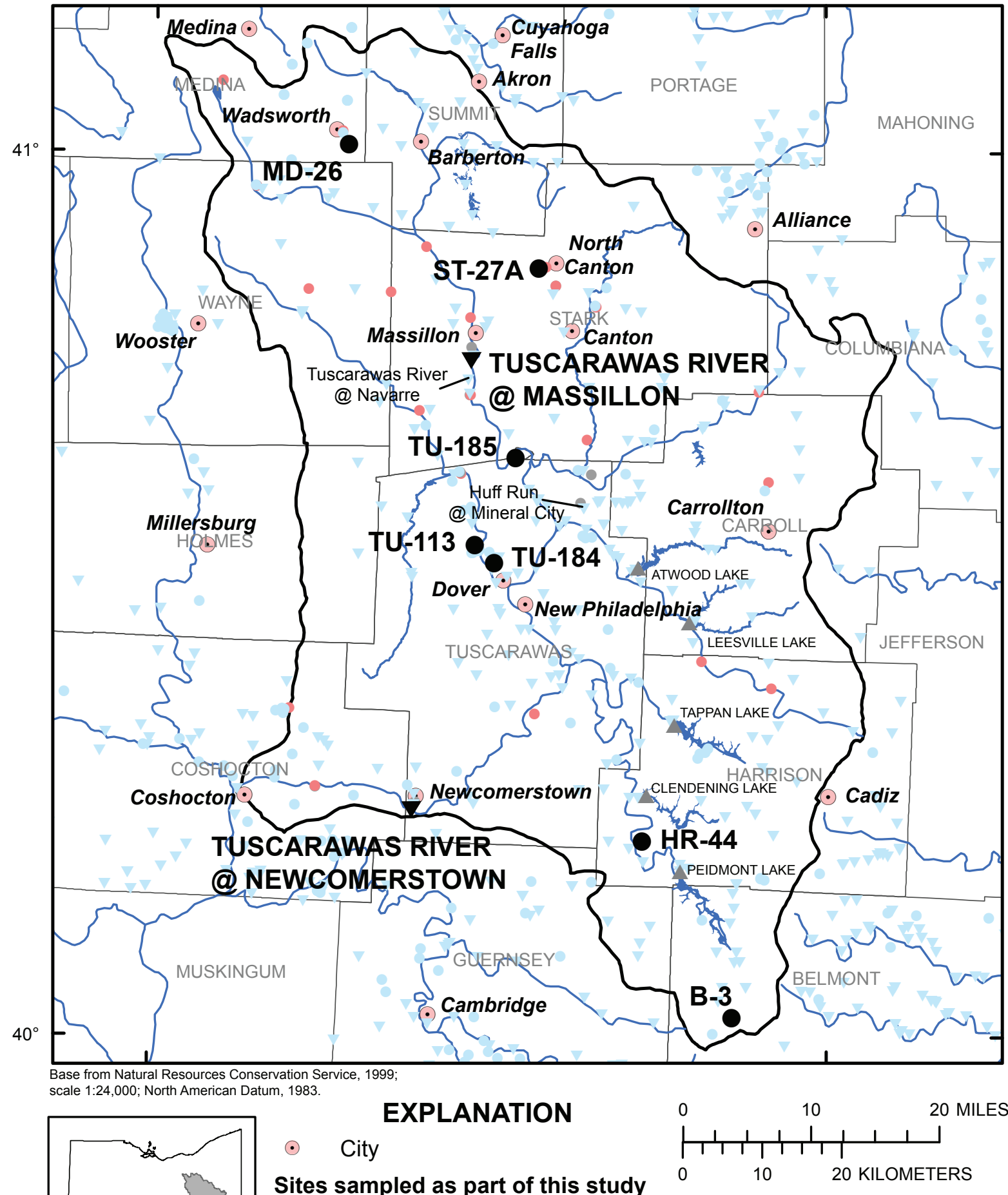

Sites sampled as part of this study with identifier

- Groundwater site

$\nabla$ Surface-water site

U.S. Geological Survey sites

Groundwater site

Surface-water site

U.S. Army Corps of Engineers sites

- Reservoir water-quality monitor

Ohio Environmental Protection

Agency groundwater sites

- Active sampling site

- Inactive sampling site

County boundary

Basin boundary

Surface water

Figure 15. Locations of water-quality data-collection sites in and around the Tuscarawas River Basin, Ohio. (Sites may overlap.) 
Environmental Protection Agency, 2007), which shows that many headwater streams across the basin have low scores and fail their aquatic-life use goal. In 2008, the Ohio Environmental Protection Agency stated that 86 percent of the mainstem of the Tuscarawas River from Chippewa Creek to the mouth in Coshocton was in full attainment, and the remaining 14 percent was in partial attainment, of aquatic life use goals (Ohio Environmental Protection Agency, 2009a).

The U.S. Army Corps of Engineers Huntington (West Virginia) District collects data on basic water-quality indicators for selected lakes and reservoirs (http://www.lrh-wc.usace. army.mil/wq/lkcond.html). As of 2009, water-quality monitors were operating at Atwood, Leesville, Tappan, Clendening, and Piedmont Lakes and measuring temperature, dissolved oxygen, $\mathrm{pH}$, and conductivity on an hourly basis. These data are presented on the Web site.

Two water-quality monitors have been operated by the U.S. Geological Survey (in cooperation with the Ohio Department of Natural Resources) within the Tuscarawas River Basin. From 1968 to 1991, a water-quality monitor was maintained at the Tuscarawas River at Navarre (U.S. Geological Survey site number 03117100); dissolved oxygen, $\mathrm{pH}$, temperature, and specific conductance were monitored on an hourly basis and reported at http://waterdata.usgs.gov/nwis/ nwisman/?site_no=03117100\&agency_cd=USGS. From 1999 to 2006, the U.S. Geological Survey maintained a waterquality monitor at Huff Run at Mineral City (U.S. Geological Survey site number 03121850); temperature and specific conductance were monitored on an hourly basis and reported at http://waterdata.usgs.gov/nwis/uv?03121850. In early 2009, this site was re-established and represents the only operational water-quality monitor on a stream in the basin (fig. 15).

The U.S. Geological Survey and several other organizations, including watershed groups listed in table 6 , periodically collect grab samples at sites in the basin. Among academic institutions, only the National Center for Water Quality Research at Heidelberg College collects water-quality data on a regular basis that are widely distributed and readily available (see http://www.heidelberg.edu/wql). The nearest site is outside the basin on the Muskingum River at McConnelsville, about $60 \mathrm{mi}$ downstream from the confluence of the Tuscarawas and Walhonding Rivers.

\section{Groundwater}

Sites where groundwater-quality information was obtained by the Ohio Environmental Protection Agency as part of their Ambient Ground Water Monitoring Network included 41 production wells in the counties that encompass the Tuscarawas River Basin (Ohio Environmental Protection Agency, 2006a). Nineteen of these sites were active in 2009. Untreated (raw) water was analyzed for major elements, trace elements, nutrients, and about 60 VOCs every 6 or 18 months. Samples from some sites also were analyzed for semi-volatile organic compounds and pesticides. These data are available on the Ohio Environmental Protection Agency's Web site (http://www.epa.state.oh.us/ddagw/pdu/ambient.html).

\section{Sampling Done as Part of this Study}

As part of the current study, water samples from seven wells and two surface-water sites (table 7; fig. 15) were analyzed for a wide variety of constituents and several age-dating compounds to document water quality within representative land-use areas of the basin. The overall goals of the sampling were first to examine the range of concentrations that could be observed in a variety of land use settings where water may or may not be used for water supply, and second to examine the effectiveness of age-dating compounds - compounds that define the elapsed time since water entered the groundwater system - in understanding the age of water in shallow groundwater systems in the basin. With the attainment of these two goals, decisionmakers will have the information needed to evaluate the susceptibility and sustainability of the water resources of the basin in the future.

All water samples were collected during July and August of 2006 using standardized sampling techniques described in U.S. Geological Survey (1997-present) and Francy and others (1998). A detailed quality-assurance/quality-control plan was developed specifically for this sampling effort and includes details on sampling procedures, sample handling, and all water-quality analyses (the plan is available by request from the authors or contact listed in the front of this publication). Each site was sampled once, and one blank sample was collected in the field for quality-assurance purposes. Except for $\mathrm{N}, \mathrm{N}$-diethyl-meta-toluamide (an insecticide used as a mosquito repellent commonly known as DEET), all other constituents analyzed in the blank water sample were below detection limits (this and other DEET detections are further described below). Water-quality data collected as part of this effort are presented in appendix 2 and are summarized in several tables in subsequent sections.

The seven wells were chosen by examining dominant land use(s) within a 1-mi radius of the well and with regard to the primary aquifer(s) tapped by the wells and the hydrologic setting within the basin (table 7). For this study, dominant land uses were defined as those that accounted for more than 30 percent of the total land-use area, as adapted from protocols established by the U.S. Geological Survey National Water Quality Assessment Central Processing Group land-use landcover mapping efforts (http://water.wr.usgs.gov/cpg/). Drillers' well logs provided by the Ohio Department of Natural Resources show that these wells are screened in unconfined, semi-confined, or fully confined aquifers or are open to sandstone bedrock or unconsolidated sands and gravels in both upland (recharge) and lowland (discharge) hydrogeologic settings. The wells ranged in depth from $66 \mathrm{ft}$ to $230 \mathrm{ft}$ below land surface. In wells where water-level measurements could be made, all water levels were within $60 \mathrm{ft}$ of the land surface (table 7; appendix 2). Of the two surface-water sites, one is located near the headwaters (Tuscarawas River at Massillon, 


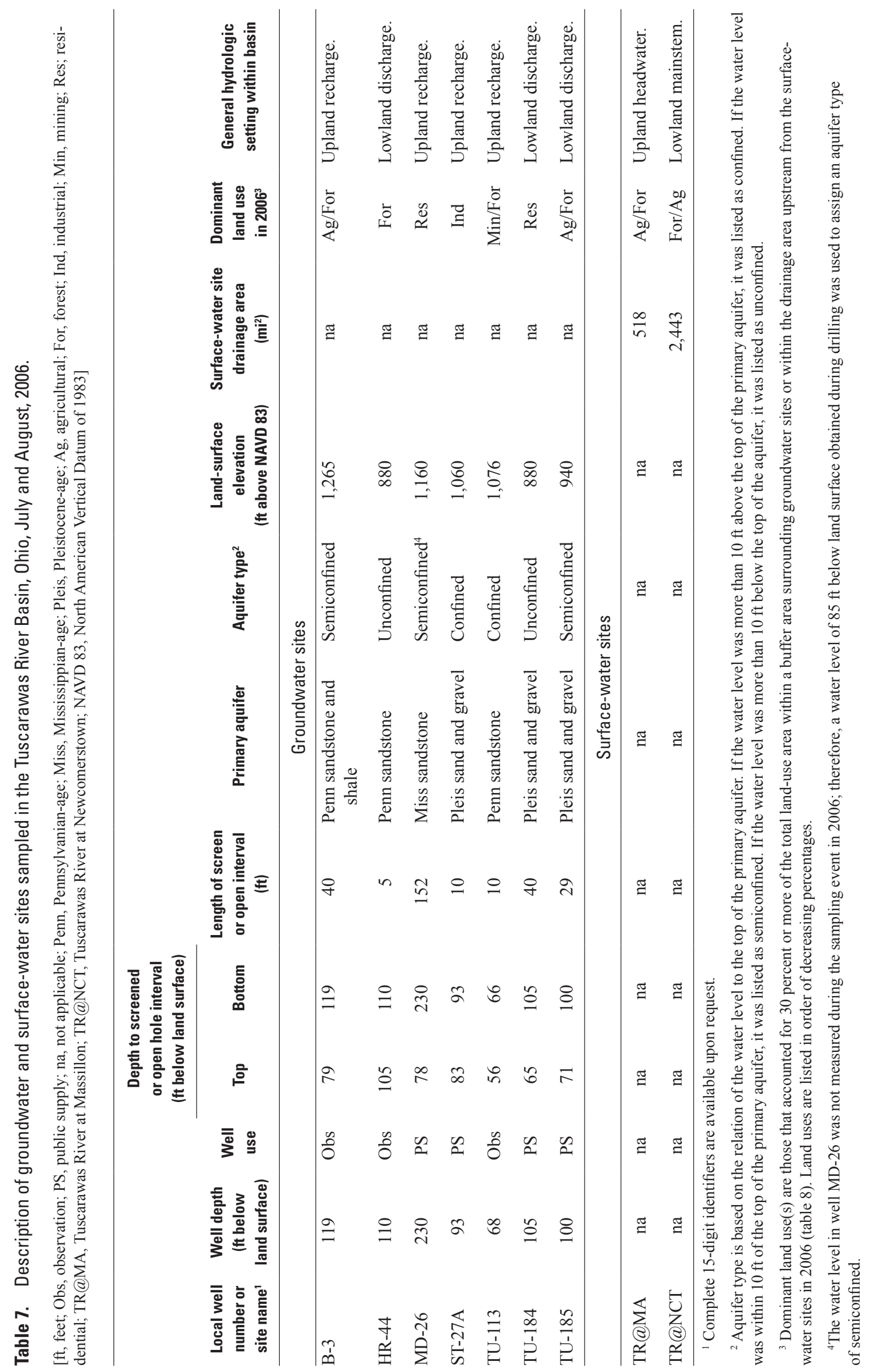


denoted as TR@MA in subsequent tables and figures) and one is close to the mouth of the watershed (Tuscarawas River at Newcomerstown, denoted as TR@NCT).

Land use surrounding sampling sites was determined differently for groundwater sites and surface-water sites. Land use near groundwater sites was defined within a 1-mi circular buffer area surrounding each well and was examined for land uses in 1992 and during water sampling in 2006. Land use in 1992 was calculated for the 1-mile buffer areas using the National Land Cover Dataset (Multi-Resolution Land Characteristics Consortium, 2008). Land use during water sampling in 2006 was characterized by U.S. Geological Survey staff in the field, transcribed to hard-copy aerial photographs, then digitized and coded with land-use definitions. The percentages of each land use within the buffered areas were then calculated on the basis of these digitized polygons. Compilation of data on land use surrounding surface-water sites followed the methods described by Adolphson and others (2002), which include land-use characterization of the entire upstream drainage area. The drainage basin for each surface-water site was delineated using the U.S. Geological Survey product known as Ohio StreamStats (Koltun and others, 2006) that is based on the National Hydrography Dataset and a 10-m digital elevation model.

The results of the land-use calculations for buffer areas surrounding wells and the drainage areas for stream sites are given in tables 8 and 9 . These results indicate that, over the 14-year period between 1992 and 2006, land uses surrounding the wells and within the surface-water site drainage basins were dominated by agricultural and forested land uses. Similar to the overall land-use distributions in the basin, the dominant land uses remain agricultural and forested, but increases in residential and industrial land uses within these areas also were noted.

\section{Field Parameters, Major and Trace Elements, and Nutrients}

During sampling, oxidation-reduction potential, turbidity, dissolved oxygen, $\mathrm{pH}$, specific conductance, air and water temperature, alkalinity (along with bicarbonate and carbonate), acidity, sulfide, ferrous iron $\left(\mathrm{Fe}^{2+}\right)$, and total iron and were measured in the field at all sites (appendix 2). Values of most of these characteristics were similar to those expected in water samples from eastern Ohio and those reported in other waterquality reports cited above. For example, specific conductance, which is a general indicator of dissolved constituents, ranged from 381 to $2,680 \mu \mathrm{S} / \mathrm{cm}$. Several samples had residue on evaporation concentrations (synonymous with total dissolved solids) greater than $500 \mathrm{mg} / \mathrm{L}$, including samples from groundwater sites TU-184, ST-27A, TU-113 and both samples from the Tuscarawas River. The highest specific conductance and residue on evaporation was measured in a groundwater sample from well TU-113, which is located adjacent to a reclaimed coal mine. The water from TU-113 also had the lowest $\mathrm{pH}$ of 5.5. These and many other water-quality characteristics described later in this section are characteristic of acid mine drainage in eastern Ohio. The two surface-water samples and groundwater collected from well ST-27A also had relatively

Table 8. Land use surrounding sampling sites in the Tuscarawas River Basin, Ohio.

[Shaded values highlight land uses that account for 30 percent or greater of the land within a 1-mile radius (for groundwater sites) or upstream drainage areas (surface-water sites); TR@MA, Tuscarawas River at Massillon; TR@NCT, Tuscarawas River at Newcomerstown]

\begin{tabular}{|c|c|c|c|c|c|c|c|c|c|c|}
\hline \multirow{3}{*}{ Site } & \multicolumn{10}{|c|}{ Land use (percent) } \\
\hline & \multicolumn{2}{|c|}{ Agriculture } & \multicolumn{2}{|c|}{ Forest } & \multicolumn{2}{|c|}{ Industrial } & \multicolumn{2}{|c|}{ Mining } & \multicolumn{2}{|c|}{ Residential } \\
\hline & 1992 & 2006 & 1992 & 2006 & 1992 & 2006 & 1992 & 2006 & 1992 & 2006 \\
\hline \multicolumn{11}{|c|}{ Groundwater sites } \\
\hline B-3 & 61.9 & 38.1 & 33.0 & 33.3 & 1.7 & 0.0 & 0.0 & 0.0 & 3.3 & 28.6 \\
\hline HR-44 & 23.6 & 26.3 & 76.3 & 57.9 & .0 & .0 & .0 & .0 & .1 & 15.8 \\
\hline MD-26 & 70.6 & 28.6 & 25.3 & 14.3 & .1 & 14.3 & .0 & .0 & 3.9 & 42.9 \\
\hline ST-27A & 22.6 & .0 & 21.9 & 15.0 & 43.7 & 85.0 & .0 & .0 & 11.7 & .0 \\
\hline TU-113 & 49.8 & .0 & 46.9 & 45.0 & .0 & .0 & 2.3 & 55.0 & .9 & .0 \\
\hline TU-184 & 30.6 & 4.8 & 4.5 & 19.0 & 6.6 & 23.8 & .0 & .0 & 58.3 & 52.4 \\
\hline TU-185 & 45.0 & 45.0 & 28.2 & 30.0 & .2 & .0 & .0 & .0 & 26.6 & 25.0 \\
\hline \multicolumn{11}{|c|}{ Surface-water sites } \\
\hline TR@MA & 55.8 & 40.3 & 34.6 & 37.7 & 2.5 & .6 & .3 & .0 & 6.8 & 21.4 \\
\hline TR@NCT & 52.0 & 38.6 & 42.9 & 46.7 & 1.4 & .3 & .4 & .0 & 3.3 & 14.3 \\
\hline
\end{tabular}


Table 9. Land-use changes between 1992 and 2006 for sampling sites in the Tuscarawas River Basin, Ohio.

[Ag, agricultural; For, forest; Ind, industrial; Min, mining; Res; residential; TR@MA, Tuscarawas River at Massillon; TR@NCT, Tuscarawas River at Newcomerstown]

\begin{tabular}{|c|c|c|c|}
\hline \multirow[b]{2}{*}{ Site } & \multicolumn{2}{|c|}{ Dominant land use $^{1}$} & \multirow{2}{*}{$\begin{array}{l}\text { Land-use changes of more than } \\
10 \text { percent between } 1992 \text { and } 2006\end{array}$} \\
\hline & 1992 & 2006 & \\
\hline \multicolumn{4}{|c|}{ Groundwater sites } \\
\hline B-3 & $\mathrm{Ag} /$ For & $\mathrm{Ag} /$ For & Loss in Ag; gain in Res. \\
\hline HR-44 & For & For & Loss in For; gain in Res. \\
\hline MD-26 & $\mathrm{Ag}$ & Res & Loss in Ag/For; gain in Res/Ind. \\
\hline ST-27A & Ind & Ind & Loss in $\mathrm{Ag} / \mathrm{Res}$; gain in Ind. \\
\hline TU-113 & $\mathrm{Ag} /$ For & Min/For & Loss in Ag; gain in Min. \\
\hline TU-184 & $\mathrm{Res} / \mathrm{Ag}$ & Res & Loss in Ag; gain in Ind/For. \\
\hline TU-185 & $\mathrm{Ag}$ & $\mathrm{Ag} /$ For & No change. \\
\hline \multicolumn{4}{|c|}{ Surface-water sites } \\
\hline TR@MA & $\mathrm{Ag} / \mathrm{For}$ & $\mathrm{Ag} / \mathrm{For}$ & Loss in Ag; gain in Res. \\
\hline TR@NCT & $\mathrm{Ag} /$ For & For/Ag & Loss in Ag; gain in Res. \\
\hline
\end{tabular}

${ }^{1}$ Dominant land use(s) were defined as those that were 30 percent or more of the total land-use area within a buffer area surrounding groundwater sites or within the drainage area upstream from surface-water sites in 2006 (table 8). Land uses are listed in order of decreasing percentages.

elevated specific conductance. Well ST-27A is located in an industrial and residential area west of North Canton.

Major- and trace-element chemistry in groundwater was typical that in of other samples collected in the basin, as reported by Sedam and Francy (1993), and similar to the values in the Ohio Environmental Protection Agency's Ambient Ground Water Network (Ohio Environmental Protection Agency, 2006a). In general, water chemistry was characterized by calcium-bicarbonate type waters as shown on the Piper diagram in figure 16 . The sample from well HR-44 (surrounded by forested land use) had the lowest concentrations of many dissolved constituents and the highest concentration of dissolved oxygen of any of the groundwater samples, although dissolved oxygen concentration was still only $1.4 \mathrm{mg} / \mathrm{L}$. Well TU-113 (adjacent to a reclaimed coal mine) had the highest concentrations of hardness, calcium, magnesium, potassium, sulfate, iron, manganese, nickel, and strontium and is classified as calcium-sulfate-bicarbonate type water (note how this sample plots in a different part of the Piper diagram on figure 16). Well B-3 had the highest concentrations of sodium and the lowest concentrations of hardness, indicating that this water sample had been affected by water softening.

As described previously, the northern reaches of the Tuscarawas River experienced contamination from chloride derived from salt mining near Barberton. Groundwater from well ST-27A (in the northern part of the basin, west of North Canton) had a chloride concentration $175 \mathrm{mg} / \mathrm{L}$, and surfacewater samples analyzed as part of this study had chloride concentrations of $206 \mathrm{mg} / \mathrm{L}$ and $119 \mathrm{mg} / \mathrm{L}$ at the Tuscarawas River at Massillon and Newcomerstown, respectively (appendix 2). These three sites have chloride concentrations one to two orders of magnitude greater than the remaining six groundwater sites. A more detailed analysis of water-quality constituents would be necessary to confirm that salt mining was indeed the source of this elevated chloride concentration.

Concentrations of nutrients (including forms of nitrogen as nitrate, nitrite, and ammonia, and phosphorus as orthophosphate) were less than $2 \mathrm{mg} / \mathrm{L}$ at all sites and were generally greater in surface-water samples than in groundwater samples (except for ammonia). Concentrations of nitrite plus nitrate were greater than $1.0 \mathrm{mg} / \mathrm{L}$ in both surface-water samples. Nutrients are derived from fertilizers and human and animal wastes, and elevated concentrations are typically associated with wastewater or waters near agricultural facilities. Groundwater from well TU-185 (with a 1-mile buffer area dominated by agricultural land use) had the highest nitrate concentration of $1.8 \mathrm{mg} / \mathrm{L}$, whereas well ST-27A (dominated by industrial land use) had the highest ammonia concentration of $0.73 \mathrm{mg} / \mathrm{L}$. Ammonia also can be derived from wastewater discharges that include septic systems and industrial effluents. 


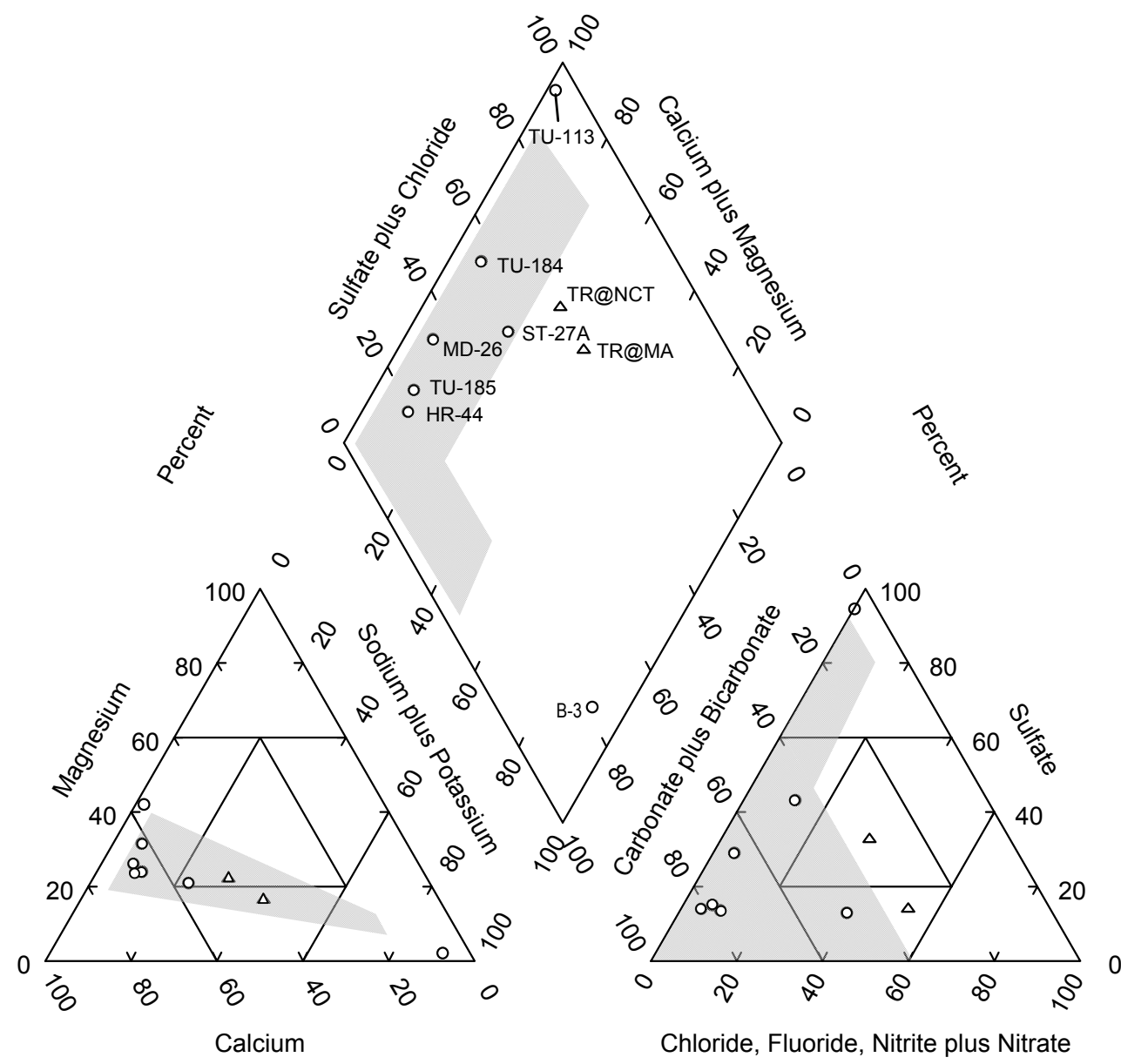

Percent

\section{EXPLANATION}

Approximate distribution of samples reported in Sedam and Francy (1993) and Ohio Environmental Protection Agency (2006a)

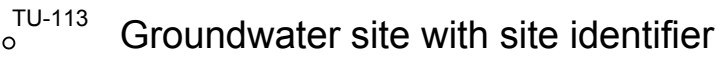

$\Delta^{\text {TR@MA }}$ Surface-water site with site identifier

Figure 16. Piper diagram of water quality in samples collected in the Tuscarawas River Basin, Ohio, 2006. (TR@MA, Tuscarawas River at Massillon; TR@NCT, Tuscarawas River at Newcomerstown) 


\section{Pesticides}

Analysis of 63 pesticides in groundwater and surface water revealed that 13 different pesticides or pesticide degradates were detected in surface-water samples (tables 10 and 11). Groundwater samples did not contain any detectable concentrations of these compounds. As noted by Gilliom and others (2006), this is not an uncommon result because streams are more vulnerable to pesticide contamination than groundwater in most hydrologic settings. Of the 13 pesticides detected, 3, 4-dichloroaniline, acetochlor, atrazine, metolachlor, prometon, simazine, and terbuthylazine were detected at concentrations greater than the reporting levels (reporting levels are described in Childress and others (1999), Bonn (2008), and U.S. Geological Survey (2008b) and are defined in appendix 3). All of these compounds are herbicides designed to deter growth of grasses and other unwanted weeds in corn and soybean fields. Other pesticides, including 2-chloro-4isopropylamino-6-amino-s-triazine (CIAT; a degradate of the herbicide atrazine), carbaryl (an insecticide also known by the trade name Sevin), chlorpyrifos (an insecticide also known by the trade names Dursban and Lorsban), fipronil (an insecticide used in products such as Frontline, Regent, and Termidor), and two fipronil degradates (desulfinyl fipronil and fipronil sulfide) were detected at estimated concentrations at or near the reporting levels.

\section{Bacteria}

Water samples were analyzed for the presence of bacteria to determine whether groundwater and surface water had evidence of contributions from human and animal wastes. Total coliforms include several organisms that are found in the human intestine, soils, vegetation, and industrial wastes (Francy and others, 2000). When present, they indicate a possibility, but not a certainty, that disease-causing organisms also may be present in the water. These data can be used as a rough measure of source-water quality and as a screen for fecal contamination. E. coli is a member of the total coliform group and its presence is direct evidence of fecal contamination from warm-blooded animals. Total coliform (bacteria) were detected or estimated in water from four wells, B-3, HR-44, TU-113, and TU-185, and from both surface-water sites. Well B-3 had an estimated 5 colonies per $100 \mathrm{~mL}$ of $E$. coli, and both of the surface-water sites had concentrations greater than the detection limit ( 1 colony per $100 \mathrm{~mL}$ of water sample), indicating contamination by urban wastewater discharges (described in more detail below).

\section{Volatile Organic Compounds}

VOCs include solvents and other compounds typically associated with urban land uses, septic systems, hazardouswaste disposal sites, and gasoline storage and release sites (Zogorski and others, 2006). Of the 61 compounds analyzed in the current study, three were present at concentrations greater than the minimum reporting level, and one additional VOC was estimated at slightly less than the minimum reporting level, (table 12) in the surface-water sample from the Tuscarawas River at Massillon. The other surface-water sample and none of the groundwater samples contained detectable concentrations of VOCs. The three compounds were cis-1, 2-dichloroethylene (a solvent), trichlorofluoromethane (also known as CFC-11, used as a refrigerant and in spray-can propellants), and trichloromethane (commonly called chloroform, which is produced during the chlorination of drinking and wastewater). Chloroform is one of the most frequently reported VOCs in groundwaters and surface waters in the United States (Ivahnenko and Barbash, 2004; Zogorski and others, 2006). The concentration of another CFC compound (dichlorodifluoromethane, CFC-12) was estimated to be less than the minimum reporting level. Although VOCs have been documented in water adjacent to many urban areas throughout the basin (see, for example Ohio Environmental Protection Agency 1994c, 1998b, 2003, 2006a), no other VOCs were detected in groundwaters or surface waters at or above the minimum reporting levels listed in table 12 .

\section{Wastewater Compounds}

Wastewater compounds include organic compounds typically found in urban wastewater discharges, such as fragrances, solvents, insect repellents, detergents, disinfectants, plasticizers, and flame retardants. Overall, 10 different compounds were detected in five groundwater samples (tables 13 and 14). Surface-water samples did not contain concentrations above the reporting levels of any wastewater compounds. A sample from well B-3 in Belmont County had estimated concentrations of 2-methylnaphthalene, fluoranthene, naphthalene, anthracene, phenanthrene, phenol, pyrene, tris (2-chloroethyl) phosphate, and N,N-diethyl-meta-toluamide (DEET) that were less than their respective reporting levels (tables 13 and 14). Several of these compounds, including 2-methylnaphthalene, fluoranthene, anthracene, phenanthrene, and pyrene, are indicative of creosote, coal tar, or asphalt contamination; however, this same sample did not have concentrations of petroleum hydrocarbons greater than the minimum reporting level. N, N-diethyl-meta-toluamide (DEET) was present in four of the samples but also was present at an estimated concentration of $0.0063 \mu \mathrm{g} / \mathrm{L}$ in a quality-assurance field blank, indicating that contamination of the sample may have occurred during sampling $(0.0063 \mu \mathrm{g} / \mathrm{L}$ is well below the $\mathrm{N}, \mathrm{N}$-diethylmeta-toluamide reporting limit of $0.5 \mu \mathrm{g} / \mathrm{L})$. Wilde and others (2004) and Reich and others (2006) established that even the smallest use of this insect repellent by persons visiting or servicing a well (including sample-collection crews) can cause contamination of water samples. Even though the reported DEET concentrations were more than three times greater than those detected in the blank sample, the analytical results were still at estimated concentrations below the reporting levels. Samples with concentrations at least three times greater than the blank include water from well B-3 and both of the surface- 
water sites. As noted above, samples obtained at these sites likely contained wastewater discharge.

\section{Radionuclides}

Concentrations of uranium, radium, and radon in water samples were determined to evaluate the potential of contamination of water by radionuclides primarily derived from coal. Data on analyses of 365 coal samples, stored in the U.S. Geological Survey COALQUAL database (Bragg and others, 1998) that were obtained from counties that include the Tuscarawas River Basin, include solid-phase uranium concentrations ranging from 0.1 to $35 \mathrm{ppm}$ (parts per million; whole coal basis) with an average of $2.2 \mathrm{ppm}$. Moreover, concentrations of radioactive elements in ash from coal-fired incinerators can be approximately 10 times the concentration in the original coal (Zielinski and Finkelman, 1997). Concentrations of dissolved uranium in water samples obtained during this study were less than $1 \mu \mathrm{g} / \mathrm{L}$ with the greatest concentrations of 0.86 and $0.80 \mu \mathrm{g} / \mathrm{L}( \pm 0.04 \mu \mathrm{g} / \mathrm{L})$ in surfacewater samples. Concentrations in groundwater samples ranged from 0 to $0.42 \mu \mathrm{g} / \mathrm{L}$ (concentrations of $0 \mu \mathrm{g} / \mathrm{L}$ are possible for uranium analyses because the detection method is based on counts of uranium decay (McCurdy and others, 2008)). Radium, a highly radioactive decay product of uranium, was analyzed as a combination of all radium isotopes and reported as alpha-emitting radium isotopes in appendix 2. Analytical results indicated that concentrations in all samples were less than $2 \mathrm{pCi} / \mathrm{L}$, with the greatest concentration in groundwater samples from TU-113 (1.9 pCi/L), ST-27A (0.87 pCi/L), and MD-26 $(0.56 \mathrm{pCi} / \mathrm{L})$. Radon is a naturally occurring radioactive gas produced by the decay of radium. Radon emitted by soil, sediment, and rocks beneath homes is the primary source of radon in indoor air (Harrell and others, 1993). Radon was present in all groundwater samples at concentrations greater than the sample-specific minimum detectable concentrations and ranged from $30 \mathrm{pCi} / \mathrm{L}$ in well TU-113 to $1,930 \mathrm{pCi} / \mathrm{L}$ in well HR-44. (Sample-specific minimum detectable concentrations may be different for each sample because of unexpected chemical and instrumental interferences and small sample sizes (McCurdy and others, 2008).)

\section{Water-Quality Results in Relation to Drinking-Water Standards}

There were no exceedances of U.S. Environmental Protection Agency Primary Drinking Water Standards for groundwater or surface-water samples collected as part of this study; however, Secondary Drinking Water Standards for $\mathrm{pH}$, iron, manganese, sulfate, and total dissolved solids (ROE) were exceeded in several samples (table 15; U.S. Environmental Protection Agency, 2008a). For water purveyors in the Tuscarawas River Basin, the primary water-quality problems from major and trace elements are related to elevated concentrations of iron and manganese (Walker, 1959; Winslow and White, 1966; Ohio Environmental Protection Agency, 2006a; Beck and others, undated $b$; Golden and others, undated a; Hogan and others, undated b; and Zoller and others, undated a). Samples from five of seven groundwater sites had dissolved manganese concentrations greater than the Secondary Maximum Contaminant Levels $(50 \mu \mathrm{g} / \mathrm{L})$, and three of seven had dissolved iron concentrations in excess of the Secondary Maximum Contaminant Levels $(300 \mu \mathrm{g} / \mathrm{L})$.

Currently (2009), no Maximum Contaminant Level has been established for radon in drinking water; however, a proposed Maximum Contaminant Level of $300 \mathrm{pCi} / \mathrm{L}$ for radon is under review (U.S. Environmental Protection Agency, 2009). Water from three wells (HR-44, TU-185, and B-3) contained radon concentrations greater than the proposed Maximum Contaminant Level.

\section{Hydrogen and Oxygen Isotopes}

Water samples were analyzed for the isotopes of hydrogen $\left({ }^{2} \mathrm{H} /{ }^{1} \mathrm{H}\right.$, referred to as $\left.\delta \mathrm{D}\right)$ and oxygen $\left({ }^{18} \mathrm{O} /{ }^{16} \mathrm{O}\right.$ referred to as $\delta^{18} \mathrm{O}$ ) and are reported in per mil (ratios of the isotopes relative to established standards). These ratios are useful in examining the recharge history of groundwater because hydrogen and oxygen are part of the water molecule and generally are not affected by processes that may affect dissolved constituents (Kendall and McDonnell, 1998). Samples collected in the Tuscarawas River basin were plotted with respect to the meteoric water line in figure 17: this line describes the generalized relations among the isotopes in rainwater samples throughout the world, as described by Craig (1961). If samples lie along this line, they are assumed to have originated from rainfall or snow from within the atmosphere and were not affected by other isotope fractionation processes. Comparison of the composition of groundwater and surface-water samples with the meteoric water line provides a unique record of the source (such as groundwater inflow or surface water) and evaporative history of the sample. The seven groundwater samples plot above the meteoric water line, whereas the two surface-water samples lie on or below the line (fig. 17). Samples collected from the Tuscarawas River had $\delta \mathrm{D}$ and $\delta^{18} \mathrm{O}$ values that were relatively enriched (greater) compared to groundwater samples. The greater values in surface water are indicative of summer precipitation and the effects of evaporation, whereas the groundwater samples reflect a mixture of recharge with most water derived during Ohio's long recharge periods that occur during winter and spring. The most depleted sample (MD-26) also had the lowest recharge temperature (described in more detail below) of $8 \mathrm{deg} \mathrm{C}$, consistent with winter precipitation.

\section{Age-Dating Tracers}

To further investigate the characteristics of groundwater recharge, the concentrations of age-dating tracers, including chlorofluorocarbons, sulfur hexafluoride, trifluoromethyl sulfurpentafluoride, and tritium were determined in groundwater samples (appendix 2). Although some of these compounds occur naturally in the atmosphere at extremely small concentrations, human activities have caused their concentrations to increase. Detailed analysis of atmospheric samples has 
Table 10. Pesticides analyzed in groundwater and surface-water samples from the Tuscarawas River Basin, Ohio, 2006.

[All values are in micrograms per liter; $<$, less than; IRL, interim reporting level; LRL, laboratory reporting level]

\begin{tabular}{|c|c|c|c|}
\hline Constituent (USGS parameter code) & $\begin{array}{l}\text { Reporting } \\
\text { level }^{1}\end{array}$ & $\begin{array}{l}\text { Reporting- } \\
\text { level code }\end{array}$ & $\begin{array}{l}\text { Number of } \\
\text { detections }\end{array}$ \\
\hline \multicolumn{4}{|c|}{ Pesticides detected in surface-water samples } \\
\hline $\begin{array}{l}\text { 2-Chloro-4-isopropylamino-6-amino-s-triazine } \\
\text { (CIAT; 04040) }\end{array}$ & $<0.014$ & LRL & 2 \\
\hline 3,4-Dichloroaniline (61625) & $<.0045$ & IRL & 2 \\
\hline Acetochlor (49260) & $<.006$ & LRL & 2 \\
\hline Atrazine (39632) & $<.007$ & LRL & 2 \\
\hline Carbaryl (82680) & $<.041$ & LRL & 1 \\
\hline Chlorpyrifos (38933) & $<.005$ & LRL & 1 \\
\hline Desulfinyl fipronil (62170) & $<.012$ & LRL & 1 \\
\hline Fipronil sulfide (62167) & $<.013$ & LRL & 1 \\
\hline Fipronil (62166) & $<.016$ & LRL & 1 \\
\hline Metolachlor (39415) & $<.006$ & LRL & 2 \\
\hline Prometon (04037) & $<.01$ & LRL & 2 \\
\hline Simazine $(04035)$ & $<.005$ & LRL & 2 \\
\hline Terbuthylazine (04022) & $<.0083$ & LRL & 2 \\
\hline \multicolumn{4}{|c|}{ Pesticides not detected in any water samples } \\
\hline 1-Naphthol (49295) & $<.0882$ & IRL & 0 \\
\hline 2,6-Diethylaniline (82660) & $<.006$ & LRL & 0 \\
\hline 2-Chloro-2,6-diethylacetanilide (61618) & $<.0065$ & LRL & 0 \\
\hline 2-Ethyl-6-methylaniline (61620) & $<.010$ & LRL & 0 \\
\hline 4-Chloro-2-methylphenol (61633) & $<.0050$ & LRL & 0 \\
\hline Alachlor (46342) & $<.005$ & LRL & 0 \\
\hline Azinphos-methyl-oxon (61635) & $<.042$ & LRL & 0 \\
\hline Azinphos-methyl (82686) & $<.050$ & LRL & 0 \\
\hline Benfluralin (82673) & $<.01$ & LRL & 0 \\
\hline Chlorpyrifos, oxon (61636) & $<.0562$ & IRL & 0 \\
\hline cis-Permethrin (82687) & $<.006$ & LRL & 0 \\
\hline Cyfluthrin (61585) & $<.053$ & LRL & 0 \\
\hline Cypermethrin (61586) & $<.046$ & LRL & 0 \\
\hline Dacthal (DCPA; 82682) & $<.003$ & LRL & 0 \\
\hline Diazinon (39572) & $<.005$ & LRL & 0 \\
\hline Dicrotophos (38454) & $<.0843$ & IRL & 0 \\
\hline Dieldrin (39381) & $<.009$ & LRL & 0 \\
\hline Dimethoate (82662) & $<.0061$ & IRL & 0 \\
\hline Ethion monoxon (61644) & $<.021$ & LRL & 0 \\
\hline
\end{tabular}


Table 10. Pesticides analyzed in groundwater and surface-water samples from the Tuscarawas River Basin, Ohio, 2006.-Continued

[All values are in micrograms per liter; $<$, less than; IRL, interim reporting level; LRL, laboratory reporting level]

\begin{tabular}{|c|c|c|c|}
\hline Constituent (USGS parameter code) & $\begin{array}{l}\text { Reporting } \\
\text { level }^{1}\end{array}$ & $\begin{array}{l}\text { Reporting- } \\
\text { level code }^{1}\end{array}$ & $\begin{array}{l}\text { Number of } \\
\text { detections }\end{array}$ \\
\hline \multicolumn{4}{|c|}{ Pesticides not detected in any water samples-Continued } \\
\hline Ethion (82346) & $<.016$ & LRL & 0 \\
\hline Fenamiphos sulfone (61645) & $<.053$ & LRL & 0 \\
\hline Fenamiphos sulfoxide (61646) & $<.040$ & LRL & 0 \\
\hline Fenamiphos (61591) & $<.029$ & LRL & 0 \\
\hline Desulfinylfipronil amide (62169) & $<.029$ & LRL & 0 \\
\hline Fipronil sulfone (62168) & $<.024$ & LRL & 0 \\
\hline Fonofos $(04095)$ & $<.0053$ & LRL & 0 \\
\hline Hexazinone (04025) & $<.026$ & LRL & 0 \\
\hline Iprodione (61593) & $<.026$ & LRL & 0 \\
\hline Isofenphos (61594) & $<.011$ & LRL & 0 \\
\hline Malaoxon (61652) & $<.039$ & LRL & 0 \\
\hline Malathion (39532) & $<.027$ & LRL & 0 \\
\hline Metalaxyl (61596) & $<.0069$ & IRL & 0 \\
\hline Methidathion (61598) & $<.0087$ & LRL & 0 \\
\hline Methyl paraoxon (61664) & $<.019$ & LRL & 0 \\
\hline Methyl parathion (82667) & $<.015$ & LRL & 0 \\
\hline Metribuzin (82630) & $<.028$ & LRL & 0 \\
\hline Myclobutanil (61599) & $<.033$ & LRL & 0 \\
\hline Pendimethalin (82683) & $<.022$ & LRL & 0 \\
\hline Phorate oxon (61666) & $<.027$ & LRL & 0 \\
\hline Phorate (82664) & $<.055$ & LRL & 0 \\
\hline Phosmet oxon (61668) & $<.0511$ & IRL & 0 \\
\hline Phosmet (61601) & $<.0079$ & IRL & 0 \\
\hline Prometryn (04036) & $<.0059$ & LRL & 0 \\
\hline Propyzamide (82676) & $<.004$ & LRL & 0 \\
\hline Tebuthiuron (82670) & $<.016$ & LRL & 0 \\
\hline Terbufos oxon sulfone (61674) & $<.045$ & LRL & 0 \\
\hline Terbufos $(82675)$ & $<.017$ & LRL & 0 \\
\hline Tribufos (61610) & $<.035$ & LRL & 0 \\
\hline Trifluralin (82661) & $<.009$ & LRL & 0 \\
\hline Dichlorvos (38775) & $<.013$ & LRL & 0 \\
\hline
\end{tabular}

${ }^{1}$ Reporting levels and reporting-level codes are described in appendix 3. 
Table 11. Pesticides present in surface-water samples from the Tuscarawas River Basin, Ohio, 2006.

[All concentrations are in micrograms per liter; <, less than; E, estimated concentration; IRL, interim reporting level; LRL, laboratory reporting level]

\begin{tabular}{|c|c|c|c|c|}
\hline $\begin{array}{c}\text { Constituent } \\
\text { (USGS parameter code) }\end{array}$ & $\begin{array}{l}\text { Reporting } \\
\text { level }^{1}\end{array}$ & $\begin{array}{l}\text { Reporting- } \\
\text { level code }\end{array}$ & $\begin{array}{l}\text { Tuscarawas River } \\
\text { at Massillon }\end{array}$ & $\begin{array}{l}\text { Tuscarawas River } \\
\text { at Newcomerstown }\end{array}$ \\
\hline $\begin{array}{l}\text { 2-Chloro-4-isopropylamino-6-amino-s-triazine } \\
\text { (CIAT; 04040) }\end{array}$ & $<0.014$ & LRL & E 0.013 & Е 0.013 \\
\hline 3,4-Dichloroaniline (61625) & $<.0045$ & IRL & E .0018 & E .015 \\
\hline Acetochlor (49260) & $<.006$ & LRL & .010 & .007 \\
\hline Atrazine (39632) & $<.007$ & LRL & .043 & .053 \\
\hline Carbaryl (82680) & $<.041$ & LRL & E .0067 & $<.0410$ \\
\hline Chlorpyrifos (38933) & $<.005$ & LRL & E .0051 & $<.0050$ \\
\hline Desulfinyl fipronil (62170) & $<.012$ & LRL & E .0120 & $<.0120$ \\
\hline Fipronil sulfide (62167) & $<.013$ & LRL & E .0065 & $<.0130$ \\
\hline Fipronil (62166) & $<.016$ & LRL & E .0084 & $<.0160$ \\
\hline Metolachlor (39415) & $<.006$ & LRL & .01 & .122 \\
\hline Prometon (04037) & $<.01$ & LRL & .03 & .03 \\
\hline Simazine (04035) & $<.005$ & LRL & .023 & .019 \\
\hline Terbuthylazine (04022) & $<.0083$ & LRL & .021 & E .0066 \\
\hline
\end{tabular}

${ }^{1}$ Reporting levels and reporting-level codes are described in appendix 3.

provided a well-established record of concentrations in the atmosphere. Age-dating groundwater is a process whereby the time since water entered the groundwater system is quantified. Ages are based on interpretations of concentrations of agedating compounds in groundwater; therefore, ages presented in this report are regarded as "apparent ages." Apparent age refers to the duration (number of years) since isolation from the atmosphere, whereas recharge date is the date (year) of recharge estimated by subtracting the apparent age of the sample from the sample-collection date (for this study, the sample-collection date was 2006.5). For the interpreted ages, it is assumed that the concentration of the tracer was not altered by transport processes from the point of entry to the measurement point in the aquifer. Supporting data accompany the analyses for the age-dating tracers (appendix 2); however, only a summary of the results is presented here.

Recharge temperatures were determined for individual samples using concentrations of dissolved argon and nitrogen gas. Since the amount of gas that can dissolve in water is proportional to the water temperature at the time of recharge, recharge temperatures can be calculated to an accuracy of about 0.5 deg C (Heaton, 1981; Heaton and Vogel, 1981; Heaton and others, 1983; Busenberg and others, 1993; Stute and Schlosser, 1999). All recharge temperatures were corrected for "excess air" (atmospheric gases trapped in the unsaturated zone that interact with groundwater and may affect gas concentrations). Additionally, in oxygen-poor groundwaters, denitrification can produce excess nitrogen gas in water samples, providing unrealistically higher recharge temperatures than would be expected by equilibrium with the atmosphere and excess air alone. Recharge temperatures for samples collected at ST-27A and TU-184 were corrected by subtracting 2.0 and $0.5 \mathrm{mg} / \mathrm{L}$ nitrogen, respectively, to account for denitrification. After corrections were applied as described above, the seven groundwater samples from the Tuscarawas River Basin collected and analyzed as part of this study yielded recharge temperatures ranging from 8.0 to $13.5 \mathrm{deg} \mathrm{C}$, which compare well with the average annual atmospheric temperature of $10.1 \mathrm{deg} \mathrm{C}$ measured at 18 stations within the basin for the period 1970 to 2000 (National Oceanic and Atmospheric Administration, 2002).

Chlorofluorocarbons (CFCs, including CFC-11, CFC-12, and CFC-113) were analyzed at the U.S. Geological Survey Chlorofluorocarbon Laboratory (Reston, Va.) using purge and trap chromatography with an electron capture detector with a minimum detection limit of approximately 1 picogram/L (http://water.usgs.gov.lab). This detection limit is several orders of magnitude less than the mass-spectrometry detection limit for CFCs analyzed as part of the VOC schedule of the U.S. Geological Survey National Water Quality Laboratory given in table 12. With the lower detection limit, the three different CFCs were detected in all groundwater samples except 
for two samples collected at ST-27A and TU-113 that did not contain detectable concentrations of CFC-113 (appendix 2). Two other samples (HR-44 and TU-184) were determined to be contaminated with CFCs from land-surface sources because $\mathrm{CFC}$ concentrations in the water samples were greater than concentrations that have ever been measured in equilibrium with the atmosphere. CFC contamination may originate from leaking septic tanks, sewer lines, sewage-treatment plants, underground storage tanks, and industrial wastes. In contrast, in anoxic (oxygen-poor) environments, CFCs may degrade due to consumption by anaerobic bacteria. Cook and Solomon (1995) documented that apparent ages derived from CFCs may be greater than they appear where depths to the water table are greater than about $30 \mathrm{ft}$. The time lag is caused by the time it takes for precipitation that falls on the surface to reach the water table. For groundwater samples collected in this study, depths to water were less than $30 \mathrm{ft}$ in wells HR-44, ST-27A, and TU-184 but were greater than $30 \mathrm{ft}$ in wells B-3, TU-113, and TU-185 (depth to water was not available for well MD-26). CFC recharge dates for the groundwater samples range from about 1950 through 1978, with the most consistent dates (those with dates that had less than about 5 years of variation between the three CFC compounds) provided by water from wells ST-27A, TU-113, and TU-185. No apparent relations were noted between depth to water and recharge dates.

Sulfur hexafluoride $\left(\mathrm{SF}_{6}\right)$, a compound used in electrical switches, provides age dates for water that has been recharged since about 1970 (Busenberg and Plummer, 2008). SF ${ }_{6}$ can have a natural source from fluid inclusions in crystalline rocks (Busenberg and Plummer, 2000); however, crystalline rocks are at great depth in the Tuscarawas River Basin. An advantage of using $\mathrm{SF}_{6}$ concentrations as an age-dating tracer is that $\mathrm{SF}_{6}$ does not degrade, which is especially important in anoxic waters that may undergo methanogenesis where CFCs would likely degrade. For the samples collected as part of this study, $\mathrm{SF}_{6}$ was detected in all but one sample (TU-113), and $\mathrm{SF}_{6}$ concentrations provided recharge dates ranging from 1978 to 1996. In addition to analysis of $\mathrm{SF}_{6}$, an experimental tracer, trifluoromethyl sulfurpentafluoride $\left(\mathrm{SF}_{5} \mathrm{CF}_{3}\right)$, was evaluated to determine its usefulness as an age-dating tracer in this hydrologic setting. Details regarding this compound and comparison to other tracers used in this study can be found in Busenberg and Plummer (2008), who note that the origin of $\mathrm{SF}_{5} \mathrm{CF}_{3}$ is uncertain, but may be produced by reaction of $\mathrm{SF}_{6}$ in the atmosphere. For the groundwater samples collected in this study, $\mathrm{SF}_{5} \mathrm{CF}_{3}$ recharge dates range from prior to 1966 through 1995.

Tritium $\left({ }^{3} \mathrm{H}\right)$, an isotope of hydrogen, is naturally produced in the atmosphere; however, testing of thermonuclear bombs in the 1950s and 1960s increased concentrations of tritium above natural background concentrations. Tritium undergoes radioactive decay to produce helium-3 $\left({ }^{3} \mathrm{He}\right)$, and the ratio between tritium and helium-3 produced from tritium decay can be used to accurately date the apparent age of groundwater. Analysis is complicated by helium derived from natural sources, known as terrigenic helium. Possible sources of terrigenic helium in the Tuscarawas River Basin include radioactive decay of thorium or uranium found in glacial tills, coal, and underclay, and escape of natural gas from gas fields that are found in natural reservoirs and subsurface gas storage facilities deep beneath the aquifers in the basin. All of the groundwater samples contained terrigenic helium, with compositions ranging from 17 to 83 percent. The concentrations of tritiogenic helium $\left({ }^{3} \mathrm{He}\right)$ were determined from the measured total dissolved helium concentration and the measured ${ }^{3} \mathrm{He} /{ }^{4} \mathrm{He}$ ratio of dissolved helium with correction for terrigenic helium using the ${ }^{3} \mathrm{He} /{ }^{4} \mathrm{He}$ ratio of terrigenic helium of $2 \times 10^{-8}$ (Schlosser and others, 1988, 1989). The ${ }^{3} \mathrm{He} /{ }^{4} \mathrm{He}$ apparent recharge dates corrected for terrigenic helium range from about 1978 to 1994 .

Comparison of apparent ages among the tracers analyzed in this study is not necessarily a valid exercise because each tracer provides information that may be influenced by different natural or anthropogenic factors and mixing of different age waters often provides misleading results. Because each of the dating techniques has advantages and limitations, data from multiple age-dating tracers were collected to increase the confidence in apparent age (Plummer and others, 2001; Lindsey and others, 2003). In addition, relations between multiple tracers may reveal hydrologic and chemical processes occurring within aquifers. Comparison of $\mathrm{CFC}$ ages with those derived from $\mathrm{SF}_{6}$ and tritium/helium reveals that the CFC dates are consistently older, implying that some anaerobic degradation may have occurred. Except for the water sample obtained from well HR-44, all groundwater samples contained dissolved oxygen concentrations less than $1.0 \mathrm{mg} / \mathrm{L}$ and small quantities of dissolved methane; therefore, CFCs may have been degraded leading to an old bias in apparent age as described by Plummer and Busenberg (1999).

Another factor that complicates interpretation of recharge ages is mixing of water of different ages through long screens or open intervals. Well screens or open intervals that are longer than 10 feet have the potential to combine waters that originate from different flow paths. For example, age-dating tracer data combined with other water-quality data from well B-3, which has a 40-ft screened interval, results in old CFC age dates (ranging from 1962 to 1970.5 ), younger $\mathrm{SF}_{6}$ (1996.5) and tritium/helium (1993.7) dates, and elevated concentrations of a variety of bacterial and wastewater compounds, indicating that mixing of waters of different ages has likely occurred. Screened or open intervals listed in table 7 range from 5 to $152 \mathrm{ft}$. Wells with short screened intervals (10 ft or less) include HR-44 (5 ft), ST-27A (10 ft) and TU-113 $(10 \mathrm{ft})$; wells with longer screened intervals (greater than $10 \mathrm{ft}$ ) include B-3 (40 ft), MD-26 (152 ft), TU-184 (40 ft), and TU-185 (29 ft). More information on age and mixing can be gained by examining data from multiple environmental tracers through plotting sample concentrations relative to known input (atmospheric) concentrations as described by Plummer and others $(2001,2003)$ and Böhlke (2006); however, this topic was beyond the scope of this report. 
Table 12. Volatile organic compounds analyzed in groundwater and surface-water samples from the Tuscarawas River Basin, Ohio, 2006.

[All values are in micrograms per liter; all reporting levels are at the minimum reporting level (MRL)'; TR@MA, Tuscarawas River at Massillon]

\begin{tabular}{|c|c|c|}
\hline Constituent (USGS parameter code) & Reporting level ${ }^{1}$ & $\begin{array}{c}\text { Concentration at } \\
\text { Tuscarawas River } \\
\text { at Massillon }\end{array}$ \\
\hline \multicolumn{3}{|c|}{ Volatile organic compounds detected in water sample at TR@MA } \\
\hline cis-1,2-Dichloroethylene (77093) & $<0.1$ & 0.148 \\
\hline Dichlorodifluoromethane (CFC-12; 34668) & $<.2$ & E.16 \\
\hline Trichlorofluoromethane (CFC-11; 34488) & $<.2$ & 1.1 \\
\hline Trichloromethane (chloroform; 32106) & $<.1$ & .223 \\
\hline \multicolumn{3}{|c|}{ Volatile organic compounds not detected in any water samples } \\
\hline Xylene (81551) & $<.2$ & $<.2$ \\
\hline 1,1,1,2-Tetrachloroethane (77562) & $<.2$ & $<.2$ \\
\hline 1,1,1-Trichloroethane (34506) & $<.1$ & $<.1$ \\
\hline 1,1,2,2-Tetrachloroethane (34516) & $<.2$ & $<.2$ \\
\hline 1,1,2-Trichlorotrifluoroethane (CFC-113; 77652) & $<.1$ & $<.1$ \\
\hline 1,1,2-Trichloroethane (34511) & $<.2$ & $<.2$ \\
\hline 1,1-Dichloroethane (34496) & $<.1$ & $<.1$ \\
\hline 1,1-Dichloroethylene (34501) & $<.1$ & $<.1$ \\
\hline 1,1-Dichloropropene (77168) & $<.2$ & $<.2$ \\
\hline 1,2,3-Trichlorobenzene (77613) & $<.2$ & $<.2$ \\
\hline 1,2,3-Trichloropropane (77443) & $<.2$ & $<.2$ \\
\hline 1,2,4-Trichlorobenzene $(34551)$ & $<.2$ & $<.2$ \\
\hline 1,2,4-Trimethylbenzene (77222) & $<.2$ & $<.2$ \\
\hline 1,2-Dibromo-3-chloropropane (82625) & $<.5$ & $<.5$ \\
\hline 1,2-Dibromoethane (77651) & $<.2$ & $<.2$ \\
\hline 1,2-Dichlorobenzene (34536) & $<.1$ & $<.1$ \\
\hline 1,2-Dichloroethane (32103) & $<.2$ & $<.2$ \\
\hline 1,2-Dichloropropane (34541) & $<.1$ & $<.1$ \\
\hline 1,3,5-Trimethylbenzene (77226) & $<.2$ & $<.2$ \\
\hline 1,3-Dichlorobenzene (34566) & $<.1$ & $<.1$ \\
\hline 1,3-Dichloropropane (77173) & $<.2$ & $<.2$ \\
\hline 1,4-Dichlorobenzene (34571) & $<.1$ & $<.1$ \\
\hline 2,2-Dichloropropane (77170) & $<.2$ & $<.2$ \\
\hline 2-Chlorotoluene (77275) & $<.2$ & $<.2$ \\
\hline 4-Chlorotoluene (77277) & $<.2$ & $<.2$ \\
\hline 4-Isopropylmethylbenzene (77356) & $<.2$ & $<.2$ \\
\hline Acrylonitrile (34215) & $<2.5$ & $<2.5$ \\
\hline
\end{tabular}


Table 12. Volatile organic compounds analyzed in groundwater and surface-water samples from the Tuscarawas River Basin, Ohio, 2006.-Continued

[All values are in micrograms per liter; all reporting levels are at the minimum reporting level (MRL)'; TR@MA, Tuscarawas River at Massillon]

\begin{tabular}{|c|c|c|}
\hline Constituent (USGS parameter code) & Reporting level' & $\begin{array}{c}\text { Concentration at } \\
\text { Tuscarawas River } \\
\text { at Massillon }\end{array}$ \\
\hline \multicolumn{3}{|c|}{ Volatile organic compounds not detected in any water samples-Continued } \\
\hline Benzene (34030) & $<.1$ & $<.1$ \\
\hline Bromobenzene (81555) & $<.2$ & $<.2$ \\
\hline Bromochloromethane (77297) & $<.2$ & $<.2$ \\
\hline Bromodichloromethane (32101) & $<.1$ & $<.1$ \\
\hline Bromomethane (34413) & $<.3$ & $<.3$ \\
\hline Chlorobenzene (34301) & $<.1$ & $<.1$ \\
\hline Chloroethane (34311) & $<.2$ & $<.2$ \\
\hline Chloromethane (34418) & $<.2$ & $<.2$ \\
\hline cis-1,3-Dichloropropene (34704) & $<.2$ & $<.2$ \\
\hline Dibromochloromethane (32105) & $<.2$ & $<.2$ \\
\hline Dibromomethane (30217) & $<.2$ & $<.2$ \\
\hline Dichloromethane (34423) & $<.2$ & $<.2$ \\
\hline Ethylbenzene (34371) & $<.1$ & $<.1$ \\
\hline Hexachlorobutadiene (39702) & $<.2$ & $<.2$ \\
\hline Isopropylbenzene (77223) & $<.2$ & $<.2$ \\
\hline Naphthalene (34696) & $<.5$ & $<.5$ \\
\hline n-Butylbenzene (77342) & $<.2$ & $<.2$ \\
\hline n-Propylbenzene (77224) & $<.2$ & $<.2$ \\
\hline sec-Butylbenzene (77350) & $<.2$ & $<.2$ \\
\hline Styrene (77128) & $<.1$ & $<.1$ \\
\hline Methyl t-butyl ether (MTBE; 78032) & $<.2$ & $<.2$ \\
\hline tert-Butylbenzene (77353) & $<.2$ & $<.2$ \\
\hline Tetrachloroethylene (34475) & $<.1$ & $<.1$ \\
\hline Tetrachloromethane (32102) & $<.2$ & $<.2$ \\
\hline Toluene (34010) & $<.1$ & $<.1$ \\
\hline trans-1,2-Dichloroethene (34546) & $<.1$ & $<.1$ \\
\hline trans-1,3-Dichloropropene (34699) & $<.2$ & $<.2$ \\
\hline Tribromomethane (bromoform; 32104) & $<.2$ & $<.2$ \\
\hline Trichloroethene (39180) & $<.1$ & $<.1$ \\
\hline Vinyl chloride (39175) & $<.2$ & $<.2$ \\
\hline
\end{tabular}

\footnotetext{
${ }^{1}$ Reporting levels are described in appendix 3.
} 
Table 13. Wastewater compounds analyzed in groundwater and surface-water samples from the Tuscarawas River Basin, Ohio, 2006.

[All values are in micrograms per liter; all reporting levels are interim reporting levels (IRLs) ${ }^{1} ;<$, less than]

\begin{tabular}{lcc}
\hline \multicolumn{1}{c}{ Constituent (USGS parameter code) } & Reporting level ${ }^{1}$ & Number of detections $^{c}$ Wastewater compounds detected in water samples listed in table 14 \\
\hline \multicolumn{1}{c}{ 2-Methylnaphthalene (62056) } & $<0.5$ & 1 \\
Anthracene (34221) & $<.5$ & 1 \\
N,N-diethyl-meta-toluamide (DEET; 62082) & $<.5$ & 4 \\
Fluoranthene (34377) & $<.5$ & 1 \\
Naphthalene (34443) & $<.5$ & 1 \\
Phenanthrene (34462) & $<.5$ & 1 \\
Phenol (34466) & $<.5$ & 2 \\
Pyrene (34470) & $<.5$ & 1 \\
Tris (2-butoxyethyl) phosphate (62093) & $<.5$ & 1 \\
Tris (2-chloroethyl) phosphate (62087) & $<.5$ & 1 \\
\hline
\end{tabular}

Wastewater compounds not detected in any water samples

\begin{tabular}{|c|c|c|}
\hline 1,4-Dichlorobenzene (34572) & $<.5$ & 0 \\
\hline 1-Methylnaphthalene (62054) & $<.5$ & 0 \\
\hline 2,6-Dimethylnaphthalene (62055) & $<.5$ & 0 \\
\hline 3-beta-Coprostanol (62057) & $<2$ & 0 \\
\hline 3-Methyl-1(H)-indole (skatole; 62058) & $<1$ & 0 \\
\hline 3-tert-Butyl-4-hydroxy anisole (BHA; 62059) & $<5$ & 0 \\
\hline 4-Cumylphenol (62060) & $<1$ & 0 \\
\hline 4-Octylphenol (62061) & $<1$ & 0 \\
\hline 4-Nonylphenol (62085) & $<5$ & 0 \\
\hline 4-tert-Octylphenol (62062) & $<1$ & 0 \\
\hline 5-Methyl-1H-benzotriazole (62063) & $<2$ & 0 \\
\hline 9, 10-Anthraquinone (62066) & $<.5$ & 0 \\
\hline Acetophenone (62064) & $<.5$ & 0 \\
\hline Acetyl hexamethyl tetrahydronaphthalene (AHTN; 62065) & $<.5$ & 0 \\
\hline Benzo[a]-pyrene (34248) & $<.5$ & 0 \\
\hline Benzophenone (62067) & $<.5$ & 0 \\
\hline beta-Sitosterol (62068) & $<2$ & 0 \\
\hline beta-Stigmastanol (62086) & $<2$ & 0 \\
\hline Bromacil (04029) & $<.5$ & 0 \\
\hline Caffeine (50305) & $<.5$ & 0 \\
\hline Camphor (62070) & $<.5$ & 0 \\
\hline
\end{tabular}


Table 13. Wastewater compounds analyzed in groundwater and surface-water samples from the Tuscarawas River Basin, Ohio, 2006.-Continued

[All values are in micrograms per liter; all reporting levels are interim reporting levels (IRLs) ${ }^{1} ;<$, less than]

\begin{tabular}{|c|c|c|}
\hline Constituent (USGS parameter code) & Reporting level ${ }^{1}$ & Number of detections \\
\hline \multicolumn{3}{|c|}{ Wastewater compounds not detected in any water samples-Continued } \\
\hline Carbazole $(62071)$ & $<.5$ & 0 \\
\hline Cholesterol (62072) & $<2$ & 0 \\
\hline Cotinine $(62005)$ & $<1$ & 0 \\
\hline Diethoxynonylphenol (62083) & $<5$ & 0 \\
\hline Ethoxyoctylphenol (61706) & $<1$ & 0 \\
\hline Hexahydrohexamethylcyclopentabenzopyran (HHCB; 62075) & $<.5$ & 0 \\
\hline Indole (62076) & $<.5$ & 0 \\
\hline Isoborneol (62077) & $<.5$ & 0 \\
\hline Isophorone (34409) & $<.5$ & 0 \\
\hline Isopropylbenzene (62078) & $<.5$ & 0 \\
\hline Isoquinoline (62079) & $<.5$ & 0 \\
\hline Menthol (62080) & $<.5$ & 0 \\
\hline Metalaxyl (50359) & $<.5$ & 0 \\
\hline Methyl salicylate (62081) & $<.5$ & 0 \\
\hline p-Cresol (62084) & $<1$ & 0 \\
\hline Tetrachloroethene (34476) & $<.5$ & 0 \\
\hline Tribromomethane (Bromoform; 34288) & $<.5$ & 0 \\
\hline Tributyl phosphate (62089) & $<.5$ & 0 \\
\hline Triclosan (62090) & $<1$ & 0 \\
\hline Triethyl citrate (62091) & $<.5$ & 0 \\
\hline Triphenyl phosphate (62092) & $<.5$ & 0 \\
\hline Tris (dichloroisopropyl) phosphate (62088) & $<.5$ & 0 \\
\hline
\end{tabular}

${ }^{1}$ Reporting levels are described in appendix 3 .

In general, the detection of tritium, chlorofluorocarbons, and sulfur hexafluoride (if not of terrigenic origin), indicates the presence of waters recharged after 1950 and (or) mixtures of old waters containing fractions of post-1950s water. The complex age-dating tracer chemistry combined with the characteristics of the hydrologic system indicate that sulfur hexafluoride and tritium/helium offer the best opportunities for use of age-dating tracers in this setting. The potential degradation of CFCs in anoxic groundwater may have caused misleading (older) recharge dates and may exclude the use of this tracer in future investigations.
The ultimate value of age-dating tracers is that they provide an indication of the age of the water obtained from a well. Wells that produce 10 - to 20 -yr-old water may show the effects of recent land uses or recent land-use changes. Alternatively, wells that produce 40- to 50-yr-old water may not show the effects of recent land-use change yet, but likely will in the coming decades. Moreover, wells that produce water that is older than 50 yrs may not show appreciable changes throughout a long period of land-use change. 
Table 14. Wastewater compounds detected in groundwater and surface-water samples from the Tuscarawas River Basin, Ohio, 2006.

[All values are in micrograms per liter; all reporting levels are interim reporting levels (IRLs) ${ }^{1}$; $<$, less than; E, estimated]

\begin{tabular}{|c|c|c|c|c|c|c|}
\hline \multirow[b]{2}{*}{ Constituent (USGS parameter code) } & \multirow[b]{2}{*}{$\begin{array}{l}\text { Reporting } \\
\text { level }^{1}\end{array}$} & \multicolumn{3}{|c|}{ Groundwater samples } & \multicolumn{2}{|c|}{ Surface-water samples } \\
\hline & & B-3 & HR-44 & TU-113 & $\begin{array}{l}\text { Tuscarawas River } \\
\text { at Massillon }\end{array}$ & $\begin{array}{c}\text { Tuscarawas River } \\
\text { at Newcomerstown }\end{array}$ \\
\hline 2-Methylnaphthalene (62056) & $<0.5$ & E 0.008 & $<0.5$ & $<0.5$ & $<0.5$ & $<0.5$ \\
\hline Anthracene (34221) & $<.5$ & E .011 & $<.5$ & $<.5$ & $<.5$ & $<.5$ \\
\hline N,N-diethylmetatoluamide (DEET; 62082) & $<.5$ & E .020 & $<.5$ & E .005 & E .099 & E .048 \\
\hline Fluoranthene (34377) & $<.5$ & E .008 & $<.5$ & $<.5$ & $<.5$ & $<.5$ \\
\hline Naphthalene (34443) & $<.5$ & E .070 & $<.5$ & $<.5$ & $<.5$ & $<.5$ \\
\hline Phenanthrene (34462) & $<.5$ & E .036 & $<.5$ & $<.5$ & $<.5$ & $<.5$ \\
\hline Phenol (34466) & $<.5$ & E .261 & $<.5$ & E .387 & $<.5$ & $<.5$ \\
\hline Pyrene (34470) & $<.5$ & E .012 & $<.5$ & $<.5$ & $<.5$ & $<.5$ \\
\hline Tris (2-butoxyethyl) phosphate (62093) & $<.5$ & $<.5$ & E 3.55 & $<.5$ & $<.5$ & $<.5$ \\
\hline Tris (2-chloroethyl) phosphate (62087) & $<.5$ & E .031 & $<.5$ & $<.5$ & $<.5$ & $<.5$ \\
\hline
\end{tabular}

${ }^{1}$ Reporting levels are described in appendix 3.

Table 15. Exceedances of Secondary Maximum Contaminant Levels (SMCLs) in groundwater and surface-water samples from the Tuscarawas River Basin, Ohio, 2006.

[Bold numbers indicate SMCL exceedance (U.S. Environmental Protection Agency, 2008a); <, less than; $>$, greater than; $\mathrm{mg} / \mathrm{L}$, milligrams per liter; $\mathrm{mg} / \mathrm{L}$, micrograms per liter; five-digit numbers in parentheses are USGS parameter codes]

\begin{tabular}{|c|c|c|c|c|c|}
\hline & $\begin{array}{c}\mathrm{pH} \\
(00400)\end{array}$ & $\begin{array}{c}\text { Residue on } \\
\text { evaporation, } \mathrm{mg} / \mathrm{L} \\
(70300)\end{array}$ & $\begin{array}{l}\text { Iron, dissolved, } \\
\mathrm{mg} / \mathrm{L} \\
(01046)\end{array}$ & $\begin{array}{c}\text { Sulfate, dissolved, } \\
\mathrm{mg} / \mathrm{L} \\
(00945)\end{array}$ & $\begin{array}{c}\text { Manganese, } \\
\text { dissolved, mg/L } \\
\text { (01056) }\end{array}$ \\
\hline Site & $\begin{array}{c}\text { SMCL } \\
<6.5 \text { or }>8.5\end{array}$ & $\begin{array}{c}\text { SMCL } \\
>500 \mathrm{mg} / \mathrm{L}\end{array}$ & $\begin{array}{c}\text { SMCL } \\
>300 \mathrm{mg} / \mathrm{L}\end{array}$ & $\begin{array}{c}\text { SMCL } \\
>250 \mathrm{mg} / \mathrm{L}\end{array}$ & $\begin{array}{c}\text { SMCL } \\
>50 \mathrm{mg} / \mathrm{L}\end{array}$ \\
\hline \multicolumn{6}{|c|}{ Groundwater samples } \\
\hline B-3 & 8.4 & 422 & 8 & 55.9 & 4.1 \\
\hline HR-44 & 7.1 & 240 & $<6$ & 29.6 & $<.6$ \\
\hline MD-26 & 6.5 & 265 & 11,100 & 76.4 & 1,420 \\
\hline ST-27A & 7.1 & 691 & 3,310 & 78.7 & 150 \\
\hline TU-113 & 5.5 & 2,740 & 173,000 & 1,690 & 9,060 \\
\hline TU-184 & 7.5 & 534 & 151 & 174 & 293 \\
\hline TU-185 & 7.3 & 394 & 97 & 46.5 & 221 \\
\hline \multicolumn{6}{|c|}{ Surface-water samples } \\
\hline TR@MA & 7.5 & 675 & 37 & 74.3 & 194 \\
\hline TR@NCT & 8.2 & 605 & 14 & 157 & 29.6 \\
\hline
\end{tabular}




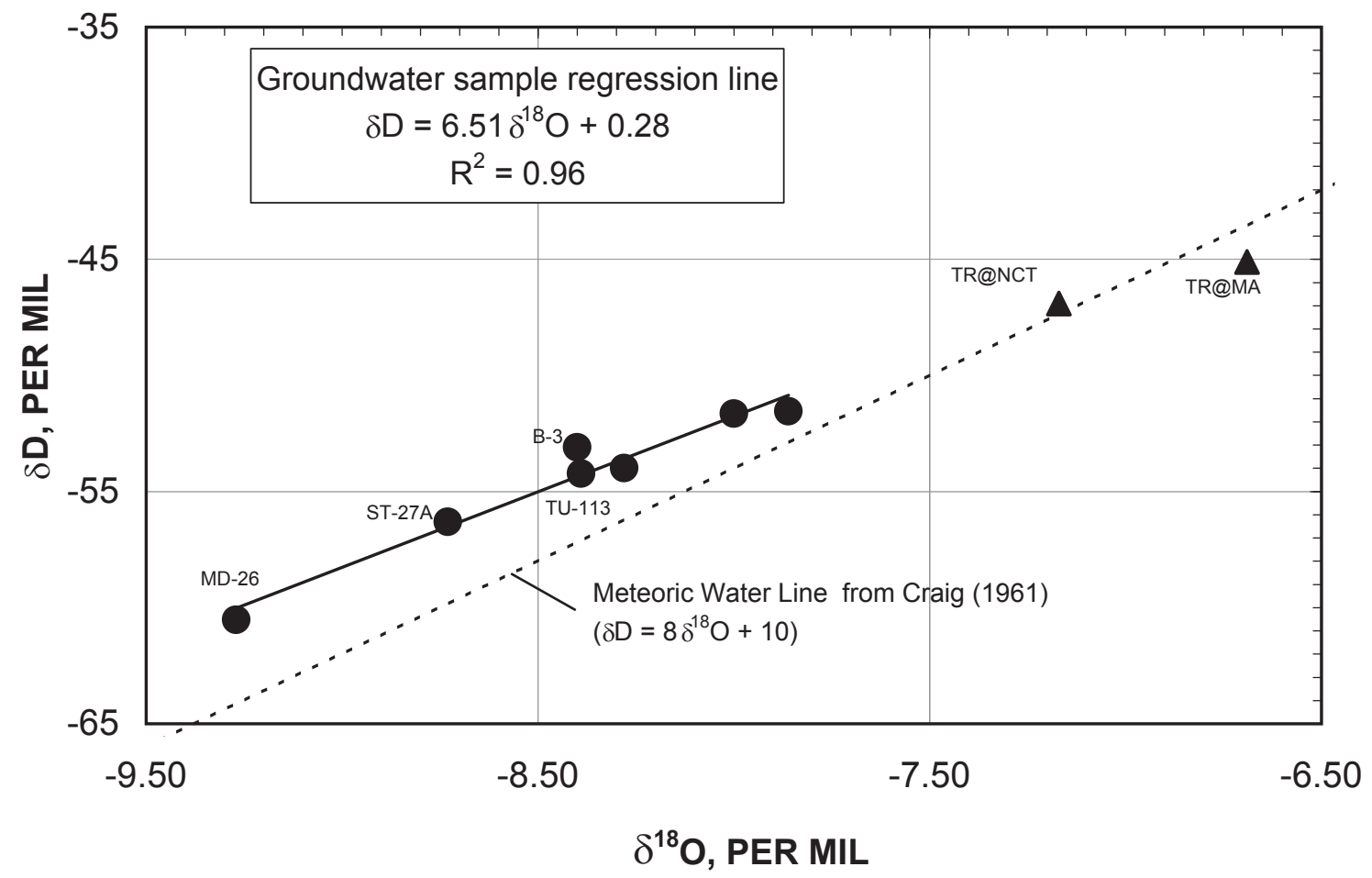

EXPLANATION
TU-184
TR@NCT

Figure 17. Relation between oxygen $\left(\delta^{18} 0\right)$ and deuterium $(\delta D)$ isotope ratios in water samples from the Tuscarawas River Basin, Ohio. (Per mil is defined as parts per thousand relative to a standard.)

\section{Status of Current Data Collection and Focus for Future Work}

The water-quality data presented above combined with data from data-collection networks that were active in 2009 provide information that is useful in understanding key issues that affect the water resources of the Tuscarawas River Basin. Of the more recently published documents that describe problems related to the water resources of the basin, the Muskingum River Basin Initiative (2005) highlights sedimentation, acid-mine drainage, hydrogen-sulfide pollution from deeper parts of oxygen-poor reservoirs, stream contamination from untreated sewage, effects of development, aging reservoirs, and recreation pressures. Furthermore, the Upper Tuscarawas River Action Plan by the Northeast Ohio Four County Regional Planning and Development Organization (1999a) cites a need to characterize critical resource areas that include high-quality waters, headwater areas, groundwater resources, biologically important wetlands, and the status of unique species and features. The Ohio Environmental Protection Agency TMDL study on the Tuscarawas River (Ohio Environmental Protection Agency, 2009c) recommends the following:
1) reducing pollutant loads and (or) increasing the capacity of streams to handle the pollutant loads, 2) addressing poorly functioning home-sewage-treatment systems, 3) practicing more environmentally sensitive turf management, 4) reducing phosphorus discharges from sewage-treatment plants, 5) controlling sediment erosion, 6) abating nutrient loading from livestock and agriculture, and 7) providing improved manure and residual nutrient management by livestock producers. The documents, maps, and Web pages described in this report indicate that water supplies from the perspective of both water quantity and water quality are adequate for current needs; however, the following water-resources issues will likely require additional focus on monitoring from decisionmakers in the future:

1. Water quality is degraded from agriculture, industry, residential land uses, and mining. Previous water-quality sampling done throughout the basin documented many different problems with both surface water and groundwater. The water sampling and extensive laboratory analysis done as part of this study showed that each of these land uses affected the water quality of at least one sample even with the relatively small sample size of two surface-water 
samples and seven groundwater samples. Among agriculture, industry, residential, and mining land uses, early mining practices continue to have a dominant effect on water quality in many areas of the basin. Both surfacewater and groundwater quality were affected by these land uses, but surface water is generally more vulnerable to contamination than groundwater because of the direct and relatively rapid overland transport of contaminants that occurs with surface runoff. Groundwater is generally less vulnerable because it moves much more slowly through soil and aquifers before reaching wells. Age-dating compounds revealed that shallow groundwater was younger than about 50 years. Therefore, it is no surprise that relatively recent land-use practices have affected groundwater quality in the basin, and future land- use practices or modifications of these practices will affect groundwater quality in the near and distant future. Improvements in, or further degradation of, shallow groundwater quality can occur relatively quickly in response to land-use modifications. Existing and future localized and basin-wide studies would likely benefit from expanding the information base with analyses similar to the ones provided in this report, thereby providing a more accurate depiction of the effects of land use on water-quality conditions throughout the basin.

2. Most of the water-quality data-collection networks in the basin provide only a snapshot of water conditions and do not provide enough data for a basin-wide assessment of water quality. In addition, continuous data is lacking through hydrologic extremes such as floods or drought As a result, the effects of extreme hydrologic events on the quality of water resources exploited for drinking or commercial uses are unknown. Additional water-quality monitors and a well-designed sampling network of surface-water and groundwater sites throughout the basin would help to address this issue.

3. Water-level data were too sparse in several areas to develop a map of groundwater levels in the basin. The map provided in this report (plate 1) is presented at a large scale that does not differentiate between water levels obtained from unconsolidated and bedrock aquifers. Additionally, the scale of the map may not be suitable for smaller-scale investigations where more accurate and timely information is needed. A basin-wide water-level synoptic study that targets wells in specific hydrogeologic settings would provide data needed for a more accurate map. Also, groundwater-flow modeling may be of use to simulate water levels in parts of the basin where data are lacking. Models calibrated to regional groundwater levels and flows are well suited to fill in the blanks in absence of other data. Tools associated with models today will be beneficial in evaluating the existing monitoring networks to identify critical locations for additions to the network to reduce uncertainty.
4. Little is known about the interaction of groundwater and surface water, including streams, lakes, and ponds in the basin. The interactions between groundwater and surface water are important for many different water-resource issues, including water quality (especially nutrients), aquatic habitat, instream flows, and groundwater recharge. Specific studies to evaluate these interactions could include streamflow gain/loss evaluations, coupled surface-water/groundwater flow models, and additional research into recharge mechanisms and rates throughout the basin.

5. Little is known about interactions between unconsolidated sand and gravel aquifers and bedrock aquifers or deeper groundwater flow that may be coming into the basin from outside the basin. The ground-water flow model by Breen and others (1995) simulated flow between the upland bedrock aquifers and unconsolidated sands and gravels in the Wooster area; however, there is no specific information for the Tuscarawas River Basin itself. Other than an anecdotal description of deeper flowpaths moving from west to east by Stout and others (1943), deeper groundwater-flow directions are poorly understood. If it is found that some of the water for public supply or commercial uses is derived from deeper sources, defining these sources would be an important step toward understanding their long-term sustainability. Groundwater-flow modeling could be an important component of future work to aid in the understanding of flow (and exchange of dissolved chemicals) between bedrock and unconsolidated aquifers.

\section{Summary}

The Tuscarawas River Basin in eastern Ohio provides water from groundwater and surface-water sources to more than 600,000 residents within a 13 -county area of approximately 2,600 square miles. The vegetation, soils, surficial deposits, and bedrock geology combined with climatic conditions and human activities help to define the sources and sinks of water throughout the basin. The primary surface-water bodies are the Tuscarawas River and the four major tributaries-Sandy Creek (with inflows from the Nimishillen Creek), Conotton Creek, Stillwater Creek, and Sugar Creek-and a series of man-made reservoirs primarily designed and maintained for flood control. The primary aquifers are sand- and gravel-filled valleys and sandstone bedrock.

Population throughout the basin is unequally distributed, with the majority of residents living near the northern headwaters. Fifty-six percent of urban land use in the basin is within two of the northern counties (Stark and Summit). In 2001, land use was dominated by 40-percent forested, 39-percent agricultural, and 17-percent urban/residential. From 1992 to 2001, only 2 percent of land that was forested was converted 
to agricultural and urban land uses. Water use was approximately $825 \mathrm{Mgal} / \mathrm{d}$ in 2000, 68 percent of which was used for thermoelectric power in coal-fired power plants in Belmont and Coshocton Counties. The second greatest water use was for public supply. Although the distributions of population, land use, and water-use in the entire Tuscarawas River Basin are complex, it is clear that these distributions in headwater areas help to define the characteristics of surface-water resources throughout the lower parts of the basin.

The effects of geological processes helped to define the basin as it is today. The topography, soils, surficial geology, and hydrology of the basin were defined by glaciation that created smooth, rolling hills in the northern, glaciated regions contrasted with relatively steep and dissected unglaciated bedrock features in the southern regions. The glacial and alluvial sand and gravel deposits that are as much as $400 \mathrm{ft}$ thick within incised valleys provide some of the best waterproducing aquifers in the State. Economic opportunities were (and continue to be) provided by the extensive oil and gas resources and coal deposits; however, extraction of these resources has altered the environment, as evidenced by oil, gas, and brine contamination of aquifers and streams, excess sedimentation in rivers, and acid-mine drainage in groundwater and surface water.

The hydrology of the basin is similar to that of other glaciated river basins in the Midwestern United States. Water budgets provided by several different sources indicate that recharge to groundwater is approximately 6 to $10 \mathrm{in}$. per year. Most of the water that enters as precipitation leaves the basin through evapotranspiration, groundwater flow, or surfacewater flow at the mouth of the Tuscarawas River in Coshocton. The new water-level map generated by the Ohio Department of Natural Resources shows that groundwater flows from the upland areas towards sand- and gravel-filled valleys, that the water- level surface mimics topography, and that several areas still remain that have inadequate water-level data to adequately map the water-level surface. Because this map focused on near-surface conditions, understanding is lacking of deeper flow conditions that might involve inflow or outflow of groundwater to or from the Tuscarawas River Basin. Datacollection networks in the Tuscarawas River Basin include meteorological stations operated by many different entities, streamgages operated by the U.S. Geological Survey and U.S. Army Corps of Engineers; groundwater observation wells operated by the Ohio Department of Natural Resources; and water-quality data collected for streams and reservoirs by the Ohio Environmental Protection Agency, the U.S. Army Corps of Engineers, and the U.S. Geological Survey. Much of the streamflow and observation-well data are collected on a continuous basis; however, water-quality data are typically collected only during scheduled sampling events that may cycle through the entire network only once every 3 to 5 years.

Water-quality data collected as part of this study include concentrations of a wide variety of constituents that were measured in samples from two surface-water sites on the Tuscarawas River and seven groundwater sites located throughout the basin. Each of the groundwater sites is representative of one or more land-use settings in the basin. For example, well HR-44, located within a forested setting had the lowest concentration of dissolved constituents and the highest concentration of dissolved oxygen compared to those for other wells sampled in the basin. Well TU-185, located in a predominantly agricultural setting had the highest nitrate concentrations. Well TU-113, located adjacent to a reclaimed coal mine, had the greatest concentrations of iron, manganese, and sulfate along with the lowest $\mathrm{pH}$ of any of the samples. These and other water-quality results indicate that the chemistry of shallow groundwater is closely related to land-use practices and that changes in land use may affect water quality over relatively short time periods.

Surface-water samples contained low levels of pesticides (including herbicides and insecticides), whereas groundwater samples did not contain any detectable pesticides. Volatile organic compounds were detected in only one sample from the Tuscarawas River at Massillon and may reflect the relatively high percentage of land identified as urban land use in the northern part of the basin. Wastewater compounds were present in only one groundwater sample (well B-3), which was likely contaminated by a variety of surface sources, including water softeners, poorly functioning septic systems, creosote, coal tar, and asphalt. Total coliform bacteria were detected in samples from two wells and both surface-water sites, and $E$. coli were detected in one of the two groundwater samples and both surface-water samples. None of the U.S. Environmental Protection Agency's Primary Maximum Contaminant Levels were exceeded in these samples; however, Secondary Maximum Contaminant Levels were exceeded for $\mathrm{pH}$, residue on evaporation, manganese, iron, and sulfate. Radon was detected in all groundwater samples: three of these samples exceeded the U.S. Environmental Protection Agency's proposed Maximum Contaminant Level of $300 \mathrm{pCi} / \mathrm{L}$ (currently under review).

The water-quality information collected as part of this study, combined with age-dating tracers that include chlorofluorocarbons, sulfur hexafluoride, and tritium/helium, indicate that shallow groundwater was recharged from local sources with relatively short residence times of less than 50 years. In the Tuscarawas River Basin, CFCs were degraded under anoxic conditions. Helium in groundwater derived from deeper natural-gas deposits and (or) storage reservoirs interfered with tritium/helium age determinations, but corrections for this excess helium were applied so that these data were still useful. Thus, although a multitude of tracers helps define the overall hydrogeochemical conditions in groundwater, sulfur hexafluoride and tritium/helium may be the most useful agedating tracers to include in future characterizations of aquifers in the basin.

The compilation of published and unpublished literature related to the hydrology of the basin shows that although substantial amounts of data and accompanying reports have been produced, there are few reports that consider the water resources of the basin as a whole. The Muskingum River 
Basin Initiative (2005), the Upper Tuscarawas River Basin Action Plan (Northeast Ohio Four County Regional Planning and Development Organization, 1999a), and a series of Ohio Environmental Protection Agency reports provide valuable data for understanding the status of water resources in the basin. These and other studies support the conclusion that, in general, water resources are abundant in the basin, but waterquality issues resulting from agriculture, industry, residential land uses, and mining have caused problems in the past and will likely continue to affect decisions regarding water resources in the future.

The major conclusions of the current study are that (1) water quality is degraded from agriculture, industry, residential land uses, and mining; (2) most of the water-quality data-collection networks in the basin provide only a snapshot of water conditions and do not provide a basin-wide assessment of conditions or continuous data through hydrologic extremes such as floods or drought; (3) water-level data were too sparse in some areas of the basin to develop a map of groundwater levels; (4) little is known about the interaction of groundwater and surface water, including streams, lakes, and ponds in the basin; and (5) little is known about interactions between unconsolidated sand and gravel aquifers and bedrock aquifers, or about deep groundwater flow that may be entering the basin from outside of the basin.

\section{Acknowledgments}

The authors would like to thank the Stark-TuscarawasWayne Joint Solid Waste Management District for their support and patience throughout this effort. Additionally, the authors appreciate assistance from the Ohio Department of Natural Resources and the Ohio Environmental Protection Agency during the process of well selection for groundwater sampling, generation of the enclosed water-level map, and installation of monitoring wells in the basin. Stephanie Kula, a biologist with the U.S. Geological Survey Ohio Water Science Center, assisted greatly in the final compilation of population, land use, and GIS datasets for this report.

\section{Annotated Bibliography}

Adolphson, D.L., Arnold, T.L., Fitzpatrick, F.A., Harris, M.A., Richards, K.D., Scudder, B.C., and Stewart, J.S., 2002, Physical, chemical and biological methods and data from the urban land-use-gradient study, Des Plaines and Fox River Basins, Illinois, 1999-2001: U.S. Geological Survey Open-File Report 01-459, 20 p.

Akin, E., 2006, Nimishillen Creek Watershed State Action Plan: Northeast Ohio Four County Regional Planning and Development Organization, 235 p., accessed October 12, 2006, at http://www.uptuscwatershed.org/nim_state_action_ plan.htm
A watershed action plan that includes background hydrologic data designed to protect and restore the water quality of Nimishillen Creek (north central Tuscarawas Basin). The plan includes extensive data on watershed characteristics, geology, soils, biology, and water-quality issues. Over half the basin is unsewered (p. 69). Water-quality issues include nutrients, pesticides, organic wastes, and disease-causing organisms. "...The impact of agricultural areas is gradually decreasing as agricultural areas are converted to residential, commercial, or industrial areas."

Allen, R.G., Pereira, L.S., Raes, D., and Smith, M., 1998, Crop evapotranspiration - guidelines for computing crop water requirements: Food and Agriculture Organization of the United Nations Irrigation and Drainage Paper 56, Rome, Italy, ISBN 92-5-104219-5, accessed June 29, 2009, at http://www.fao.org/docrep/X0490E/x0490e00.HTM

Aller, L., Bennett, T., Lehr, J.H., and Petty, R.J., 1985, DRASTIC - a standardized system for evaluating ground water pollution potential using hydrogeologic settings: U.S. Environmental Protection Agency, Robert S. Kerr Environmental Research Laboratory, Office of Research and Development, EPA/600/2-85/018, 163 p.

Angelo, C.G., and Youger, J.D., 1985, Chemical and biological quality of selected lakes in Ohio, 1978 and 1979: U.S. Geological Survey Open-File Report 84-249, 294 p.

Angle, M.P., 1990, Ground water pollution potential of Portage County, Ohio: Ohio Department of Natural Resources, Division of Water, Ground Water Pollution Potential Report 22, 292 p., accessed August 8, 2006, at http://www.dnr.state. oh.us/water/gwppmaps.

This report includes general and pesticide DRASTIC (an acronym for Depth to water, net Recharge, Aquifer media, Soil media, Topography, Impact of the vadose zone media, hydraulic Conductivity of the aquifer) maps for Portage County. The DRASTIC process includes designating mapable units and assigning a relative rating system to aquifers for potential. The acronym DRASTIC applies to Depth to water, net recharge, aquifer media, soil media, topography, impact of vadose-zone media, and hydraulic conductivity. The weights assigned to the DRASTIC factors were changed to reflect the processes that affect pesticide movement into the subsurface with particular emphasis on soils. Pollution potential index for the Tuscarawas River Basin ranges from 140 to more than 200. The pesticide potential index ranges from 160 to more than 200 (medium to high).

Angle, M.P., 1994a, Ground water pollution potential of Columbiana County, Ohio: Ohio Department of Natural Resources, Division of Water, Ground Water Pollution Potential Report 35, 105 p., accessed September 18, 2006, at http://www.dnr.state.oh.us/water/gwppmaps 
Angle, M.P., 1994b, Ground water pollution potential of Medina County, Ohio: Ohio Department of Natural Resources, Division of Water, Ground Water Pollution Potential Report 13, 87 p., accessed September 18, 2006, at http://www.dnr.state.oh.us/water/gwppmaps

Pollution potential indexes are relatively low to moderate in areas of till or lacustrine cover over bedrock. Buried valleys containing sand and gravel aquifers, and areas covered by outwash, have moderate to high vulnerabilities to contamination.

Angle, M.P., 2006a, Potentiometric surface of the consolidated aquifers in Carroll County: Ohio Department of Natural Resources, Division of Water, accessed February 15, 2008, at http://www.dnr.state.oh.us/portals/7/gwpsurface/ PSurfPDFs/CarrollBed_PSurf.pdf

This map shows potentiometric contours of static water levels with a contour interval of $50 \mathrm{ft}$ in the consolidated (bedrock) aquifers of Carroll County, created from data collected over a 50 -yr period.

Angle, M.P., 2006b, Potentiometric surface of the unconsolidated aquifers in Carroll County: Ohio Department of Natural Resources, Division of Water, accessed February 15, 2008, at http://www.dnr.state.oh.us/portals/7/gwpsurface/ PSurfPDFs/CarrollSG_Psurf.pdf

This map shows potentiometric contours of static water levels with a contour interval of $25 \mathrm{ft}$ in the unconsolidated (sand and gravel) aquifers of Carroll County created from data collected over a 50 -yr period.

Angle, M.P., 2006c, Potentiometric surface of the unconsolidated aquifers in Stark County: Ohio Department of Natural Resources, Division of Water, accessed February 15, 2008, at http://www.dnr.state.oh.us/portals/7/gwpsurface/ PSurfPDFs/StarkSG_Psurf.pdf

This map shows potentiometric contours of static water levels with a contour interval of $25 \mathrm{ft}$ in the unconsolidated (sand and gravel) aquifers of Stark County created from data collected over a 50 -yr period.

Angle, M.P., Spahr, P.N., Fugitt, F.L., Hallfrisch, M.P., and Pendley, K.R., 2000, Hydrogeologic settings of the unconsolidated aquifers of Ohio: Ohio Department of Natural Resources, Division of Water, accessed October 12, 2006, at http://www.dnr.state.oh.us/water/samp/sampuchydro.pdf

Map files of consolidated and unconsolidated aquifers are available as PDF files or GIS data sets and can be downloaded from http://www.dnr.state.oh.us/water/samp/. Data also can be ordered on a $\mathrm{CD}$ that contains additional base map files and supporting documentation.

Angle, M.P., and Baker, J., 2001, Ground water pollution potential of Tuscarawas County, Ohio: Ohio Department of Natural Resources, Division of Water, Ground Water Pol- lution Potential Report 52, 53 p., accessed September 18, 2006, at http://www.dnr.state.oh.us/water/gwppmaps

Angle, M.P., and Akins, M., 2002, Ground water pollution potential of Wayne County, Ohio: Ohio Department of Natural Resources, Division of Water, Ground Water Pollution Potential Report 22, 292 p., accessed September 18, 2006, at http://www.dnr.state.oh.us/water/gwppmaps

Angle, M.P., and Bonifas, C., 2002, Ground water pollution potential of Holmes County, Ohio: Ohio Department of Natural Resources, Division of Water, Ground Water Pollution Potential Report 58, 57 p., accessed August 8, 2006, at http://www.dnr.state.oh.us/water/gwppmaps

Angle, M.P., and Jonak, J., 2002, Ground water pollution potential of Belmont County, Ohio: Ohio Department of Natural Resources, Division of Water, Ground Water Pollution Potential Report 50, 39 p., accessed September 18, 2006, at http://www.dnr.state.oh.us/water/gwppmaps/PDF_ GISMap_wReport/Belmont_PP_report_wMap.pdf

Angle, M.P., and Walker, D., 2002, Ground water pollution potential report of Harrison County, Ohio: Ohio Department of Natural Resources, Division on Water, Ground Water Pollution Potential Report 56, 40 p., accessed September 18, 2006, at http://www.dnr.state.oh.us/water/gwppmaps

Angle, M.P., Russel, C., and Ziss, B., 2003a, Ground water pollution potential report of Summit County, Ohio: Ohio Department of Natural Resources, Division of Water, Ground Water Pollution Potential Report 49, 85 p., accessed September 18, 2006, at http://www.dnr.state.oh.us/water/ gwppmaps

Angle, M.P., Ziss, B., and Corbin, S., 2003b, Ground water pollution potential report of Carroll County, Ohio: Ohio Department of Natural Resources, Division of Water, Ground Water Pollution Potential Report 59, 57 p., accessed September 18, 2006, at http://www.dnr.state.oh.us/water/ gwppmaps

Axon, A.G., 1996, Available coal resources of the Bethesda 7.5-minute quadrangle, Belmont County, Ohio: Ohio Department of Natural Resources Report of Investigation $145,27 \mathrm{p}$.

Babington, W.M., and Fisher, L.R.J., 1977, Total Water System (AT) Coshocton Mill (OF) April 25-27, 1977): Chicago, Stone Container Corporation, p. 25-31.

Stone Container Corp. operated a 640 ton/day neutral sulfite semichemical corrugating medium mill at Coshocton, Ohio. Low-quality process water used in the chemical recovery system was supplied by a shallow well system. High-quality process water was obtained by processing sludge produced in the city's water-treatment plant. Clarifier sludge and thickened municipal lime sludge were centrifuged together, and the clarifier overflow was pumped to an aerated lagoon 
equipped with floating mechanical aerators. Lagoon effluent was discharged directly into the Tuscarawas River.

Bachman, J.S., and Morgan, J.R., 1983, Conventional water treatment process operates in unconventional manner: Public Works, v. 114, no. 3, p. 50-53.

Following studies on the upgrading of the water works of New Philadelphia, Ohio, a pressure ion-exchange process of water softening was introduced. The new process involved split-stream softening with about 80 percent of the supply being softened and the remainder being treated for removal of iron and manganese. The waste brine was discharged to the Tuscarawas River.

Bair, E.S., and Norris, S.E., 1989, Ground-water levels and flow near the Industrial Excess Landfill, Uniontown, Ohio: U.S. Geological Survey Open-File Report 89-272, 11 p.

This is an evaluation of geologic and hydrogeologic data available for the Industrial Excess Landfill (IEL) site in Uniontown, Ohio. Groundwater flows radially away from the site, primarily to the northwest and to the southeast. Available data also indicate a downward flow component within the glacial-drift aquifer, which indicate a local recharge area within the regional flow system. Therefore, contaminants present at the site may flow both laterally within the local flow patterns and vertically downward within the flow system.

Baranoski, M.T., 2002, Structure contour map on the Precambrian unconformity surface in Ohio and related basement features: Ohio Department of Natural Resources Division of Geological Survey Map PG-23, 27 p.

This map provides a detailed description of the surface of the Precambrian rocks in the basin. The map shows that the bedrock surface on top of Precambrian metamorphic and igneous rocks lies between 5,500 and 10,000 ft below sea level and dips to the southeast at approximately $60 \mathrm{ft}$ per mile.

Barber, D.J., 1989, Ground-water resources of Tuscarawas County: Ohio Department of Natural Resources, Division of Water, scale 1:62,500, accessed August 8, 2006, at http://www.dnr.state.oh.us/water/gwrmaps/

Barber, T.R., Fuchsman, P.C., Chappie, D.J., Sferra, J.C., Newton, F.C., and Sheehan, P.J., 1997, Toxicity of hexachlorobenzene to Hyalella Azteca and Chironomus Tentans in spiked sediment bioassays: Environmental Toxicology and Chemistry, v. 16, no. 8, p. 1716-1720.

Bartlett, W.P., Jr., Krejmas, B.E., Mayo, R.I., and Wandle, S.W., Jr., 1984, Effects of relocating State Route 151 on the flood profiles of Conotton Creek and its tributaries between Bowerston and Scio, Ohio: U.S. Geological Survey WaterResources Investigations Report 83-4130, 46 p.
This report indicates that water-surface profiles would be virtually the same before and after road rerouting. Upstream sections would result in water-surface profiles about a foot lower.

Barton, G.J., Burruss, R.C., and Ryder, R.T., 1998, Water quality in the vicinity of Mosquito Creek Lake, Trumbull County, Ohio, in relation to the chemistry of locally occurring oil, natural gas, and brine: U.S. Geological Survey Water-Resources Investigations Report 98-4180, 46 p.

Bauder, J.R., 1994, Unusual dewatering of a wetland, Summit County, Ohio [abs]: The Ohio Journal of Science, v. 94, no. 2, p. 29,

Land-use changes, including construction of roads that acted to intercept surface-water flows, installation of industrial well fields, and construction of a long dike between the Tuscarawas River and its former flood plain caused dewatering of a wetland.

Beck, T., Boone, K.M., and Brown, L.C., undated a, Wayne County water resources: Ohio State University Extension Fact Sheet AEX-480.85, accessed November 20, 2006, at http://ohioline.osu.edu/aex-fact/0480_85.html

Overview of water resources for Wayne County, including precipitation, groundwater, surface water, water use, and water quality. Average rainfall for the county is 36 inches per year, providing 9 inches of runoff to streams and lakes. About 6 inches per year has the potential to recharge aquifers. Land use is 75 percent rural. The report states that elevated nitrate concentrations are an issue.

Beck, T., Raab, J.M., Boone, K.M., and Brown, L.C., undated b, Wayne County ground-water resources: Ohio State University Extension Fact Sheet AEX-490.85, accessed November 20, 2006, at http://ohioline.osu.edu/aexfact/0490_85.html

This fact sheet gives an overview of Wayne County's groundwater resources, including definitions of aquifer and well yield. On a generalized map of well yields, Ohio Department of Natural Resources observation wells and chemical analysis sites are shown. Land use is more than 70 percent farmland. Total dissolved solids and iron are a problem in ground water.

Black, L.P., 1991, Natural lakes in Ohio (larger than five acres): Ohio Department of Natural Resources, Division of Water, Open File Report 5, 13 p.

The vast majority of Ohio's natural lakes were formed after glaciation; a few are of post-glacial origin created from cutoff stream oxbows. Lakes greater than 5 acres are listed by county and township. Within the Tuscarawas River Basin (and within Ohio), Summit County has the most lakes, 34, and Portage County has 16 . Portage County has the greatest area, 1,493 acres, covered by natural lakes, followed by Summit County, 1,216 acres, and Stark County, 452 acres. 
Böhlke, J. K., 2006, Tracermodel1- Excel workbook for calculation and presentation of environmental tracer data for simple groundwater mixtures: Use of chlorofluorocarbons in hydrology - a guidebook, Section III.10.3: Vienna, Austria, International Atomic Energy Agency STI/PUB/1238, p. 239-S243.

Bonn, B.A., 2008, Using the U.S. Geological Survey National Water Quality Laboratory LT-MDL to evaluate and analyze data: U.S. Geological Survey Open-File Report 2008-1227, $73 \mathrm{p}$.

Bonta, J.V., and Muller, M., 1999, Evaluation of the Glugla method for estimating evapotranspiration and groundwater recharge: Hydrological Sciences Journal, v. 44, no. 5, p. 743-S761.

The Glugla method was used for estimating long-term groundwater recharge and actual evapotranspiration using long-term average annual precipitation, runoff, potential evaporation, and crop-yield information along with empirical parameter curves that depend on soil and crop types. Table 2 on page 753 shows measured values from 10 Coshocton lysimeters: annual evapotranspiration ranges from 25.9 to $35.8 \mathrm{in} / \mathrm{yr}$, and groundwater recharge ranges from 5.5 to $15.4 \mathrm{in} / \mathrm{yr}$. The Glugla computations differ by -7 percent to +12 percent for evapotranspiration and -19 to +34 percent for recharge.

Booth C.J., 1988, Interpretation of well and field data in a heterogeneous layered aquifer setting, Appalachian Plateau: Ground Water, v. 26, no. 5, p 597-606.

Botoman, G., and Stieglitz, R.D., 1978, The occurrence of sulfide and associated minerals in Ohio: Ohio Department of Natural Resources Report of Investigation 104, 11 p.

Botoman, G., and Stith, D.A., 1978, Analyses of Ohio coals: Ohio Department of Natural Resources Information Circular $47,148 \mathrm{p}$.

Botoman, G., and Stith, D.A., 1981, Analyses of Ohio coals, 1977-1978: Ohio Department of Natural Resources Information Circular 50, 51 p.

Botoman, G., and Stith, D.A., 1986, Analyses of Ohio coals, 1979-1980: Ohio Department of Natural Resources Information Circular 52, 26 p.

Botoman, G., and Stith, D.A., 1988, Analyses of Ohio coals, 1982-1984: Ohio Department of Natural Resources Information Circular 55, 17 p.

Bowell, D.F., 1980, Inventory of Ohio's lakes: Ohio Department of Natural Resources, Division of Water, Ohio Water Inventory Report 26, $282 \mathrm{p}$.

The report lists all of Ohio's impoundments (natural or otherwise) greater than 5 acres, plus contributing streams, drainage basin, year of completion, purpose(s), surface areas, and remarks.
Bownocker, J.A., 1903, The occurrence and exploitation of petroleum and natural gas in Ohio: Ohio Department of Natural Resources Bulletin 1, 325 p.

Bownocker, J.A., and Dean, E.S., 1929, Analyses of the coals of Ohio: Ohio Department of Natural Resources Bulletin 34, 360 p.

Bownocker, J.A., Lord, N.W., and Somermeier, E.E., 1908, Coal: Ohio Department of Natural Resources Bulletin 9, $342 \mathrm{p}$.

Bownocker, J.A., and Stout, W., 1928, Mineral industries of Ohio: Ohio Department of Natural Resources Bulletin 33, $94 \mathrm{p}$.

Boyce, T.F., Smith, T.R., and Baker, F.J., 1960, Tuscarawas River Basin (upper portion) soil conservation needs: Ohio Department of Natural Resources, Division of Water, Ohio Water Plan Inventory File Index P-6A.

Bragg, L.J., Oman, J.K., Tewalt, S.J., Oman, C.L., Rega, N.H., Washington, P.M., and Finkelman, R.B., 1998, U.S. Geological Survey Coal Quality (COALQUAL) Database: Version 2.0: U.S. Geological Survey Open-File Report 97-134, accessed November 27, 2007, at http://energy.er.usgs.gov/ products/databases/CoalQual/index.htm

This report describes an extensive geochemical database containing analysis of Ohio coals.

Bralek, R., Steer, D., and Fraser, L., 2002, Performance of constructed wetlands for treatment of acid mine drainage in Ohio: Geological Society of America North-Central Section (36th) and Southeastern Section (51st), GSA Joint Annual Meeting (April 3-5, 2002), Program with Abstracts, Paper 48-0.

Brant, R.A., 1954, The Lower Kittanning No. 5 coal bed in Ohio: Ohio Department of Natural Resources Report of Investigation 21, 59 p., 13 figs., 31 tables.

Brant, R.A., 1956, Coal resources of the upper part of the Allegheny formation in Ohio: Ohio Department of Natural Resources Report of Investigation 29, 68 p., 19 figs., 52 tables.

Brant, R.A., and DeLong, R.M., 1960, Coal resources of Ohio: Ohio Department of Natural Resources Bulletin 58, 245 p., 22 figs., 38 tables.

Brasaemle, J.E., Corbett, R.G., Manner, B.M., 1979, Groundwater quality of Bath, Boston, Northampton, and Richfield Townships, Summit County, Ohio: Akron, Ohio, University of Akron Department of Geology.

Breen, K.J., Angelo, C.G., Masters, R.W., and Sedam, A.C., 1985, Chemical and isotopic characteristics of brines from three oil- and gas-producing formations in eastern Ohio, with applications to the geochemical tracing of brine 
sources: U.S. Geological Survey Water-Resources Investigations Report 84-4314, 58 p.

Breen, K.J., Kontis, A.L., Rowe, G.L., and Haefner, R.J., 1995, Simulated ground-water flow and sources of water in the Killbuck Creek Valley near Wooster, Wayne County, Ohio: U.S. Geological Survey Water-Resources Investigations Report 94-4131, 104 p.

This report describes water-quality data and groundwaterflow simulations to help in the understanding of the sources of water in Killbuck Creek. Influx of water into the valley is controlled, in part, by pumping stresses placed on the glacial stratified drift aquifer. Quality of water in the stratified drift is affected by influx of water from bedrock. Recharge characteristics were investigated with the variable recharge procedure, which allows for water to infiltrate the aquifer or be rejected based on the water level in the aquifer. Isotopic compositions of streamwater and streambed water show that the transport time from the streams to the stratifieddrift aquifer ranges from several days to several weeks. The chemical and isotopic data indicate that the streamwater is diluted and mixed with ground water and dispersed within the stratified drift such that it is chemically and isotopically unrecognizable as streamwater at the production wells. The time estimated for infiltrating streamwater to reach the shallow groundwater system beneath the stream is likely 2 months.

Busenberg, E., Weeks, E.P., Plummer, L.N., and Bartholemay, R.C., 1993, Age dating ground water by use of chlorofluorocarbons $\left(\mathrm{CCl}_{3} \mathrm{~F}\right.$ and $\left.\mathrm{CCl}_{2} \mathrm{~F}_{2}\right)$, and distribution of chlorofluorocarbons in the unsaturated zone, Snake River Plain aquifer, Idaho National Engineering Laboratory, Idaho: U.S. Geological Survey Water-Resources Investigations Report 93-4054, 47 p.

Busenberg E., and Plummer, L.N., 2000, Dating young ground water with sulfur hexafluoride: Natural and anthropogenic sources of sulfur hexafluoride: Water Resources Research, v. 36 , no. 10 , p. 3011-3030.

Busenberg E., and Plummer, L.N., 2008, Dating groundwater with trifluoromethyl sulfurpentafluoride $\left(\mathrm{SF}_{5} \mathrm{CF}_{3}\right)$, sulfur hexafluoride $\left(\mathrm{SF}_{6}\right), \mathrm{CF}_{3} \mathrm{Cl}(\mathrm{CFC}-13)$, and $\mathrm{CF}_{2} \mathrm{Cl}_{2}(\mathrm{CFC}-12)$ : Water Resources Research, v. 44, W02431, 18 p.

Cady, G.H., and Smith, G.E., 1955, Petrographic constitution of the Meigs Creek No. 9 coal bed: Ohio Department of Natural Resources Report of Investigation 27, 97 p.

Calvert, W.L., 1963, Sub-Trenton rocks of Ohio in cross sections from West Virginia and Pennsylvania to Michigan: Ohio Department of Natural Resources Report of Investigation $49,5 \mathrm{p}$.

Carlson, E.H., 1991, Minerals of Ohio: Ohio Department of Natural Resources Bulletin 69, 155 p.
Carroll County Regional Planning Commission, 2004, Carroll County sustainable comprehensive plan (draft): Carroll County Regional Planning Commission, variously paginated, accessed September 26, 2006, at http://www. carrollcountyohio.net/planning/index.htm

This is a county-wide plan intended to address naturalresource impairment through a series of goals, objectives, and strategies. The plan lists 15 sources of water impairment for Carroll County, including agricultural production, atmospheric deposition, land development, contaminated sediments, combined sewer overflows, industrial point sources, land disposal of wastewater, marinas, municipal discharge, natural sources, nonpoint sources, mining, septic systems, forestry silviculture, and urban runoff.

Cassidy, H., Dobkin, A., and Wetzel, R., 1930, A study of the food of three species from the Portage Lakes, Ohio (fish): Ohio Journal of Science, v. 30, no. 3, p. 194-198.

Minnow species eat midge larvae, small crustaceans, small snails, and plankton.

Childress, C.J.O., Foreman, W.T., Connor, B.F., and Maloney, T.J., 1999, New reporting procedures based on longterm method detection levels and some considerations for interpretations of water-quality data provided by the U.S. Geological Survey National Water Quality Laboratory: U.S. Geological Survey Open-File Report 99-193, 19 p.

Chowdhury, S.H., 1995, Hydrogeology and groundwater pollution potential of Chippewa Creek Basin, Wayne County, Ohio: Akron, Ohio, University of Akron, M.S. thesis, p. 176.

Chowdhury, S.H., Iqbal, M.Z., and Szabo, J.P., 2003, Comprehensive approach of groundwater resource evaluation: a case study in the Chippewa Creek Watershed in Ohio: Ohio Journal of Science, v. 103, no. 5, p. 134-42.

Well-log data were used to compute mean transmissivity of outwash along Chippewa Creek in Wayne and Medina Counties. Transmissivity of the outwash was computed to be $25,000 \mathrm{gal} / \mathrm{d} / \mathrm{ft}\left(310 \mathrm{~m}^{2} / \mathrm{d}\right)$ and hydraulic conductivity was $250 \mathrm{gal} / \mathrm{d} / \mathrm{ft}^{2}(10 \mathrm{~m} / \mathrm{d})$. Annual recharge was estimated to be $4.2 \times 10^{8} \mathrm{ft}^{3}$, and specific capacity was $5 \mathrm{gal} / \mathrm{min} / \mathrm{ft}$ $(1.03 \mathrm{l} / \mathrm{sec} / \mathrm{m})$. Groundwater quality has elevated concentrations of calcium, sodium, potassium, and bicarbonate. The article states that there is no significant variation in water quality across the study area based on analysis of 18 water samples. DRASTIC results showed that the potential for contamination is highest along Chippewa Creek within the outwash. The authors concluded that a comprehensive evaluation of an aquifer for development should include not only dimensions and hydraulic properties, but also its long term susceptibility to contamination.

Cleveland Museum of Natural History, 2008, Singer Lake Bog, accessed March 11, 2008, at http://www.cmnh.org/site/ Conservation_NaturalAreas_Map_SingerLakeBog.aspx 
Clifford, M.J., 1973, Silurian rock salt of Ohio: Ohio Department of Natural Resources Report of Investigation 90, 42 p.

Clifford, M.J., 1975, Subsurface liquid-waste injection in Ohio: Ohio Department of Natural Resources Information Circular 43, 27 p.

Coffey, G., 1930, Preglacial, interglacial and postglacial changes of drainage in northeastern Ohio with special reference to the Upper Muskingum Drainage Basin: The Ohio Journal of Science, v. 30, no. 6, p. 373-384.

This is an early attempt to understand existing and historical directions of surface drainage. "Still much to be done (1930) before a complete and satisfactory explanation of direction of flow of streams either in new channels or the flow direction has been reversed. The general direction of flow within preglacial streams was from the southeast northwestward toward the broad plains to the west rather than from the edge of the plains southeastward into the hills as so many of them do at the present time."

Cohen, A.J., and Randall, A.D., 1998, Mean annual runoff, precipitation, and evapotranspiration in the glaciated northeastern United States, 1951-80: U.S. Geological Survey Open-File Report 96-395 (digital version of map data), accessed June 29, 2009, at http://water.usgs.gov/lookup/ getspatial?ofr96395_eva

Condit, D.D., 1912, Conemaugh Formation in Ohio: Ohio Department of Natural Resources Bulletin 17, 363 p.

This report provides detailed descriptions of the Conemaugh Formation in eastern Ohio. The formation is middle to upper Pennsylvanian in age (roughly 300 to 360 million years old). The Pottsville Formation is basal (oldest), overlain by the Allegheny Formation, overlain by the Conemaugh Formation, overlain by the Monongahela (youngest). Descriptions of rock outcrops, cores, and fossil assemblages are given, by county.

Conrey, G.W., 1921, Geology of Wayne County: Ohio Department of Natural Resources Bulletin 24, 155 p.

The report provides descriptions of rock cores and outcrops of formations throughout Wayne County, by township.

Cook, P.G., and Solomon, D.K., 1995, Transport of atmospheric trace gases to the water table: Implications for groundwater dating with chlorofluorocarbons and krypton 85: Water Resources Research, v. 31, no. 2, p. 263-270.

Couchot, M.L., 1978, Resources of the Pittsburgh (No. 8) coal in the Belmont field, Ohio: Ohio Department of Natural Resources Report of Investigation 105, 12 p.

Couchot, M.L., Crowell, D.L., Van Horn, R.G., and Struble, R.A., 1980, Investigation of the deep coal resources of portions of Belmont, Guernsey, Monroe, Noble, and Washington Counties, Ohio: Ohio Department of Natural Resources Report of Investigation 116, 37 p.
Craig, H., 1961, Isotopic variations in meteoric water: Science, v. 133, p. 1702-1703.

Crist, D.R., and Raab, J.M., 2006, Potentiometric surface of the consolidated aquifers in Stark County: Ohio Department of Natural Resources, Division of Water, accessed February 15, 2008, at http://www.dnr.state.oh.us/portals/7/ gwpsurface/PSurfPDFs/StarkBed_PSurf.pdf

This map shows potentiometric contours of water levels in the consolidated (bedrock) aquifers of Stark County created from data collected over a $50-y r$ period with a contour interval of $50 \mathrm{ft}$.

Cross, W.P., and Brooks, H.P., 1959, Floods of January-February 1959 in Ohio: U.S. Geological Survey Circular 418, $54 \mathrm{p}$.

The 1959 flood was reported to be the worst flood in Ohio since 1913. Heavy rains on January 20 and 21, 1959, exceeded 6 inches. In addition, there was already high runoff because the ground was saturated by a storm on January 14-17 and was frozen with some ground cover. On a few streams, the stages and discharges exceeded those of 1913. Sixteen lives were lost and the damage was estimated at $\$ 100$ million. Total damage in the Muskingum River basin exceeded that of any other major river basin. The report also provides discharge and stage data for several gages within the Tuscarawas River Basin and runoff into the major reservoirs.

Crouch, T.M., Collins, H.R., and Helgeson, J.O., 1980, Abandoned subsurface coal mines as a source of water for coal conversion in eastern Ohio: Ohio Department of Natural Resources Report of Investigation 118, 25 p.

Crowell, D.L., 1995, History of the coal-mining industry in Ohio: Ohio Department of Natural Resources Bulletin 72, $204 \mathrm{p}$.

Crowell, K., and Crumley, T.A., 1978, Ground-water resources of Columbiana County: Ohio Department of Natural Resources, Division of Water, scale approx. 1:63,000.

Crowell, K., and Schottenstein, C.A., 1979a, Ground-water resources of Holmes County: Ohio Department of Natural Resources, Division of Water, scale approx. 1:63,000.

Crowell, K., and Schottenstein, C.A., 1979b, Ground-water resources of Wayne County: Ohio Department of Natural Resources, Division of Water, scale approx. 1:63,000.

A color-coded county map, based on 8,900 water-well records, shows the diversity of well-yield conditions, ranging from 300 to $500 \mathrm{gal} / \mathrm{min}$ within permeable sands and gravels in deep buried valleys to less than $10 \mathrm{gal} / \mathrm{min}$ in sand and gravel stringers in thick clayey till. Most of the bedrock areas of the map provide 10 to $25 \mathrm{gal} / \mathrm{min}$ from the Pottsville and Allegheny groups and as much as 25 to $100 \mathrm{gal} / \mathrm{min}$ from sandstones in the Pottsville group. 
An important note is included on the map: "High density housing may substantially reduce projected well yields."

Crowell, K., and Schottenstein, C.A., 980, Ground-water resources of Harrison County: Ohio Department of Natural Resources, Division of Water, scale approx. 1:63,000.

This groundwater resource map shows approximate groundwater yield based on well logs and aquifer tests. The map is dominated by areas colored orange, where wells produce less than $3 \mathrm{gal} / \mathrm{min}$. Sandstones and sandy shales present in northwest corner of the county near Bowerston may yield 3 to $10 \mathrm{gal} / \mathrm{min}$. Valleys have clay fine sand and silt with smaller amounts of sand and gravel.

Cummins, J.W., 1959, Buried Valleys in Ohio: Ohio Department of Natural Resources, Division of Water, Ohio Water Plan Inventory Report No. 10.

This report provides maps of buried valleys in Ohio along with their estimated water-yielding properties.

Cummins, J.W., and Sanderson, E.E., 1947, The water resources of Tuscarawas County, Ohio: Ohio Water Resources Board Bulletin 6, 52 p.

Hydrologic conditions in Tuscarawas County through the 1940s are described. The 1940 census lists a population at 68,816 with 54.5 percent of the population living in an urban setting and 45.5 percent in a rural setting. Twentyseven percent of county land is under agricultural production. In 1945, 1.7 million tons of coal was mined from 82 active mines; 4 billion cubic feet of gas and 30,000 barrels of oil were extracted.

Springs were numerous and occurred at outcrops of sandstone with flows up to $20 \mathrm{gal} / \mathrm{min}$. Water use in the county was estimated to be $18.7 \mathrm{Mgal} / \mathrm{d}$ (million gallons per day). Favorable areas for induced streamflow to wells lie along Tuscarawas River from Newcomerstown to Dover and Bolivar. However, on p. 39 it is noted that... "In view of the present high chloride content of the Tuscarawas River, such developments, along that stream would probably yield undesirable water." Movement of ground water in bedrock is generally from west to east with discharge into gravel strata in buried valleys. East of the Tuscarawas River, these strata have no area of natural discharge and the water is highly mineralized. In the sand and gravel deposits, "no particle of water moves down valley very far before it discharges to the stream." No wells show long-term waterlevel declines, but fluctuations may be as large as $16 \mathrm{ft}$.

Analyses of groundwater revealed iron concentrations greater than $1 \mathrm{ppm}$ (parts per million) in sandstone aquifers and elevated chloride concentrations in samples from the Blackhand Sandstone. Surface-water samples from the Tuscarawas River sometimes exceed 12,000 ppm of chloride, resulting in contamination of the Coshocton Wellfield. Water samples collected during low flow in the upper tributaries and reaches of the Tuscarawas are high in noncarbonate hardness, chloride, and dissolved solids. Concentrations of total hardness, chloride, and dissolved solids become lower in downstream reaches; however, the chloride concentration in the Tuscarawas River at Newcomerstown varies greatly.

Dachnowski, A., 1912, Peat deposits of Ohio, their origin, formation and uses: Ohio Department of Natural Resources Bulletin 16, $424 \mathrm{p}$.

Dai, J., 1993, Groundwater characteristics and lead geochemistry, Sandy Creek, Ohio: Akron, Ohio, University of Akron, M.S. thesis, $59 \mathrm{p}$.

Dai, J., Chyi, L.L., and Khourey, C.J., 1992, Characteristics of groundwater and lead geochemistry along the Sandy Creek, Ohio [abs]: Abstracts with Programs - Geological Society of America, v. 24, no. 7, p. 211.

Dames \& Moore and U.S. Army Corps of Engineers Huntington District, 1975, Muskingum River Basin Flood Control System: Muskingum River Basin, Ohio: Huntington, W. Va., U.S. Army Engineers Huntington District, variously paginated.

Davic, R.D., Eicher, D., and DeShon, J., 1997, 1996 Ohio water resource inventory: volume 3: Ohio's public lakes, ponds, and reservoirs: Ohio Environmental Protection Agency, Division of Surface Water, Technical Bulletin MAS/1997-10-2, variously paginated, accessed October 12, 2006, at http://www.epa.state.oh.us/dsw/ documents/96vol3.pdf

This report provides a summary of water quality of public lakes, ponds, and reservoirs throughout Ohio including Atwood Reservoir, Nimisila Reservoir, and Tappan Lake and lists those waters that are currently not meeting waterquality standards. The most common issues include very low or no dissolved oxygen and elevated concentrations of manganese and total dissolved solids. Sampling of bottom sediments revealed elevated concentrations of chromium and zinc at Atwood Reservoir and elevated chromium at Tappan Lake. Atwood Reservoir and Tappan lake also had detectable concentrations of d-BHC (lindane, an insecticide), and Nimisila Reservoir had detectable concentrations of dieldrin (another insecticide).

Dean, E.S. (compiler), 1948, Additional analyses of coals of Ohio: Ohio Department of Natural Resources Report of Investigation 4, $17 \mathrm{p}$.

DeBrosse, T.A., 1957, Coal beds of the Conemaugh formation in Ohio: Ohio Department of Natural Resources Report of Investigation $34,33 \mathrm{p}$.

DeLong, R.M., 1955, The Pittsburgh No. 8 and Redstone No. 8A coals in Ohio: Ohio Department of Natural Resources Report of Investigation 26, 49 p. 
DeLong, R.M., 1957, Coal resources of the lower part of the Allegheny formation in Ohio: Ohio Department of Natural Resources Report of Investigation 31, 43 p.

DeLong, R.M., 1965a, Geology of the Kensington quadrangle, Ohio: Ohio Department of Natural Resources, Division of Geological Survey, Report of Investigations 55, scale 1:24,000.

This is one of a series of reports on geology that is later summarized in Delong (1969). Most of the surficial bedrock is the Conemaugh Formation. The map also shows the extent of glaciation mapped by Goldthwait (1967). Silurianage salt deposits at 3,200 to 3,500 ft below land surface are specifically mentioned.

DeLong, R.M., 1965b, Geology of the Malvern quadrangle, Ohio: Ohio Department of Natural Resources, Division of Geological Survey, Report of Investigations 57, scale 1:24,000.

The Conemaugh and Allegheny Formations account for most of the surficial bedrock in the Malvern quadrangle. Much more of the surface area of the Malvern quadrangle is covered by alluvium and Wisconsinan glacial deposits than is the Kensington quadrangle of Delong (1965a). The Kensington quadrangle also contains some Illinoian glacial deposits and shows the extent of Illinoian glaciation.

DeLong, R.M., 1967, Bedrock geology of the Minerva quadrangle, Stark, Columbiana, and Carroll Counties, Ohio: Ohio Department of Natural Resources, Division of Geological Survey, Report of Investigations 65, scale 1:24,000.

DeLong, R.M., 1968, Bedrock geology of the Dellroy quadrangle, Carroll County, Ohio: Ohio Department of Natural Resources, Division of Geological Survey, Report of Investigations 68, scale 1:24,000.

Most of the surficial bedrock in the Dellroy quadrangle is the Conemaugh Formation in the uplands and the Allegheny Formation in the valleys. The Union pool is noted as a significant oil and gas source within the Berea and Cussewago Sandstones.

DeLong, R.M., 1969, Bedrock geology of the Carrollton quadrangle, Carroll County, Ohio: Ohio Department of Natural Resources, Division of Geological Survey, Report of Investigations 71, scale 1:24,000.

The report includes a stratigraphic section, map, and description of mineral resources. It also shows oil and gas wells as of 1969 and abandoned shaft or slope mines in the Middle Kittanning Coal. Most of the surficial bedrock is of the Conemaugh Formation. Oil and gas are produced from the Berea and Cussewago Sandstones, along with some natural gas from a coal bed (Kittanning?).
DeLong, R.M., 1972, Bedrock geology of the Bergholz quadrangle, Carroll and Jefferson Counties, Ohio: Ohio Department of Natural Resources Report of Investigation 87 , one sheet with text.

DeLong, R.M., 1978, Structure on the Pittsburgh (No. 8) coal in the Belmont field, Ohio: Ohio Department of Natural Resources Report of Investigation 106, two sheets.

DeLong, R.M., 1990, Bedrock geology, north of Muddy Fork and Still Fork of Sandy Creek, of the Minerva quadrangle, Ohio: Ohio Department of Natural Resources, Division of Geological Survey, Open-File Map BG-C2F1, scale 1:24,000.

DeLong, R.M., and White, G.W., 1963, Geology of Stark County: Ohio Department of Natural Resources, Division of Geological Survey, Bulletin 61, 209 p.

This is a summary of the geology of Stark County with many references to early geological explorations of the State. The report describes drainage characteristics, flow directions, and flow reversals before and through glacial periods.

Denny, G.L., 1988, Jackson Bog State Nature Preserve: Ohio Department of Natural Resources, Division of Natural Areas and Preserves, $12 \mathrm{p}$.

This is a pamphlet describing the formation of a bog, characteristics of a fen, and plant ecology and types. "...As the Wisconsinan glacier melted, a kettle lake formed in the kame moraine area near Canton. Boreal vegetation colonized the site, and fen vegetation became established on the highly saturated sand and gravel deposits between the kames. Canadian bog plants continued to grow at Jackson Bog, long after the climate changed, thanks to groundwater discharge into the bog from outwash deposits. The groundwater is highly saturated with calcium and magnesium bicarbonates, has a $\mathrm{pH}$ of 8.0 to 9.0 , temperature of 54 degrees F, and low oxygen content - similar to conditions along the edge of the glacier during the Ice Age."

Denton, G.H., 1960, Coal resources of the upper part of the Monongahela formation and the Dunkard group in Ohio: Ohio Department of Natural Resources Report of Investigation 38,50 p.

Domenico, P.A., and Schwartz, F.W., 1990, Physical and chemical hydrogeology: New York, John Wiley and Sons, 824 p.

Dow, J.W., 1962, Lower and Middle Devonian limestones in northeastern Ohio and adjacent areas: Ohio Department of Natural Resources Report of Investigation 42, 67 p.

Dumouchelle, D.H., 2006, Selected ground-water-quality data from wells in the Scenic Heights-Batdorf Road area, Wooster Township, Wayne County, Ohio: U.S. Geological Survey Open-File Report 2006-1382, 13 p. 
Dumouchelle, D.H., and Bair, E.S., 1994, Ground-water levels and directions of flow near the Industrial Excess Landfill, Uniontown, Ohio, March 1994: U.S. Geological Survey Water-Resources Investigations Report 94-4136, 17 p.

This report documents water levels in 149 wells, river stage at 13 staff gages, and water levels in 9 piezometers at sites surrounding the Industrial Excess Landfill (IEL). The regional pattern of groundwater flow generally is from east to west, but it is locally altered by groundwater mounds that reflect the hummocky terrain. The relatively small groundwater mound at the landfill causes groundwater to flow radially away from the southeastern corner of the landfill.

Dumouchelle, D.H., and Schiefer, M.C., 2002, Use of streamflow records and basin characteristics to estimate groundwater recharge rates in Ohio: Ohio Department of Natural Resources, Division of Water Bulletin 46, 45 p.

Groundwater recharge rates were estimated by use of computer programs that analyzed streamflow records. "...Basins with 20 percent or more coverage of soils with low infiltration rates tended to have recharge rates of less than 6 inches per year whereas basins with 20 percent or more coverage of soils of high infiltration rates tended to have recharge rates of 8 in yr or more." The estimated recharge rates for Sandy Creek were 9 to 10 inches per year and for Home Creek near New Philadelphia it was 6 inches per year.

Earth Action Partnership, Inc., 2006, Reifsnyder Wetland, accessed September 20, 2006, at http://www. earthactionpartnership.org/reifsnyder.htm

The Ohio Environmental Protection Agency required the City of Canton to reduce nitrate concentrations in Nimishillen Creek. As a result, the City of Canton funded a study on the construction of a series of holding ponds to form a wetland in a small park along the Middle Branch of Nimishillen Creek.

Eckstein, Y., Matyjasik, B., Matyjasik, M., and Haitjema, H.M., 2001, Dislocation of the continental ground-waterdivide induced by excessive pumping in Summit County, Ohio; 2000 annual meeting on Atmospheric, surface and subsurface hydrology and interactions: Hydrological Science and Technology, v. 17, no. 1-4, p. 119-128.

Crystal Lake experienced a substantial drop in the water table and in the lake during the years 1991-94. Mapping of the water table disclosed an expanding cone of depression centered at the wells of the Montrose Well Field of Summit County. Expansion of the cone of depression to the west resulted in dislocation of the groundwater divide between the Cuyahoga River (discharging to Lake Erie) and Tuscarawas River (a tributary to the Ohio River), "pirating" Crystal Lake from the Great Lakes drainage into the Ohio River Drainage Basin. Water levels and groundwater flow were simulated in the area of the Montrose Well Field using the MODFLOW numerical model, with average aquifer hydraulic properties obtained from interpretation of aquifer tests at the two production wells. Results of the model simulation, together with the groundwater-level surveys, indicate that Crystal Lake converted during the 10 years (1985-1994) from an effluent to an influent surface-water body. Also, the model indicates that the excessive drawdowns in the two Montrose production wells resulted in the drop of the water level below the semi-confining boundary of the till covering the kame gravel aquifer, changing the aquifer conditions from a semi-confined to unconfined.

Edelen, G.W. Jr., Ruggles, F.H., Jr., and Cross, W.P., 1962a, Floods at Barberton, Ohio: U.S. Geological Survey Hydrologic Investigations Atlas HA-49, scale 1:24,000.

The topographic map shows the area inundated at Barberton, Ohio, by the Tuscarawas River and Wolf Creek during the flood of January 22, 1959. This was the highest flood level since March 1913 on the Tuscarawas River and Wolf Creek at Barberton.

Edelen, G.W., Jr., Somers, W.P., and Cross, W.P., 1962b, Floods at Canton (Stark County), Ohio: U. S. Geological Survey Hydrologic Investigations Atlas HA-50, scale 1:24,000.

The atlas shows area inundated by the Middle Branch and East Branch Nimishillen Creek during the flood of January 21-22, 1959. This was the highest flood level on these rivers since at least 1886. A flood in February 1959 inundated almost the same area.

Engelke, M.J., Jr., and Roth, D.K., 1981, Hydrology of Area 7, Eastern Coal Province, Ohio: U.S. Geological Survey Open-File Report 81-815, 60 p.

Chemical, physical, biological, and streamflow data were collected at 138 sites in eastern Ohio. Data from currently mined, reclaimed, and abandoned mine and unmined areas were compared. “...Low $\mathrm{pH}$, high specific conductance, high concentrations of iron, sulfate, and manganese, increased sediment yields, discoloration of streambeds, limited aquatic vegetation and animal life typify streams draining areas with abandoned mines. In areas where land has been reclaimed, the environmental stress is expected to be temporary."

Eshler, L.M., 1988, Hydrogeological analysis of Sharon Township, Medina County, Ohio: Akron, Ohio, University of Akron, M.S. thesis, p. 92

This thesis contains qualitative and quantitative information about the water quality and hydrologic properties of individual aquifers in Sharon Township, Medina County. The shallow bedrock is described as a highly fractured interconnected aquifer system. The bedrock surface and groundwater flow closely parallel surface topography. Water quality is calcium-bicarbonate type. 
Espinoza, M., 2005, When all streams come together: Wooster, Ohio, Ohio Agricultural Research and Development Center News, accessed October 18, 2006, at http://www.oardc. ohio-state.edu/story.php? id $=3161$

This article summarizes work related to 319 grants going on in the Sugar Creek watershed. The overall goal is improving quality and awareness of headwaters of Sugar Creek. The article also describes the Sugar Creek Headwaters Project, a grassroots effort in Wayne and Holmes Counties led by Richard Moore at Ohio State University.

Fenneman, N.M., 1938, Physiography of the Eastern United States: New York, McGraw-Hill Publishing Company, $714 \mathrm{p}$.

Forsyth, J.L., 1961, Dating Ohio glaciers: Ohio Department of Natural Resources Information Circular 30, 9 p.

Foulk, C.W., 1925, Industrial water supplies of Ohio: Ohio Department of Natural Resources Bulletin 29, 406 p.

Francisco, B.H., and Shakoor, A., 1997, A geotechnical evaluation of the potential use of selected waste materials for lime spoil stabilization [abs]: Annual Meeting-Association of Engineering Geologists, v. 40, p. 99.

Francy, D.S., Jones, A.L., Myers, D.N., Rowe, G.L., Eberle, C.M. and Sarver, K.M., 1998, Quality assurance/qualitycontrol manual for collection and analysis of water-quality data in the Ohio District: U.S. Geological Survey WaterResources Investigations Report 98-4057, 71 p.

Francy, D.S., Myers, D.N, and Helsel, D.R., 2000, Microbiological monitoring for the U.S. Geological Survey National Water-Quality Assessment Program: U.S. Geological Survey Water-Resources Investigations Report 00-4018, 31 p.

Freeze, R.A., and Cherry, J.A., 1979, Groundwater: Englewood Cliffs, N.J., Prentice-Hall, Inc., 604 p.

Fuller, J.O., 1955, Source of Sharon conglomerate of northeastern Ohio: Ohio Department of Natural Resources Report of Investigation 23, 17 p. (Reprinted from Geological Society of America Bulletin, 1955, v. 66, p. 159-S175.)

Gannett Fleming, I., 2000, Acid mine drainage abatement and treatment plan for the Huff Run Watershed: Huff Run Watershed Restoration Partnership, 52 p., accessed on December 12, 2006, at http://www.huffrun.org/amdat.pdf

This acid mine drainage abatement and treatment (AMDAT) plan for Huff Run describes current conditions and the potential for restoration of the watershed, establishes restoration goals, defines and prioritizes projects for funding, and recommends future monitoring programs. Current aquatic life conditions are summarized as being “... significantly impaired in the lower five reaches as a result of the episodic $\mathrm{pH}$ excursions during low flow conditions, and an increase in metal loading. Consequently, it is recommended that restoration efforts be focused to address these trends. With the top-down approach, projects within a watershed are implemented in an upstream to downstream order, extending the benefit over the greatest length of stream being restored."

Garvey, J.T., 1988, The hydrogeology of eastern Franklin and western Green Townships, Summit County, Ohio: Akron, Ohio, University of Akron, M.S. thesis, 97 p.

This thesis describes groundwater availability and quality in Summit County. The author did a gravity survey that supports previous interpretations that the valley floor tilts to the north. Specific capacity of the glacial drift was estimated at $1.7 \mathrm{gal} / \mathrm{min} / \mathrm{ft}$, hydraulic conductivity was $390 \mathrm{gal} / \mathrm{d} / \mathrm{ft}^{2}$ and transmissivity was $37,500 \mathrm{gal} / \mathrm{d} / \mathrm{ft}$. Water quality is calcium bicarbonate type. Locally, there were issues with elevated nitrate concentrations of as much as $21 \mathrm{mg} / \mathrm{L}$ (milligrams per liter).

Gilliom, R.J., Barbash, J.E., Crawford, C.G, Hamilton, P.A., Martin, J.D., Nakagaki, N., Nowell, L.H., Scott, J.C., Stackelberg, P.E., Thelin, G.P., and Wolock, D.M., 2006, The quality of our Nation's waters - pesticides in the Nation's streams and ground water, 1992-2001: U.S. Geological Survey Circular 1291, 172 p.

Glugla, G. and Tiemer, K., 1971, Ein verbessertes Verfahren zur Berechnung der Grundwasserneubildung (An improved method for the calculation of groundwater recharge, in German): Wasserwirtsch. u. Wassertech, v. 20, no. 10, p. 349-353 (reference citation obtained from Bonta and Muller, 1999).

Golden, P.D., Jones, W.A., Brown, L.C., and Ricker, K.T., undated a, Coshocton County groundwater resources: Ohio State University Extension Fact Sheet AEX-490.16, accessed November 20, 2006, at http://ohioline.osu.edu/ aex-fact/0490_16.html

This is an overview of Coshocton County's groundwater resources, including definitions of aquifer and well yield. On a generalized map of well yields, Ohio Department of Natural Resources observation wells and chemical analysis sites are shown. Nitrate, high hardness, and elevated iron concentrations are present in water in the county.

Golden, P.D., Ricker, K.T., and Brown, L.C., undated b, Water resources of Coshocton County: Ohio State University Extension Fact Sheet AEX-480.16, accessed November 20, 2006, at http://ohioline.osu.edu/aex-fact/0480_16.html

This is an overview of water resources for Coshocton County, including precipitation, groundwater, surface water, water use, and water quality. Average rainfall for the county is 39 inches per year, providing 10 inches of runoff to streams and lakes. About 6.1 inches have the potential to recharge aquifers. Land use is 50 percent farmland. 
Goldthwait, R.P., White, G.W., and Forsyth, J.L., 1967, Glacial map of Ohio: U.S. Geological Survey Miscellaneous Geologic Investigations I-316 rev, scale 1:500,000.

Gordon, G., 1978, User's guide to the Ohio Capability Analysis Program: Columbus, Ohio, Ohio Department of Natural Resources Division of Water, 159 p.

This guide gives the rationale and examples of the Ohio Capability Analysis Program that provided information for decisionmakers to analyze resource data in terms of the data's ability to support various land uses.

Granchi, J.A., 1958, Coal resources of the Pottsville formation: Ohio Department of Natural Resources Report of Investigation $36,53 \mathrm{p}$.

Gray, J.D., Struble, R.A., Carlton, R.W., Hodges, D.A., Honeycutt, F.M., Kingsbury, R.H., Knapp, N.F., Majchszak, F.L., Stith, D.A. (Eds.), 1982, An integrated study of the Devonian-age black shales in Eastern Ohio: Ohio Geological Survey Report to the U.S. Department of Energy, DOE/ ET/12131-1399, p. 863-900.

Groenewold, G.H., 1974, Hydrogeologic and other considerations related to the selection of sanitary-landfill sites in Ohio: Ohio Department of Natural Resources, Division of Geological Survey, Information Circular 41, 15 p.

This report provides information needed for the selection of potential land fill sites. " ....Flat to gently sloping upland areas are generally better suited than lowlands and steep slopes. Dry fine-textured materials are the most effective natural filtering agents. Saturated coarse-textured materials and fractured rocks are very ineffective as filtering agents. However, depth to the water table is generally not as important as the texture of the materials. Extremely fine-textured materials may act as impermeable membranes and eliminate all downward movement of leachate; under such conditions surface seeps may form around the landfill. Proper selection of cover materials will decrease infiltration into the landfill as well as help to eliminate the lateral migration of gases from the site."

Haefner, R.J., 2002, Water quality and geochemical modeling of water at an abandoned coal mine reclaimed with coal combustion by-products: U.S. Geological Survey WaterResources Investigations Report 02-4216, 28 p.

A 7-acre abandoned coal mine was reclaimed with pressurized fluidized-bed combustion byproducts during 1994. Water quality at the mine site was monitored after the reclamation to evaluate the fate and transport of undesirable elements derived from the leachate, such as sulfate, arsenic, and boron. Even though elevated concentrations of sulfate and boron were found in the shallow unsaturated zone, little, if any, leachate was detected in groundwater or surface water leaving the site.
Hambrook, J.A., Armitage, B.J., and Vis, M., 1999, Algal and macroinvertebrate assemblages of selected Ohio springs: Ohio Biological Survey Notes, v. 2, p. 1-24.

This is a qualitative study of the algal flora, macroinvertebrate fauna, and water quality of 10 Ohio springs, conducted from July through September 1996. Springs in Medina (Styx River) and Summit County (Sand Run and Gorge Metropark) are included in this report.

Harker, D.H., 1943a, Ohio’s water supply: Columbus, Ohio, Ohio Water Supply Board, 11 p.

Harker, D.H., 1943b, Report on Ohio water table survey, June 15, 1943: Columbus, Ohio, Ohio Water Supply Board, 52 p.

The report documents the earliest water-table survey by county agricultural agents of 32 of the 88 counties of Ohio. Data relating to the Tuscarawas River Basin are available for Medina, Holmes, Tuscarawas, Guernsey, and Belmont Counties.

Harker, D.H., 1943c, Report on Ohio water table survey, December 1, 1943: Columbus, Ohio, Ohio Water Supply Board, 19 p.

This report describes the continuation and expansion of the program described in Harker (1943a), with 49 counties cooperating in the program. "...[During the 1930's] The Midwest experienced a series of drouth [sic] years such as it had not known in the twentieth century. Only since 1941 have rainfall figures been decidedly favorable. Only now is Ohio beginning to recover from a deficiency of 26 inches piled up during the years 1930 to 1941 inclusive. However, there were many extended periods of drouth during the 1800 's when Ohio was still in forest timber. One of particular interest was in 1824 and 1825 when, according to records of Ohio's canal commissioners, the groundwater was so low that streams did not furnish enough water for operation of canal systems."

Harker, D.H., 1944a, Post-war planning for water supply in Ohio: Columbus, Ohio, Ohio Water Supply Board, 17 p.

This report to the Water Supply Board describes needs and recommendations for expansion of water supplies. "...Collection and study of data are essential. They constitute the proper approach to the solution of any problem. But there comes a time when collection and study of available information must give way, if only temporarily, to the development of a plan of solution. It is at this point that the Ohio Water Supply Board now finds itself. A plan for the remedying of Ohio's water supply ills is in the making. It will be comprehensive. It will be definite. It will be practical. It will be brought to the legislature of our state in the next regular session in January, 1945."

Specific descriptions are provided of the water situation in Canton and Akron. Canton requires more water for industrial supply. "...At the present time Canton industries are 
doing very well, because the situation for groundwater in the Canton vicinity is truly a remarkable one. However, it is possible that a serious industrial water problem may arise soon if the city for its domestic use does not find new groundwater fields or develop a new surface water source."

"...Akron is poorly situated for ground water except where deep gravels occur. The City of Akron has long used surface water from reservoirs constructed for the purpose. Lake Rockwell, the present source is reported to be most adequate. It is not hindered by the usual siltation problem that afflicts many artificial reservoirs and is said to have lost relatively little capacity."

The Ohio Water Supply Board instituted a water-table survey with nearly 1,000 observers in almost 60 counties. Based on these data... "We have reason to doubt the statement that the water table is falling "a foot a year." During 1943, it fell 3.17 feet, but during good rainfall years it can be expected to rise a like amount or even more. There are alarmists who make it appear that the general trend of the water table is continually down because of the cutting of forests, intensive farming and land drainage. We believe that this is not the case and we are conducting the Ohio Water table Survey now for last year, not for this year but for always with the intention of showing definitely what the water table is doing year after year.

It is believed that the ground and surface water studies should never be discontinued. It is as essential for the state to know how the water table compares from year to year as it is for it to know how its rainfall, temperature, and streamflow varies. This work should not only be continued but should be amplified and along with it there should be a general amplification of the state geological survey which now spends annually about $\$ 15,000 . ”$

Harker, D.H., 1944b, Report to Ohio Water Supply Board, Columbus, Ohio, on water supply in Summit County: Columbus, Ohio, Ohio Water Supply Board, 81 p.

This report provides a summary of the water-supply situation in Summit County along with population numbers for Akron from 1860 to 1940. As stated in the report, the water-supply issues are as follows: “...1. shales cause problems with farm and domestic supplies in western halves of Boston and Northampton Townships, 2. most of the buried valleys in the Akron area are filled with fine sand, silt, and clay, 3. Cuyahoga Falls, Lakemore, Hudson, and Twinsburg have ground water supplies that are adequate and can be expanded, 4. Barberton's water supply is scarcely more than adequate because of the war, 5. Akron's domestic supply is among the most adequate in Ohio, 6. Some room for improvement in 3 surface water supplies for Akron and Barberton."

Harker, D.H., and Bernhagen, R.J., 1943a, Report on water for industry in Ohio: Investigation and report: Columbus, Ohio, Ohio Water Supply Board, 88 p.
This is a water-use report that describes surpluses in water quantity that may be available for industrial utilization.

The report includes tables of average daily consumption of major cities, costs of water, total hardness, and $\mathrm{pH}$. Groundwater supplies are listed by regions..." The unconsolidated glacial deposits in the Muskingum Valley (Dresden to Dover) afford one of the finest ground water reserves in the State. Supplies as great as 5 million gallons per day can be developed and it is possible that, following test drilling and pumping tests, even larger supplies can be developed without any detrimental effect to the existing water supplies. Within these limits the Tuscarawas Valley from Zoar to Massillon is known to be underlain with a relatively great thickness of glacial outwash material."

Harker, D.H., and Bernhagen, R.J., 1943b, Report on water supply in Medina County: Field investigation and report: Columbus, Ohio, Ohio Water Supply Board, 30 p.

Medina County was divided into four zones on the basis of groundwater availability. The map included in this report shows characteristics of water-bearing units and results of water analyses for supply wells in Wadsworth finished in the Sharon Sandstone and in the Chippewa Lake area finished in sand and gravel, along with a hydrograph for 1935 to 1942 . Stream pollution and intrusion of saltwater and oil into water-bearing units from activities in the Chatham oil field area are described here.

Harker, D.H., and Bernhagen, R.J., 1943c, Report to Ohio Water Supply Board, Columbus, Ohio on water supply in Stark county: field investigation and report: Columbus, Ohio, Ohio Water Supply Board, 67 p.

This is a report prepared for the City of Canton. The major conclusions of this work are: (1) farm and domestic water supplies are readily obtained in all parts of Stark County from gravel, shale, and sandstone wells; (2) Canton probably must eventually go to a surface-water supply in Sandy Creek; (3) Massillon has no water-supply problem; (4) Alliance has a very real water-supply problem; (5) North Canton has sufficient present supply from rock wells; (6) Louisville, East Canton, and Canal Fulton have rock water supplies which appear ample; and (7) Minerva, Navarre, Brewster, Waynesburg, Beach City, Magnolia, and Hills and Dales use gravel wells and have ample supplies. (8) It is believed that any small community in Stark County can readily develop a supply from groundwater sources.

Harrell, J.A., McKenna, J.P., and Kumar, A., 1993, Geological controls on indoor radon in Ohio: Ohio Department of Natural Resources Report of Investigation 144, 36 p., 10 figs., 1 table.

Harstine, L.J., 1991, Hydrologic Atlas for Ohio; average annual precipitation, temperature, streamflow, and water loss for 50-year period, 1931-1980: Ohio Department of Natural Resources Division of Water, Water Inven- 


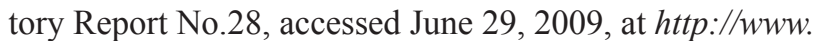
dnr.state.oh.us/water/pubs/hydatlas/tabid/4187/Default. aspx\#anchor 1703518

Heaton, K.P., 1982, The hydrogeology of the City of Stow and Hudson Township, Summit County, Ohio: Kent, Ohio, unpublished M.S. thesis Kent State University Department of Geology, 251 p.

Heaton, T.H.E., 1981, Dissolved gases: Some application to groundwater research: Transactions of the Geological Society of South Africa: v. 84, p. 91-97.

Heaton, T.H.E, and Vogel, J.C., 1981, "Excess air" in groundwater: Journal of Hydrology, v. 50, p. 201-216.

Heaton, T.H.E., Talma, A.S., and Vogel, J.C., 1983, Origin and history of nitrate in confined groundwater in the Western Kalahari: Journal of Hydrology, v. 62, p. 243-262.

Heiskanen, W.A., and Uotila, U.A., 1956, Gravity survey of the State of Ohio: Ohio Department of Natural Resources Report of Investigation 30, 34 p.

Heit, M., 1985, The relationship of a coal fired power plant to the levels of polycyclic aromatic hydrocarbons (PAH) in the sediment of Cayuga Lake: Water Air Soil Pollution, v. 24, p. 41.

Hem, J.D., 1985, Study and interpretation of the chemical characteristics of natural water: U.S. Geological Survey Water-Supply Paper 2254, 263 p.

Heritage Pursuit, 2009, History of Tuscarawas County, accessed January 28, 2009, at $h t t p: / / w w w$.heritagepursuit. com/Tuscarawas/TuscarawasChapI.htm

Himes, B.T., 1982, Outwash terraces of the Kokosing and Walhonding river valleys, Knox and Coshocton counties, Ohio: unpublished M.S. thesis, Columbus, Ohio, Ohio State University, 63 p.

Hogan, M., Boone, K.M., and Brown, L.C., undated a, Water resources of Carroll, Harrison and Jefferson Counties: Ohio State University Extension Fact Sheet AEX-480.89, accessed September 21, 2006, at http://ohioline.osu.edu/ aex-fact/0480_89.html

This fact sheet provides an overview of water resources for Carroll, Harrison, and Jefferson Counties, including summary information on precipitation, groundwater, and surface water, water use, and water quality. Average rainfall for the three-county area is 39 inches per year, providing 10 inches of runoff to streams and lakes. About 6 inches of rainfall has the potential to recharge aquifers. Land use is 96 to 98 percent rural with 31 to 46 percent farmland. Nitrate in groundwater is an issue.

Hogan, M., Raab, J.M., and Brown, L.C., undated b, Groundwater resources of Carroll, Harrison and Jefferson Counties:
Ohio State University Extension Fact Sheet AEX-490.89, accessed September 21, 2006, at http://ohioline.osu.edu/ aex-fact/0490_89.html

This fact sheet gives an overview of Carroll, Harrison, and Jefferson County's groundwater resources, including definitions of aquifer and well yield. The fact sheet includes a generalized map of well yields, Ohio Department of Natural Resources observation wells, and chemical analysis sites. The sand and gravel deposits along the Ohio River in Jefferson County and along the many stream and creek valleys throughout all three counties have the potential to provide water adequate for domestic and agricultural uses and many municipal uses. Chemical analysis for major anions and cations show hard water and elevated iron concentrations.

Hoover, K.V., 1960, Devonian-Mississippian shale sequence in Ohio: Ohio Department of Natural Resources Information Circular 27, $154 \mathrm{p}$.

Horton, A.H., and Jackson, H.J., 1913, The Ohio valley flood of March-April, 1913, including comparisons with some earlier floods: U. S. Geological Survey Water-Supply Paper 334, $96 \mathrm{p}$.

Huff Run Watershed Restoration Project, 2006a, Fish studies, accessed September 18, 2006, at http://www.huffrun.org/ fish.html.

Three segments of Huff Run were sampled for fish before 2002. As the stream flows west, it travels from undisturbed, original conditions into areas where coal has been removed from surface and underground mines. The results illustrate diverse fish communities above the mining sites and only pollution-tolerant fish species in the lower course of the stream. Fish populations were sampled again in 2003 and 2005 , and larger numbers of fish were collected downstream than during the earlier studies indicating that "...the stream health is getting better."

Huff Run Watershed Restoration Project, 2006b, Macroinvertebrate studies, accessed September 18, 2006, at http://www. huffrun.org/macro.html.

This Web page shows results of a macroinvertebrate study conducted by Mount Union College in summer 2004.

Results are difficult to interpret because data were lost due to flooding. Macroinvertebrate conditions near Mineral City are not as good as those upstream. The Web site also has a link to a 2002 macroinvertebrate study by Maureen March.

Huff Run Watershed Restoration Project, 2006c, Water quality of Huff Run, accessed September 18, 2006, at http://www. huffrun.org/wq.html

The Huff Run watershed drains $14.1 \mathrm{mi}^{2}$ in Tuscarawas and Carroll Counties, and the stream is a tributary to Conotton Creek. "...Huff Run is a very polluted stream. The largest problem is acid mine drainage. Secondary issues are broken 
vegetative buffers, illegal dumping, sewage influences, oil and gas development, and agricultural impacts." pH of streamwater is low and acidity is high, resulting in high concentrations of iron, aluminum, manganese. These waterquality problems are caused by drainage from abandoned coal mines "and other poor mining practices predating mining laws and regulations."

The Web page contains additional links to the 2005 Watershed Plan, the Huff Run Acid Mine Drainage Abatement and Treatment Plan, fish studies, and macroinvertebrate studies.

Hull, D.N., 1980, Sand and gravel resources of Portage County, Ohio: Ohio Department of Natural Resources, Division of Geological Survey, Report of Investigations 114, scale 1:63,360.

The map shows the extent of kame deposits, eskers, and alluvium in Portage County. Western Portage County includes part of the largest kame complex in Ohio, between the Killbuck and Grand River glacial lobes. The map also provides estimates of available sand and gravel resources (in tons) by township, sieve analyses, pebble counts, stratigraphic sections from several water-well logs, and three measured sections from the Tuscarawas River Basin.

Hull, D.N., 1984, Geologic evaluation of land areas in Portage County, Ohio, for solid-waste disposal: Ohio Department of Natural Resources, Division of Geological Survey, Report of Investigations 126, scale 1:63,360.

Although much of Portage County may be suitable for siting a landfill, the southwest corner of the county, which drains into the Tuscarawas Basin, is "generally unsuitable" for solid-waste disposal due to (1) the presence of highly permeable sand and gravel which would likely allow groundwater contamination by refuse leachate, and (2) areas of alluvial material in floodplains and bogs which have typically high water tables, and (or) which flood frequently.

Hull, D.N., 1987, Surficial materials of Portage County, Ohio: Ohio Department of Natural Resources, Division of Geological Survey, Report of Investigations 138, scale 1:63:360.

This report provides a description of the character of materials within the upper $20 \mathrm{ft}$ of land surface. Surficial material in the area of the Tuscarawas Basin is Kent Till. The dominant material at the surface is sand and gravel with lenses of silty, clayey till, but also may include alluvium over sand and gravel.

Hull, D.N., comp., 1990, Generalized column of bedrock units in Ohio: Ohio Department of Natural Resources, Division of Geological Survey [oversize sheet]. (Revised by G.E. Larson (2000) and E.R. Slucher (2004).)

Hutson, S.S., Barber, N.L., Kenny, J.F., Linsey, K.S., Lumia, D.S., and Maupin, M.A., 2004, Estimated use of water in the United States in 2000: U.S. Geological Survey Circular $1268,46 \mathrm{p}$.

Hyde, J.E., 1953, Mississippian formations of central and southern Ohio: Ohio Department of Natural Resources Bulletin $51,355 \mathrm{p}$.

Hyland, S.M., 1982, Benthic macroinvertebrates as indices of water quality in the upper Tuscarawas River: Akron, Ohio, University of Akron, M.S. thesis, p.76

Iqbal, M.Z., 1990, Groundwater resources of Chippewa Creek Valley in Wayne and Medina Counties, Ohio: Akron, Ohio, University of Akron, M.S. thesis, p.104

Ivahnenko, T., and Barbash, J.E., 2004, Chloroform in the hydrologic system-Sources, transport, fate, occurrence, and effects on human health and aquatic organisms: U.S. Geological Survey Scientific Investigations Report 2004-5137, $34 \mathrm{p}$.

Jackson, J.L., Bauder, J.R., Hardy, J., and Kennedy, M., 1989, Field studies: Hardy Road Landfill and Industrial Excess Landfill, a Superfund site: Ohio Journal of Science, v. 89, no. 3, p. 45-S55.

The site was an active sand and gravel pit before 1955; waste disposal started in 1959. Sand and gravel deposits are underlain by lacustrine silts and clays. Geologic conditions contributed to off-site movement of methane in 1984, resulting in destruction by fire of a private dwelling. Gas migration down dip in gravels caused the explosion. In $1989,600,000$ cubic feet of landfill gas were collected and flared every day at Hardy Road. The major concern at the Industrial Excess landfill at Uniontown was groundwater contamination. Till at depth may account for the relatively low level of contamination at the site.

Janssens, A., 1973, Stratigraphy of the Cambrian and Lower Ordovician rocks in Ohio: Ohio Department of Natural Resources Bulletin 64, 197 p.

Janssens, A., 1977, Silurian rocks in the subsurface of northwestern Ohio: Ohio Department of Natural Resources Report of Investigation 100, 96 p.

Janssens, A., and de Witt, W. Jr., 1976, Potential natural gas resources in the Devonian shales in Ohio: Ohio Department of Natural Resources Geological Note 3, 12 p.

Johnson, T.W., 1986, Muskingum River Task Force: Columbus Ohio, Muskingum River Task Force, 27 p.

Jones, H.P., Henry, T.B., and Williams, L.G., 1958, Water improvements report for Wooster Ohio: Toledo, Ohio, Jones, Henry, and Williams Engineers, 201 p.

Jones, M.W., 1961, Construction and operation of a chloride holding basin: Proc.16th Industrial Waste Conference, Purdue University Engineering Extension Service No.109, p. 186-S192. 
The Barberton, Ohio, plant of the Pittsburgh Plate Glass Co. manufactured soda ash. The waste waters, which contained high concentrations of chloride, were formerly discharged continuously to the Tuscarawas River after sedimentation in a lagoon. In view of the increasing pollution of the Ohio river with chloride, it was decided to construct a large holding lagoon in which the wastewaters could be stored during periods of low river flow and discharged at controlled rates during periods of high flow; the rate of discharge was proportioned to river flow so that the concentration of chloride in the river water at a control point at Clinton, Ohio, did not exceed a selected maximum value. Initial operation of the holding lagoon was satisfactory.

Jost, D.J., 1994, Hydrogeology and pollution potential of aquifers, Doylestown, Wayne County, Ohio: Akron, Ohio, University of Akron, M.S. thesis, 177 p.

This thesis provides background information for a wellhead protection plan for Doylestown in northeastern Wayne County. To examine the characteristics of the contributing recharge areas to the wellfield, the calculated fixed radius method was used along with the DRASTIC mapping system. The wellfield is underlain by Sharon Sandstone and the Rittman and Armstrong Siltstones. The average transmissivity of bedrock is $35,000 \mathrm{gal} / \mathrm{d} / \mathrm{ft}$. The hydraulic conductivity of is $10^{-4}$ to $10^{-3} \mathrm{~cm} / \mathrm{sec}$ (centimeters per second) or 2.1 to $21 \mathrm{gal} / \mathrm{d} / \mathrm{ft}^{2}$. Hydraulic conductivity of the underlying Cuyahoga group is $10^{-6}$ to $10^{-4} \mathrm{~cm} / \mathrm{sec}$ or 0.21 to $2.1 \mathrm{gal} / \mathrm{d} / \mathrm{ft}^{2}$.

Kaser, P., 1960, Report on proposed City of Canton water-supply development along Sugar Creek in Tuscarawas County: Columbus, Ohio, Ohio Water Commission, 17 p.

Canton has used groundwater as a sole source of water supply since 1898 . Production in 1960 was at 18 to $25 \mathrm{Mgal} / \mathrm{d}$ (million gallons per day). Future supplies of up to $20 \mathrm{Mgal} / \mathrm{d}$ may be obtained from sand and gravels along Sugar Creek (the report contains a thorough description of the geology underlying Sugar Creek). Tests of the aquifer underlying Sugar Creek established that the source of water or recharge is Sugar Creek itself. A recommendation was made to allow additional withdrawals with the stipulation that hydrologic observation be carried out, including installation of monitoring wells at the wellfield, at Strasburg, and at Dover, and to install another streamgage at Strasburg.

Kazman, R.G., 1949, The utilization of induced stream infiltration and natural aquifer storage at Canton, Ohio: Economic Geology, v. 44.

The Ranney Company recharged the lower aquifer by use of Ranney well inductions from the upper aquifer. The two aquifers are separated by a clay layer.

Kelly, T.D., and Matos, G.R., with major contributions provided by Buckingham, D.A., DiFrancesco, C.A., Porter,
K.E., and USGS mineral commodity specialists, 2009, Historical statistics for mineral and material commodities in the United States: U.S. Geological Survey Data Series 140, version 3.0, accessed February 15, 2009, at http://minerals. usgs.gov/ds/2005/140/\#ref

Kendall, C. and McDonnell, J. J., (eds.), 1998, Isotope tracers in catchment hydrology: Amsterdam, Elsevier Science B.V., p. $51-86$.

Kent State University Museum, 2008, Uncommon clay, accessed January 18, 2008, at http://dept.kent.edu/museum/ exhibit/pottery/pottery.html

Kerschner, D.R., 1980, The hydrogeology of Green and Springfield Townships, Summit County: Kent, Ohio, unpublished M.S. thesis, Kent State University Department of Geology, 148 p.

Khourey, C.J., 1981, The source and transport of arsenic in northeastern Ohio groundwaters: Cleveland, Ohio, Case Western Reserve University, M.S. thesis, 84 p.

Kleski Environmental Consulting, 2001, Huff Run Watershed Plan: Huff Run Watershed Restoration Partnership, 71 p., accessed December 12, 2006, at http://www.huffrun.org/ watershed_plan.pdf

This report describes a watershed plan for Huff Run. The Huff Run Watershed covers about 14.7 square miles and enters Conotton Creek. Land use in watershed was 43 percent forested, 29 percent mining, 15.4 percent agricultural, 3.6 percent urban residential, and 8 percent other. Acid mine drainage is the primary contamination concern.

Knapp, N.F., 1977, Trace elements in Ohio coals: Ohio Department of Natural Resources Report of Investigation $103,12 \mathrm{p}$.

Koltun, G.F., 1999, Floods of June 28-29, 1998, in Ohio: U.S. Geological Survey Water-Resources Investigations Report 99-4192, $22 \mathrm{p}$.

During a 96-hour period, 10 inches or more of rain fell on parts of Ohio. Twenty-three counties were declared disaster areas, and 12 fatalities occurred. City of Uhrichsville in Tuscarawas County on Stillwater Creek was hit extraordinarily hard. The report also includes damage estimates for each county.

Koltun, G.F., 2003, Techniques for estimating flood-peak discharges of rural, unregulated streams in Ohio ( $2 \mathrm{~d} \mathrm{ed}$.): U.S. Geological Survey Water-Resources Investigations Report 03-4164, $75 \mathrm{p}$.

This report describes development of a series of equations used to estimate flood discharges at ungaged sites and based on data collected at streamgages. Standard error of prediction is about 40 percent. 
Koltun, G.F., Kula, S.P., and Puskas, B.M., 2006, A streamflow statistics (StreamStats) Web application for Ohio: U.S. Geological Survey Scientific Investigations Report 2006-5312, 62 p.

Koltun, G.F., and Roberts, J.W., 1990, Techniques for estimating flood-peak discharges of rural, unregulated streams in Ohio: U.S. Geological Survey Water-Resources Investigations Report 89-4126, 68 p.

This report describes development of multiple regression equations to estimate flood discharges at ungaged sites using data from gaged sites. First edition of subsequent report by Koltun (2003).

Koltun, G.F., and Sherwood, J.M., 1998, Factors related to the joint probability of flooding on paired streams: U.S. Geological Survey Water-Resources Investigations Report 98-4238, 32 p.

This report examines probability of flooding in a stream correlated to another stream. Sandy Creek, Middle Branch Nimishillen Creek, Nimishillen Creek, and Home Creek were among the streams used for this analysis.

Kraatz, W.C., 1941, Quantitative plankton studies of Turkeyfoot Lake, near Akron, Ohio: Ohio Journal of Science, v. 41, p. 1-22.

At the time of publication of this paper, Nimisila Reservoir was in the process of filling. The report includes seasonal and vertical distributions of plankton and water-quality data including temperature, dissolved oxygen, carbon dioxide, and $\mathrm{pH}$.

Kunze, A.E., and Sroka, B.N., 2004, Effects of highway deicing chemicals on shallow unconsolidated aquifers in OhioFinal Report: U.S. Geological Survey Scientific Investigations Report 2004-5150, 187 p.

Lamborn, R.E., 1930, Geology of Jefferson County: Ohio Department of Natural Resources Bulletin 35, 304 p.

Lamborn, R.E., 1942, The coal beds of western Carroll County and the coal beds in southeastern Mahoning County: Ohio Department of Natural Resources, Division of Geological Survey, Bulletin 43, 33 p.

Lamborn, R.E., 1945, Recent information on the Maxville limestone: Ohio Department of Natural Resources Information Circular 3, $18 \mathrm{p}$.

Lamborn, R.E., 1951, Limestones of eastern Ohio: Ohio Department of Natural Resources Bulletin 49, 377 p.

Lamborn, R.E., 1952, Additional analyses of brines from Ohio: Ohio Department of Natural Resources Report of Investigation $11,56 \mathrm{p}$.
Lamborn, R.E., 1954, Geology of Coshocton County: Ohio Department of Natural Resources, Division of Geological Survey, Bulletin 53, 245 p.

This report presents an analysis of the physiography, drainage, and glacial and bedrock geology of Coshocton County. Coshocton County was little affected by the direct action of the glaciers during Pleistocene time; however, valleys were filled with substantial amounts of sediment derived from glacial lakes and meltwater. Extreme western Coshocton County (outside of Tuscarawas drainage) includes Illinoianage till. The report provides detailed descriptions of cores and geologic sections on a township by township basis.

Lamborn, R.E., 1956, Geology of Tuscarawas County: Ohio Department of Natural Resources, Division of Geological Survey, Bulletin 55, 269 p.

This report presents an analysis of the physiography, drainage, and glacial and bedrock geology of Tuscarawas County. The report describes flow patterns of major rivers before, during, and after glaciation. Prior to glaciation, streams flowed to the north along what is called the Dover River. The report provides detailed descriptions of cores and geologic sections on a township by township basis.

Lamborn, R.E., Austin, C.R., and Schaaf, D., 1938, Shales and surface clays of Ohio: Ohio Department of Natural Resources Bulletin 39, 281 p.

Larsen, G.E., 2000, Generalized column of bedrock units in Ohio: Ohio Department of Natural Resources, Division of Geological Survey [oversize sheet].

Leberfinger, J.L., 1995, Geophysical characterization of the Muskingum River glacial outwash aquifer near Conesville, Ohio: Toledo, Ohio, University of Toledo, M.S. thesis, $170 \mathrm{p}$.

Several geophysical methods (gravity, seismic refraction, and resistivity) were utilized during this investigation to obtain information pertaining to bedrock depth and the thickness and lateral extent of the water-bearing materials in the buried valley aquifer.

Lindsey, B.D., Phillips, S.W., Donnelly, C.A., Speiran, G.K., Plummer, L.N., Böhlke, J.K., Focazio, M.J., Burton, W.C., and Busenberg, Eurybiades, 2003, Residence times and nitrate transport in ground water discharging to streams in the Chesapeake Bay Watershed: U.S. Geological Survey Water-Resources Investigations Report 03-4035, 201 p.

Little, C., Thompson, P.L., N'Jie, N., and Brown, L.C., undated, Water resources of Guernsey County: Ohio State University Extension Fact Sheet AEX-480.30-98, accessed November 20, 2006, at http://ohioline.osu.edu/aexfact/0480_30.html

This is an overview of water resources for Guernsey County, including precipitation, groundwater, surface water, 
water use, and water quality. Average rainfall for the county is 39.4 inches per year providing 10.2 inches of runoff to streams and lakes. About 6.3 inches of rainfall has the potential to recharge aquifers. Land use is 41 percent farmland. Water-quality monitoring indicates that all or parts of Guernsey County streams are impaired by nonpoint-source contamination, including West Fork Duck, Little Stillwater Creek, and Wills Creek.

Mahler, B.J., Van Metre, O.C., Bashara, T.J., Wilson, J.T., and Johns, D.A., 2005: Parking lot sealcoat: an unrecognized source of polycyclic aromatic hydrocarbons: Environmental Science and Technology, v. 39, no. 15, p. 5560-5566.

Majchszak, L., 1984, Geology and formation-water quality of the "Big Injun" and "Maxton" sandstones in Coshocton, Guernsey, Muskingum, and southern Tuscarawas Counties, Ohio: Ohio Department of Natural Resources, Division of Geological Survey, Report of Investigations 124, 36 p.

The "Big Injun" is the western sandstone body traced to the outcrop of the Black Hand Sandstone Member of the Cuyahoga Formation (Lower Mississippian). The eastern sandstone body known as the "Maxton" sandstone is correlated to the Sharon Sandstone and conglomerate (lowermost Pennsylvanian). The "Big Injun" should not be used for disposal of oilfield brines because of its importance as a source of potable and brackish water. Better disposal sites are in the middle and southeast parts of the study area.

March, M., 2002, A study of macroinvertebrate communities in Reach Six of Huff Run to determine water quality: Huff Run Watershed Restoration Partnership, 6 p., accessed on September 18, 2006, at http://www.huffrun.org/macrostudy. $p d f$

Assessment of Huff Run was performed using macroinvertebrate populations living in the upper and lower part of the stream, but not for Reach Six, which is a middle section of the stream. In this study, Hester-Dendy traps and kick nets were used to collect macroinvertebrate samples in Reach Six and in the upper and lower parts of the stream for comparisons. Conductivity and $\mathrm{pH}$ were also measured in the field. Macroinvertebrates were identified to the family level. With this data, Cumulative Index Values (stream quality index), Jaccard's Index (similarity) and the Shannon Index (Diversity) were calculated. Results indicate that Reach Six is a poor habitat with low diversity and is in need of further restoration.

Martin, W.D., 1998, Geology of the Dunkard Group (Upper Pennsylvanian-Lower Permian) in Ohio, West Virginia, and Pennsylvania: Ohio Department of Natural Resources, Division of Geological Survey, Bulletin 73, 49 p.

The Dunkard Group rocks have been studied for more than 100 years, and their age is still controversial. This bulletin does not resolve the age controversy but describes previous studies and provides information on lithofacies, clasticrock composition, petrology, fossils, and depositional environments.

Masters, R.W., and Razem, A.C., undated, Review of literature on buried valleys, northeastern Ohio: Columbus, Ohio, U.S. Geological Survey, 30 p. (unpublished, available from U.S. Geological Survey, Ohio Water Science Center Library, Columbus, Ohio).

This is an unpublished manuscript prepared for the U.S. Geological Survey's Regional Aquifer System Analysis (RASA) program describing generalized characteristics of unconsolidated aquifers in northeast Ohio. An annotated bibliography includes references also cited herein. The study area is bounded on the south by Holmes, Tuscarawas, Carroll, and Columbiana Counties.

Matisoff, G., Khourey, C.J., and Hall, J.F., 1981, The source and transport of arsenic in northeastern Ohio groundwaters: Ohio State University Water Resources Center Report 712435, $53 \mathrm{p}$.

Groundwater in the area of Canal Fulton, Ohio, was examined for its hydrologic and chemical properties. Arsenic concentrations were greater than the USEPA Maximum Contaminant Level in two wells, but were elevated above the background value throughout much of the area. Within the study area, there was no evidence for an anthropogenic source of arsenic to the groundwater. Agricultural soils, abandoned underground coal mines, industrial impoundments to the north, and an abandoned industrial dump site within the study area were all eliminated as possible sources of the arsenic.

Matisoff, G., Khourey, C.J., Hall, J.F., Varnes, A.W., and Strain, W.H., 1982, Nature and source of arsenic in northeastern Ohio ground water: Ground Water, v. 20, no. 4, p. $446-456$.

Maxson, G., 1975, Land capability analysis, Stark County: Columbus, Ohio, Ohio Department of Natural Resources, County Report 3, 125 p.

Ohio Department of Natural Resources' Land Capability Analysis Program (OCAP) began in October 1972 and was designed to gather information about the environment (such as vegetation, soils, and groundwater) and to analyze the ability of these components to support different land uses. This report describes statistics of Stark County in 1975. In 1974, land use was 30.3 percent cover and grassland, 19 percent agriculture, 16 percent woodland, 16 percent residential, 9.7 percent scrubland, 1.2 percent commercial, 1.2 percent industrial, 0.8 percent water or marsh, and 5.6 percent other.

Mayasich, J., Grandmaison, D., and Phillips, C., 2003, Eastern hellbender status assessment report: U.S. Fish and Wildlife 
Service, NRRI/TR-2003/09, 41 p., accessed September 27, 2006, at http://www.fws.gov/midwest/eco_serv/soc/ amphibians/eahe-sa.pdf

Mayhew, G.H., 1985, Contamination investigation of the south wellfield for the city of Wooster, Ohio: Massillon, Ohio, Ohio Drilling Company $17 \mathrm{p}$.

McCormick, G.R., 1961, Petrology of Precambrian rocks of Ohio: Ohio Department of Natural Resources Report of Investigation 41, 60 p., 42 figs., 17 tables.

McCurdy, D.E., Garbarino, J.R., and Mullin, A.H., 2008, Interpreting and reporting radiological water-quality data: U.S. Geological Survey Techniques and Methods, book 5, chap. B6, 33 p.

McShaffrey, D., and Olive, J., 1985, Ecology and distribution of chironomid larvae from Carroll County, Ohio (Diptera:Chironomidae): Ohio Journal of Science, v. 85, no. 4, p. 190-198.

The study focused on sampling the Upper North Fork and Sandy Creek because these streams "... are desirable candidates for future biological monitoring projects." The larvae of the family Chironomidae were collected from lotic and lentic sites from October 1981 to October 1982, and a total of 80 species was found. The number of species was comparable to that reported in other studies.

Medina Soil Conservation District, 1960, Watershed work plan: Chippewa Creek Watershed, Medina and Wayne counties, Ohio: Columbus, Ohio, Ohio Department of Natural Resources, variously paginated.

Moore, R.H., 2006, The Sugar Creek Method-An example of community-based watershed management, accessed September 21, 2006, at http://sugarcreekmethod.osu.edu/

In 2000, the Ohio Environmental Protection Agency labeled the Sugar Creek Watershed the second most impaired watershed in Ohio. Twenty-one sampling sites were established in 2001 and were sampled bi-monthly for $\mathrm{pH}$, total solids, and nutrients. Results indicated high total dissolved solids were associated with high residential areas, and high nitrate concentrations were associated with industrial confined feedlots and crops. In contrast, high proportions of pasture and forest cover were associated with low concentrations of nitrate and ammonia, and high concentrations of phosphate were associated with farming.

Morrison, L., 1996, Seismic refraction studies of paleodrainage in the Muskingum River Valley, Muskingum County, Ohio: Athens, Ohio, Ohio University, Ph.D. dissertation, $170 \mathrm{p}$.

Morse, H.H., 1939, Erosion and related land use conditions on the Muskingum River watershed: U.S. Soil Conservation Service, $36 \mathrm{p}$.
Morse, W.C., 1910, The Maxville limestone: Ohio Department of Natural Resources Bulletin 13, 128 p.

Multer, H.G., 1963, Ohio geology of the Silurian producing zones in the Moreland oil pool, Wayne County, northeastern Ohio: Ohio Department of Natural Resources Report of Investigation $46,48 \mathrm{p}$.

Multer, H.G., 1967, Bedrock geology of Wayne County, Ohio: Ohio Department of Natural Resources, Division of Geological Survey, Report of Investigations 61, scale 1:62,500.

Surface exposure of bedrock in Wayne County is dominated by the Cuyahoga and Logan Formations (middle and upper Mississippian age), some Pottsville and minor Alleghany group (Pennsylvanian age). The report also provides a detailed stratigraphic section of rocks and description of mineral resources.

Multi-Resolution Land Characteristics Consortium, 2008, National Land Cover Database (NLCD) 1992/2001 Retrofit Land Cover Change Product, accessed January 17, 2009, at http://www.mrlc.gov/index.php.

Muskingum River Basin Initiative, 2005, The Muskingum River Basin, accessed September 12, 2006, at http://www. muskingumbasin.com/

This Web page summarizes the Muskingum River Basin Systems Operations Study.

Muskingum Watershed Conservancy District, 2002, The Chippewa Creek Watershed Project, accessed September 12, 2006, at http://www.mwcdlakes.com/chippewa/index.htm

This Web page describes the number of dams and the physical characteristics of the watershed, and explains how and why an additional assessment is being applied to homeowners in this watershed to be used to reduce flooding.

Muskingum Watershed Conservancy District, 2008, Muskingum Watershed Conservancy District home page, accessed July 24, 2008, at http://www.mwcd.org/index.shtml

National Oceanic and Atmospheric Administration, 2002, Monthly station normals of temperature, precipitation, and heating and cooling degree days 1971-2000, accessed December 18, 2007, on http://www.lib.muohio.edu/epub/ govlaw/climate/OHnorm.pdf

National Oceanic and Atmospheric Administration, 2008, Advanced Hydrologic Prediction Services, accessed on April 5, 2008, on http://www.weather.gov/ahps/index.php

Natural Resources Conservation Service, 1998a, Soil survey of Harrison County, Ohio: Washington, D.C., U.S. Natural Resources Conservation Service, $300 \mathrm{p}$. 
Natural Resources Conservation Service, 1998b, Soil survey of Holmes County, Ohio: Washington, D.C., U.S. Natural Resources Conservation Service, 281 p.

Natural Resources Conservation Service, 1999, Digital map of 14-digit hydrologic unit boundaries and codes, accessed February 19, 2008, at http://www.oh.nrcs.usda.gov/ technical/14-digit/index.html

Natural Resources Conservation Service, 2001, Keeping Ohio dams safe, accessed June 21, 2006, at http://www.nrcs.usda. gov/Programs/ws_reinvent/keep_dams_safe/Chip3A.pdf

This report describes dam issues in Ohio, including the Chippewa Creek Watershed Pilot Rehabilitation Project. Constructed in 1980, the dam needs to be upgraded because of downstream development. Rehabilitation includes reconstruction and widening of the auxiliary spillway and limited removal of sediment.

Natural Resources Conservation Service, 2002, Soil survey of Coshocton County, Ohio: Washington, D.C., U.S. Natural Resources Conservation Service, 418 p.

Natural Resources Conservation Service, 2005, Soil survey of Guernsey County, Ohio: Washington, D.C., U.S. Natural Resources Conservation Service, 434 p.

Northeast Ohio Four County Regional Planning and Development Organization, 1975, Water resources inventory: goals \& policies, systems facilities, plans \& proposals: Akron, Ohio, Northeast Ohio Four County Regional Planning and Development Organization, variously paginated.

Northeast Ohio Four County Regional Planning and Development Organization, 1985, Non-point source assessment, Upper Tuscarawas Watershed, Summit County, Ohio: Akron, Ohio, Northeast Ohio Four County Regional Planning and Development Organization, $182 \mathrm{p}$.

The purpose of the Upper Tuscarawas Watershed Non-Point Source Assessment was to identify nonpoint sources of pollution, environmental effects, and areas of origin. This study also called for a system to assign contamination-control priorities. The report examines the extent to which potential solutions or best management practices (BMPs) need to be applied to the watershed, the cost of BMP application, and the estimated effect on water quality.

The report provides land-use data for the watershed, which is 22 percent cropland, 21.6 percent residential, 20.3 percent rangeland, 14.4 percent forest, 8.5 percent transportation, 3.5 percent water, and 1.7 percent commercial.

Northeast Ohio Four County Regional Planning and Development Organization, 1999a, Upper Tuscarawas River Basin Action Plan, Final Report, accessed March 15, 2005, at http://www.uptuscwatershed.org/upper_tuscarawas_action_ plan.htm
The Upper Tuscarawas River (Portage Lakes) Watershed is an area of mixed development with increasing conversion of agricultural and open space to single family and commercial development. On-lot home and semi-public sewage disposal systems (HSDSs and SPSDSs), landfills and dumps, and construction sites appear to have the greatest potential effect as nonpoint-source contamination sites as a whole. Other point sources include municipal wastewater-treatment plants, several smaller semi-public sewage-treatment plants (package plants), and industrial dischargers.

Northeast Ohio Four County Regional Planning and Development Organization, 1999b, Upper Tuscarawas River comprehensive watershed management plan-Phase 1, Executive Summary, accessed September 12, 2006, at http://www. uptuscwatershed.org/tusc_river/reports/executive_summary/ upper_tusc_ex_summary.pdf

This summary includes descriptions of land use in subwatersheds and potential contamination sources. Three surface-water sites had fecal coliform concentrations in excess of 1,000 colonies per $100 \mathrm{~mL}$. "...Groundwater resources are among the most important.” Biologically significant watersheds are mostly on western boundary of watershed.

Northeast Ohio Four County Regional Planning and Development Organization, 1999c, Upper Wolf Creek Comprehensive Basin Management Plan Phase II-Basin Monitoring, accessed October 10, 2006, at http://www.uptuscwatershed. org/upper_wolf_creek_cwmp_II.htm

Northeast Ohio Four County Regional Planning and Development Organization, 2001a, Basin Action Plan with Cost Estimates, accessed March 15, 2001, at http://www. uptuscbasin.org/upper_tuscarawas_action_plan_w_costs. htm

Northeast Ohio Four County Regional Planning and Development Organization, 2001b, Nimishillen Creek Watershed Profile, accessed September 12, 2006, at http://www. uptuscbasin.org/nimishillen_creek/reports/nimishillen_ watershed_profile.PUB

This is a newsletter providing basic watershed background information, including land use in each sub-watershed (overall land use was dominated by greater than 50 percent open/vegetation; 25 to 50 percent urban; and less than 10 percent industrial), potential contaminant point sources (56 domestic- and 29 industrial-waste discharges were identified) and nonpoint sources (unsewered areas, agriculture, construction, and urban runoff), quality of riparian habitat, and water-quality conditions (21.4 percent in partial attainment and 69.7 percent in nonattainment).

Northeast Ohio Four County Regional Planning and Development Organization, 2003, Nimishillen Creek macroinvertebrate study, accessed September 12, 2006, at http://www. uptuscwatershed.org/nimishillen_survey.html 
Chemical, bacterial, and macroinvertebrate monitoring was done at 16 sites in the Upper Wolf Creek Watershed, a tributary to the Tuscarawas River, to assess stream health and to characterize nutrient and sediment concentrations originating in the watershed. Field sampling did not show any unusually high levels of nutrients, iron, suspended solids, biological oxygen demand, fecal coliform, E. coli, temperature, or $\mathrm{pH}$. Levels appear to be relatively low in comparison to other watersheds in the region. However, iron levels were greater than $1,000 \mu \mathrm{g} / \mathrm{L}$ (micrograms per liter) in summer months. Fecal coliform and E. coli counts also were elevated during summer months just after or during a rain event in June. Failing home sewage disposal systems are probable sources. Macroinvertebrate surveys revealed excellent water quality at three of four stations. The report recommended continued monitoring.

Northeast Ohio Four County Regional Planning and Development Organization, 2004, Upper Tuscarawas River Region Watersheds, accessed February 22, 2006, at http://www. uptuscwatershed.org

Northeast Ohio Four County Regional Planning and Development Organization, 2005, Nimishillen Creek Macroinvertebrate Survey: 18 p., accessed on December 12, 2006, at http://www.uptuscwatershed.org/nimishillen_survey_2004. htm

Northeast Ohio Four County Regional Planning and Development Organization (NEFCO) identified and surveyed a total of 17 sites in Nimishillen Creek and its tributaries. The same sites were sampled in 2000, 2002, and 2004 (see also NEFCO, 2003). " ...In general, the 2004 results of the macroinvertebrate monitoring were slightly lower than in 2000 and 2002. However, the data still implies that the waters of the Nimishillen Creek watershed, in the vicinity of Canton, are of relatively fair quality, but are most likely still not meeting the designated standards. NEFCO observed that the in-stream habitat and macroinvertebrate data showed that streams with poor to fair macroinvertebrate counts had habitat similar to sites that had good to excellent macroinvertebrate counts. Sherrick Run is strongly impacted by AMD. Sampling of additional parameters (chemical, bacterial, and water flow) may provide more data to characterize water quality within the Nimishillen Creek watershed."

Oelker, E.F., Boone, K.M., and Brown, L.C., undated a, Stark County water resources: Ohio State University Extension Fact Sheet AEX-480.76, accessed September 20, 2006, at http://ohioline.osu.edu/aex-fact/0480_76.html

This fact sheet is an overview of water resources for Stark County, including precipitation, groundwater, surface water, water use, and water quality. Average rainfall for the county is 37 inches per year, providing 9.5 inches of runoff to streams and lakes. About 6 inches of rainfall has the potential to recharge aquifers. Land use is 43 percent farmland. Nitrate is a water-quality issue and volatile organic compound contamination is present in the area of Uniontown.

Oelker, E.F., Boone, K.M., and Brown, L.C., undated b, Summit County water resources: Ohio State University Extension Fact Sheet AEX-480.77, accessed November 20, 2006, at http://ohioline.osu.edu/aex-fact/0480_77.html

This fact sheet is an overview of water resources for Summit County, including precipitation, groundwater, surface water, water use, and water quality. Average rainfall for the three-county area is 37 inches per year, providing 9.6 inches of runoff to streams and lakes, and about 6 inches of rainfall has the potential to recharge aquifers. Land use is 8.7 percent farmland. Nitrate is a water-quality issue, as is volatile organic compound contamination at Uniontown and adjacent area of Green Township in Summit County.

Oelker, E.F., Jones, W.A., Brown, L.C., and Boone, K.M., undated c, Stark County ground-water resources: Ohio State University Extension Fact Sheet AEX-490.76, accessed September 20, 2006, at http://ohioline.osu.edu/aexfact/0490_76.html

This is an overview of Stark County's groundwater resources, including definitions of aquifer and well yield. A generalized map of well yields shows the Ohio Department of Natural Resources observation wells sites and sites where samples were collected for chemical analysis.

Oelker, E.F., Raab, J.M., Brown, L.C., and Boone, K.M., undated d, Summit County ground-water resources: Ohio State University Extension Fact Sheet AEX-490.77, accessed November 20, 2006, at http://ohioline.osu.edu/ aex-fact/0490_77.html

This is an overview of Summit County's groundwater resources, including definitions of aquifer and well yield. Sites of Ohio Department of Natural Resources observation wells and sites where samples were collected for chemical analysis are shown on a generalized map of well yields. Industrial Excess landfill in neighboring Stark County may be source of volatile organic compounds.

Office of Surface Mining, 2000, Reclamation and Enforcement Annual Evaluation Summary Report: Evaluation Year 2000: Office of Surface Mining Reclamation and Enforcement, variously paginated, accessed December 12, 2006, at http://www.osmre.gov/oversight/ohio00.htm

"The Surface Mining Control and Reclamation Act of 1977 (SMCRA) provides authority to the Office of Surface Mining to oversee the implementation of and provide Federal funding for State regulatory programs that OSM has approved as meeting the minimum standards specified by SMCRA. This report contains summary information regarding the Ohio Program and the effectiveness of the Ohio Program in meeting the applicable purposes of SMCRA as 
specified in section 102. This report covers the period of October 1, 1999, to September 30, 2000.”

Regarding Huff Run, “...The Huff Run Watershed Restoration Partnership (HRWRP) is working with the Crossroads Resource Conservation and Development Council (RC\&D) of the NRCS. They received an Ohio EPA 319 grant to fund several projects in partnership with the group and Ohio."

Office of Surface Mining, 2009, Surface Mining Law, accessed September 24, 2009, at http://www.osmre.gov/ topic/SMCRA/SMCRA.shtm

This web page contains Public Law 95-87, the Surface Mining Control and Reclamation Act of 1977 (SMCRA), passed August 3, 1977, and all revisions through December 31, 1993.

Ohio Department of Health, 1958, Report of water pollution study of Muskingum River Basin, 1951 -1953-1954: Columbus, Ohio, Ohio Department of Health, Sewage and Industrial Waste Unit, $116 \mathrm{p}$.

This report describes a surface-water reconnaissance of the entire Muskingum River Basin. 1950 population of the basin was 916,600. Survey data and analyses of their significance provides evidence that damaging effects on water quality existed at the time of the survey which impaired reasonable and necessary water uses, endangered public health, and caused nuisance conditions. Recommendations focus on reduction in municipal wastes, industrial wastes, organic pollution and several (listed) focal points; adequate and continuous disinfection of sewage and industrial wastes; effective removal of solids from mill scale, blast furnace, and other waste effluents; effective removal of grease and oil from waste effluents; neutralization of waste pickle liquors; elimination of discharge of concentrated brines; removal or reduction of phenolic constituents; modification or controlled discharge of industrial wastes containing toxic materials; and modification or control of miscellaneous wastes not specified in this report.

The report documents chloride contamination from the Morton Salt Company and the Columbia-Southern Chemical Corporation affiliated with Pittsburgh Plate Glass Company in the Tuscarawas River. These companies operated brine wells in the vicinity of Barberton-Rittman. Morton Salt discharged directly to Tuscarawas River at Clinton by way of Chippewa Creek. Columbia Southern Chemical put brines in settling lagoons. Data from 1950 show the surface water at the Tuscarawas River at Massillon had an average chloride concentration of 5,754 ppm, and the Tuscarawas River at Newcomerstown had an average chloride concentration of $976 \mathrm{ppm}$.

Ohio Department of Health and Ohio Water Pollution Control Board, 1968, Report and recommendations on water quality for Muskingum River Basin: Columbus, Ohio, Ohio Department of Health, Division of Engineering, 85 .
Ohio Department of Natural Resources, 1963, The story of Ohio's mineral resources: Ohio Department of Natural Resources Information Circular 9, 14 p.

Ohio Department of Natural Resources, 1968, Water inventory of the Muskingum River Basin and adjacent Ohio River tributary areas: Ohio Water Plan Inventory Report 21, $201 \mathrm{p}$.

This inventory of the basin identifies water problems and recommends projects to address these problems. "...By the year 2000 municipal water demands will have tripled 1960 use rates, but will not have exceeded potential supplies. Major problems to be faced are those of improving water quality and providing some additional flood protection. A water plan should provide: reduced chloride concentrations accomplished at least in part by reduction in total chloride level, streamflow regulation from reservoir storage or from wells to concentrations of undesirable waste materials, urban flood protection, agricultural flood protection, water supply reservoirs for at least 39 communities, additional wells for at least 93 communities, new well water supplies for 19 other communities, improved waste treatment facilities for 18 municipalities plus additional facilities at 28 more communities, and fullest recreational use." Recommended projects include restudy of the entire Muskingum reservoir system, completion of a multipurpose reservoir on the north branch of the Kokosing, a multipurpose reservoir on the North Fork of the Licking River near Utica, development of work plans for six small watersheds, and construction of the Chippewa Creek and Buffalo Creek work plans. The inventory also provides summary land use and population data by county.

Ohio Department of Natural Resources, 1971, Interim plan for pollution abatement of the Tuscarawas River basin (STORET Basin 0504): a phase of the Southeast Ohio water development plan: Columbus, Ohio, Ohio Department of Natural Resources, unpaginated.

Ohio Department of Natural Resources, 1972, Wolf Creek Wildlife Area: Ohio Department of Natural Resources, Division of Wildlife, scale 1:33,000.

Ohio Department of Natural Resources, 1974a, Conotton Creek subwatershed analysis: Ohio Department of Natural Resources, Mined Lands Restoration Unit Report 1, 116 p.

Ohio Department of Natural Resources, 1974b, Land capability analysis: the Wolf Creek project: Columbus, Ohio, Ohio Department of Natural Resources, Division of Planning, $55 \mathrm{p}$.

Ohio Department of Natural Resources, 1976, Bedrock topography of Medina County: Ohio Department of Natural Resources, Division of Geological Survey, Open File Map 219 , scale $1: 62,500$. 
Bedrock topography is shown on topographic base county maps at a scale of 1:62,500. The county base maps were composited in the 1970s. Bedrock-topography compilation dates range from 1971 to 1989 . These maps have been superseded by the 1:24,000-scale bedrock-topography maps.

Ohio Department of Natural Resources, 1978a, Drift thickness of Medina County: Ohio Department of Natural Resources, Division of Geological Survey, Open File Map 225, scale 1:62,500.

Thickness contours of the unconsolidated glacial deposits in Medina County are shown on topographic base county maps at a scale of 1:62,500. The county base maps were composited in the 1970s. Compilation dates range from 1971 to 1989. These maps have been superseded by the 1:24,000scale glacial maps.

Ohio Department of Natural Resources, 1978b, Southeast Ohio water plan: Ohio Department of Natural Resources, Division of Water, $517 \mathrm{p}$.

This plan provides a comprehensive document for the development and management of the region's water resources with particular emphasis on water supply and flood control with projections to the year 2020. The study area includes all of the Muskingum River Basin and provides summary data and projections for every community within the basin.

Ohio Department of Natural Resources, 1983, Drift thickness of Portage County: Ohio Department of Natural Resources, Division of Geological Survey, Open File Map 205, scale 1:62,500.

Thickness contours of the unconsolidated glacial deposits in Portage County are shown on topographic base county maps at a scale of 1:62,500. The county base maps were composited in the 1970s. Compilation dates range from 1971 to 1989. These maps have been superseded by the 1:24,000scale glacial maps.

Ohio Department of Natural Resources, 1993a, Quaternary geology of Canton quadrangle: Ohio Department of Natural Resources, Division of Geological Survey, Open File Map 296, scale 1:250,000.

These hand-drafted maps, compiled from published and unpublished sources, depict the surficial glacial and alluvial deposits of the Canton quadrangle at a scale of 1:250,000.

Ohio Department of Natural Resources, 1993b, Quaternary geology of Cleveland quadrangle: Ohio Department of Natural Resources, Division of Geological Survey, Open File Map 293, scale 1:250,000.

These hand-drafted maps, compiled from published and unpublished sources, depict the surficial glacial and alluvial deposits of the Cleveland quadrangle at a scale of 1:250,000.

Ohio Department of Natural Resources, 1997a, History of coal mining in Ohio: Geofacts No. 14, accessed December 4, 2006, at http://www.dnr.state.oh.us/Portals/10/pdf/ GeoFacts/geof14.pdf

Ohio Department of Natural Resources, 1997b, Ohio and Erie Canal/Hydraulic Operations: Ohio Department of Natural Resources, Division of Water, Fact Sheet 97-41, 3 p., accessed December 12, 2006, at http://www.dnr.state.oh.us/ water/pubs/fs_div/fctsht41.htm

Details are provided regarding the drainage and flow characteristics of the Portage Lakes, which include the East Reservoir, West Reservoir, Turkeyfoot Lake, North Reservoir, and Long Lake.

"The Portage Lakes, located south of the City of Akron, were originally constructed in the 1830 's to supply water to the Ohio \& Erie Canal. The reservoirs were retained by the state for recreational development and water supply. Due to the expansion of industry and the demand for raw water, Nimisila Reservoir and Tuscarawas Diversion Dam were built in 1936 and 1956, respectively, to augment water supply from the Portage Lakes and the canal."

Ohio Department of Natural Resources, 1999a, Abandoned Underground Mines (Shafts) - Statewide, theme ID 1900, accessed October 10, 2008, at http://www.ohiodnr.com/ gims/category/tabid/10528/Default.aspx

Ohio Department of Natural Resources, 1999b, Probable Abandoned Underground Mines - Statewide, theme ID: 1901, accessed October 10, 2008, at http://www.ohiodnr. com/gims/category/tabid/10528/Default.aspx

Ohio Department of Natural Resources, 2000a, Drift thickness of Ohio: Ohio Department of Natural Resources, Division of Water, scale 1:500,000, accessed October 24, 2006, at http://www.dnr.state.oh.us/water/samp/

The maps and data are available as pdf files or GIS data layers. GIS data layers also can be ordered on a CD that contains additional base map files and supporting documentation. The maps were compiled from 1:24,000 data.

Ohio Department of Natural Resources, 2000b, Primary lithology of the unconsolidated deposits of Ohio: Ohio Department of Natural Resources, Division of Water, scale 1:500,000, accessed October 24, 2006, at http://www.dnr.state.oh.us/water/samp/

The maps and data are available as pdf files or GIS data layers. GIS data layers also can be ordered on a CD that contains additional base map files and supporting documentation. The maps were compiled from 1:24,000 data. 
Ohio Department of Natural Resources, 2000c, Yields of the unconsolidated aquifers of Ohio: Ohio Department of Natural Resources, Division of Water, scale 1:500,000, accessed October 24, 2006, at http://www.dnr.state.oh.us/water/samp/ The maps and data are available as pdf files or GIS data layers. GIS data layers also can be ordered on a CD that contains additional base map files and supporting documentation. The maps were compiled from 1:24,000 data.

Ohio Department of Natural Resources, 2000d, Yields of the uppermost bedrock aquifers of Ohio: Ohio Department of Natural Resources, Division of Water, scale 1:500,000, accessed October 24, 2006, at http://www.dnr.state.oh.us/ water/samp/

The maps and data are available as pdf files or GIS data layers. GIS data layers also can be ordered on a CD that contains additional base map files and supporting documentation. The maps were compiled from 1:24,000 data.

Ohio Department of Natural Resources, 2006, Industrial minerals and coal mining permitted locations, theme ID: 2959, accessed October 10, 2008, at http://www.ohiodnr.com/ gims/category/tabid/10528/Default.aspx

Ohio Department of Natural Resources, 2007a, 2006 report on Ohio mineral industries: An annual summary of the state's economic geology, 205 p. accessed December 17, 2007, at http://www.dnr.state.oh.us/Portals/10/pdf/min_ind_ report/06minind.pdf

This is a summary report of Ohio's mineral industry including detailed summaries of coal production numbers for the year and long-term trends in minerals production.

Ohio Department of Natural Resources, 2007b, Oil and gas fields map of Ohio: Ohio Department of Natural Resources single-page map, accessed December 15, 2007, at http://ohiodnr.com/Portals/10/pdf/pg01.pdf

Ohio Department of Natural Resources, 2008a, Dam definition, classification and statistics, Division of Water Dam Safety, accessed April 5, 2008, at http://www.dnr.state.oh.us/ water/dsafety/default/tabid/3329/Default.aspx

Ohio Department of Natural Resources, 2008b, Division of Soil and Water Conservation, Soils Regions of Ohio General Soils Map and Information, accessed August 15, 2008, at $h t t p: / / w w w . d n r . s t a t e . o h . u s / t a b i d / 9068 /$ default.aspx

Ohio Department of Natural Resources, 2008c, The hydrologic cycle or water cycle: Fact Sheet 93-18, accessed June 18, 2008, at http://ohiodnr.com/water/pubs/fs_div/fctsht18/ tabid/4101/Default.aspx

Ohio Department of Public Works and Dayton Morgan Engineering Co., 1931, Report on water resources of Muskingum drainage area: Dayton, Ohio, Dayton Morgan Engineering Co., 44 p.
Ohio Drilling Company, 1971, Ground water potential of northeast Ohio: Massillon, Ohio, The Ohio Drilling Company, $360 \mathrm{p}$.

This report focuses on the potential groundwater supply in several preglacial buried river valleys in northeast Ohio, including those in the Chippewa Area. Seismic profiling was used to establish a cross section or rock profile of the buried valley. Electric resistivity logs show the depth of valley up to $300 \mathrm{ft}$ deep. Seven test holes were drilled to determine the type of fill material in the valley. It was estimated that 75 to $150 \mathrm{gal} / \mathrm{min}$ can be obtained from a clean sand and gravel layer present along the western flank of the valley.

Ohio Environmental Protection Agency, 1978, Water quality management plan, part III: Muskingum River basin: Columbus, Ohio, Ohio Environmental Protection Agency.

Ohio Environmental Protection Agency, 1979, Initial water quality management plan, Muskingum River basin: Columbus, Ohio, Ohio Environmental Protection Agency.

Ohio Environmental Protection Agency, 1994a, Biological and water quality study of the East Branch Nimishillen CreekStark County, Ohio: Ohio Environmental Protection Agency Technical Report EAS/1994-6-6, 69 p.

During 1993, 12 fish and macroinvertebrate sites on the East Branch Nimishillen Creek were sampled. Results indicate that 1.7 miles of stream were in partial attainment and 7.5 miles of stream were in non-attainment of warmwater biological criteria. Exceedances of chemical waterquality criteria were not recorded at any sampling locations upstream of J\&L Specialty Products outfalls. Exceptionally high nitrate-nitrite concentrations (up to $170 \mathrm{mg} / \mathrm{L}$ ) were recorded below J\&L Specialty Products. Concentrations of dissolved oxygen were low and concentrations of total dissolved solids were high up to 2.65 miles downstream from the site.

Ohio Environmental Protection Agency, 1994b, Biological and water quality study of the River Styx: Ohio Environmental Protection Agency Technical Report SWS/1994-6-8, 25 p.

A total of 3.5 river miles along River Styx were evaluated for warm-water criteria. The upper 0.6 miles were in full attainment; the lower 2.9 miles were in non-attainment. Wastewater discharges account for approximately 97 percent of streamflow.

Ohio Environmental Protection Agency, 1994c, Biological, sediment and water quality study of the Tuscarawas River, Wolf Creek and Hudson Run, Summit and Stark Counties: Ohio Environmental Protection Agency Technical Report EAS/1994-8-7, 102 p., accessed June 21, 2006, at http://www.epa.state.oh.us/dsw/documents/tuscppg.pdf 
Fish consumption advisories were based on fish tissue results from 1989 and 1993, which found elevated levels of polychlorinated biphenyls (PCBs) and hexachlorobenzene (HCB) in fish tissue. High concentrations of HCB also were found in sediment in the Tuscarawas River from Wolf Creek to the downstream end of study area, and in Hudson Run Reservoir adjacent to PPG Industries. Numerous samples exceeded the Severe Effect Level (a level above which sediment is considered heavily contaminated and likely to affect the health of sediment-dwelling organisms), with the highest concentration at $852 \mu \mathrm{g} / \mathrm{kg}$ (micrograms per kilogram). Other chlorinated benzenes and elevated metals concentrations also were present in sediment samples. Several spills associated with the PPG site occurred between 1980 and 1991, consisting predominantly of silica solids/sodium silicate, wastewater, and hydrochloric acid. HCB was present in six surface-water samples.

Ohio Environmental Protection Agency, 1995a, Biological and water quality study of Upper Sandy Creek and Still Fork Sandy Creek-Stark, Carroll and Columbiana Counties, Ohio: Ohio Environmental Protection Agency Technical Report EAS/1994-5-4, 65 p.

Poorly treated organic wastes from the Minerva Wastewater Treatment Plant had a substantial effect on biological and chemical water conditions in Sandy Creek. All biological indices declined to poor at a station 0.7 miles downstream. Sharp increases in ammonia nitrogen and phosphorous also were noted.

Ohio Environmental Protection Agency, 1995b, Fish tissue study of the Tuscarawas River and Sugar Creek, Tuscarawas County; Dover Chemical (Dover, Ohio) and Alsco Anaconda (Gnadenhutten, Ohio): Ohio Environmental Protection Agency Technical Report MAS/1995-3-5, 18 p.

2,3,7,8-Tetrachlorodibenzo-p-dioxin (2,3,7,8-TCDD), 2,3,7,8-tetrachlorodibenzofuran (2,3,7,8-TCDF), and other dioxin and furan congeners were analyzed in fish collected from the Tuscarawas River at Dover and from Sugar Creek. Elevated levels of PCBs were present in Tuscarawas River fish collected at locations both upstream and downstream from the Sugar Creek confluence (Dover Chemical) and Alsco Anaconda. The highest PCB levels in the study area were reported for common carp. Hexachlorobenzene was detected in all Tuscarawas River and Sugar Creek fish tissue samples. Monitoring of various chlorinated pesticides in fish tissue at all sampling sites revealed concentrations less than FDA Action Levels. One common carp fish tissue sample collected at RM 39.6 (upstream from Alsco Anaconda, at US 36) contained elevated concentrations of alpha-BHC (63 $\mu \mathrm{g} / \mathrm{kg})$, gamma-BHC (lindane) $(25 \mu \mathrm{g} / \mathrm{kg})$, delta-BHC $(38 \mu \mathrm{g} / \mathrm{kg})$, heptachlor epoxide $(270 \mu \mathrm{g} / \mathrm{kg})$, endosulfan I (20 $\mu \mathrm{g} / \mathrm{kg}), 4,4^{\prime}-\mathrm{DDD}(140 \mu \mathrm{g} / \mathrm{kg})$, and methoxychlor $(320 \mu \mathrm{g} / \mathrm{kg})$.
Ohio Environmental Protection Agency, 1996a, Biological and sediment study of the Tuscarawas River, Tuscarawas and Stark Counties, Ohio-Ashland Oil spill, June 1995: Ohio Environmental Protection Agency Technical Report MAS/1996-2-1, 24, [66], accessed December 19, 2006, at http://www.epa.state.oh.us/dsw/documents/tuscspll.pdf

A pipeline construction company laying a new high pressure petroleum pipeline in close proximity to an active high pressure crude oil transmission pipeline operated by Ashland Pipeline sheared off a valve within 50 feet of the Tuscarawas River on June 7, 1995. More than 300 barrels of crude oil discharged to the Tuscarawas River approximately 7 miles upstream from Bolivar. Containment booms were deployed at several locations downstream with limited success; eventually, the crude oil was contained behind Dover Dam, approximately 16 miles downstream from the spill site. The dam and containment boom stopped most of the crude oil with only a sheen passing through the dam.

Ohio Environmental Protection Agency, 1996b, Biological and water quality study of the Upper Killbuck Creek Watershed-Medina, Wayne, Holmes, and Coshocton Counties, Ohio: Ohio Environmental Protection Agency Technical Report MAS/1994-12-13, 173 p.

Within the upper reaches of Killbuck Creek and in Camel Creek (a headwater tributary), low dissolved oxygen concentrations were common. Macroinvertebrate community performance varied considerably between the headwaters of Killbuck Creek and Wooster, but remained above warmwater habitat biocriterion (marginally good to exceptional ranges). Upgrades at the Wooster wastewater-treatment plant (WWTP) in the late 1980s resulted in a substantial reduction in ammonia loadings and improved water quality immediately downstream. Elevated and extremely elevated levels of arsenic were present in sediments at 8 of 11 sites in Killbuck Creek and 5 tributaries. Within Apple Creek, macroinvertebrate communities were exceptional. In Doughty Creek, continuous daily monitoring revealed dissolved oxygen levels below the minimum WWH criterion $(4 \mathrm{mg} / \mathrm{L}$ ) downstream from Guggisberg Cheese and the Charm Tributary (RM 14.6-14.29). The increasingly large diel dissolved oxygen swings at the remaining downstream stations (RMs 12.9-10.24) indicated substantial background enrichment in the upper reaches of Doughty Creek. Fish and macroinvertebrates were generally in the very good or exceptional ranges at three stations in the headwaters of Doughty Creek and at one station near the mouth. The only other tributary included in this study is in the wetland portion of Shreve Creek (within Killbuck Marsh) where very low dissolved oxygen concentrations were observed. Daytime dissolved oxygen concentrations were consistently at or near zero during summer sampling, reflecting natural conditions within a true wetland stream. 
Ohio Environmental Protection Agency, 1996c, Biological and water quality study of the Upper Muskingum River mainstem and selected tributaries: Tuscarawas, Coshocton, Licking, Muskingum, and Knox Counties: Ohio Environmental Protection Agency Technical Report MAS/1995-8-9, 193 p.

In the lower 7.3 miles of the Tuscarawas River, the river was in partial attainment of excellent water habitat (EWH) aquatic life use upstream from Coshocton and in full attainment of warm water habitat (WWH) from Coshocton to the mouth. Tuscarawas River biological communities generally ranged from marginally good to exceptional throughout the lower stretches. Biological communities immediately upstream and downstream from Stone Container (RM 1.17-0.4) fully attained the existing WWH use designation and reflected minimal effects in the form of organic enrichment. Declines in biological community performance were observed upstream from Coshocton (RM 7.2-3.4). Following the 1988 survey, approximately 45 miles of the Tuscarawas River from Stillwater Creek to Coshocton were upgraded to EWH based on the improved performance of the biological communities. Chlorophyll $a$ sampling of the Upper Muskingum River revealed substantial algal productivity upstream from Stone Container, an indication of high background nutrient levels upstream from Coshocton. A series of small municipalities (Newcomerstown, West Lafayette, and Canal Lewisville) in the lower 20 miles of the Tuscarawas also was considered to be a potential source of enrichment, but these municipalities alone seemed unlikely sources of impairment that persisted 15 to 20 miles downstream.

Ohio Environmental Protection Agency, 1998a, Biological and water quality study of Sandy Creek, Minerva, 1996-1997, Carroll, Stark, and Columbiana Counties, Ohio: Ohio Environmental Protection Agency Technical Report MAS/19973-1, $98 \mathrm{p}$.

A substantial improvement in aquatic and biological conditions occurred between 1996 and 1997 downstream from the Minerva Waste Water Treatment Plant. The fish community sampling results indicated that, prior to July 1996, chemical contaminants were released into Sandy Creek in the vicinity of the Minerva Waste Water Treatment Plant, causing severe toxic conditions for at least 6.6 miles primarily due to highly toxic ammonia concentrations. Macroinvertebrates were dominated by black flies, organisms often found in high numbers in Ohio streams under degraded conditions. The highest polychlorinated biphenols concentrations occurred in common carp in an area that is lake-like due to quarrying operations in the stream channel.

Ohio Environmental Protection Agency, 1998b, Biological and water quality study of Sugar Creek, 1998: Wayne, Stark, Holmes and Tuscarawas Counties, Ohio: Ohio Environmental Protections Agency Technical Report MAS/1999-12-4, $203 \mathrm{p}$.
Most locations surveyed throughout the basin failed to meet assigned aquatic life uses. Exceptions were associated with physiographic features which affected groundwater flow in some areas. Nonpoint source pollution impinged on water quality and aquatic communities throughout the basin. The extent of non-attainment throughout most of the watershed distinguished Sugar Creek as one of the most degraded basins in all of Ohio. Agricultural land use has promoted siltation and habitat destruction across most of the watershed. Polluted runoff from agricultural and mining sources further acted to suppress aquatic life use attainment. Several organic contaminants were detected in the effluent and in the water column in the vicinity of Dover Chemical. Bioassays of the effluent have a record of toxicity over the past 10 years. Pollutant spills and fish kills have also been reported downstream from the company during this period. Dover Chemical produces phosphites and chlorinated hydrocarbon products which are used to manufacture lubricants, plasticizers, flame retardants, and stabilizers. Hydrochloric acid and sodium hypochlorite are process by-products. The effluent contained some organic compounds including, Bis(2-ethylhexyl)phthalate $(1.9 \mu \mathrm{g} / \mathrm{L}), \alpha \mathrm{BHC}(0.38 \mu \mathrm{g} / \mathrm{L}), \beta \mathrm{BHC}(0.088 \mu \mathrm{g} / \mathrm{L}), \delta-\mathrm{BHC}$ $(0.025 \mu \mathrm{g} / \mathrm{L}), \gamma$-BHC $(0.056 \mu \mathrm{g} / \mathrm{L}), 4-4$ 'DDE $(0.022 \mu \mathrm{g} / \mathrm{L})$, heptachlor epoxide $(0.0071 \mu \mathrm{g} / \mathrm{L})$, and hexachlorobenzene $(0.060 \mu \mathrm{g} / \mathrm{L})$.

Ohio Environmental Protection Agency, 1999, Ohio Water Quality Standards, Chapter 3745-1 of the Administrative Code: Columbus, Ohio, Accessed September 24, 2009 at http://web.epa.ohio.gov/dsw/rules/3745-1.html

Ohio Environmental Protection Agency, 2001, Biological and aquatic life use attainment study-Lower Middle Branch Nimishillen Creek, Stark County, Ohio: Ohio Environmental Protections Agency Site Evaluation Report EAS/2001$10-4,18 \mathrm{p}$.

One mile of the middle branch Nimishillen Creek was assessed in 2001: 0.3 miles were in partial attainment and 0.7 were in non-attainment of the warm-water habitat aquatic life use. Results reflect urbanized nature of the lower 1 mile of the stream. It was not apparent from the results that the Union Metal was affecting biological communities.

Ohio Environmental Protection Agency, 2002a, Ohio EPA primary headwater habitat initiative, data compendium, 1999-2000: Habitat, chemistry, and stream morphology data: Ohio Environmental Protection Agency, Division of Surface Water, variously paginated, accessed December 12, 2006, at http://www.epa.state.oh.us/dsw/wqs/headwaters/ PHWH_Compendium.pdf

This report presents and summarizes the physical, chemical, and morphological data that were collected by Ohio Environmental Protection Agency during surveys of primary headwater habitat streams including an unnamed tributary 
to Middle Fork Sugar Creek, two unnamed tributaries to Chippewa Lake, and an unnamed tributary to River Styx.

Ohio Environmental Protection Agency, 2002b, Technical report: Ohio's primary headwater streams-Fish and amphibian assemblages: Ohio Environmental Protection Agency, Division of Surface Water, 41 p., accessed December 12, 2006, at http://www.epa.state.oh.us/dsw/wqs/ headwaters/TechRep_FishAmphibian_2002.pdf

This report summarizes the types of fish and amphibians that have been collected by Ohio Environmental Protection Agency during surveys of primary headwater habitat streams, including an unnamed tributary to Middle Fork Sugar Creek, two unnamed tributaries to Chippewa Lake, and an unnamed tributary to River Styx.

Ohio Environmental Protection Agency, 2002c, Technical report: Ohio's primary headwater streams-Macroinvertebrate assemblages: Ohio Environmental Protection Agency, Division of Surface Water, 25 p., accessed December 12, 2006, at http://www.epa.state.oh.us/dsw/wqs/headwaters/ TechRep_Macroinvert_2002.pdf

This report summarizes macroinvertebrate information collected by Ohio Environmental Protection Agency during surveys of primary headwater habitat streams, including an unnamed tributary to Middle Fork Sugar Creek, two unnamed tributaries to Chippewa Lake, and an unnamed tributary to River Styx. Headwaters are defined as streams with drainage area less than $1 \mathrm{mi}^{2}$ or with the deepest pools less than $40 \mathrm{~cm}$. Insects encountered during the study include mayfly, stonefly, caddis, midge, dragonflies, and flies. Macroinvertebrates were found in 53 percent of all streams with standing or flowing water. Macroinvertebrates were found in all streams that contained vertebrates. Nineteen percent of streams were found to contain macroinvertebrates only. Forty-six percent of the streams contained no evidence of aquatic life at or near the surface of the stream bed.

Ohio Environmental Protection Agency, 2002d, Total maximum daily loads for the Sugar Creek Basin: Final report: Ohio Environmental Protection Agency, Division of Surface Water, $87 \mathrm{p}$.

Major causes of impairment were sedimentation from agricultural activities (more that 70 percent of the basin's land is devoted to agriculture), habitat alteration, nutrient enrichment from agricultural runoff, streambank modification, lack of riparian vegetation, faulty septic systems, and municipal/industrial discharges.

Ohio Environmental Protection Agency, 2003, Biological and aquatic life use attainment study - Stillwater Creek-Starkey Junkyard: Ohio Environmental Protection Agency Site Evaluation Report EAS/2003-11-8, 19 p.
This report is summarized in a slide show (using Powerpoint format) obtained from http://www.brownfieldstsc.org/ pdfs/ohiopres.pdf.

A total of 0.8 miles of Stillwater Creek were assessed in 2003: 0.3 miles were in full attainment and 0.5 miles were in non-attainment. Lead and arsenic concentrations in soil exceed residential standards in all areas. Local activities include a compactor, junk shop, and a scrap yard. Lead also exceeds the commercial/industrial standard. Total petroleum hydrocarbons in soil exceed petroleum standards in the compactor area only. Volatile organic compounds, semi-volatile organic compounds, and polychlorinated biphenyls are all present, but below residential standards. Lead in ground water exceeds the generic standard, and the report states that the lead would "...be verified through monitoring well installation and sampling."

Ohio Environmental Protection Agency, 2004, Ohio 2004 integrated water quality monitoring and assessment report, March 30 2005, accessed March 30, 2005, at http://www. epa.state.ohio.us/dsw/tmdl/2004IntReport/final_2004IR_ maiin_text.pdf

Ohio Environmental Protection Agency, 2005, Biological and water quality study of the Upper Tuscarawas River Basin, Killian Latex Property: Summit County, Ohio: Ohio Environmental Protection Agency Report EAS/2005-12-7, 50 p.

The property has been used commercially since 1910 and included tire manufacturing and production of natural latex items. Based on the performance of the biological communities, the upper 0.4 mile section of the Tuscarawas River was in non-attainment of the warm water habitat (WWH) aquatic life use, and the lower 0.6 miles were in partial attainment of the WWH use. These impaired biological conditions were not associated with chemical constituents released under current conditions at the Killian Latex property or from the Killian National Pollutant Discharge Elimination System (NPDES) permitted discharge. Chemical constituents, including organic compounds and metals, measured in the Tuscarawas River were less than the Ohio EPA criteria; however, nutrients and oxygen-demanding parameters were not tested as part of this study. Sediment concentrations were not at levels likely to cause ecological impairment to the biota of the Tuscarawas River within the study area.

Ohio Environmental Protection Agency, 2006a, 2006 305(b) Report Ohio's Ground Water Quality: Division of Drinking and Ground Waters, accessed April 8, 2008, at http://www. epa.state.oh.us/ddagw/Documents/2006_305b.pdf

Ohio Environmental Protection Agency, 2006b, 2006 integrated water quality monitoring and assessment report: Ohio Environmental Protection Agency, Division of Surface Water, 97 p., accessed September 18, 2006, at http://www. epa.state.oh.us/dsw/tmdl/2004IntReport/2004OhioIntegrate dReport.html 
Nimishillen Creek, the Portage Canal, Sandy Creek, and the Tuscarawas River mainstem from Barberton to New Philadelphia had fish consumption advisories because of PCBs. The Tuscarawas River mainstem from Barberton to New Philadelphia also had a fish consumption advisory because of hexachlorobenzene. At the time of publication, TMDLs were in progress for Sugar Creek.

Ohio Environmental Protection Agency, 2006c, 2006 Ohio sport fish consumption advisory, accessed September 20, 2006, at http://www.epa.state.oh.us/dsw/fishadvisory/

This web page lists fish consumption advisories issued by the Ohio Dept. of Health for sport fish caught in Ohio waters. Advisories are listed by water body. The contaminants causing fish advisories in the Tuscarawas Basin are PCBs and mercury. The Web site recommended that consumers should average no more than one meal of fish from these waters per 1 or 2 months.

Ohio Environmental Protection Agency, 2006d, Bacteria TMDL development for the Sugar Creek Watershed: Holmes, Stark, Tuscarawas, and Wayne Counties, Ohio (draft): Ohio Environmental Protection Agency, Division of Surface Water, Public Review Draft Report, June 2, 2006, 121 p., accessed December 12, 2006, at http://www.epa.state.oh.us/ dsw/tmdl/SugarCreekBacteriaTMDL_draft_jun06.pdf

Ohio Environmental Protection Agency, 2006e, Recreational use water quality survey for the Sugar Creek Watershed 2005: Ohio Environmental Protection Agency Technical Report NEDO/2006-02-01, variously paginated, accessed December 12, 2006, at http://www.epa.state.oh.us/dsw/docu ments/2005FINALSugarCreekBactiReport.pdf

All three assessment units making up the Sugar Creek watershed were in non-attainment for their designated recreational uses. Only 5 of 38 sampling sites were in full attainment for recreational use water-quality criteria. The upper reaches showed marked improvement since 1998. Farming represented a very high percentage of land use and the economic base within the watershed. Agricultural practices related to animal pasturing and animal-waste management were the primary causes of non-attainment. Sources of bacteria and potential pathogens relating to the problem were poorly managed or uncontrolled runoff, failing onsite wastewater systems, construction in northern part of Sugar Creek along the Route 30 corridor in Wayne County and western Tuscarawas County in the triangle between Strasburg, Dover, and Sugarcreek. Altered stream morphology, poor floodplain quality, and disconnection of stream channels played an important part in extremely high fecal coliform and E. coli densities. It was recommended that the recreational use TMDL process be used to evaluate targets not only of bacteria, but sediment and habitat quality.

Ohio Environmental Protection Agency, 2007, Tuscarawas infographic on water-quality conditions, accessed January
25, 2008, at http://www.epa.state.oh.us/dsw/documents/ TuscInfograph2007.pdf

Ohio Environmental Protection Agency, 2009a, Ohio 2008 Integrated Water Quality Monitoring and Assessment Report, accessed January 28, 2009, at http://www.epa.state. oh.us/dsw/tmdl/2008IntReport/2008OhioIntegratedReport. html

Ohio Environmental Protection Agency, 2009b, Source water protection efforts by public water systems in Ohio, accessed January 24, 2009, at http://www.epa.state.oh.us/ddagw/pdu/ swap_protection.html

Ohio Environmental Protection Agency, 2009c, The Nimishillen Creek Watershed TMDL, accessed September 24, 2009 at http://www.epa.ohio.gov/dsw/tmdl/ NimishillenCreekTMDL.aspx

Ohio Environmental Protection Agency, 2009d, The Tuscarawas River Watershed TMDL, accessed February 10, 2009, at http://www.epa.state.oh.us/dsw/tmdl/ TuscarawasRiverTMDL.html

Ohio History Central, 2008, Clay and shale: accessed January 18, 2008, at http://www.ohiohistorycentral.org/

Ohio River Valley Ecosystem Team, 2002a, Status assessment report for the rayed bean, Villosa fabalis, occurring in the Mississippi River and Great Lakes systems (U.S. Fish and Wildlife Service Regions 3,4, and 5, and Canada): U.S. Fish and Wildlife Service, 62 p., accessed September 27, 2006, at http://www.fws.gov/midwest/Endangered/clams/rayedbean-sa.pdf

Ohio River Valley Ecosystem Team, 2002b, Status assessment report for the sheepnose, Plethobasus cyphyus, occurring in the Mississippi River system (U.S. Fish and Wildlife Service Regions 3,4, and 5): U.S. Fish and Wildlife Service, 79 p., accessed September 27, 2006, at http://www.fws.gov/ midwest/Endangered/clams/sheepnose-sa.pdf

Ohio River Valley Water Sanitation Commission, 1951, Brine contamination in the Muskingum River: Cincinnati, Ohio, The Commission, $26 \mathrm{p}$.

Ohio State University Extension, 2006, Watershed Groups in Ohio, accessed September 20, 2006, at http://ohiowatersheds.osu.edu/groups/wgp_all.php

This web page lists watershed groups in Ohio.

Ohio Water Commission, 1960, Public hearing on development of underground water supplies in the Sugar Creek area, Tuscarawas County: Columbus, Ohio, Ohio Water Commission, $66 \mathrm{p}$.

This is a transcript of a hearing to allow the City of Canton to develop a well field in the Sugar Creek Valley. The Ohio Water Commission approved the plan with pumping not to 
exceed $20 \mathrm{Mgal} / \mathrm{d}$. It was recommended that the Department of Natural Resources Division of Water carry out plans to instrument the well field and maintain continuous observation of changes.

Olive, J.H., and Higgins, G., 1981, Algal bioassay of the Portage Lakes, Summit County, Ohio: Environmental Pollution Series A, v. 26, no. 1, p. 59-67.

The Portage Lakes are natural lakes and man-made reservoirs in the upper Tuscarawas River of northeastern Ohio. Algal bioassays were used to determine the effects of phosphate and nitrate enrichment on the algal growth potential in the lakes and to predict the effects of diverting algal nutrients from one part of the lake system to another area within the system.

Omernik, J.M., 1987, Ecoregions of the conterminous United States: Annals of the Association of American Geographers, v. 77 , n. 1, p. 118-125, map scale 1:7,500,000.

Ondecko, J.D., and Schultz, T.J., 1981, Land capability analysis in Portage County, Ohio: Columbus, Ohio, Ohio Department of Natural Resources, Resource Analysis Section, $49 \mathrm{p}$.

Opatrny, J.C., and Larlham, R.C., 1985, Lime Lake Reclamation via Sludge Management: Toxic and Hazardous Wastes: Toxic and Hazardous Wastes-Proceedings of the Seventeenth Mid-Atlantic Industrial Waste Conference, June 23-25, 1985 Technomic Publishing Co. Inc., Lancaster, Pa., $857 \mathrm{p}$.

PPG Industries, Inc., intended to reclaim approximately 600 acres of Solvay Soda Ash Process Waste (Lime Lakes) south of Barberton, Ohio, by incorporating dewatered municipal sludge into the material, recontouring the Lime Lakes with the mixture, and planting them to forest and grassland.

Orton, E., Jr., and Peppel, S.V., 1906, The limestone resources and the lime industry in Ohio: Ohio Department of Natural Resources Bulletin 4, $365 \mathrm{p}$.

Ohio River Valley Ecosystem Team, 1966, The Precambrian surface of Ohio: Ohio Department of Natural Resources Report of Investigation 64, 9 p.

Ohio River Valley Ecosystem Team, 1970, The subsurface Silurian-Devonian "Big Lime" of Ohio: Ohio Department of Natural Resources Report of Investigation 75, 17 p.

Parker, J., and Webb, R., 2006, The Sugar Creek Watershed community restoration project, accessed September 20, 2006, at http://www.bright.net/ swcd/h2osheds/Webpercent 20page/319percent20Grant.htm

The Sugar Creek watershed has a substantial number of home septic systems operating at less than full function plus intensive agricultural activity occurring on highly erodible land. This has led to (1) the loss of stream buffer areas and habitat (particularly on smaller tributaries); (2) stream nutrient loading from erosion, tile flow, and groundwater recharge; and (3) excessive pathogen loadings from both human and animal sources. With an Ohio EPA 319 grant, watershed activists were implementing best management practices, including livestock fencing, riparian buffers, conservation tillage, and waste utilization.

Pavey, R.R., Goldthwait, R.P., Brockman, C.S., Hull, D.N., Swinford, M.E., and Van Horn, Robert G., 1999, Quaternary geology of Ohio: Ohio Department of Natural Resources, Division of Geological Survey, Map 2, scale 1:500,000.

This glacial map of Ohio replaces and updates previous glacial maps of Ohio. The full-color map, at a scale of 1:500,000, shows and describes 44 units of Holocene, Late Wisconsinan, Illinoian, and pre-Illinoian age.

Peattie, R., 1923, Geography of Ohio: Ohio Department of Natural Resources Bulletin 27, 137 p.

Pepper, J.F., 1947, Areal extent and thickness of the salt deposits of Ohio: Ohio Department of Natural Resources Report of Investigation 3, 15 p. (Reprinted from Ohio Journal of Science, 1947 , v. 47, p. 225-239.)

Plummer, L.N., Busenberg, E., Böhlke, J.K., Nelms, D.L., Michel, R.L., and Schlosser, P., 2001, Groundwater residence times in Shenandoah National Park, Blue Ridge Mountains, Virginia, USA: A multi-tracer approach: Chemical Geology, v. 179, nos. 1-4, p. 93-111.

Plummer, L.N., Bohkle, J.K., and Busenberg, Eurybiades, 2003, Approaches for ground-water dating, in Lindsey, B.D., Phillips, S.W., Donnelly, C.A., Speiran, G.K., Plummer, L.N., Böhlke, J.K., Focazio, M.J., Burton, W.C., and Busenberg, Eurybiades, Residence times and nitrate transport in ground water discharging to streams in the Chesapeake Bay Watershed: U.S. Geological Survey WaterResources Investigations Report 03-4035, p. 12-24.

Potter, W.D., 1961, Peak rates of runoff from small watersheds: HDS2: U.S. Department of Transportation, Federal Highway Administration, 64 p., accessed December 13, 2006, at http://www.fhwa.dot.gov/engineering/hydraulics/ pubs/hds2peak.pdf

Prasad, V., Ortiz, A., Stinner, B., McCartney, D., Parker, J., Hudgins, D., Hoy, C., and Moore, R., 2005, Exploring the relationship between hydrologic parameters and nutrient loads using digital elevation model and GIS - A case study from Sugarcreek Headwaters, Ohio, USA: Environmental Monitoring and Assessment, v. 110, p. 141-169.

Spatial distribution of slope (S), altitude, and wetness index along with other watershed characteristics, such as flow direction, flow accumulation, stream networks, flow stream orders, and erosion index, were used within a GIS 
framework to quantify variation in nitrate and phosphate loads to headwater streams. Atmospheric deposition through precipitation could explain approximately 35 percent of total nitrate levels observed in streams. Among the different topographic variables and hydrological indices, results from the step-wise multiple regression indicated the following best predictors for nutrients: (1) elevation range and upstream flow length for nitrate, (2) flow direction and upstream flow length for ammonia-nitrogen and slope, and (3) elevation range for phosphate levels. Differences in the landscape models observed for nitrate, phosphate, and ammonia-nitrogen in the surface waters were attributed partly to differences in the chemical activity and source strengths of the different forms of these nutrients through agricultural management practices. The results identify geomorphologic and landscape characteristics that affect contaminant levels in the study area.

Prée, H.L., 1962a, A part of the Walhonding River basin: Ohio Department of Natural Resources, Ohio water plan inventory: Columbus, Ohio, River Basin Ground-Water Resource Map P-4.

Prée, H.L., 1962b, Sandy Creek basin-underground water resources: Ohio Department of Natural Resources, Ohio Water Plan Inventory File Index P-7, scale 1:125,000.

This map report includes text, a generalized stratigraphic sequence, and water-quality data from 7 wells along Sandy Creek. Water-quality data lists iron concentrations from .03-1.2 ppm, chloride from 2 to $25 \mathrm{ppm}$, total dissolved solids from 195 to $556 \mathrm{ppm}$, hardness from 139 to $467 \mathrm{ppm}$, and $\mathrm{pH}$ from 7.2-7.8. The report includes a map of aquifer yields revealing that most of the area is underlain by sandstone and interbedded shale with yields of 5 to $25 \mathrm{gal} / \mathrm{min}$. The buried valley along Nimishillen Creek in the vicinity of Canton yields $1,000 \mathrm{gal} / \mathrm{min}$ or more to wells.

Prée, H.L., 1962c, Upper Killbuck Creek basin: Ohio Department of Natural Resources, Ohio water plan inventory: Columbus, Ohio, River Basin Ground-Water Resource Map P-3

Preston, M.B., 1987, Quantitative geomorphology and hydrology of Chippewa Creek basin, Cuyahoga County, Ohio: Akron, Ohio, University of Akron, M.S. thesis, 76 p.

Prosser, C.S., 1912, The Devonian and Mississippian formations of northeastern Ohio: Ohio Department of Natural Resources Bulletin 15, 574 p.

Quilliam, R.E., 1973, The Chippewa Creek Watershed project: Wayne, Medina, Summit, and Stark Counties, Ohio: Final environmental statement: U.S. Soil Conservation Service, variously paginated.

Raab, J.M., 2005, Potentiometric surface of the unconsolidated aquifers in Portage County: Ohio Department of Natu- ral Resources, Division of Water, accessed February 15, 2008, at http://www.dnr.state.oh.us/portals/7/gwpsurfacel PSurfPDFs/PortageSG_PSurf.pdf

This map shows potentiometric contours of water levels in the unconsolidated (sand and gravel) aquifers of Portage County created from data collected over a 50 -yr period with a variable contour interval from 25 to $50 \mathrm{ft}$.

Raab, J.M., 2006, Potentiometric surface of the unconsolidated aquifers in Tuscarawas County: Ohio Department of Natural Resources, Division of Water, accessed February 15, 2008, at http://www.dnr.state.oh.us/portals/7/gwpsurface/ PSurfPDFs/TuscarawasSG_Psurf.pdf

This map shows potentiometric contours of water levels in the unconsolidated (sand and gravel) aquifers of Tuscarawas County created from data collected over a 50 -year period with a contour interval from $25 \mathrm{ft}$.

Raab, J.M., and Barrett, K., 2005, Potentiometric surface of the consolidated aquifers in Portage County: Ohio Department of Natural Resources, Division of Water, accessed February 15, 2008, at http://www.dnr.state.oh.us/portals/7/ gwpsurface/PSurfPDFs/PortageBedPSurf.pdf

This map shows potentiometric contours of water levels in the consolidated (bedrock) aquifers of Portage County created from data collected over a 50 -year period with a contour interval of $50 \mathrm{ft}$.

Raab, J.M., and Sprowls, K., 2006, Potentiometric surface of the consolidated aquifers in Harrison County: Ohio Department of Natural Resources, Division of Water, accessed on February 15, 2008 at http://www.dnr.state.oh.us/portals/7/ gwpsurface/PSurfPDFs/HarrisonBed_PSurf.pdf

This map shows potentiometric contours of water levels in the consolidated (bedrock) aquifers of Harrison County created from data collected over a 50-year period with a contour interval of $50 \mathrm{ft}$.

Rashid, A., Aziz, A., and Wong, K.V., 1992, Computer-aided modeling of heterogeneous, two-dimensional, groundwater system: Computers \& Geosciences, v. 18, no. 9, p. 11851194 ,

Rau, J.L., 1969, Hydrogeology of the Berea and Cussewago Sandstones in northeastern Ohio: U.S. Geological Survey Hydrologic Investigations Atlas HA-341, 2 sheets, scale 1:250,000.

This report shows the availability and quality of water in the Berea and Cussewago Sandstones within the northern-most part of Tuscarawas River Basin. Additional data include average reported well yields and average transmissibility, by county. The groundwater contribution to streamflow is described, as well as recharge areas. The approximate position of the freshwater/saltwater interface is shown, plus the thickness and structure of the two units. 
The average transmissivity of the Berea Sandstone is $2,400 \mathrm{gal} / \mathrm{d} / \mathrm{ft}$. Locally, the transmissivity is lower where the sandstone thins, but higher where it is fractured. Favorable areas of recharge are shown in northern parts of Summit and Portage Counties and occur primarily along streams and the Cuyahoga River.

Rau, J.L., 1972, Chloride contamination of ground water at Massillon, Ohio: Abstracts with Programs - Geological Society of America, v. 4, no. 7, p. 633.

By-products of an industrial glass manufacturer in Barberton, Ohio, resulted in concentrations of chloride which ranged from 1,000 to $5,000 \mathrm{mg} / \mathrm{L}$ in the upper Tuscarawas River. A shallow sand and gravel aquifer developed as a public supply for Massillon induced river water, causing a steady increase in concentration of chloride in the raw water of the Ohio Water Services Company. Chloride persisted in the river many miles downstream where concentrations of $980 \mathrm{mg} / \mathrm{L}$ were present during low flow at Newcomerstown. High chloride levels continued below Coshocton where the Muskingum River, fed by the Tuscarawas and Walhonding rivers, still contained chloride concentrations of $580 \mathrm{mg} / \mathrm{L}$. As a result of continued public pressure and new state water-quality standards, the soda ash operation at Barberton will cease in 1977.

Rau, J.L., 1974, Effects of brining and salt by-products operations on the surface and ground water resources of the Muskingum Basin, Ohio, in Coogan, A.H., ed., Fourth symposium on Salt, volume one; Environment: Cleveland, Ohio, Northern Ohio Geological Society, Inc., p. 367-386.

Soda operations of Pittsburgh Plate Glass in Barberton were a major contributor of dissolved solids, especially chloride. Discharges at Clinton affected water quality far downstream. As a result, the Barberton Municipal Wellfield was abandoned in 1926. The Massillon Well Field was seriously affected in 1952 and 1953, and relocated in 1955. Brine contamination forced abandonment of a well field in Coshocton in 1953 and the new wellfield cost about $\$ 500,000$. In 1953, chloride concentrations were as high as $10,050 \mathrm{mg} / \mathrm{L}$. Soda ash operations ceased in 1973. Ohio Department of Health data show concentrations of chloride at Tuscarawas River at Massillon of $2,970 \mathrm{mg} / \mathrm{L}$ and the Tuscarawas River at Newcomerstown of 965 in $\mathrm{mg} / \mathrm{L}$.

Razem, A.C., and Sedam, A.C., 1985, Ground-water quality and geochemistry of aquifers associated with coal in the Allegheny and Monongahela formations, southeastern Ohio: U.S. Geological Survey Water-Resources Investigations Report 85-4034, 39 p.

Groundwater samples were obtained from domestic-supply wells throughout the region. Water type was predominantly calcium-magnesium bicarbonate type, and sodium bicarbonate type was less common. The water was typically very hard. The northern part of study area is bounded by the northern boundary of Tuscarawas, Carroll, and Jefferson Counties. Only a few sites yielded water with a dissolved solids concentration of more than $1,000 \mathrm{mg} / \mathrm{L}$, which could be attributed to oil and gas drilling or road salt, mining activity (high sulfates, iron, and manganese), agricultural or domestic wastes, or natural deposits.

Reich, C., Halley, R.B., Hickey T., and Swarzenski, P., 2006, Groundwater characterization and assessment of contaminants in marine areas of Biscayne National Park: National Park Service Technical Report NPS/NRWRD/NRTR2006/356, accessed on November 27, 2007 at http://sofia. usgs.gov/publications/reports/bisc_gw_char/index.html

This report documents contamination of water-quality samples with DEET, a commonly used insect repellant.

Richards, R.P., and Wallrabenstein, L., 1995, Well water quality in the alluvial deposits along the Tuscarawas and Muskingum Rivers - Final report: Water Quality Laboratory, Heidelberg College, no. 17, 62 p.

This report summarizes analyses of groundwater in the Tuscarawas and Muskingum River alluvium for chloride, nitrate, herbicides, and metals. Concentrations of nitrate were higher along streams than within the counties as a whole. Average concentration of nitrate in ground water in Coshocton County was $6.61 \mathrm{mg} / \mathrm{L}$ with 25 percent of the samples exceeding $10 \mathrm{mg} / \mathrm{L}$ (average concentration was $4.99 \mathrm{mg} / \mathrm{L}$ ). The average nitrate concentration in Tuscarawas County was $11.1 \mathrm{mg} / \mathrm{L}$. Samples from five wells in Tuscarawas County had chloride concentrations in excess of $1,000 \mathrm{mg} / \mathrm{L}$. These same five wells also had the highest concentrations of ammonia, sodium, barium, and strontium and the lowest concentrations of sulfate compared to other samples obtained in the study, indicating a local influence of septic tank effluent from homes that use water softening. Volatile organic compounds were detected infrequently, and detections of herbicides were rare. For herbicides, there were only two atrazine and one alaclor detections.

Riley, R.A., Baranoski, M.T., Wickstrom, L.H., Wells, J.G., and Powers, D.M., 2004, Oil and gas fields map of Ohio: Ohio Department of Natural Resources, Division of Geological Survey, Map PG-1, scale 1:500,000, including text and eight maps.

Risser, M.L., 1976, Bedrock topography of Medina County, Ohio: Ohio Department of Natural Resources, Division of Geological Survey, Open File Map 219, scale 1:63,360.

Risser, M.L., 1981, Sand and gravel resources of Medina County, Ohio: Ohio Department of Natural Resources, Division of Geological Survey, Report of Investigations 119, scale 1:63,360.

This map shows the extent of outwash, kames and eskers, and alluvium; the location of sand and gravel pits; estimates of available sand and gravel resources (in tons) by 
township; sieve analyses; pebble counts; and stratigraphic sections from several water-well logs and measured sections. Kames and outwash are the primary source of an estimated 1.5 billion tons of sand and gravel. This would be an important source of building materials if the projected population from 1970 to 2000 proves to be 75 percent.

Risser, M.L., 1983a, Bedrock topography of Portage County, Ohio: Ohio Department of Natural Resources, Division of Geological Survey, Open File Map 204, scale 1:63,360.

This map was unchecked and unedited and was intended only for preliminary use. The top of bedrock in the Tuscarawas River Basin in Portage County is 900 to $1,100 \mathrm{ft}$.

Risser, M.L., 1983b, Drift thickness map of Portage County, Ohio: Ohio Department of Natural Resources, Division of Geological Survey, Open File Map 205, scale 1:62,500.

This map is on a topographic base at a scale of $1: 62,500$ showing thickness contours of the unconsolidated glacial deposits. This map is superseded by the 1:24,000-scale bedrock-topography maps. It was unchecked and unedited and was intended only for preliminary use. Drift thickness in the Tuscarawas River Basin in Portage County is less than $20 \mathrm{ft}$ up to $200 \mathrm{ft}$ thick.

Risser, M.L., 1986, Sand and gravel resources of Columbiana County, Ohio: Ohio Department of Natural Resources, Division of Geological Survey, Report of Investigations 131, 1 sheet, scale 1:63,360.

The western 1/10th of this map falls within the Tuscarawas watershed. The map shows sand and gravel deposits, pit mine locations, stratigraphy from about 25 well logs in the Tuscarawas River Watershed, plus some grain-size analyses and pebble counts identified by rock type.

Risser, M.L., 1987, Surficial materials of Medina County, Ohio: Ohio Department of Natural Resources, Division of Geological Survey, Report of Investigations 133, scale $1: 63,360$.

This map shows the surficial materials within the upper $25 \mathrm{ft}$ below land surface to be mostly of glacial origin. The map also includes a table of grain size analyses and engineering properties, such as Atterberg limits (liquid and plastic limit), the plasticity index, color, permeability, and shrink-swell potential of tills. Most of Medina County is blanketed by till.

Rizzo, J.S., 1993, Hydrogeology of River Styx Basin, Medina and Wayne Counties, Ohio: Akron, Ohio, University of Akron, M.S. thesis, 197 p.

The average thickness of outwash in the River Styx valley is $450 \mathrm{ft}$. Streams in the basin lose a substantial amount of water as they flow across permeable sands and gravels of the valley fill. Water is initially discharged at the contact between the Sharon Sandston /Conglomerate and the Wooster Shale. Recharge occurs as the streams flow across more porous rock of the Armstrong Siltstone and Rittman Sandstone. Groundwater is transferred to outwash of the valley fill by the Rittman sandstone. Outwash is also recharged by stream loss where streams flow over permeable sands and gravels.

Rogge, W.F., Hildemann, L.M., Mazurek, M.A., Cass, G.R., 1993, Sources of fine organic aerosol: Road dust, tire debris, and organometallic brake lining dust: roads as sources and sinks: Environmental Science and Technology, v. 27, $1892 \mathrm{p}$.

Schaefer, E.J., White, G.W., and Van Tuyl, D.W., 1946, The ground water resources of the glacial deposits in the vicinity of Canton, Ohio: Ohio Department of Natural Resources, Division of Water, Bulletin 3, 60 p.

During 1944, $38 \mathrm{Mgal} / \mathrm{d}$ of groundwater was pumped by the city and its industries: $7 \mathrm{Mgal} / \mathrm{d}$ from bedrock aquifers and $31 \mathrm{Mgal} / \mathrm{d}$ from glacial aquifers. Approximately $19 \mathrm{Mgal} / \mathrm{d}$ was pumped from sand and gravel within city limits, and $11.9 \mathrm{Mgal} / \mathrm{d}$ was from northeast and Grovemiller well fields. Recharge in the area is received mainly in the first 6 months of each year from direct precipitation, from flood waters of Nimishillen creek, and from direct infiltration from Nimishillen Creek. It was estimated that, from 1939-1945, pumping in Canton proper exceeded recharge by about $3.5 \mathrm{Mgal} / \mathrm{d}$. This report also includes detailed maps showing glacial geology, the location of wellfields, and a description of an aquifer test at Sippo. Estimated yield at the Sippo area was 3.5 to $4 \mathrm{Mgal} / \mathrm{d}$.

Schlosser, P., Stute, M., Dorr, H., Sonntag, C., and Munnich, K.O., 1988, Tritium $/{ }^{3} \mathrm{He}$ dating of shallow groundwater: Earth and Planetary Science Letters 89, no. 3/4, p. 353-362.

Schlosser, P., Stute, M., Sonntag, C., and Munnich, K.O., 1989, Tritiogenic ${ }^{3} \mathrm{He}$ in shallow groundwater: Earth and Planetary Science Letters 94, no. 3/4, p. 245-256.

Schmidt, J.J., 1962a, Conotton Creek basin underground water resources: Ohio Department of Natural Resources, Ohio Water Plan Inventory File Index Sheet P-8, scale 1:125,000.

This report contains a single plate with results of analyses of constituents in two groundwater samples. Elevated iron concentrations were only noted in samples from wells screened in sandstone. Concentrations of dissolved iron were 0.3 and $2.7 \mathrm{mg} / \mathrm{L}$; chloride, 7 and $155 \mathrm{mg} / \mathrm{L}$; total dissolved solids, 245 and $83 \mathrm{mg} / \mathrm{L}$; hardness, 156 and $56 \mathrm{mg} / \mathrm{L}$ as $\mathrm{CaCO}_{3}$; and $\mathrm{pH}, 7.1$ and 8.5. The map is colored orange on the east part of the basin, delineating an area where well yields are generally less than $5 \mathrm{gal} / \mathrm{min}$, and green on the west, where wells yields may range from 5 to $25 \mathrm{gal} / \mathrm{min}$.

Schmidt, J.J., 1962b, Middle Tuscarawas River and Sugar Creek basins underground water resources: Ohio Depart- 
ment of Natural Resources, Division of Water, Ohio Water Plan Inventory File Index Sheet P-5, scale 1:125,000.

This is a single plate with some general water-quality data and well yields. Iron concentrations in water from sandstone ranged from 0.3 to $1 \mathrm{mg} / \mathrm{L}$. Iron in water samples from sand and gravel ranged from 0.2 to $0.5 \mathrm{mg} / \mathrm{L}$. Concentrations of chloride ranged from 5 to $650 \mathrm{mg} / \mathrm{L}$ in water samples from sandstone and from 5 to $8 \mathrm{mg} / \mathrm{L}$ in samples from sand and gravel. Concentrations of total dissolved solids ranged from 271 to $1,623 \mathrm{mg} / \mathrm{L}$ in samples from sandstone and from 337 to $391 \mathrm{mg} / \mathrm{L}$ in samples from sand and gravel. Hardness in water samples from sandstone ranged from 22 to $210 \mathrm{mg} / \mathrm{L}$ as $\mathrm{CaCO}_{3}$ and from 200 to $280 \mathrm{mg} / \mathrm{L}$ in samples from sand and gravel. The $\mathrm{pH}$ of groundwater ranged from 7.2 to 8.6 in samples from sandstone and 7.6 to 7.9 in samples from sand and gravel. Most of the map is colored green, which indicates average well yields of 1 to $30 \mathrm{gal} / \mathrm{min}$. The wells completed in valley fill along the Tuscarawas River have a potential yield of greater than $1,000 \mathrm{gal} / \mathrm{min}$.

Schmidt, J.J., 1978, Ground water resources of Medina County: Ohio Department of Natural Resources, Division of Water, scale 1:63,000.

Schmidt, J.J., 1994 (rev.), Ground water resources of Summit County: Ohio Department of Natural Resources, Division of Water, scale 1:63,000.

This is a groundwater-resources map showing shaded areas, indicating well yields. Most of the eastern part of Summit County is yellow where the Sharon Conglomerate yields, on average, $50 \mathrm{gal} / \mathrm{min}$. The western part of the county is underlain by the Cuyahoga Formation (in brown) with average yields ranging from 3 to $10 \mathrm{gal} / \mathrm{min}$. Isolated areas within the valleys may yield more than $100 \mathrm{gal} / \mathrm{min}$.

Schmidt, J.J., and Ohio Dept. of Natural Resources, 1959, Little Muskingum River and Duck Creek basins: Ohio Department of Natural Resources: Columbus, Ohio, River Basin Ground-Water Resource Map R-1 and R-2.

Schmidt, J.J., and Ohio Dept. of Natural Resources, 1962a, Middle Tuscarawas River and Sugar Creek basins: Ohio Department of Natural Resources: Columbus, Ohio, River Basin Ground-Water Resource Map P-5.

Schmidt, J.J., and Ohio Dept. of Natural Resources, 1962b, Part of upper portion of the Muskingum River basin: Ohio Department of Natural Resources: Columbus, Ohio, River Basin Ground-Water Resource Map P-11.

Schmidt, J.J., and Walker, A.C., 1954, The ground-water resources of the areas in the vicinity of the interchanges on the east-west Ohio Turnpike: Ohio Department of Natural Resources, Division of Water Information Circular 5, 65 p.

Schumacher, S.D., Boone, K.M., and Brown, L.C., undated a, Belmont County water resources: Ohio State University
Extension Fact Sheet AEX-480.07, accessed November 11, 2006, at http://ohioline.osu.edu/aex-fact/0480_07.html

Overview of Belmont County's water resources, including precipitation, groundwater, surface water, water use, and water quality. Average rainfall for Belmont County was 43 inches per year, providing 11 inches per year of runoff to streams and lakes. About 7 inches per year had the potential to recharge aquifers. Land use was 79 percent farmland.

Schumacher, S.D., Jones, W.A., Brown, L.C., and Boone, K.M., undated b, Belmont County ground-water resources: Ohio State University Extension Fact Sheet AEX-490.07, accessed November 20, 2006, at http://ohioline.osu.edu/ aex-fact/0490_07.html

This is an overview of Belmont County's groundwater resources, including definitions of aquifer and well yield. Ohio Department of Natural Resources observation wells and chemical analysis sites are shown on a generalized map of well yields. The most productive wells are found in sand and gravel deposits along the Ohio River.

Sedam, A.C., 1973, Hydrogeology of the Pottsville formation in northeastern Ohio: U.S. Geological Survey, U.S. Geological Survey Hydrologic Investigations Atlas HA-494, 2 sheets, scale 1:500,000 and 1:250,000.

This report contains two plates showing the extent of the Pottsville Formation, along with the yield of the aquifer and water-quality data. Most of the water is hard and contains elevated iron concentrations.

Sedam, A.C., 1991, Geologic setting and water quality of selected basins in the active coal-mining areas of Ohio, 1987-88: U.S. Geological Survey Water-Resources Investigations Report 90-4109, $97 \mathrm{p}$.

Hydrologic data were collected from selected drainage basins in the active coal-mining areas of Ohio from July 1987 through October 1988. The data-collection network consisted of 41 long-term surface-water sites in 21 basins. Sampling focused on tributaries to the Tuscarawas River, not the Tuscarawas River itself. Results of chemical analyses of 202 surface-water and 24 groundwater samples are presented. For field measurements made at surfacewater sites, the specific conductance ranged from 295 to $3,150 \mu \mathrm{S} / \mathrm{cm}, \mathrm{pH}$ ranged from 2.8 to 8.6 , and alkalinity ranged from 5 to $305 \mathrm{mg} / \mathrm{L}$ as $\mathrm{CaCO}_{3}$.

Sedam, A.C., and Francy, D.S., 1993, Geologic setting and water quality of selected basins in the active coal-mining areas of Ohio, 1989-91, with a summary of water quality for 1985-91: U.S. Geological Survey Water-Resources Investigations Report 93-4094, 133 p.

This report includes data from Sedam (1991) summarizing long-term data collected over 7 years. Median values in surface water for specific conductance were $792 \mu \mathrm{S} / \mathrm{cm}$; 
$\mathrm{pH}, 7.8$; alkalinity, $116 \mathrm{mg} / \mathrm{L}$ as $\mathrm{CaCO}_{3}$; acidity, $118 \mathrm{mg} / \mathrm{L}$ as $\mathrm{CaCO}_{3}$; sulfate, $200 \mathrm{mg} / \mathrm{L}$; aluminum, $30 \mu \mathrm{g} / \mathrm{L}$; iron, $60 \mu \mathrm{g} / \mathrm{L}$; and manganese, $29 \mu \mathrm{g} / \mathrm{L}$. For groundwater samples, the median specific conductance was $650 \mu \mathrm{S} / \mathrm{cm}$; $\mathrm{pH}, 7.4$; hardness, $292 \mathrm{mg} / \mathrm{L}$; alkalinity $229 \mathrm{mg} / \mathrm{L}$ as $\mathrm{CaCO}_{3}$; sulfate, $48 \mathrm{mg} / \mathrm{L}$; aluminum, less than $10 \mu \mathrm{g} / \mathrm{L}$; iron, $275 \mu \mathrm{g} / \mathrm{L}$; and manganese, $59 \mu \mathrm{g} / \mathrm{L}$.

Sedam, A.C., and Stein, R.B., 1970, Saline ground-water resources of Ohio: U.S. Geological Survey Hydrologic Investigations Atlas HA-366, 2 sheets, scale 1:500,000.

This is an assessment of saline aquifers as possible sources of fresh water through desalinization. It also mentions limiting the use of saline aquifers as disposal sites for liquid wastes. The report includes contour maps showing the "approximate base of potable water" and lists the rock unit containing the lowermost zone of potable water.

For most of the Tuscarawas River Basin, the Pennsylvanian units contain the lowermost zone of potable water. In most of Harrison and Guernsey Counties and in the southeastern part of Carroll County, the lowermost potable zone is in the Freeport Sandstone Member of the Allegheny Formation. Elsewhere, the lowermost potable water is obtained from the Pottsville Formation. In central Carroll County, it is in the Homewood Sandstone Member of the Pottsville Formation. In most of Tuscarawas County and the eastern part of Coshocton County, the lowermost potable water can be found in the Connoquenessing Sandstone Member of the Pottsville Formation. The Sharon Conglomerate Member of the Pottsville Formation is the lowermost potable zone in parts of Stark and Portage Counties. In the western part of the Tuscarawas Basin, the lowermost zones of potable water are found in the Black Hand Sandstone and approximate equivalents of the Cuyahoga Group (Mississippian). Results of chemical analyses of water collected near the base of the potable zone are presented.

Shearrow, G.G., 1957, Geologic cross section of the Paleozoic rocks from northwestern to southeastern Ohio: Ohio Department of Natural Resources Report of Investigation 33, 42 p.

Slucher, E.L., 2004, Generalized column of bedrock units in Ohio: Ohio Department of Natural Resources, Division of Geological Survey [oversize sheet].

Slucher, E.R., Swinford, E.M., Larsen, G.E., Schumacher, G.A., Shrake, D.L., Rice, C.L., Caudill, M.R., and Rea, R.G., 2006, Bedrock geologic map of Ohio: Ohio Department of Natural Resources, Division of Geological Survey, Map BG-1, version 6, scale 1:500,000.

Smith, B.E., 1969, Bedrock geology of the Caldwell North quadrangle, Guernsey and Noble Counties, Ohio: Ohio Department of Natural Resources Report of Investigation 72 , one sheet with text.
Smith, R.C., and White, G.W., 1953, The ground-water resources of Summit County, Ohio: Ohio Department of Natural Resources, Division of Water Bulletin 27, 130 p.

This is a report on the groundwater resources in Summit County, including the cities of Barberton and Akron. Favorable groundwater development areas are primarily in southern Summit County along the Tuscarawas River. The census of 1945 reported land use as 48.3 percent agriculture with a population of 410,032 . Table 1 shows industrial groundwater usage is dominated by Firestone at $6.3 \mathrm{Mgal} / \mathrm{d}$, Goodyear at $4.5 \mathrm{Mgal} / \mathrm{d}$, and Goodrich at $4.3 \mathrm{Mgal} / \mathrm{d}$.

Smith, W.H., 1949 (reprinted 1968), Sand and gravel resources in northern Ohio: Ohio Department of Natural Resources, Division of Geological Survey, Report of Investigations 6, $24 \mathrm{p}$.

Somers, W.P., Cross, W.P., and Edelen, G.W., Jr., 1962, Floods at Canton, Ohio: U.S. Geological Survey, Hydrologic Atlas HA-50, 1 sheet, scale 1:24,000.

Spahr, P.N., 1995, Ground water pollution potential of Coshocton County, Ohio: Ohio Department of Natural Resources, Division of Water, Ground Water Pollution Potential Report 32, $74 \mathrm{p}$.

This is a summary of DRASTIC pollution potential indices in Coshocton County, showing relatively low to moderate pollution potentials in upland areas and moderate potential indices in areas adjacent to streams. The buried valley settings are usually the most vulnerable to contamination and have the highest values. Several quarries or strip mines also are shown. The text describes the generalized geology and well yields. The valleys are colored yellow to red, and pollution potential indices ranging from 160 to 179 and 180 to 199 , respectively.

Springer, A.E., 1987, A hydrogeologic evaluation of groundwater resource of Wooster, Ohio: Wooster, Ohio, The College of Wooster, unpublished senior independent-study thesis, $78 \mathrm{p}$.

Sprowls, K., 2005, Potentiometric surface of the consolidated aquifers in Medina County: Ohio Department of Natural Resources, Division of Water, accessed February 15, 2008, at http://www.dnr.state.oh.us/portals/7/gwpsurfacel PSurfPDFs/MedinaBedPSurf.pdf

This map shows potentiometric contours of water levels in the consolidated (bedrock) aquifers of Medina County created from data collected over a 50-year period with a contour interval of $50 \mathrm{ft}$.

Sprowls, K., 2006a, Potentiometric surface of the consolidated aquifers in Wayne County: Ohio Department of Natural Resources, Division of Water, accessed February 15, 2008, at http://www.dnr.state.oh.us/portals/7/gwpsurface/ PSurfPDFs/WayneBedPSurf.pdf 
This map shows potentiometric contours of water levels in the consolidated (bedrock) aquifers of Wayne County created from data collected over a 50 -year period with a variable contour interval of 50 to $100 \mathrm{ft}$.

Sprowls, K., 2006b, Potentiometric surface of the unconsolidated aquifers in Wayne County: Ohio Department of Natural Resources, Division of Water, accessed February 15, 2008, at http://www.dnr.state.oh.us/portals/7/gwpsurface/ PSurfPDFs/WayneSG_PSurf.pdf

This map shows potentiometric contours of water levels in the unconsolidated (sand and gravel) aquifers of Wayne County created from data collected over a 50-year period with a variable contour interval from 50 to $100 \mathrm{ft}$.

Sprowls, K., 2007a, Potentiometric surface of the consolidated aquifers in Columbiana County: Ohio Department of Natural Resources, Division of Water, accessed February 15, 2008, at http://www.dnr.state.oh.us/portals/7/gwpsurfacel PSurfPDFs/ColumbianaBed_Psurf.pdf

This map shows potentiometric contours of water levels in the consolidated (bedrock) aquifers of Columbiana County created from data collected over a 50-year period with a contour interval of $50 \mathrm{ft}$.

Sprowls, K., 2007b, Potentiometric surface of the consolidated aquifers in Summit County: Ohio Department of Natural Resources, Division of Water, accessed on February 15, 2008, at http://www.dnr.state.oh.us/portals/7/gwpsurface/ PSurfPDFs/SummitBed_Psurf.pdf

This map shows potentiometric contours of water levels in the consolidated (bedrock) aquifers of Summit County created from data collected over a 50 -year period with a contour interval of $50 \mathrm{ft}$.

Sprowls, K., 2007c, Potentiometric surface of the consolidated aquifers in Tuscarawas County: Ohio Department of Natural Resources, Division of Water, accessed on February 15, 2008, at http://www.dnr.state.oh.us/portals/7/gwpsurface/ PSurfPDFs/TuscarawasBed_Psurf.pdf

This map shows potentiometric contours of water levels in the consolidated (bedrock) aquifers of Tuscarawas County created from data collected over a 50 -year period with a contour interval of $50 \mathrm{ft}$.

Sprowls, K., and Raab, J.M., 2006, Potentiometric surface of the unconsolidated aquifers in Medina County: Ohio Department of Natural Resources, Division of Water, accessed on February 15, 2008, at http://www.dnr.state. oh.us/portals/7/gwpsurface/PSurfPDFs/MedinaSG_Psurf. $p d f$

This map shows potentiometric contours of water levels in the unconsolidated (sand and gravel) aquifers of Medina County created from data collected over a 50-year period with a contour interval of $50 \mathrm{ft}$.
Sprowls, K., Raab, J.M., and Hallfrisch, M.P., 2007, Potentiometric surface of the unconsolidated aquifers in Summit County: Ohio Department of Natural Resources, Division of Water, accessed February 15, 2008, at http://www.dnr.state. oh.us/portals/7/gwpsurface/PSurfPDFs/SummitSG_Psurf. $p d f$

This map shows potentiometric contours of water levels in the unconsolidated (sand and gravel) aquifers of Summit County created from data collected over a 50-year period with a contour interval of $50 \mathrm{ft}$.

Stafford, F.W., 1954, Study and report on water resources of the Tuscarawas and Nimisila Creek with combined storage facilities of the Portage Lakes and Nimisila Reservoir, Summit County, Ohio: Akron, Ohio, Ohio Department of Public Works, $59 \mathrm{p}$.

This study describes storage and diversion facilities provided by the Nimisila Reservoir. The estimated average daily water supply from the entire system was $16 \mathrm{Mgal} / \mathrm{d}$.

Stamm, J.M., Ricker, K.T., and Brown, L.C., undated, Water resources of Columbiana County: Ohio State University Extension Fact Sheet AEX-480.15-97, accessed November 20, 2006, at http://ohioline.osu.edu/aex-fact/0480_15.html

This is an overview of water resources for Columbiana County, including precipitation, ground water, surface water, water use, and water quality. Average rainfall for the Columbiana County area is 38 inches per year providing 10 inches per year of runoff to streams and lakes. About 6 inches per year have the potential to recharge aquifers. Land use is 29 percent cropland, 17.1 percent pastureland, and 33.5 percent forest land. Nitrate appears to have been an issue in ground water.

Stark County Health Department, 2005, 2005 Annual Report, accessed September 12, 2006, at http://www.starkhealth. org/environmental.htm

This report gives details about a train derailment in Perry Township (1/3 mile west of Kemary Avenue) that spilled acetone, a program to sample industrial waste at the two municipal solid waste facilities, and closure of the Exit C\&D Landfill in Osnaburg Township. Details included as part of the landfill closure stated that the owner accepted solid waste and operated outside the facility's approved plan. Subsurface fires and sinkholes formed soon after.

Stark County Regional Planning Commission, 1997, Stark County 2020 land use plan: Stark County Regional Planning Commission, 72 p., accessed September 27, 2006, at http:// www.co.stark.oh.us/internet/docs/rpc/2020landuseplan.pdf

This plan describes existing transportation corridors, land use, future land use trends, future population trends, and planning for public water, sewers, and open space. In the previous land-use survey completed in 1980, 23.9 percent 
of the land was urban and 76.1 percent non-urban. In 1975, the distribution was 22.6 percent urban land use and 77.4 percent non-urban land use. While the trend was gradually toward greater urbanization in Stark County, this rate of change was relatively slow, and the county had a vast "reservoir" of open land potentially available for future urban development. It was estimated that, in 1994, Stark County had approximately 92,600 acres (25.6 percent) of developed urban land use, and 270,100 acres (74.4 percent) of non-urban land use, such as farm land, strip mines, water, and vacant land.

Stark County Regional Planning Commission and Stark County Area Transportation Study, 2005, Stark County 2030 comprehensive/transportation plan: Executive summary with transportation projects: Stark County Regional Planning Commission, 17 p., accessed September 27, 2006, at http://www.co.stark.oh.us/internet/HOME. DisplayPage?v_page $=r p c \_l r p$

After losing population from 1980 to 1990, Stark County has rebounded slightly in recent years with accompanying economic growth. The 2000 Census lists the county's population at 378,098 (a 2.8 percent increase over 1990). According to the Ohio Department of Development, the county's 2003 population is estimated at 389,174 , an increase of about 2.9 percent over the 2000 figure. Water resources are identified as a major issue. Specific issues related to water resources include stormwater, solid waste disposal, and central sewer and water services.

Stauffer, C.R., 1909, The Middle Devonian of Ohio: Ohio Department of Natural Resources Bulletin 10, 204 p.

Stauffer, C.R., and Schroyer C.R., 1920, The Dunkard series of Ohio: Ohio Department of Natural Resources Bulletin $22,167 \mathrm{p}$.

Stout, W., 1916, Geology of southern Ohio: Ohio Department of Natural Resources Bulletin 20, 723 p.

Stout, W., 1918, Geology of Muskingum County: Ohio Department of Natural Resources Bulletin 21,351 p.

Stout, W., 1929, Generalized section of coal bearing rocks of Ohio: Ohio Department of Natural Resources Information Circular 2, folded chart.

Stout, W., 1940a, Clarion clay of Hope and Lincoln Furnace fields: Ohio Department of Natural Resources Bulletin 40, $48 \mathrm{p}$.

Stout, W., 1940b, Marl, tufa rock, travertine, and bog ore in Ohio: Ohio Department of Natural Resources Bulletin 41, $56 \mathrm{p}$.

Stout, W., 1943, Generalized geologic section of rocks in Ohio: Ohio Department of Natural Resources Information Circular 4, folded chart.
Stout, W., 1944, The iron ore bearing formations of Ohio: Ohio Department of Natural Resources Bulletin 45, 230 p.

Stout, W., 1946, Mineral resources of Ohio: Ohio Department of Natural Resources Information Circular 1, 33 p.

Stout, W., and Lamborn, R.E., 1924, Geology of Columbiana County: Ohio Department of Natural Resources, Division of Geological Survey, Bulletin 28, 408 p.

This report provides detailed descriptions of outcrops and well logs of stratigraphy throughout the county by township. Early history and demographics of the county also are provided.

Stout, W., Lamborn, R.E., and Schaaf, D., 1932, Brines of Ohio: Ohio Department of Natural Resources Bulletin 37, $123 \mathrm{p}$.

Stout, W., and Schoenlaub, R.A., 1945, The occurrence of flint in Ohio: Ohio Department of Natural Resources Bulletin 46, $110 \mathrm{p}$.

Stout, W., Stull, R.T., McCaughey, W.J., and Demorest, D.J., 1923, Coal formation clays of Ohio: Ohio Department of Natural Resources Bulletin 26, 588 p.

Stout, W., Ver Steeg, K., and Lamb, G.F., 1943 (reprinted in 1968), Geology of water in Ohio: Ohio Department of Natural Resources Bulletin 44, 694 p.

Struble, R.A., and Hodges, D.A., 1982, Fracture analysis of Eastern Ohio, in Gray, J.D., Struble, R.A. and Carlton, R.W., and others, eds., An integrated study of the Devonianage black shales in Eastern Ohio: Columbus, Ohio, Ohio Department of Natural Resources, Division of Geological Survey, p. 7.1-7.12.

This report was part of the Eastern Gas Shales Project sponsored by U.S. Department of Energy. Secondary fracture porosity is thought to be essential for commercial gas production from the shale sequence. A structure contour map on top of the Berea Sandstone reflects the general structural configuration of the Appalachian Basin in eastern Ohio. Maps included in the report show LANDSAT interpretation and aerial-photo interpretation with some statistical analysis of fracture density.

Sturgeon, M.T., and Merrill, W.M., 1949, An additional fossiliferous member in the Allegheny formation (Pennsylvanian) of Ohio: Ohio Department of Natural Resources Information Circular 5, 11 p., 3 figs., 1 pl. (Reprinted from Ohio Journal of Science, 1949, v. 49, p. 1-11.)

Stute, M., and Schlosser, P., 1999, Atmospheric noble gases, in Cook, P., and Herczeg, A., eds., Environmental tracers in subsurface hydrology: Boston, Mass., Kluwer Academic Publishers, p. 349-377. 
Sugar, D.J., 1988, Ground-water resources of Coshocton County: Ohio Department of Natural Resources, Division of Water, scale 1:62,500.

This map shows expected well yields over large areas, and, for specific wells, shows the well depth, well yield, waterbearing formation, and depth to bedrock. Yields of greater than $500 \mathrm{gal} / \mathrm{min}$ may be obtained from valley fill deposits of the Tuscarawas River. The upper Mississippian and lower Pennsylvanian sandstones, shales, and limestones in the uplands generally yield less than $10 \mathrm{gal} / \mathrm{min}$.

Summerson, C.H., 1962, Precambrian in Ohio and adjoining areas: Ohio Department of Natural Resources Report of Investigation 44, $16 \mathrm{p}$.

The Nature Conservancy, 2006, Stillfork Swamp, accessed September 21, 2006, at http://www.nature.org/ wherewework/northamerica/states/ohio/preserves/art3097. html

The Stillfork Swamp encompasses more than 600 acres within the Stillfork Valley and its major tributaries. The swamp is drained by Stillfork Creek, a small, slow moving stream characterized by an extremely small gradient. Stillfork Creek flows into Sandy Creek and into the Tuscarawas River. This is one of the most extensive inland marshes in the unglaciated Western Allegheny Plateau Ecoregion of eastern Ohio and contains a diversity of other wetland habitat types. The area has long been recognized for its importance as nesting grounds for a variety of waterfowl and marsh birds.

Times Reporter, 2005, The flood of January 2005, accessed March 11, 2008, at http://www.timesreporter.com/feature/ Jan05 Flood/flood page.htm

Thomas, M.D., 1960, Estimates of water uses in the Muskingum Watershed Conservancy District for 1975: Annals of the Association of American Geographers, v. 50, no. 1, p. 22-41.

Thornthwaite, C.W., 1948, An approach toward a rational classification of climate: Geographic Review, v. 38, p. 55-94.

Timme, P.J., 1995, National Water Quality Laboratory 1995 Services Catalog: U.S. Geological Survey Open-File Report 95-352, p. 92.

Tobin, R.L., and Youger, J.D., 1978, Limnology of selected lakes in Ohio-1975: U.S. Geological Survey WaterResources Investigations Report 77-105, 205 p.

Tobin, R.L., and Youger, J.D., 1979, Chemical and biological quality of selected lakes in Ohio-1976 and 1977: U.S. Geological Survey Water-Resources Investigations Report 78-109, 291 p.

Twenty-eight lakes were sampled by U.S. Geological Survey and Ohio Environmental Protection Agency for field characteristics. Within the Muskingum River Basin, data for Salt Fork Lake, Lake Rockwell, Summit Lake, Mogadore Reservoir, Atwood Lake, Leesville Lake, Tappan Lake, Clendening Lake, Wills Creek Lake, Michael J. Kirwin Reservoir, Long Lake, Turkeyfoot Lake, Nimisila Reservoir, and Piedmont Lake are included.

Lake depth had a major controlling effect on water quality. Lakes less than $17 \mathrm{ft}$ deep do not develop stratification and are generally of poorer quality. Light transparency ranged from $0.75 \mathrm{ft}$ in Stonelick to $21 \mathrm{ft}$ in Mogadore Reservoir. Dissolved oxygen supersaturation was common in euphotic zones, whereas dissolved oxygen depletion occurred in the bottom waters of all thermally stabilized lakes. The 5-day biological oxygen demand ranged from 0.3 to $17 \mathrm{mg} / \mathrm{L}$. Hydrogen sulfide $\left(\mathrm{H}_{2} \mathrm{~S}\right)$ was generated in all sustained anaerobic zones. $\mathrm{pH}$ ranged from 7.1 to 8.5 , and $\mathrm{pH}$ maximums were measured during periods of high photosynthetic activity. Mean $\mathrm{pH}$ change and standard deviation within the water column was $1.4 \pm 0.4$ in the summer. All lakes had moderately hard to very hard water and were characterized as calcium-bicarbonate sulfate type waters. Summit Lake was the only sodium chloride type lake. Specific conductance changed significantly with depth during periods of thermal stratification. Nitrate and phosphorus concentrations were characteristically high in all lakes. Bacteria counts of fecal coliform were less than 2 to 230 colonies per $100 \mathrm{~mL}$ and were highest in Summit Lake and East Branch Reservoir. Phytoplankton densities were high in most lakes. Estimated sediment yields for lakes in the Tuscarawas River Basin were 100 to 200 tons $/ \mathrm{mi}^{2} / \mathrm{yr}$.

Totten, S.M., 1988, Glacial geology of Medina County, Ohio: Ohio Department of Natural Resources, Division of Geological Survey, Report of Investigations 141, 38 p.

This report includes text and a series of maps showing major end moraines, kames and associated gravel quarries, drift thickness, and ancient drainage. It also includes a table of till color, along with engineering properties such as grain-size analyses and Atterberg limits. The report notes that Chippewa Lake is a remnant of a late-glacial lake that used to be $7 \mathrm{mi}$ long.

Tuscarawas County Metropolitan Sewer District, 2006, Wilkshire Hills community water system source water protection plan, accessed September 27, 2006, at $h t t p: / / w w w$. co.tuscarawas.oh.us/Water\&Sewer/SourceWaterProtection. htm

This plan shows wellhead protection zones (1-yr, 5-yr, and $10-\mathrm{yr}$ ) around Wilkshire Hills water system and the relation of the water system to a nearby landfill.

U.S. Army Corps of Engineers, 1935, Specifications for constructing Atwood Dam on Indian Fork, Conotton Creek, near Sherrodsville, Ohio: Zanesville, Ohio, U.S. Engineer Office, Federal Emergency Administration of Public Works, $164 \mathrm{p}$. 
U.S. Army Corps of Engineers, 1943, Report on analysis of hydrologic data for index areas: Muskingum River Basin, Ohio (rev. ed.): Huntington, W. Va., U.S. Army Corps of Engineers, variously paginated.

U.S. Army Corps of Engineers, 1967, Muskingum River basin study: Transcript of public hearing at Zanesville, Ohio, 16 December 1966: Huntington, W. Va., U.S. Army Corps of Engineers, Huntington District, variously paginated.

U.S. Army Corps of Engineers, 1970, Flood plain information: Tuscarawas River, Stark County, Ohio: Huntington, W. Va., U.S. Army Corps of Engineers, Huntington District, 45 p.

U.S. Army Corps of Engineers, 1973, Flood plain information: Tuscarawas River and adjacent tributary areas, Tuscarawas County, Ohio: Huntington, W. Va., U.S. Army Corps of Engineers, Huntington District, $28 \mathrm{p}$.

U.S. Army Corps of Engineers, 1977, Muskingum River basin flood control system, Muskingum River basin, Ohio: Final environmental impact statement: Huntington, W Va., U.S. Army Engineer District, 344 p.

U.S. Army Corps of Engineers, 2006a, Muskingum River Basin Systems Operations Study: Huntington, W. Va., U.S. Army Corps of Engineers, Huntington District, 60 p, accessed September 12, 2006, at http://www. muskingumbasin.org/pdfs/muskingum_river_basin_report_ final_draft_mar06.pdf

The Muskingum River Basin multi-purpose reservoir system consisted of 14 projects originally constructed in the 1930s and two additional projects constructed in 1959 and 1972. Development of this reservoir system was a joint effort of the U.S. Army Corps of Engineers and the Muskingum Watershed Conservancy District. As of 2006, there were major problems associated with the conditions of the structures as well as the physical changes that have occurred in the Muskingum Basin since the projects were constructed. Routine maintenance provided a basis for addressing some of the minor problems, but there was a need for a comprehensive review with public participation of the entire 70 -year old system to understand the varying significant issues and develop an acceptable revitalization plan. The major problems identified in this study were related to aging infrastructure (hydrologic deficiency, seepage and foundation problems, outlet tunnel deterioration, gate deterioration, spillway erosion, relief wells, and appurtenant facilities), reservoirs/lakes problems (reservoir operations, sedimentation and flood storage loss, lake quality, and conflicts among project purposes), and watershed problems (ecosystem degradation, acid mine drainage, residual flood damages, flood plain development, and water and sewer infrastructure needs). A web page that largely summarizes this report is available at http://www.muskingumbasin.org/.
U.S. Army Corps of Engineers, 2006b, Ohio Public Notices, accessed September 20, 2006, at http://www.lrh.usace.army. mil/permits/publicnotices/oh/

This Web page contains notices about permit applications for work or structures in or affecting the course, condition, or capacity of navigable waters, or discharge of dredged and fill material into waters, including wetlands.

U.S. Army Corps of Engineers, 2008, Huntington District water control, accessed April 5, 2008, at http://www.lrh-wc. usace.army.mil/wc/distns.htm

This Web site contains links to descriptions of each lake including location, reason constructed, dam description, stream dammed, photographs, maximum pool elevation, and acreage. Individual lake Web pages include data regarding current pool height/elevation, outflow temperature, and pool height/elevation and precipitation in the last 24 hours.

U.S. Census Bureau, 2008, The 2008 statistical abstract, The National data book, accessed June 18, 2008, at http://www. census.gov/compendia/statab/cats/population.html

U.S. Department of Transportation, 1974, U.S. Route 30 environmental impact study_Project No. U-633 (15)(16)(17), Stark County, Ohio: Columbus, Ohio, Federal Highway Administration and Ohio Department of Transportation, $140 \mathrm{p}$.

Construction along or rerouting of U.S. 30 was not anticipated to have a substantial effect on the water quality of the east and west branches of Nimishillen Creek. The waterquality report indicated that both of these streams were in a degraded, contaminated condition at both crossing points with the relocated U.S. 30. Water-quality analyses for oxygen demand, $\mathrm{pH}$, suspended sediment, turbidity, and dissolved metals are included. Benthic animals indicate contamination prior to the building of U.S. 30 .

U.S. Department of Transportation, 2008, Killbuck Marsh Ohio, National Scenic Byways Program, accessed March 11, 2008, at http://www.byways.org/explore/byways/13793/ places/14237/

U.S. Environmental Protection Agency, 1975a, Report on Atwood Reservoir, Carroll and Tuscarawas Counties, Ohio: EPA Region V: U.S. Environmental Protection Agency, National Eutrophication Survey, Working Paper 393, no. 14, $23 \mathrm{p}$.

U.S. Environmental Protection Agency, 1975b, Report on Beach City Reservoir, Stark and Tuscarawas Counties, Ohio: EPA Region V: U.S. Environmental Protection Agency, National Eutrophication Survey, Working Paper 394 , no. 15,26 p.

U.S. Environmental Protection Agency, 1975c, Report on Tappan Reservoir, Harrison County, Ohio: EPA Region V: 
U.S. Environmental Protection Agency, National Eutrophication Survey, Working Paper 412, 13 p.

U.S. Environmental Protection Agency, 1978, A compendium of lake and reservoir data collected by the National Eutrophication Survey in eastern, north-central, and southeastern United States: U.S. Environmental Protection Agency, National Eutrophication Survey, Working Paper 475, 266 p.

This report provides summary data on morphology (type, drainage area, surface area, mean depth, total inflow, retention time), physical and chemical characteristics (alkalinity, specific conductance, Secchi disk depth, phosphorus, orthophosphate, inorganic nitrate, and total nitrate), biological characteristics (chlorophyll $a$, algae, and phytoplankton), nutrient loadings, and nonpoint source nutrient export for Atwood Reservoir, Beach City Reservoir, and Tappan Reservoir.

U.S. Environmental Protection Agency, 2005, Sole Source Aquifer Protection Program, accessed April 1, 2005, at http://www.epa/gov/safewater/ssanp.html

U.S. Environmental Protection Agency, 2006a, National Assessment Database: Assessment data for Ohio, Tuscarawas Watershed, Year 2002, accessed September 19, 2006, at $h t t p: / / i a s p u b . e p a . g o v / t m d l / w 305 b \_r e p o r t \_v 2 . h u c ? p \_$ $h u c=05040001 \& p$ state $=O H$

This report lists impaired stream segments in 2002, along with the causes of impairment.

U.S. Environmental Protection Agency, 2006b, Surf your watershed: Tuscarawas watershed profile, accessed September 19, 2006, at http://cfpub.epa.gov/surf/huc.cfm?huc code $=05040001$

U.S. Environmental Protection Agency, 2006c, Targeted watersheds grants program: Project summaries, accessed September 19, 2006, at http://www.epa.gov/ twg/2005/2005projsumm.html

This Web page provides background data related to Huff Run, a relatively small, $14.7 \mathrm{mi}^{2}$ watershed, situated in central eastern Ohio. Extensive pre-law coal mining has severely damaged the watershed and subsequently degraded the water quality and aquatic wildlife habitat. Restoration plans include surface reclamation and treatment using passive treatment technologies to remove metals and increase alkalinity. Watershed grant funds will be used to build vertical flow wetlands. This technology uses a series of wetland treatment ponds that have been shown to be effective in removing substantial amounts of aluminum and iron from highly acid waters.

U.S. Environmental Protection Agency, 2008a, Drinking water contaminants, accessed May 22, 2008, at http://www.epa. gov/safewater/contaminants/index.html
U.S. Environmental Protection Agency, 2008b, Latest findings on National air quality status and trends through 2006: U.S. Environmental Protection Agency, Office of Air Quality Planning and Standards, Air Quality Assessment Division, EPA-454/R-07-007.

U.S. Environmental Protection Agency, 2009, Proposed radon in drinking water rule: accessed February 25, 2009 at http://www.epa.gov/ogwdw/radon/fact.html

U.S. Federal Emergency Management Agency, 2006, FEMA Map Service Center: FEMA issued flood maps, accessed December 19, 2006, at http://msc.fema.gov/

Historical and recent flood maps for any community can be viewed online and purchased at this Web site. County kits, having all information for a county, also can be purchased. The general Web site is http://www.fema.gov/.

U.S. Fish and Wildlife Service, 2009a, National Wetlands Inventory, accessed on January 28, 2009, at http://www.fws. gov/wetlands/

U.S. Fish and Wildlife Service, 2009b, Ohio's federally threatened, endangered, proposed and candidate species' county distribution, accessed January 26, 2009, at http://www.fws. gov/midwest/endangered/lists/ohio-spp.htm

This Web site lists endangered species by county and notes their preferred habitat. Within the Tuscarawas River Basin, listed species include the Indiana Bat, the Bald Eagle, the Eastern Massasauga (swamp rattler), several mussel species, Mitchell's Satyr (butterfly), the Eastern Prairie Fringed Orchid, and the Northern Monkshood.

U.S. Geological Survey, 1981, Digital line graphs, accessed August 27, 2008, at http://eros.usgs.gov/products/map/ dlg.php

U.S. Geological Survey, 1997-present, National field manual for the collection of water-quality data: U.S. Geological Survey Techniques of Water-Resources Investigations, book 9, chaps. A1-A9, variously paginated. (Chapters were published and revised from 1997 to present; updates and revisions are ongoing and can be viewed at $h t t p: / / w a t e r$. usgs.gov/owq/Fieldprocedures.html)

U.S. Geological Survey, 1998, U.S. Geological Survey Digital Raster Graphic, accessed March 19, 2009, at http://edc.usgs. gov/products/map/drg.php

U.S. Geological Survey, 2005, National Atlas raw data download, geology chapter, accessed September 9, 2008, at http://www-atlas.usgs.gov/atlasftp.html?openChapters $=$ chp geol\#chpgeol

U.S. Geological Survey, 2008a, Geographic Names Information System, accessed June 18, 2008, at http://geonames. usgs.gov/pls/gnispublic 
U.S. Geological Survey, 2008b, Long term-method detection levels, Branch of Quality Systems, accessed September 4, 2008, at http://bqs.usgs.gov/ltmdl/

U.S. Geological Survey, 2008c, Water use in the United States, accessed March 18, 2009, at http://water.usgs.gov/watuse/

U.S. Geological Survey, 2009, National Geologic Map Database, Geologic Names Lexicon "GEOLEX," accessed June 15, 2009, at http://ngmdb.usgs.gov/Geolex/

U.S. Soil Conservation Service, 1967, Soil survey of Columbiana County, Ohio: Washington, D.C., U.S. Soil Conservation Service, $132 \mathrm{p}$.

U.S. Soil Conservation Service, 1971, Soil survey of Stark County, Ohio: Washington, D.C., U.S. Soil Conservation Service, $157 \mathrm{p}$.

U.S. Soil Conservation Service, 1974, Flood hazard analyses: Fox Run, Stark and Wayne Counties, Ohio: Washington, D.C., U.S. Soil Conservation Service, 7 p.

This report is an analysis of the flood hazard for Fox Run. The river flows eastward through Little Fox Lake in Wayne County on into Stark County where it joins the Tuscarawas River and drains a total of $14.2 \mathrm{mi}^{2}$. The primary land use in the basin of gently sloping land is agricultural. Projections to 1990 estimate 65 percent of the area will be single family homes of 0.5 to 1 acre with most in Lawrence Township (Stark County).

U.S. Soil Conservation Service, 1975a, Flood hazard analyses report East Branch Nimishillen Creek, Stark County, Ohio: Washington, D.C., U.S. Soil Conservation Service, 16, 3 p.

U.S. Soil Conservation Service, 1975b, Muskingum River Basin: Type IV survey report, Ohio: Columbus, Ohio, $236 \mathrm{p}$.

U.S. Soil Conservation Service, 1977, Soil survey of Medina County, Ohio: Washington, D.C., U.S. Soil Conservation Service, $119 \mathrm{p}$.

U.S. Soil Conservation Service, 1978, Soil survey of Portage County, Ohio: Washington, D.C., U.S. Soil Conservation Service, $113 \mathrm{p}$.

U.S. Soil Conservation Service, 1981, Soil survey of Belmont County, Ohio: Washington, D.C., U.S. Soil Conservation Service, $178 \mathrm{p}$.

U.S. Soil Conservation Service, 1983, Soil survey of Carroll County, Ohio: Washington, D.C., U.S. Soil Conservation Service, $156 \mathrm{p}$.

U.S. Soil Conservation Service, 1984, Soil survey of Wayne County, Ohio: Washington, D.C., U.S. Soil Conservation Service, $201 \mathrm{p}$.
U.S. Soil Conservation Service, 1986, Soil survey of Tuscarawas County, Ohio: Washington, D.C., U.S. Soil Conservation Service, $186 \mathrm{p}$.

U.S. Soil Conservation Service, 1990, Soil survey of Summit County, Ohio: Washington, D.C., U.S. Soil Conservation Service, $117 \mathrm{p}$.

Ulteig, J.R., 1964, Upper Niagaran and Cayugan stratigraphy of northeastern Ohio and adjacent areas: Ohio Department of Natural Resources Report of Investigation 51, 48 p., 13 figs., 1 table, 8 pls.

Van Horn, R.G., 1976, Land areas in Summit County, Ohio: Geologic suitability for solid-waste disposal: Ohio Department of Natural Resources, Division of Geological Survey, Report of Investigations 98, scale 1:63,360.

This report describes areas suitable for placement of solidwaste landfills and appears to be a precursor to DRASTIC maps. The most suitable areas based on hydrogeology are those characterized by 50 feet of more of relatively impermeable unconsolidated materials generally characterized by fine-grained till. The report notes that the Sharon Conglomerate is the most important bedrock aquifer in Summit County.

Van Horn, R.G., 1979, Surficial materials of Summit County, Ohio: Ohio Department of Natural Resources, Division of Geological Survey, Report of Investigations 109, scale $1: 63,360$.

This is a map showing the distribution of surficial materials in Summit County. In the northern part of Summit County, the surficial deposit is the Hiram Till (silty clay). In the central part, the Hayesville and Lavery Tills (clayey silt) are present and in the southern part of the county, the Mogadore Till (pebbly clayey sand) is present. In the extreme southeastern and southern parts of the county, the Kent and Navarre Tills (silty clays and sand) are present.

Van Tuyl, D.W., 1947, Methods used in the investigation of the glacial aquifer in the valley of Middle Branch of Nimishillen Creek near Canton, Ohio: Geological Society of America Bulletin (December 1947), 58 (12, Part 2), p. 1279-1280.

In 1947, Canton pumped an average of $8 \mathrm{Mgal} / \mathrm{d}$ from wells screened in the glacial gravels in the valley of Middle Branch of Nimishillen Creek. Streamflow records for Middle Branch show that the flow per unit of drainage area is consistently less than for other nearby streams which drain areas of similar geology and topography. The measurements of flow at intervals along the stream show that losses occur in varying amounts depending on the stage of the stream and on groundwater levels. Infiltration rates have varied from zero to more than $3 \mathrm{Mgal} / \mathrm{d}$ per acre of stream bottom. At some periods as much as 33 percent of the flow of the stream infiltrates into the aquifer. Profiles of the water table 
to the north of the well field show that groundwater levels at times are above the stream level. When this condition exists during periods of high streamflow, potential recharge from the stream to the aquifer is rejected.

Vertrees, R.L., 1985: A guide for subsequent users of original data bases of the Ohio Capability Analysis Program (OCAP): The Ohio State University School of Natural Resources Report 85/1, $91 \mathrm{p}$.

This guide summarizes the use of the raster-format OCAP data sets that include soils, land use, groundwater, and geologic data.

Vormelker, J.D., 1981a, Bedrock topography of Summit County, Ohio: Ohio Department of Natural Resources, Division of Geological Survey, Open File Map 116, scale 1:63,360.

Vormelker, J.D., 1981b, Top-of-rock map of Summit County, Ohio: Ohio Department of Natural Resources, Division of Geological Survey, Open File Map 116, scale 1:62,500.

This map shows hand-drawn elevation contours on the bedrock surface. The information portrayed has been superseded by the 1:24,000-scale bedrock-topography maps.

Walk, M.F., and Godfrey, P.J., 1990, Effects of acid deposition on surface waters: Journal of New England Water Works Association, v.104, no. 4, p. 248-251.

Walker, A.C., 1959, Tuscarawas River Basin (upper portion) underground water resources: Ohio Department of Natural Resources, Division of Water, Ohio Water Plan Inventory File Index P-6, scale 1:125,000.

This map includes water-quality data from two wells completed in sandstone and two wells in sand and gravel (glacial) as follows: dissolved iron ranged from 0.5 to $1.7 \mathrm{mg} / \mathrm{L}$ (requiring treatment to reduce iron concentrations); chloride ranged from 1.6 to $6.0 \mathrm{mg} / \mathrm{L}$; total dissolved solids ranged from 26 to $310 \mathrm{mg} / \mathrm{L}$; hardness ranged from 185 to $570 \mathrm{mg} / \mathrm{L}$ as $\mathrm{CaCO}_{3}$, and $\mathrm{pH}$ ranged from 6.8 to 7.7 . A color-shaded map is mostly green, indicating well yields ranging from 5 to $25 \mathrm{gal} / \mathrm{min}$, and blue in areas along Chippewa Creek (Rittman), River Styx, and west towards Creston where well yields may range from 500 to $1,000 \mathrm{gal} / \mathrm{min}$. On the map, the area north of the Portage Lakes along Wolf Creek, which is colored green, has wells completed in sand and gravel lenses within thick glacial sediments, providing 5 to $25 \mathrm{gal} / \mathrm{min}$ to wells.

Walker, A.C., 1962a, A part of the lower portion Tuscarawas River Basin underground water resources: Ohio Department of Natural Resources, Division of Water, Ohio Water Plan Inventory P-10, scale 1:125,000.

Walker, A.C., 1962b, A portion of the middle of Muskingum River basin underground water resources: Ohio Department of Natural Resources, Division of Water, Ohio Water Plan Inventory P-16, scale 1:125,000.

Walker, A.C., 1969, Stillwater Creek Basin underground water resources: Ohio Department of Natural Resources, Division of Water, Ohio Water Plan Inventory File Index P-7, scale 1:125,000.

Walker, A.C., 1991, Ground-water resources of Guernsey County: Ohio Department of Natural Resources, Division of Water, scale 1:63,000.

Walker, A.C., and Crumley, T.A., 1979, Ground-water resources of Portage County: Ohio Department of Natural Resources, Division of Water, scale 1:63,000.

This is a color coded map of well yields in Portage County. Northern Portage County, which is colored yellow, is underlain by Pottsville-age Massillon Sandstone and Sharon Conglomerate, yielding 25 to $100 \mathrm{gal} / \mathrm{min}$. The southeastern corner of the county, which is colored green, had well yields generally less than $25 \mathrm{gal} / \mathrm{min}$ from the Pottsville Sandstone. The southwestern part of the county within the Tuscarawas River Basin, colored blue, has interbedded sands and gravels, yielding from 100 to $300 \mathrm{gal} / \mathrm{min}$.

Walker, A.C., and Jiang, X., 1991, Ground water resources of Carroll County: Ohio Department of Natural Resources, Division of Water, scale 1:62,500.

This is a color-coded map of well yields Carroll County. Most of the western and southern parts of Carroll County, colored orange or brown, yield less than $3 \mathrm{gal} / \mathrm{min}$ to as much as $10 \mathrm{gal} / \mathrm{min}$. The northwestern part of the county, colored green, had well yields ranging from 10 to $25 \mathrm{gal} / \mathrm{min}$ from sandstones or sandy shales. Small areas in the northwestern part of the county near Malverne and Minerva along Sandy Creek have permeable sand and gravels; well yields were greater than $100 \mathrm{gal} / \mathrm{min}$.

Walker, A.C., 1962a, Lower portion of the Muskingum River basin and adjacent Ohio River tributaries: Ohio Department of Natural Resources, Division of Water, Ohio Water Plan Inventory File Index P-10, scale 1:125,000.

Walker, A.C., 1962b, A Portion of the Middle Muskingum River Basin Underground Water Resources: Ohio Department of Natural Resources, Division of Water, Ohio Water Plan Inventory File Index P-16, scale 1:125,000.

Walker, A.C., and Schottenstein, C.A., 1979, Ground-water resources of Stark County: Ohio Department of Natural Resources, Division of Water, scale 1:63,000.

This is a color-coded map of well yields in Stark County. The eastern and southeastern parts of the county, colored green, have sandstones and sandy shales, yielding about $25 \mathrm{gal} / \mathrm{min}$. The northwestern part of the county, colored yellow, is underlain by Pottsville sandstones that may provide 25 to $100 \mathrm{gal} / \mathrm{min}$ to wells. The Canton and Massillon areas, 
colored purple and blue, provided from 100 to $500 \mathrm{gal} / \mathrm{min}$ from sand and gravel deposits (purple-shaded areas underlain by sand and gravel provide the "best ground-water areas in Stark County"). This map also shows a hachured area of sand and gravel deposits susceptible to infiltration of chloride from the Tuscarawas River. The report indicates that, within this area, spacing of wells and rates of pumping should be carefully controlled to avoid induction of chloride in the aquifer.

Walker, A.C., and Stewart, R.L., 1991, Ground-water resources of Belmont County: Ohio Department of Natural Resources, Division of Water, scale 1:62,500.

Wayne County Planning Department, 2006, Tomorrow together: Wayne County comprehensive plan (draft): The Board of the Wayne County Commissioners, variously paginated, accessed September 27, 2006, at http://www. wayneohio.org/planning/plan.html

This planning document lists natural constraints for development in Wayne County, including severe septic limitations (which affect about 78 percent of total land area), groundwater availability (which affects about 37 percent), severe slope (which affects about 8 percent), and areas prone to flooding (which affects about 9 percent). In general, Wayne County offers adequate groundwater quality and yields throughout the county, although portions have experienced low flows (such as the West Salem area). An outstanding aquifer is found along Killbuck Creek. As stated in the report, a primary objective within the county should be to protect groundwater resources by discouraging inappropriate development over or adjacent to groundwater recharge areas and aquifers, adopting wellhead protection regulations to protect aquifers, and conducting a countywide groundwater supply survey to delineate resources and identify aquifer contamination potentials.

Weatherington-Rice, J.B.P., 2004, Fracture occurrence and ground water pollution in Ohio's glacial and lacustrine deposits: Columbus, Ohio, Ohio State University, Ph. D. dissertation, $400 \mathrm{p}$.

This dissertation consists of five journal articles and includes information on fracture occurrence within glacial deposits in the Tuscarawas River Basin. One of the articles provides an independent evaluation of 21 sites in Ohio where fractures have been identified in glacial tills from boring samples, backhoe pits, and stream cuts.

Weitzel, R.L., and Bates, J.M., 1981, Assessment of effluent impacts through evaluation of periphyton diatom community structure, in Bates, J.M., Weber, C.I., eds., Ecological assessments of effluent impacts on communities of indigenous aquatic organisms: Philadelphia, Pa., American Society for Testing and Materials, p. 142-165.

The effects of discharges of copper-containing electroplating wastewater on the biota of the Muskingum River were evaluated by studies of the diatom community following the occurrence of high mortality among freshwater mussels downstream from the discharge point. The results indicated decreased species richness and diversity in the diatom communities collected from artificial substrates.

Wellman, J.M., 1998, A stream sediment geochemical survey as an indicator of potential contamination by heavy metals of the Muskingum River, southeast Ohio: Dayton, Ohio, Wright State University, M.S. thesis, 88 p.

Westfall, A.O., and Webber, E.E., 1977, Time of travel of solutes in the Tuscarawas River Basin, Ohio, August and September, 1974: U.S. Geological Survey Water-Resources Investigations Report 77-0023, 7 p.

A series of time-of-travel dye studies were done in August and September 1974 on a 106-mile reach of the Tuscarawas River. The river was divided into five sub-reaches, and separate dye tests were done within each of the sub-reaches. The study started 3 miles downstream from Barberton to a point 0.3 miles upstream from the confluence with the Walhonding in Coshocton. At about 50-percent duration, the time-of-travel of the peak concentration was 137 hours for the entire 106-mile reach. The leading edge of the dye reached the lower-most station after about 119 hours.

Weston, R.F., 1968, Surface water quality report for Muskingum River Basin, State of Ohio: West Chester, Pa., R.F. Weston, variously paginated.

This report summarizes land use, water use, and surfacewater quality. Land use was 67 percent agricultural in 1959 for the entire Muskingum River Basin. The 1960 population for the basin was $1,157,215$ and increased to $1,215,808$ in 1965 . From 1940 to 1950 , population increased by 11.3 percent; from 1950 to $1960,17.9$ percent; and from 1960 to $1965,5.1$ percent. Population was projected to be $1,806,000$ by 1990 . Average per capita water use was $115 \mathrm{gal} / \mathrm{d}$ and ground water provided more than 80 percent of public water supply in basin.

The Upper Tuscarawas River Basin had elevated concentrations of nitrate and phosphorus. Wolf Creek at Barberton had elevated organic and inorganic industrial discharge. The concentration of dissolved iron was typically greater than $1 \mathrm{mg} / \mathrm{L}$; thermal contamination was considerable; and chloride levels were commonly between 1,000 and $2,000 \mathrm{mg} / \mathrm{L}$. There also were substantial bacterial issues and sewage problems.

White, G.W., 1947, Waynesburg coal in Harrison and northern Belmont Counties, Ohio, and revision of Dunkard (Permian) boundary: Ohio Journal of Science, v. 47, no. 2, p. 55-58.

White, G.W., 1949, Geology of Holmes County: Ohio Department of Natural Resources Bulletin 47, 373 p. 
White, G.W., 1951, Illinoian and Wisconsinan drift of the southern part of the Grand River lobe in eastern Ohio: Geological Society of America Bulletin, v. 62, p. 967-978.

This report includes a plate showing details of the Illinoian and Wisconsinan glacial boundaries and associated deposits. Glacial drifts of Wisconsin and Illinoian age occur in the southern part of the Grand River lobe in eastern Ohio. The Illinoian, which occupies a belt only 2 to 5 miles wide, extends eastward from Canton across Stark and Columbiana Counties. This is mainly till, now discontinuous and thin. Oxidation reaches a depth of 12 feet or more, and leaching reaches 11 feet or more. Small areas of the Illinoian kames and kame terraces remain. In the Wisconsinan till, which covers the area north of the Illinoian, oxidation reaches depths of 8 to 11 feet and leaching, 5 to 7 feet. A partially discontinuous end moraine lies 1 to 2 miles inside the southern limit of this drift, and a very strong moraine lies along the west side of the lobe. Within the Wisconsinan area, relatively minor kame terraces occupy some of the valleys. The Wisconsinan ice disappeared mainly by northward retreat of an ice edge, but stagnated to a limited extent in small areas.

White, G.W., 1967, Glacial geology of Wayne County, Ohio: Ohio Department of Natural Resources, Division of Geological Survey, Report of Investigations 62, 39 p.

A map included with this report shows that Wayne County is entirely covered by glacial drift consisting largely of Hayesville Till ground and end moraines. Wisconsinan kames and outwash deposits also are present. Kettle holes, now incorporated in flood plains, contain muck and peat. The eastern part of the county valley fill along Chippewa Creek, Little Chippewa Creek, and Sugar Creek is characterized by flood plain and kettle holes. Silt and other alluvium are present on valley floors, are often thin, and overlie material of different character. Yellow-colored areas on the map near Creston and Sterling indicate valley-train deposits that are low outwash terraces with well-washed gravel and sand. The bottom of the Killbuck Creek valley from a point northwest of Wooster southward into Holmes County and far south across that county is a long, narrow lacustrine plain. The down valley slope is less than $1 \mathrm{ft}$ to a little more than $1 \mathrm{ft}$ per mi. Before the ditching and straightening of the channel of Killbuck Creek, floods spread over the valley and persisted for weeks or even months, turning the valley into a lake.

White, G.W., 1973, Glacial geology of Holmes County, Ohio: Ohio Department of Natural Resources, Division of Geological Survey, Report of Investigations 91, scale 1:90,000.

This is a map of the glacial deposits in Holmes County. Only the northern half of county is glaciated and is covered primarily with till. Silt and other alluvium fill valleys are present in the central portion of the county, especially near Killbuck. Numerous kames and kame terraces along valley walls are present along Martin's Creek and near Martinsville.
White, G.W., 1979, Extent of till sheets and ice margins in northeastern Ohio: Ohio Department of Natural Resources Geological Note 6, one sheet.

White, G.W., 1982, Glacial geology of northeastern Ohio: Ohio Department of Natural Resources Bulletin 68, 75 p.

White, G.W., 1984, Glacial geology of Summit County, Ohio: Ohio Department of Natural Resources, Division of Geological Survey, Report of Investigations 123, 25 p.

This is a revision and expansion of Smith and White (1953) and provides an excellent map of glacial sediments in the county. The Kent Till (Late Wisconsinan/Woodfordian age at about 24,000 years before present is within the Cuyahoga lobe in northern Summit County and the margin of the Grand River Lobe in extreme eastern Summit County. The Lavery Till (19,000 years before present) covers northern Summit County as far south as Akron but is at the surface only in small areas. The Hiram Till (17,000 years before present) also covers northern Summit County and conceals the Lavery Till. The Portage Lakes were formed along an intricate network of esker-like crevasse fillings, sharp kames, and very large kettle holes. The depressions that form the basins of the lakes are the models of the last ice blocks and represent the remnants of the Mogadore ice sheet. Groundwater is abundantly produced from sands and gravels of the Mogadore Till. Waste disposal of both solids and liquids within sites located on the till ranges from what the authors label favorable to very unfavorable.

White, G.W., and Guckenheimer, L.M., 1979, Extent of till sheets and ice margins in northeastern Ohio: Ohio Department of Natural Resources, Division of Geological Survey, 6 sheets, scale 1:900,000.

White, G.W., and Lamborn, R.E., 1949, Geology of Holmes County, Ohio: Ohio Department of Natural Resources, Division of Geological Survey, Bulletin 47, 373 p.

White, G.W., and Totten, S.M., 1979, Glacial geology of Ashtabula County, Ohio: Ohio Department of Natural Resources Report of Investigation 112, 52 p.

White, G.W., and Totten, S.M., 1982, Glacial geology of northeastern Ohio: Ohio Department of Natural Resources, Division of Geological Survey, Bulletin 68, 75 p.

White, G.W., and Totten, S.M., 1985, Glacial geology of Columbiana County, Ohio: Ohio Department of Natural Resources, Division of Geological Survey, Report of Investigations 129, 25 p.

Wilde, F.D., Radtke, D.B., Gibs, Jacob, and Iwatsubo, R.T., eds., 2004, Processing of water samples (version 2.1): U.S. Geological Survey Techniques of Water-Resources Investigations, book 9, chap. A5, accessed November 27, 2007, at http://pubs.water.usgs.gov/twri9A5/ 
This is a guidebook for water-quality sampling conducted by the U.S. Geological Survey. It also contains special sections on sampling procedures and potential contamination issues related to wastewater compounds.

Williams, E.B., 1973, An investigation of chloride contamination in Tuscarawas and Muskingum River Valleys, Ohio: Columbus, Ohio, Ohio State University, M.S. thesis, p.107

This thesis is a revisit to the chloride contamination problem in the Tuscarawas River. At the time of this study, samples from Chippewa Creek contained $281 \mathrm{mg} / \mathrm{L}$ of chloride, whereas samples from the Tuscarawas River below Barberton contained 4,370 mg/L. Above Barberton, the Tuscarawas River contained only $62 \mathrm{mg} / \mathrm{L}$ of chloride. The Tuscarawas River at Massillon had 3,200 and 2,040 mg/L of chloride in November 1971 and January 1972, respectively, and the Tuscarawas River at Newcomerstown had 437 and $416 \mathrm{mg} / \mathrm{L}$ on these same dates.

Williams, N.E., 1958, Preliminary engineering report: Hugle Run Lake, Stark County, Ohio: Ohio Department of Natural Resources, Division of Water, $21 \mathrm{p}$.

This report describes a proposed lake site just north of Minerva. It was never built and it does not appear on a 1988 hydrologic unit code (HUC) map.

Williams, S.E., 1989, The ground water pollution potential of Stark County, Ohio: Athens Ohio, Ohio University, M.S. thesis, p.69.,

Williams, S.E., 1991, Ground water pollution potential of Stark County, Ohio: Ohio Department of Natural Resources, Division of Water, Ground Water Pollution Potential Report $6,75 \mathrm{p}$.

This is a DRASTIC map for Stark County. The two most productive bedrock aquifers are the Sharon Conglomerate and Massillon Sandstone of the lower Pottsville Group; they can produce sustained yields of $50 \mathrm{gal} / \mathrm{min}$. Most of the county is shaded blue and green, indicating DRASTIC ratings of 139 or less. The valley fill around Sandy Creek, Nimishillen Creek (Canton), and the Tuscarawas River (Massillon) are color-shaded orange or yellow with ratings ranging from 160 to 199 .

Wilson, W.E., 1991, Hydrogeologic analysis of the upper Tuscarawas River basin, Summit and Stark Counties, Ohio: Akron, Ohio, University of Akron, M.S. thesis, 105 p.

Winslow, J.D., and White, G.W., 1966, Geology and groundwater resources of Portage County, Ohio: U.S. Geological Survey Professional Paper 511, 80 p.

This report describes the sediments, rocks, and groundwater resources of Portage County. At the time of the 1960 census, population was 91,798 . Plate 5 shows a general guide to groundwater in the county with the areas of greatest availability/best water quality in the western part of the county, in the north-south trending buried valley. The water is generally hard to very hard and contains moderate to excessive amounts of dissolved solids. Water derived from the Berea Sandstone is relatively soft, but this water is not necessarily low in mineral content. Manganese was present at concentrations up to $0.66 \mathrm{ppm}$.

Woods, A.J., Omernik, J.M., Brockman, C.S., Gerber, T.D., Hosteter, W.D., and S.H. Azevedo, 1998, Ecoregions of Indiana and Ohio (two- sided color poster with map, descriptive text, summarytables, and photographs): U.S. Geological Survey, Reston, Va., scale 1:500,000, accessed September 21, 2006, at http://education.usgs.gov/common/ resources/mapcatalog/images/environmental/ecoregion_ ohio1_front.pdf

Wright, A.J., 1953, Economic geography of Ohio: Ohio Department of Natural Resources Bulletin 50, 217 p.

Wright, J.C., 1950, The limnology of Atwood Lake, a flood control reservoir: Columbus, Ohio, Ohio State University, Ph. D. dissertation, 157 p.

Youngquist, C.V., Langbein, W.B., Smith, W.E., and Showalter, A.K., 1941, Flood of August 1935 in the Muskingum River basin, Ohio: U.S. Geological Survey Water-Supply Paper 869, 118 p.

This report describes a flood within the Muskingum River Basin in 1935. More than 8 inches of precipitation fell over an area of $400 \mathrm{mi}^{2}$ during a 12-hour period on August 6-7, 1935. Property loss was estimated at \$6 million.

Zbasnik, B.S., 1996, Application of Lloyd Bitzer's rhetorical situation to the Ashland Inc. oil spill on the Tuscarawas River: Akron, Ohio, University of Akron, M.A. thesis, 60 p.

Zielinski, R.A., and Finkelman, R.B., 1997, Radioactive elements in coal and fly ash: abundance, forms, and environmental significance: U.S. Geological Survey Fact Sheet FS-163-97, accessed November 28, 2007, at http://greenwood.cr.usgs.gov/energy/factshts/163-97/ FS-163-97.html

Zogorski, J.S., Carter, J.M., Ivahnenko, Tamara, Lapham, W.W., Moran, M.J., Rowe, B.L., Squillace, P.J., and Toccalino, P.L., 2006, The quality of our Nation's watersVolatile organic compounds in the Nation's ground water and drinking-water supply wells: U.S. Geological Survey Circular 1292, 101 p.

Zoller, C.T., Raab, J.M., Brown, L.C., and Ricker, K.T., undated a, Tuscarawas County ground-water resources: Ohio State University Extension Fact Sheet AEX-490.79, accessed September 20, 2006, at http://ohioline.osu.edu/ aex-fact/0490_79.html 
This is an overview of Tuscarawas County's groundwater resources, including definitions of aquifer and well yield. Ohio Department of Natural Resources observation wells and chemical analysis sites are shown on a generalized map of well yields. All wells sampled as part of this study contained excess hardness and iron.

Zoller, C.T., Ricker, K.T., and Brown, L.C., undated b, Water resources of Tuscarawas County: Ohio State University Extension Fact Sheet AEX-480.79, accessed September 20, 2006, at http://ohioline.osu.edu/aex-fact/0480_79.html

This is an overview of water resources for Tuscarawas County, including precipitation, groundwater, surface water, water use, and water quality. Average rainfall for the Tuscarawas County area was 40 inches per year, providing 10.4 inches of runoff to streams and lakes. About 6.4 inches had the potential to recharge aquifers. Land use was 46-percent farmland. Nitrate was noted as a water-quality issue. 



\section{Appendices}

Appendix 1. Summary of Literature Review for the Tuscarawas River Basin

Appendix 2. Results of Analyses of Water Samples Collected within the Tuscarawas

River Basin, 2006

Appendix 3. Glossary of Water-Quality Reporting Levels and Qualifiers 


\section{Appendix 1. Summary of Literature Review for the Tuscarawas River Basin}

[undated, no date on publication; consolidated refers to bedrock aquifers; unconsolidated refers to sand and gravel aquifers]

Basin characteristics

\begin{tabular}{ll}
\hline Ecoregions & Omernick (1987), Woods and others (1998) \\
Geography & Peattie (1923), Wright (1950) \\
Geomorphology & Preston (1987) \\
Physiography & Fenneman (1938) \\
Soils & Morse (1939), Boyce and others (1960), U.S. Soil Conservation Service (1967, 1971, 1977, 1978, 1981, 1983, 1984, \\
& 1986, 1990), Bartlett and others (1984), Natural Resources Conservation Service (1998a, 1998b, 2002, 2005), \\
& Ohio Department of Natural Resources, 2008b
\end{tabular}

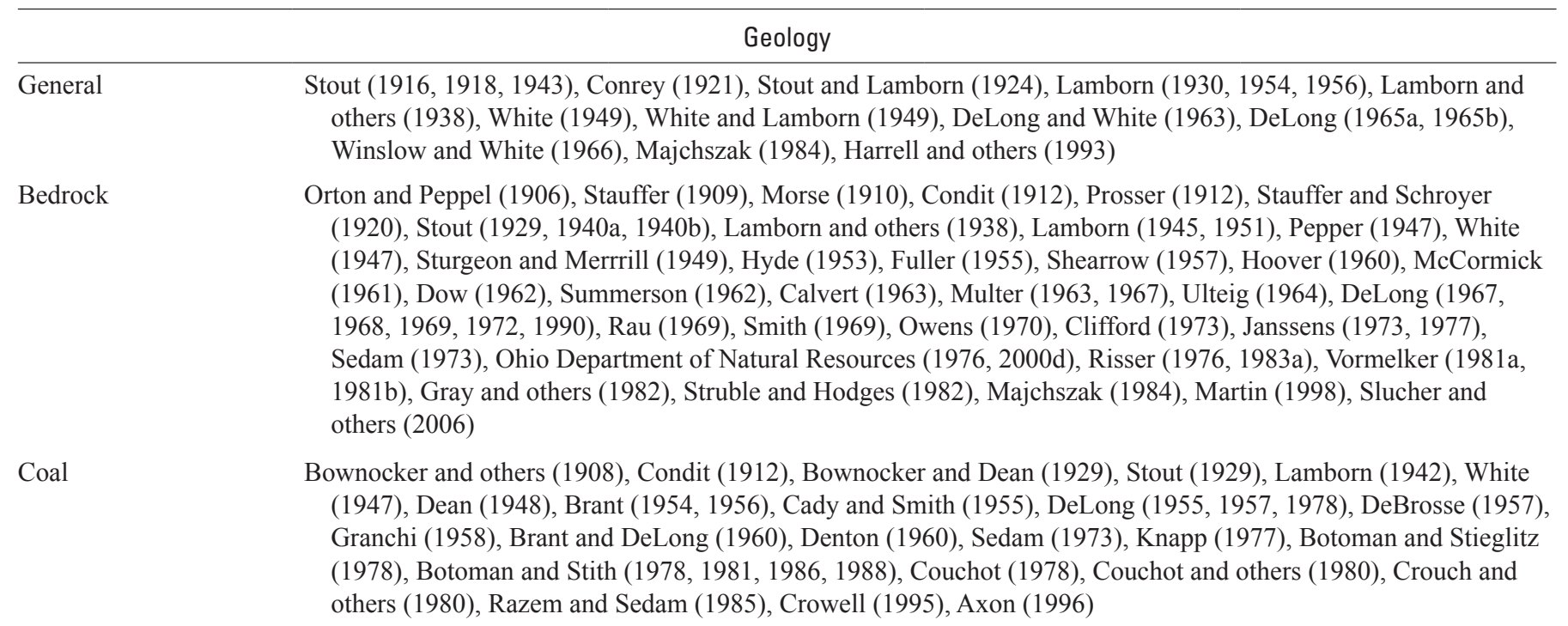

Geophysics Heiskanen and Uotila (1956), Morrison (1996)

Glacial and unconsolidated

Coffey (1930), Schaefer and others (1946), Van Tuyl (1947), Smith (1949), White (1951, 1967, 1973, 1979, 1982, 1984), Cummins (1959), Forsyth (1961), Goldthwait and others (1967), Ohio Department of Natural Resources (1978a, 1983, 1993a, 1993b, 2000a, 2000b, 2000c), Van Horn (1979), White and Guckenheimer (1979), White and Totten (1979, 1982, 1985), Hull (1980, 1987), Risser (1981, 1983b, 1986, 1987), Himes (1982), Totten (1988), Rizzo (1993), Leberfinger (1995), Richards and Wallrabenstein (1995), Pavey and others (1999), Weatherington-Rice (2004), Masters and Razem (undated)

Minerals

Orton and Peppel (1906), Dachnowski (1912), Bownocker and Stout (1928), Stout (1940a, 1940b, 1944, 1946), Stout and Schoenlaub (1945), Pepper (1947), Smith (1949), Ohio Department of Natural Resources (1963), Clifford (1973), Hull (1980, 1987), Risser (1981, 1986), Carlson (1991), Kelly and Matos (2009)

Oil and gas

Bownocker (1903), Lamborn (1952), Multer (1963), Ohio River Valley Water Sanitation Commission (1951), Janssens and de Witt (1976), Struble and Hodges (1982), Riley and others (2004)

Hydrology

General

Harker (1943a), Harker and Bernhagen (1943a), Stout and others (1943), Cummins and Sanderson (1947), Cummins (1959), Schmidt (1962a, 1962b, 1978, 1994), Sedam (1973), Groenewold (1974), Crowell and Crumley (1978), Crowell and Schottenstein (1979a, 1979b, 1980), Heaton (1982), Kerschner (1980), Engelke and Roth (1981), Preston (1987), Eshler (1988), Garvey (1988), Wilson (1991), Rizzo (1993), Chowdhury (1995), Chowdhury and others (2003), Akin (2006), Beck and others (undated a), Golden and others (undated a, undated b], Hogan and others (undated a), Little and others (undated), Oelker and others (undated a), Oelker and others (undated b), Schumacher and others (undated a) 
Hydrology-Continued

\begin{tabular}{|c|c|}
\hline Computer simulations & Rashid and others (1992), Breen and others (1995), Haefner (2002) \\
\hline $\begin{array}{l}\text { Contaminated sites/ } \\
\text { wastewater treat- } \\
\text { ment/waste disposal/ } \\
\text { landfills }\end{array}$ & $\begin{array}{l}\text { Ohio River Valley Water Sanitation Commission (1951), Jones (1961), Rau (1972, 1974), Williams (1973), } \\
\text { Groenewold (1974), Clifford (1975), Van Horn (1976), Babington and Fisher (1977), Bachman and Morgan } \\
\text { (1983), Hull (1984), Majchszak (1984), Opatrny and Larlham (1985), Bair and Norris (1989), Jackson and } \\
\text { others (1989), Dumouchelle and Bair (1994), Zbasnik (1996), Barber and others (1997), Francisco and Shakoor } \\
\text { (1997), Ohio Environmental Protection Agency (2003, 2005), Weatherington-Rice (2004), Stark County Health } \\
\text { Department (2005) }\end{array}$ \\
\hline $\begin{array}{l}\text { Groundwater, } \\
\text { general }\end{array}$ & $\begin{array}{l}\text { Harker (1943b, 1943c), Harker and Ohio Water Supply Board (1943, 1944a, 1944b), Harker and others (1943), } \\
\text { Schaefer and others (1946), Cummins and Sanderson (1947), Van Tuyl (1947), Smith and White (1953), Schmidt } \\
\text { and Walker (1954), Jones and others (1958), Cummins (1959), Walker (1959, 1962a, 1962b, 1962c, 1991), Ohio } \\
\text { Water Commission (1960), Prée (1962b), Schmidt (1962a, 1962b, 1978, 1994), Winslow and White (1966), } \\
\text { Sedam and Stein (1970), Ohio Drilling Company (1971), Sedam (1973, 1991), Crowell and Crumley (1978), } \\
\text { Crowell and Schottenstein (1979a, 1979b, 1980), Walker and Crumley (1979), Walker and Schottenstein (1979), } \\
\text { Khourey (1981), Mayhew (1985), Razem and Sedam (1985), Booth (1988), Sugar (1988), Bair and Norris (1989), } \\
\text { Barber (1989), Iqbal (1990), Walker and Jiang (1991), Walker and Stewart (1991), Dai and others (1992), Dai } \\
\text { (1993), Rizzo (1993), Sedam and Francy (1993), Dumouchelle and Bair (1994), Jost (1994), Breen and others } \\
\text { (1995), Chowdhury (1995), Richards and Wallrabenstein (1995), Angle and others (2000), Ohio Department of } \\
\text { Natural Resources (2000c, 2000d), Eckstein and others (2001), Haefner (2002), Chowdhury and others (2003), } \\
\text { Weatherington-Rice (2004), U.S. Environmental Protection Agency (2005), Beck and others (undated b), Golden } \\
\text { and others [undated a], Hogan and others (undated b), Oelker and others (undated c, undated d), Schumacher and } \\
\text { others (undated b), Zoller and others (undated a) }\end{array}$ \\
\hline
\end{tabular}

\begin{tabular}{|c|c|c|c|c|}
\hline $\begin{array}{l}\text { Groundwater, by county } \\
\text { and specific topic }\end{array}$ & Water resources & $\begin{array}{l}\text { Hydrogeology and (or) } \\
\text { groundwater resources }\end{array}$ & Pollution-potential maps & $\begin{array}{c}\text { Water-level } \\
\text { and (or) potentiometric } \\
\text { surface maps }\end{array}$ \\
\hline Belmont & $\begin{array}{l}\text { Schumacher and others } \\
\text { (undated a) }\end{array}$ & $\begin{array}{l}\text { Walker (1969), } \\
\text { Walker and Stewart (1991), } \\
\text { Schumacher and others } \\
\quad \text { (undated b) }\end{array}$ & Angle and Jonak (2002) & \\
\hline
\end{tabular}

\begin{tabular}{|c|c|c|c|c|}
\hline Carroll & $\begin{array}{l}\text { Pree }(1962 a), \\
\text { Hogan and others } \\
\quad \text { (undated a) }\end{array}$ & $\begin{array}{l}\text { Pree (1962b), } \\
\text { Schmidt (1962a, } 1962 \text { b), } \\
\text { Sedam and Stein (1970), } \\
\text { Walker and Jiang (1991), } \\
\text { Hogan and others } \\
\quad \text { (undated b) }\end{array}$ & Angle and others (2003b) & $\begin{array}{l}\text { Consolidated } \\
\text { Angle (2006a) } \\
\text { Unconsolidated } \\
\text { Angle (2006b) }\end{array}$ \\
\hline Columbiana & $\begin{array}{l}\text { Stamm and others } \\
\text { (undated) }\end{array}$ & $\begin{array}{l}\text { Pree }(1962 b), \\
\text { Crowell and Crumley } \\
\quad(1978), \\
\text { Risser (1986) }\end{array}$ & Angle (1994a) & $\begin{array}{l}\text { Consolidated } \\
\text { Sprowls (2007a) }\end{array}$ \\
\hline Coshocton & $\begin{array}{l}\text { Golden and others } \\
\quad \text { (undated b) }\end{array}$ & $\begin{array}{l}\text { Walker (1962a), } \\
\text { Himes (1982), } \\
\text { Sugar (1988), } \\
\text { Golden and others } \\
\quad \text { (undated b) }\end{array}$ & Spahr (1995) & \\
\hline Guernsey & $\begin{array}{l}\text { Little and others } \\
\text { (undated) }\end{array}$ & $\begin{array}{l}\text { Walker (1969), } \\
\text { Sedam and Stein (1970), } \\
\text { Walker (1991) }\end{array}$ & & \\
\hline
\end{tabular}




\begin{tabular}{|c|c|c|c|c|}
\hline \multicolumn{5}{|c|}{ Hydrology-Continued } \\
\hline Harrison & $\begin{array}{l}\text { Hogan and others } \\
\quad \text { (undated a) }\end{array}$ & $\begin{array}{l}\text { Schmidt (1962a), } \\
\text { Walker (1969), } \\
\text { Sedam and Stein (1970), } \\
\text { Crowell and Schottenstein } \\
\quad(1980), \\
\text { Hogan and others } \\
\quad \text { (undated b) }\end{array}$ & Angle and Walker (2002) & $\begin{array}{l}\text { Consolidated } \\
\text { Raab and Sprowls (2006) }\end{array}$ \\
\hline Holmes & $\begin{array}{l}\text { Schmidt (1962a), } \\
\text { Crowell and Schottenstein } \\
\quad(1979 a)\end{array}$ & Angle and Bonifas (2002) & & \\
\hline Stark & $\begin{array}{l}\text { Pree }(1962 a), \\
\text { Oelker and others } \\
\quad(\text { undated a) }\end{array}$ & $\begin{array}{l}\text { Schaefer and others (1946), } \\
\text { Van Tuyl (1947), } \\
\text { Walker (1959), } \\
\text { Pree (1962b), } \\
\text { Schmidt (1962a), } \\
\text { Sedam and Stein (1970), } \\
\text { Walker and Schottenstein } \\
\text { (1979), } \\
\text { Oelker and others } \\
\quad \text { (undated c), } \\
\text { Wilson (1991) }\end{array}$ & Williams $(1989,1991)$ & $\begin{array}{l}\text { Consolidated } \\
\text { Crist and Raab (2006) } \\
\text { Unconsolidated } \\
\text { Angle (2006c), } \\
\text { Bair and Norris (1989), } \\
\text { Dumouchelle and Bair } \\
\quad \text { (1994) }\end{array}$ \\
\hline Summit & $\begin{array}{l}\text { Stafford (1954), } \\
\text { Oelker and others } \\
\quad \text { (undated b) }\end{array}$ & $\begin{array}{l}\text { Smith and White (1953), } \\
\text { Walker (1959), } \\
\text { Rau (1969), } \\
\text { Heaton (1982), } \\
\text { Kerschner (1980), } \\
\text { Garvey (1988), } \\
\text { Wilson (1991), } \\
\text { Schmidt (1994), } \\
\text { Oelker and others } \\
\quad \text { (undated d) }\end{array}$ & Angle and others (2003a) & $\begin{array}{l}\text { Consolidated } \\
\text { Sprowls (2007b) } \\
\text { Unconsolidated } \\
\text { Sprowls and others (2007) }\end{array}$ \\
\hline Tuscarawas & $\begin{array}{l}\text { Cummins and Sanderson } \\
\text { (1947), } \\
\text { Zoller and others } \\
\quad \text { (undated b) }\end{array}$ & $\begin{array}{l}\text { Kaser (1960), } \\
\text { Schmidt (1962a, 1962b), } \\
\text { Walker (1962a, 1969), } \\
\text { Barber (1989), } \\
\text { Tuscarawas County } \\
\quad \text { Metropolitan Sewer } \\
\quad \text { District (2006), } \\
\text { Zoller and others } \\
\quad \text { (undated a) }\end{array}$ & Angle and Baker (2001) & $\begin{array}{l}\text { Consolidated } \\
\text { Sprowls (2007c) } \\
\text { Unconsolidated } \\
\text { Raab (2006) }\end{array}$ \\
\hline
\end{tabular}




\begin{tabular}{|c|c|c|c|c|}
\hline \multicolumn{5}{|c|}{ Hydrology-Continued } \\
\hline Wayne & $\begin{array}{l}\text { Preston (1987), } \\
\text { Rizzo (1993), } \\
\text { Beck and others } \\
\quad \text { (undated a) }\end{array}$ & $\begin{array}{l}\text { Walker (1959), } \\
\text { Schmidt (1962a, 1962b), } \\
\text { Crowell and Schottenstein } \\
\quad(1979 b), \\
\text { Springer (1987), } \\
\text { Iqbal (1990), } \\
\text { Chowdhury and others } \\
\quad \text { (2003), } \\
\text { Jost (1994), } \\
\text { Chowdhury (1995), } \\
\text { Breen and others (1995), } \\
\text { Beck and others (undated b) }\end{array}$ & $\begin{array}{l}\text { Jost (1994), } \\
\text { Chowdhury (1995), } \\
\text { Angle and Akins (2002), } \\
\text { Chowdhury and others } \\
\text { (2003) }\end{array}$ & $\begin{array}{l}\text { Consolidated } \\
\text { Sprowls (2006a) } \\
\text { Unconsolidated } \\
\text { Sprowls (2006b) }\end{array}$ \\
\hline
\end{tabular}

Recharge

Surface water (streams, reservoirs, lakes)

Water supply, water use

Watershed planning, Total Maximum Daily Loads, Acid Mine Drainage Abatement and Treatment Plans

Wetlands, bogs, swamps, fens
Bonta and Muller (1999), Dumouchelle and Schiefer (2002), Breen and others (1995), Kazman (1949)

Coffey (1930), U.S. Army Corps of Engineers (1935, 1943, 1967, 2006a, 2008), Cummins and Sanderson (1947), Kazman (1949), Wright (1950), Williams, N.E. (1958), Williams, E.B. (1973), Schmidt and Ohio Dept. of Natural Resources (1959, 1962a, 1962b), Potter (1961), Walker and Ohio Dept. of Natural Resources (1962), Weston (1968), U.S. Department of Transportation (1974), U.S. Environmental Protection Agency (1975a, 1975b, 1975c, 1978), Westfall and Webber (1977), Tobin and Youger (1978, 1979), Bowell (1980), Bartlett and others (1984), Angelo and Youger (1985), Opatrny and Larlham (1985), Koltun and Roberts (1990), Black (1991), Sedam (1991), Sedam and Francy (1993), Breen and others (1995), Davic and others (1997), Koltun and Sherwood (1998), U.S. Department of Agriculture, Natural Resources Conservation Service (2001), Dumouchelle and Schiefer (2002), Koltun (2003), Espinoza (2005)

Foulk (1925), Ohio Department of Public Works and Dayton Morgan Engineering Co. (1931), Harker (1943a, 1943b, 1943c, 1944a, 1944b), Harker and Bernhagen (1943a, 1943b, 1943c), Van Tuyl (1947), Kazman (1949), Smith and White (1953), Stafford (1954), Walker (1959, 1962a, 1962b, 1969, 1991), Kaser (1960), Ohio Water Commission (1960), Thomas (1960), Schmidt (1962a, 1962b, 1978, 1994), Ohio Department of Natural Resources (1968), Ohio Drilling Company (1971), Walker and Crumley (1979), Walker and Schottenstein (1979), Crouch and others (1980), Sugar (1988), Walker and Jiang (1991), Walker and Stewart (1991), Eckstein and others (2001), U.S. Geological Survey (2005), Schumacher and others (undated a), Stamm and others (undated), Zoller and others (undated b)

Medina Soil Conservation District (1960), Prée (1962a, 1962c), Williams (1958) Ohio Department of Natural Resources (1971, 1974a, 1974b,1978b), Quilliam (1973), Northeast Ohio Four County Regional Planning and Development Organization (1975, 1985, 1999a, 1999b, 1999c, 2001a, 2001b, 2003, 2004, 2005), Ohio Environmental Protection Agency (1978, 1979, 2002d, 2006c), Johnson (1986), Gannett Fleming (2000), Office of Surface Mining (2000), Schultz (2000), Kleski Environmental Consulting (2001), Carroll County Regional Planning Commission (2004), Espinoza (2005), Muskingum River Basin Initiative (2005), Akin (2006), Moore (2006), Ohio State University Extension (2006), Parker and Webb (2006), Tuscarawas County Metropolitan Sewer District (2006), U.S. Environmental Protection Agency (2006a, 2006b, 2006c), Wayne County Planning Department (2006)

Denny (1988), Bauder (1994), Earth Action Partnership Inc. (2006), The Nature Conservancy (2006)

\begin{tabular}{lc}
\hline \multicolumn{1}{c}{ Aquatic biology } \\
\hline General & Ohio Department of Natural Resources (1972), Quilliam (1973), U.S. Department of Transportation (1974), Tobin \\
& and Youger (1979), Ohio Environmental Protection Agency (1994a, 1994b, 1994c, 1995a, 1996a, 1996b, 1996c, \\
& 1998a, 1998b, 2001, 2002a, 2003, 2005, 2006b), Hambrook and others (1999), Ohio River Valley Ecosystem \\
Team (2002a, 2002b), U.S. Fish and Wildlife Service (2009b) & \\
Microbiology & Kraatz (1941), Ohio Environmental Protection Agency (2006c), Weitzel and Bates (1981) \\
Macro-invertebrates & Hyland (1982), McShaffrey and Olive (1985), Barber and others (1997), Hambrook and others (1999), March \\
& (2002), Ohio Environmental Protection Agency (2002c), Northeast Ohio Four County Regional Planning and \\
& Development Organization (2003a, 2005), Huff Run Watershed Restoration Partnership (2006b)
\end{tabular}




\section{Aquatic biology-Continued}

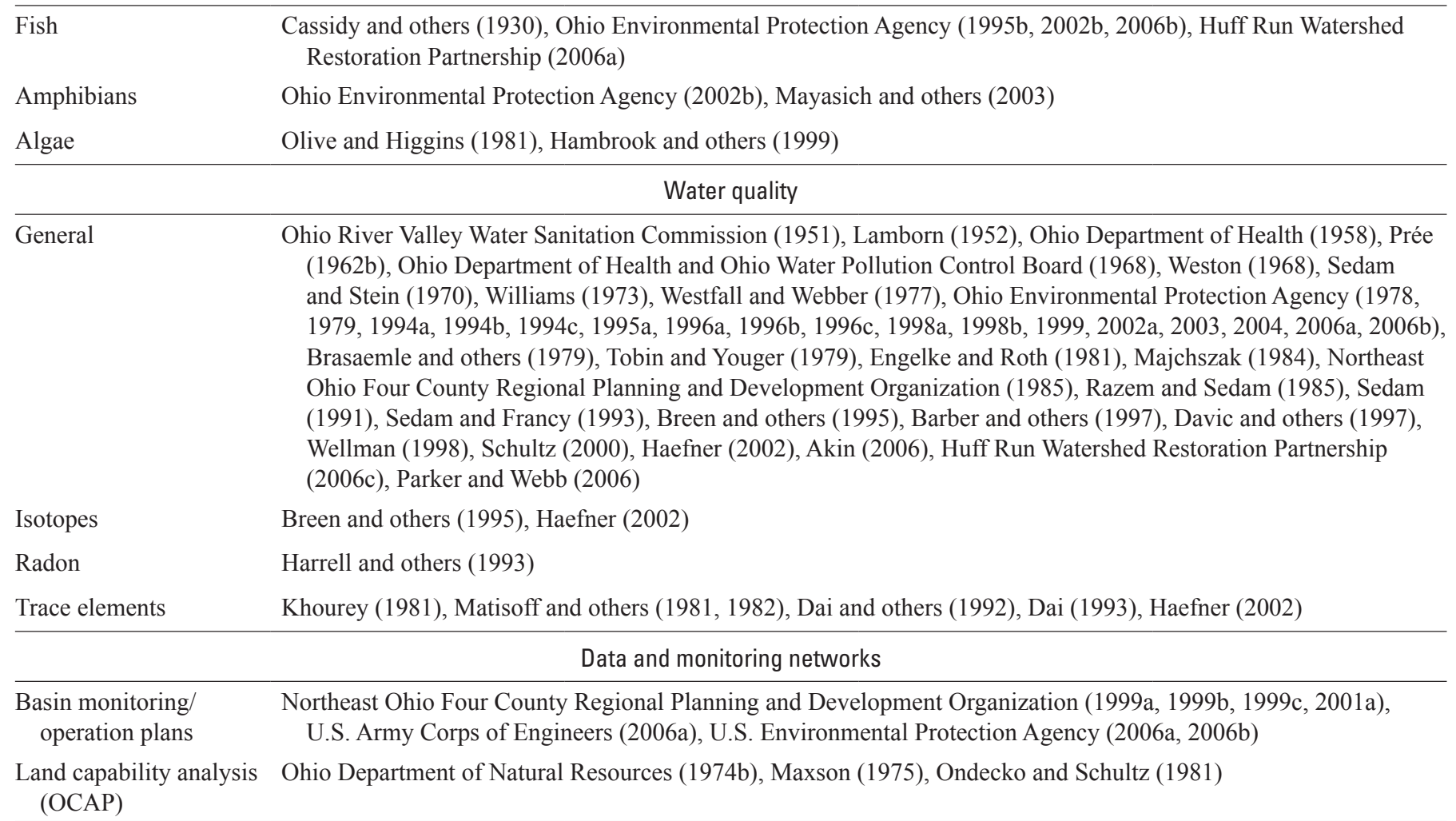




\section{Appendix 2. Results of Analyses of Water Samples Collected within the Tuscarawas River Basin, Ohio, 2006}

Abbreviations are as follows:

\begin{tabular}{|c|c|c|c|}
\hline - & not determined & $\mathrm{mg} / \mathrm{L}$ & milligrams per liter \\
\hline$>$ & greater than & $\mu \mathrm{g} / \mathrm{L}$ & micrograms per liter \\
\hline$<$ & less than & MI MF & $\begin{array}{l}\text { MI membrane filtration (MI is an abbreviation for } \\
\text { two different enzyme substrates) }\end{array}$ \\
\hline$(00000)$ & USGS parameter code & $\mathrm{mL}$ & milliliter \\
\hline ANC & acid neutralizing capacity & $\mathrm{mm}$ & millimeters \\
\hline $\mathrm{CaCO}_{3}$ & calcium carbonate & modif. mTEC & modified membrane thermotolerant E. coli \\
\hline $\mathrm{cc}$ & cubic centimeters & $\mu \mathrm{S} / \mathrm{cm}$ & microsiemens per centimeter at 25 degrees Celsius \\
\hline $\mathrm{cc} / \mathrm{L}$ & cubic centimeters per liter & $\mathrm{mV}$ & millivolts \\
\hline $\mathrm{CFC}$ & chlorofluorocarbon & NTU & nephelometric turbidity units \\
\hline $\mathrm{CSU}$ & combined standard uncertainty & $\mathrm{pg} / \mathrm{kg}$ & picograms per kilogram \\
\hline $\operatorname{deg} \mathrm{C}$ & degrees Celsius & pptv & parts per trillion by volume \\
\hline $\mathrm{E}$ & estimated & $\mathrm{pt}$ & point \\
\hline E. coli & Escherichia coliform & QA & quality assurance \\
\hline ext & extraction & RCnd & $\begin{array}{l}\text { radiochememical non-detect, below sample-specific } \\
\text { critical level }\end{array}$ \\
\hline $\mathrm{fg} / \mathrm{kg}$ & femtograms per kilogram & $\mathrm{Rj}$ & rejected sample \\
\hline $\mathrm{ft}$ & feet & ROE & residue on evaporation \\
\hline MF & membrane filtration & TU & tritium unit (equal to approximately $3.19 \mathrm{pCi} / \mathrm{L}$ ) \\
\hline $\mathrm{M}-\mathrm{FC}$ & membrane fecal coliform agar & unf & unfiltered \\
\hline
\end{tabular}




\begin{tabular}{|c|c|c|c|c|c|c|c|c|c|c|}
\hline Site & Date & Time & $\begin{array}{c}\text { Depth to } \\
\text { water, } \\
\text { ft below LSD } \\
\text { (72019) }\end{array}$ & $\begin{array}{c}\text { Stream } \\
\text { stage, } \\
\text { ft above } \\
\text { datum } \\
(00065)\end{array}$ & $\begin{array}{c}\text { Instan- } \\
\text { taneous } \\
\text { discharge, } \\
\mathrm{ft}^{3} / \mathbf{s} \\
(00061)\end{array}$ & $\begin{array}{l}\text { Flow rate, } \\
\text { instanta- } \\
\text { neous, } \\
\text { gal/min } \\
\text { (00059) }\end{array}$ & $\begin{array}{c}\text { Oxidation } \\
\text { reduction } \\
\text { potential, } \\
\text { field, } \\
\text { mV } \\
(00090)\end{array}$ & $\begin{array}{c}\text { Turbidity, } \\
\text { field, } \\
\text { NTU } \\
\text { (61028) }\end{array}$ & $\begin{array}{c}\text { Barometric } \\
\text { pressure, } \\
\text { field, } \\
\text { mm Hg } \\
(00025)\end{array}$ & $\begin{array}{c}\text { Oxygen, } \\
\text { dissolved, } \\
\text { field, } \\
\text { mg/L } \\
(00300)\end{array}$ \\
\hline \multicolumn{11}{|c|}{ Groundwater sites } \\
\hline B-3 & $7 / 20 / 2006$ & 1100 & 59.94 & - & - & 0.5 & 44.9 & 120 & 732 & 0.8 \\
\hline HR-44 & $7 / 17 / 2006$ & 930 & 22.00 & - & - & 25 & 118 & .2 & 742 & 1.4 \\
\hline MD-26 & $7 / 19 / 2006$ & 930 & - & - & - & 183 & -90.4 & .3 & 741 & .2 \\
\hline ST-27A & $7 / 24 / 2006$ & 1230 & 18.80 & - & - & 3 & -89.1 & .7 & 735 & .1 \\
\hline TU-113 & $7 / 25 / 2006$ & 1000 & 40.33 & - & - & 3 & -15.5 & 3.6 & 734 & .5 \\
\hline TU-184 & $7 / 18 / 2006$ & 900 & 12.30 & - & - & 1,550 & -21.7 & .2 & 740 & .9 \\
\hline TU-185 & $7 / 18 / 2006$ & 1400 & 55.00 & - & - & 350 & 21.5 & 1.0 & 744 & .7 \\
\hline \multicolumn{11}{|c|}{ Surface-water sites } \\
\hline TR@MA & $8 / 24 / 2006$ & 1430 & - & 0.62 & 105 & - & -1 & 8.3 & 738 & 5.7 \\
\hline TR@NCT & $8 / 24 / 2006$ & 1000 & - & 1.22 & 674 & - & 157 & 2.4 & 741 & 8.4 \\
\hline QA Blank & 7/19/2006 & 935 & - & - & - & - & - & - & 741 & - \\
\hline \multicolumn{11}{|c|}{ Suspended sediment } \\
\hline Site & Date & Time & $\begin{array}{c}\text { pH, } \\
\text { field, } \\
\text { std units } \\
(00400)\end{array}$ & $\begin{array}{c}\text { Concentra- } \\
\text { tion, } \\
\text { mg/L }\end{array}$ & $\begin{array}{c}\text { Percent } \\
<0.0625 \mathrm{~mm}\end{array}$ & $\begin{array}{c}\text { Specific } \\
\text { conduc- } \\
\text { tance, } \\
\text { field, } \\
\mu S / \mathrm{cm} \\
(00095)\end{array}$ & $\begin{array}{l}\text { Tempera- } \\
\text { ture, } \\
\text { air, field, } \\
\text { deg C } \\
\text { (00020) }\end{array}$ & $\begin{array}{c}\text { Tempera- } \\
\text { ture, } \\
\text { water, } \\
\text { field, } \\
\text { deg C } \\
\text { (00010) }\end{array}$ & $\begin{array}{c}\text { Hardness as } \\
\mathrm{CaCO}_{3^{\prime}} \\
\mathrm{mg} / \mathrm{L} \\
(00900)\end{array}$ & $\begin{array}{c}\text { Calcium, } \\
\text { mg/L } \\
(00915)\end{array}$ \\
\hline \multicolumn{11}{|c|}{ Groundwater sites } \\
\hline B-3 & $7 / 20 / 2006$ & 1100 & 8.4 & - & - & 701 & - & 18.7 & 30 & 8.97 \\
\hline HR-44 & $7 / 17 / 2006$ & 930 & 7.1 & - & - & 381 & 27.0 & 12.3 & 195 & 57.1 \\
\hline MD-26 & $7 / 19 / 2006$ & 930 & 6.5 & - & - & 443 & 28.0 & 13.0 & 197 & 52.1 \\
\hline ST-27A & $7 / 24 / 2006$ & 1230 & 7.1 & - & - & 1,200 & - & 12.9 & 466 & 136 \\
\hline TU-113 & $7 / 25 / 2006$ & 1000 & 5.5 & - & - & 2,680 & 30.0 & 14.1 & 1,540 & 352 \\
\hline TU-184 & $7 / 18 / 2006$ & 900 & 7.5 & - & - & 779 & 31.0 & 13.8 & 395 & 114 \\
\hline TU-185 & $7 / 18 / 2006$ & 1400 & 7.3 & - & - & 654 & 29.0 & 12.5 & 332 & 98.1 \\
\hline \multicolumn{11}{|c|}{ Surface-water sites } \\
\hline TR@MA & $8 / 24 / 2006$ & 1430 & 7.5 & 0.005 & 12 & 1,130 & 30.0 & 20.1 & 304 & 87.1 \\
\hline TR@NCT & $8 / 24 / 2006$ & 1000 & 8.2 & .001 & 3 & 992 & 30.0 & 22.7 & 325 & 88.3 \\
\hline QA Blank & $7 / 19 / 2006$ & 935 & - & - & - & - & 28.0 & - & - & E.0 \\
\hline
\end{tabular}




\begin{tabular}{|c|c|c|c|c|c|c|c|c|c|c|}
\hline Site & Date & Time & $\begin{array}{c}\text { Magnesium, } \\
\text { mg/L } \\
(00925)\end{array}$ & $\begin{array}{c}\text { Potassium, } \\
\mathrm{mg} / \mathrm{L} \\
(00935)\end{array}$ & $\begin{array}{l}\text { Sodium, } \\
\text { mg/L } \\
(00930)\end{array}$ & $\begin{array}{c}\text { ANC, unf, } \\
\text { fixed end pt, } \\
\text { lab, } \\
\text { mg/L as } \\
\mathrm{CaCO}_{3} \\
(90410)\end{array}$ & $\begin{array}{l}\text { Alkalinity, } \\
\text { incrm titr, } \\
\text { field, } \\
\mathrm{mg} / \mathrm{L} \text { as } \\
\mathrm{CaCO}_{3} \\
(39086)\end{array}$ & $\begin{array}{c}\text { Acidity, } \\
\text { total as } \\
\mathrm{CaCO}_{3^{\prime}} \\
\mathrm{mg} / \mathrm{L} \\
(00435)\end{array}$ & $\begin{array}{c}\text { Bicarbonate, } \\
\text { field, } \\
\text { mg/L } \\
(00453)\end{array}$ & $\begin{array}{l}\text { Carbonate, } \\
\text { incrm titr, } \\
\text { field, } \\
\text { mg/L } \\
(00452)\end{array}$ \\
\hline \multicolumn{11}{|c|}{ Groundwater sites } \\
\hline B-3 & $7 / 20 / 2006$ & 1100 & 1.8 & 1.39 & 147 & 297 & 302 & - & 359 & 5 \\
\hline HR-44 & $7 / 17 / 2006$ & 930 & 12.7 & 2.19 & 9.33 & 184 & 180 & - & 219 & .0 \\
\hline MD-26 & $7 / 19 / 2006$ & 930 & 16.1 & 1.74 & 5.47 & 119 & 181 & - & 220 & .0 \\
\hline ST-27A & $7 / 24 / 2006$ & 1230 & 30.7 & 2.17 & 62.5 & 296 & 302 & - & 368 & .0 \\
\hline TU-113 & $7 / 25 / 2006$ & 1000 & 160 & 7.75 & 9.81 & 63 & 99 & 335 & 120 & .0 \\
\hline TU-184 & $7 / 18 / 2006$ & 900 & 27 & 2.37 & 13.3 & 190 & 187 & - & 228 & .0 \\
\hline TU-185 & $7 / 18 / 2006$ & 1400 & 21.1 & 1.68 & 14.2 & 281 & 276 & - & 336 & .0 \\
\hline \multicolumn{11}{|c|}{ Surface-water sites } \\
\hline TR@MA & $8 / 24 / 2006$ & 1430 & 21 & 5.04 & 101 & 186 & 185 & - & 223 & 1 \\
\hline TR@NCT & $8 / 24 / 2006$ & 1000 & 25.4 & 5.12 & 66.2 & 164 & 165 & - & 196 & 2 \\
\hline QA Blank & $7 / 19 / 2006$ & 935 & E. 0 & $<.2$ & $<.2$ & $<5$ & - & - & - & - \\
\hline Site & Date & Time & $\begin{array}{c}\text { Bromide, } \\
\text { mg/L } \\
(71870)\end{array}$ & $\begin{array}{c}\text { Chloride, } \\
\text { mg/L } \\
(00940)\end{array}$ & $\begin{array}{c}\text { Fluoride, } \\
\text { mg/L } \\
(00950)\end{array}$ & $\begin{array}{l}\text { Silica, } \\
\text { mg/L } \\
(00955)\end{array}$ & $\begin{array}{c}\text { Sulfate, } \\
\text { field, } \\
\text { mg/L } \\
(99113)\end{array}$ & $\begin{array}{c}\text { Sulfate, } \\
\text { mg/L } \\
(00945)\end{array}$ & $\begin{array}{c}\text { Sulfide, } \\
\text { field, } \\
\text { mg/L } \\
(99118)\end{array}$ & $\begin{array}{c}\text { Residue, } \\
\text { ROE at } \\
180 \mathrm{deg} C \text {, } \\
\mathrm{mg} / \mathrm{L} \\
(70300)\end{array}$ \\
\hline \multicolumn{11}{|c|}{ Groundwater sites } \\
\hline B-3 & $7 / 20 / 2006$ & 1100 & $<0.02$ & 16.1 & 0.38 & 11.6 & 66 & 55.9 & 0.002 & 422 \\
\hline HR-44 & $7 / 17 / 2006$ & 930 & .03 & 6.72 & .22 & 10.9 & 19 & 29.6 & .002 & 240 \\
\hline MD-26 & $7 / 19 / 2006$ & 930 & E.02 & 9.21 & .17 & 11.2 & 30 & 76.4 & .009 & 265 \\
\hline ST-27A & $7 / 24 / 2006$ & 1230 & $<.02$ & 175 & .12 & 13.3 & 70 & 78.7 & .012 & 691 \\
\hline TU-113 & $7 / 25 / 2006$ & 1000 & .18 & 3.09 & Е.07 & 13.3 & 1,600 & 1,690 & .019 & 2,740 \\
\hline TU-184 & $7 / 18 / 2006$ & 900 & .07 & 34.2 & Е.09 & 11.3 & 180 & 174 & .003 & 534 \\
\hline TU-185 & $7 / 18 / 2006$ & 1400 & .10 & 19.1 & .13 & 11.6 & 46 & 46.5 & .005 & 394 \\
\hline \multicolumn{11}{|c|}{ Surface-water sites } \\
\hline TR@MA & $8 / 24 / 2006$ & 1430 & .12 & 206 & .26 & 7.26 & 62 & 74.3 & .005 & 675 \\
\hline TR@NCT & Г 8/24/2006 & 1000 & .13 & 119 & .32 & 3.58 & 80 & 157 & .009 & 605 \\
\hline QA Blank & 7/19/2006 & 935 & $<.02$ & $<.2$ & $<.1$ & $<.04$ & - & $<.2$ & - & $<10$ \\
\hline
\end{tabular}




\begin{tabular}{|c|c|c|c|c|c|c|c|c|c|c|}
\hline Site & Date & Time & $\begin{array}{c}\text { Ammonia + } \\
\text { organic } \\
\text { nitrogen, } \\
\text { mg/L } \\
(00623)\end{array}$ & $\begin{array}{c}\text { Ammonia, } \\
\text { mg/L } \\
(00608)\end{array}$ & $\begin{array}{c}\text { Nitrite + } \\
\text { nitrate, } \\
\text { mg/L } \\
(00631)\end{array}$ & $\begin{array}{c}\text { Nitrite, } \\
\text { mg/L } \\
(00613)\end{array}$ & $\begin{array}{c}\text { Nitrate, } \\
\text { calculated, } \\
\text { mg/L }\end{array}$ & $\begin{array}{l}\text { Orthophos- } \\
\text { phate, } \\
\text { mg/L } \\
(00671)\end{array}$ & $\begin{array}{c}\text { Phosphorus, } \\
\text { mg/L } \\
(00666)\end{array}$ & $\begin{array}{c}\text { Organic } \\
\text { carbon, } \\
\text { dissolved, } \\
\text { mg/L } \\
\text { (00681) }\end{array}$ \\
\hline \multicolumn{11}{|c|}{ Groundwater sites } \\
\hline B-3 & $7 / 20 / 2006$ & 1100 & 0.24 & 0.141 & 0.81 & 0.003 & 0.81 & 0.067 & 0.05 & 1.0 \\
\hline HR-44 & $7 / 17 / 2006$ & 930 & E.10 & $<.010$ & .14 & $<.002$ & .14 & E.006 & $<.04$ & .6 \\
\hline MD-26 & $7 / 19 / 2006$ & 930 & E. 10 & .056 & $<.06$ & $<.002$ & $<.06$ & $<.018$ & $<.04$ & .4 \\
\hline ST-27A & $7 / 24 / 2006$ & 1230 & .88 & .727 & $<.06$ & $<.002$ & $<.06$ & .008 & E.02 & 1.5 \\
\hline TU-113 & $7 / 25 / 2006$ & 1000 & .53 & .399 & $<.06$ & $<.002$ & $<.06$ & $<.006$ & E.03 & 2.1 \\
\hline TU-184 & $7 / 18 / 2006$ & 900 & .10 & .025 & .57 & E. 002 & .57 & E.006 & $<.04$ & .5 \\
\hline TU-185 & $7 / 18 / 2006$ & 1400 & .21 & .159 & 1.81 & E. .002 & 1.81 & .011 & $<.04$ & .7 \\
\hline \multicolumn{11}{|c|}{ Surface-water sites } \\
\hline TR@MA & $8 / 24 / 2006$ & 1430 & .48 & .049 & 1.37 & .017 & 1.35 & .371 & .4 & 4.4 \\
\hline TR@NCT & $8 / 24 / 2006$ & 1000 & .41 & $<.010$ & 1.44 & .005 & 1.44 & .135 & .15 & 3.0 \\
\hline QA Blank & $7 / 19 / 2006$ & 935 & E. 06 & $<.01$ & $<.06$ & $<.002$ & $<.06$ & $<.006$ & $<.04$ & $<.33$ \\
\hline
\end{tabular}

${ }^{1}$ Nitrate calculated as the difference between the two previous columns [(nitrite + nitrate $)$ - nitrite $]$.

\begin{tabular}{|c|c|c|c|c|c|c|c|c|c|c|}
\hline Site & Date & Time & $\begin{array}{c}\text { E. coli, } \\
\text { MI MF, } \\
\text { col/100 mL } \\
(90901)\end{array}$ & $\begin{array}{c}\text { E. coli, } \\
\text { modif. } \\
\text { m-TEC, } \\
\text { col/100 mL }\end{array}$ & $\begin{array}{c}\text { Fecal coli- } \\
\text { form, M-FC } \\
0.45 \mathrm{~m} \mathrm{MF} \\
\text { col } / 100 \mathrm{~mL}\end{array}$ & $\begin{array}{l}\text { Total coli- } \\
\text { form, MI MF, } \\
\text { col/100 mL } \\
(90900)\end{array}$ & $\begin{array}{c}\text { Aluminum, } \\
\text { dissolved, } \\
\mu \mathrm{g} / \mathrm{L} \\
(01106)\end{array}$ & $\begin{array}{c}\text { Aluminum, } \\
\text { total, } \\
\mu \mathrm{g} / \mathrm{L} \\
(01105)\end{array}$ & $\begin{array}{c}\text { Argon gas, } \\
\mathrm{mg} / \mathrm{L} \\
(82043)\end{array}$ & $\begin{array}{c}\text { Arsenic, } \\
\mu \mathrm{g} / \mathrm{L} \\
(01000)\end{array}$ \\
\hline
\end{tabular}

Groundwater sites

\begin{tabular}{lrrrrrrrrrr}
\hline B-3 & $7 / 20 / 2006$ & 1100 & E 5 & - & E 5 & $>80$ & 11.8 & 1,620 & 0.727 & 3.8 \\
HR-44 & $7 / 17 / 2006$ & 930 & $<1$ & - & $<1$ & E 3 & $<1.6$ & E 1 & .744 & $<.12$ \\
MD-26 & $7 / 19 / 2006$ & 930 & $<1$ & - & $<1$ & $<1$ & 10 & 19 & .786 & .67 \\
ST-27A & $7 / 24 / 2006$ & 1230 & $<1$ & - & $<1$ & $<1$ & $<1.6$ & E 2 & .696 & 4.0 \\
TU-113 & $7 / 25 / 2006$ & 1000 & $<1$ & - & $<1$ & E 110 & 17.4 & 31 & .914 & .34 \\
TU-184 & $7 / 18 / 2006$ & 900 & $<1$ & - & $<1$ & $<1$ & $<1.6$ & $<2$ & .685 & 3.0 \\
TU-185 & $7 / 18 / 2006$ & 1400 & $<1$ & - & $<1$ & E 1 & $<1.6$ & $<2$ & .727 & .16 \\
\hline & & & & & Surface-water sites & & & & 3.9 \\
\hline TR@MA & $8 / 24 / 2006$ & 1430 & - & 100 & 157 & - & 5.1 & 140 & - & 1.6 \\
TR@NCT 8/24/2006 & 1000 & - & 61 & E 47 & - & 8.9 & 60 & - & $<.1$ \\
QA Blank 7/19/2006 & 935 & $<1$ & $<1$ & $<1$ & $<1$ & $<1.6$ & $<2$ & - & $<$
\end{tabular}




\begin{tabular}{|c|c|c|c|c|c|c|c|c|c|c|}
\hline Site & Date & Time & $\begin{array}{c}\text { Boron, } \\
\mu \mathrm{g} / \mathrm{L} \\
(01020)\end{array}$ & $\begin{array}{c}\text { Cadmium, } \\
\mu \mathrm{g} / \mathrm{L} \\
(01025)\end{array}$ & $\begin{array}{c}\text { Chromium, } \\
\mu \mathrm{g} / \mathrm{L} \\
(01030)\end{array}$ & $\begin{array}{c}\text { Cobalt, } \\
\mu \mathrm{g} / \mathrm{L} \\
(01035)\end{array}$ & $\begin{array}{c}\text { Copper, } \\
\mu \mathrm{g} / \mathrm{L} \\
(01040)\end{array}$ & $\begin{array}{c}\text { Iron (II), } \\
\text { field, } \\
\mathrm{mg} / \mathrm{L} \\
(99114)\end{array}$ & $\begin{array}{c}\text { Iron, total, } \\
\text { field, } \\
\text { mg/L } \\
(99115)\end{array}$ & $\begin{array}{c}\text { Iron, } \\
\text { dissolved } \\
\mu \mathrm{g} / \mathrm{L} \\
(\mathbf{0 1 0 4 6 )}\end{array}$ \\
\hline
\end{tabular}

\begin{tabular}{lrrrrrrrrrr}
\hline \multicolumn{10}{c}{ Groundwater sites } \\
\hline B-3 & $7 / 20 / 2006$ & 1100 & 330 & $<2$ & $<2$ & $<2$ & 2 & 0.000 & 0.010 & 8 \\
HR-44 & $7 / 17 / 2006$ & 930 & 48 & $<2$ & E 1 & $<2$ & $<2$ & .000 & .010 & $<6$ \\
MD-26 & $7 / 19 / 2006$ & 930 & 21 & $<2$ & E 1 & 13 & $<2$ & 10.1 & 8.20 & 11,100 \\
ST-27A & $7 / 24 / 2006$ & 1230 & 25 & $<2$ & 2 & $<2$ & $<2$ & 2.74 & 2.10 & 3,310 \\
TU-113 & $7 / 25 / 2006$ & 1000 & 188 & $<6$ & 6 & 112 & $<6$ & 168 & 165 & 173,000 \\
TU-184 & $7 / 18 / 2006$ & 900 & 34 & $<2$ & E 1 & $<2$ & $<2$ & .140 & .150 & 151 \\
TU-185 & $7 / 18 / 2006$ & 1400 & 37 & $<2$ & E 1 & $<2$ & E 2 & .020 & .090 & 97 \\
\hline & & & & & Surface-water sites & & & & 37 \\
\hline TR@MA & $8 / 24 / 2006$ & 1430 & 101 & $<2$ & E2 & $<2$ & $<2$ & .000 & .040 & 37 \\
TR@NCT 8/24/2006 & 1000 & 98 & $<2$ & E 2 & $<2$ & $<2$ & .000 & .000 & 14 \\
QA Blank 7/19/2006 & 935 & $<7$ & $<2$ & $<2$ & $<2$ & $<2$ & - & - & $<6$
\end{tabular}

\begin{tabular}{|c|c|c|c|c|c|c|c|c|c|c|}
\hline Site & Date & Time & $\begin{array}{c}\text { Iron, } \\
\text { total, } \\
\mu \mathrm{g} / \mathrm{L} \\
(01045)\end{array}$ & $\begin{array}{c}\text { Lead, } \\
\mu \mathrm{g} / \mathrm{L} \\
(01049)\end{array}$ & $\begin{array}{c}\text { Lithium, } \\
\mu \mathrm{g} / \mathrm{L} \\
(01130)\end{array}$ & $\begin{array}{c}\text { Manganese, } \\
\text { dissolved, } \\
\mu \mathrm{g} / \mathrm{L} \\
(01056)\end{array}$ & $\begin{array}{c}\text { Manganese, } \\
\text { total, } \\
\mu \mathrm{g} / \mathrm{L} \\
(01055)\end{array}$ & $\begin{array}{c}\text { Mercury, } \\
\mu \mathrm{gg} / \mathrm{L} \\
(\mathbf{7 1 8 9 0})\end{array}$ & $\begin{array}{c}\text { Molyb- } \\
\text { denum, } \\
\mu \mathrm{g} / \mathrm{L} \\
(01060)\end{array}$ & $\begin{array}{c}\text { Nickel, } \\
\mu \mathrm{g} / \mathrm{L} \\
(01065)\end{array}$ \\
\hline
\end{tabular}

\begin{tabular}{|c|c|c|c|c|c|c|c|c|c|c|}
\hline \multicolumn{11}{|c|}{ Groundwater sites } \\
\hline B-3 & $7 / 20 / 2006$ & 1100 & 2,780 & 0.48 & 23 & 4.1 & 61.2 & $<0.010$ & E 3 & 2 \\
\hline HR-44 & $7 / 17 / 2006$ & 930 & $<6$ & .76 & 20 & $<.6$ & $<.6$ & $<.010$ & E 4 & $<2$ \\
\hline MD-26 & 7/19/2006 & 930 & 12,200 & $<.08$ & 15 & 1,420 & 1,390 & $<.010$ & 4 & 34 \\
\hline ST-27A & $7 / 24 / 2006$ & 1230 & 3,860 & $<.08$ & 11 & 150 & 148 & $<.010$ & 6 & $<2$ \\
\hline TU-113 & $7 / 25 / 2006$ & 1000 & 161,000 & $<.16$ & 220 & 9,060 & 8,080 & $<.010$ & 15 & 250 \\
\hline TU-184 & $7 / 18 / 2006$ & 900 & 151 & .15 & 5 & 293 & 291 & $<.010$ & 5 & $<2$ \\
\hline TU-185 & $7 / 18 / 2006$ & 1400 & 98 & E.06 & 4 & 221 & 221 & $<.010$ & 5 & $<2$ \\
\hline \multicolumn{11}{|c|}{ Surface-water sites } \\
\hline TR@MA & $8 / 24 / 2006$ & 1430 & 394 & .10 & 12 & 194 & 216 & $<.010$ & 9 & $<2$ \\
\hline TR@NCT & $8 / 24 / 2006$ & 1000 & 164 & .08 & 12 & 29.6 & 53.4 & $<.010$ & 9 & $<2$ \\
\hline QA Blank & $7 / 19 / 2006$ & 935 & $<6$ & $<.08$ & $<2.0$ & $<.6$ & $<.6$ & $<.010$ & $<4.0$ & $<2$ \\
\hline
\end{tabular}




\begin{tabular}{|c|c|c|c|c|c|c|c|c|c|c|}
\hline Site & Date & Time & $\begin{array}{c}\text { Selenium, } \\
\mu \mathrm{g} / \mathrm{L} \\
(01145)\end{array}$ & $\begin{array}{c}\text { Silver, } \\
\mu \mathrm{g} / \mathrm{L} \\
(01075)\end{array}$ & $\begin{array}{c}\text { Strontium, } \\
\mu \mathrm{g} / \mathrm{L} \\
(01080)\end{array}$ & $\begin{array}{c}\text { Vanadium, } \\
\mu \mathrm{g} / \mathrm{L} \\
(01085)\end{array}$ & $\begin{array}{c}\text { Zinc, } \\
\mu \mathrm{g} / \mathrm{L} \\
(01090)\end{array}$ & $\begin{array}{c}\text { Petroleum } \\
\text { hydrocar- } \\
\text { bons, } \\
\text { freon ext, } \\
\mathrm{mg} / \mathrm{L} \\
\text { (45501) }\end{array}$ & $\begin{array}{l}\text { Alpha } \\
\text { emitting } \\
\text { radium, } \\
\mathrm{pCi} / \mathrm{L} \\
(09510)\end{array}$ & $\begin{array}{l}\text { Alpha } \\
\text { emitting } \\
\text { radium, } \\
\text { 1-sigma } \\
\text { CSU, } \\
\text { pCi/L }\end{array}$ \\
\hline \multicolumn{11}{|c|}{ Groundwater sites } \\
\hline B-3 & $7 / 20 / 2006$ & 1100 & Е .07 & $<3$ & 152 & $<2$ & $<6$ & $<2$ & Rnd 0.000 & 0.010 \\
\hline HR-44 & $7 / 17 / 2006$ & 930 & .87 & $<3$ & 467 & $<2$ & 32 & $<2$ & .050 & .019 \\
\hline MD-26 & $7 / 19 / 2006$ & 930 & $<.08$ & $<3$ & 98.9 & $<2$ & 96 & $<2$ & .56 & .042 \\
\hline ST-27A & $7 / 24 / 2006$ & 1230 & $<.08$ & $<3$ & 226 & $<2$ & $<6$ & $<2$ & .87 & .050 \\
\hline TU-113 & $7 / 25 / 2006$ & 1000 & .16 & $<8$ & 1,210 & $<6$ & 69 & $<2$ & 1.9 & .170 \\
\hline TU-184 & $7 / 18 / 2006$ & 900 & .67 & $<3$ & 145 & $<2$ & $<6$ & - & .16 & .026 \\
\hline TU-185 & $7 / 18 / 2006$ & 1400 & .17 & $<3$ & 174 & $<2$ & E 6 & $<2$ & .107 & .019 \\
\hline \multicolumn{11}{|c|}{ Surface-water sites } \\
\hline TR@MA & $8 / 24 / 2006$ & 1430 & .14 & $<3$ & 288 & E 1 & $<6$ & $<2$ & .082 & .017 \\
\hline TR@NCT & $8 / 24 / 2006$ & 1000 & .21 & $<3$ & 292 & $<2$ & $<6$ & $<2$ & Rnd .01 & .025 \\
\hline QA Blank & $7 / 19 / 2006$ & 935 & $<.08$ & $<3$ & $<1.0$ & $<2$ & $<6$ & $<2$ & -.027 & .010 \\
\hline Site & Date & Time & $\begin{array}{c}\text { Deuterium/ } \\
\text { protium } \\
\left({ }^{2} \mathrm{H} /{ }^{\prime} \mathrm{H}\right) \text { ratio, } \\
\text { per mil } \\
\text { (82082) }\end{array}$ & $\begin{array}{c}\text { Radon-222, } \\
\text { pCi/L } \\
(\mathbf{8 2 3 0 3 )}\end{array}$ & $\begin{array}{c}\text { Radon-222, } \\
\text { 2-sigma } \\
\text { precision } \\
\text { estimate, } \\
\text { pCi/L } \\
(76002)\end{array}$ & $\begin{array}{c}\text { Uranium, } \\
\mu \mathrm{g} / \mathrm{L} \\
(22703)\end{array}$ & $\begin{array}{l}\text { Uranium, } \\
1 \sigma \mathrm{CSU}\end{array}$ & $\begin{array}{c}{ }^{18} 0 /{ }^{16} 0 \text { ratio, } \\
\text { per mil } \\
\text { (82085) }\end{array}$ & $\begin{array}{l}\text { Excess air, } \\
\quad \text { cc/L }\end{array}$ & $\begin{array}{c}\text { Recharge } \\
\text { temperature, } \\
\text { deg C }\end{array}$ \\
\hline \multicolumn{11}{|c|}{ Groundwater sites } \\
\hline B-3 & $7 / 20 / 2006$ & 1100 & -53.10 & 390 & 21 & 0.31 & 0.023 & -8.40 & 4.5 & 10.8 \\
\hline HR-44 & $7 / 17 / 2006$ & 930 & -51.70 & 1,930 & 43 & .34 & .025 & -8.00 & 4.8 & 10.4 \\
\hline MD-26 & $7 / 19 / 2006$ & 930 & -60.50 & 180 & 20 & .114 & .016 & -9.27 & 5.5 & 8.0 \\
\hline ST-27A & $7 / 24 / 2006$ & 1230 & -56.30 & 190 & 18 & .246 & .019 & -8.73 & 4.7 & 12.8 \\
\hline TU-113 & $7 / 25 / 2006$ & 1000 & -54.20 & 30 & 14 & Rnd .000 & .004 & -8.39 & 2.0 & 11.0 \\
\hline TU-184 & $7 / 18 / 2006$ & 900 & -51.50 & 240 & 19 & .42 & .03 & -7.86 & 4.4 & 13.5 \\
\hline TU-185 & $7 / 18 / 2006$ & 1400 & -54.00 & 330 & 20 & .32 & .023 & -8.28 & 5.8 & 12.5 \\
\hline \multicolumn{11}{|c|}{ Surface-water sites } \\
\hline TR@MA & $8 / 24 / 2006$ & 1430 & -45.10 & - & - & .86 & .061 & -6.69 & - & - \\
\hline TR@NCT & $8 / 24 / 2006$ & 1000 & -46.90 & - & - & .80 & .057 & -7.17 & - & - \\
\hline QA Blank & $7 / 19 / 2006$ & 935 & - & - & - & 0 & .004 & - & - & - \\
\hline
\end{tabular}




\begin{tabular}{|c|c|c|c|c|c|c|c|c|c|}
\hline Site & Date & Time & $\begin{array}{c}\text { Sulfur hexa- } \\
\text { fluoride, } \\
\text { fg/kg } \\
(63149)\end{array}$ & $\begin{array}{c}\text { Sulfur hexa- } \\
\text { fluoride par- } \\
\text { tial pressure, } \\
\text { corrected for } \\
\text { excess air, } \\
\text { pptv }\end{array}$ & $\begin{array}{l}\text { PFM } \\
\text { sulfurhexa- } \\
\text { fluoride } \\
\text { recharge } \\
\text { year }\end{array}$ & $\begin{array}{l}\text { Trifluoro- } \\
\text { methylsul- } \\
\text { furpenta- } \\
\text { fluoride, } \\
\text { pptv }\end{array}$ & $\begin{array}{l}\text { PFM trifluo- } \\
\text { romethyl- } \\
\text { sulfurpen- } \\
\text { tafluoride } \\
\text { recharge } \\
\text { year }\end{array}$ & $\begin{array}{l}\text { Tritium, } \\
\text { TU }\end{array}$ & $\begin{array}{l}\text { Tritium error, } \\
1 \text { sigma TU }\end{array}$ \\
\hline \multicolumn{10}{|c|}{ Groundwater sites } \\
\hline B-3 & $7 / 20 / 2006$ & 1100 & 315 & 3.84 & 1996.5 & - & - & 2.39 & 0.05 \\
\hline HR-44 & $7 / 17 / 2006$ & 930 & 231 & 2.66 & 1991.3 & 0.081 & 1991.5 & 7.28 & .15 \\
\hline MD-26 & $7 / 19 / 2006$ & 930 & 79.0 & 1.29 & 1978.8 & .012 & 1974.5 & 2.11 & .04 \\
\hline ST-27A & $7 / 24 / 2006$ & 1230 & 70.6 & 0.97 & 1981.0 & .007 & 1971.5 & 8.75 & .18 \\
\hline TU-113 & $7 / 25 / 2006$ & 1000 & .00 & 0 & $<1952.0$ & 0 & $<1965.0$ & 8.76 & .18 \\
\hline TU-184 & $7 / 18 / 2006$ & 900 & 97.6 & 1.29 & 1983.5 & .083 & 1991.8 & 7.06 & .17 \\
\hline TU-185 & $7 / 18 / 2006$ & 1400 & 116 & 1.18 & 1982.8 & .025 & 1979.3 & 2.86 & .135 \\
\hline \multicolumn{10}{|c|}{ Surface-water sites } \\
\hline TR@MA & $8 / 24 / 2006$ & 1430 & - & - & - & - & - & - & - \\
\hline TR@NCT & $8 / 24 / 2006$ & 1000 & - & - & - & - & - & - & - \\
\hline QA Blank & $7 / 19 / 2006$ & 935 & - & - & - & - & - & - & - \\
\hline
\end{tabular}

\begin{tabular}{|c|c|c|c|c|c|c|c|c|}
\hline Site & Date & Time & $\begin{array}{c}\text { Delta } \\
\text { helium-3, } \\
\text { percent }\end{array}$ & $\begin{array}{l}\text { Helium-4, } \\
\text { cc STP/g } \\
\times 10^{-8}\end{array}$ & $\begin{array}{c}\text { Neon, } \\
\text { measured, } \\
\text { cc STP/g } \\
\times 10^{-7}\end{array}$ & $\begin{array}{c}\text { Helium-4, } \\
\text { terrigenic, } \\
\text { percent }\end{array}$ & $\begin{array}{c}\text { Tritium-helium-3 } \\
\text { recharge year, } \\
\text { with terrigenic } \\
\text { helium } \\
\text { correction, } \\
\text { years }\end{array}$ & $\begin{array}{l}\text { Tritium-helium-3 } \\
\text { recharge year, } \\
\text { error with } \\
\text { terrigenic helium } \\
\text { correction, } \\
\text { years }\end{array}$ \\
\hline \multicolumn{9}{|c|}{ Groundwater sites } \\
\hline B-3 & $7 / 20 / 2006$ & 1100 & -10.94 & 6.424 & 21.460 & 17.0 & 1993.7 & \pm 0.2 \\
\hline HR-44 & 7/17/2006 & 930 & 1.75 & 7.014 & 23.769 & 17.3 & 1993.5 & \pm .2 \\
\hline MD-26 & $7 / 19 / 2006$ & 930 & -28.96 & 10.368 & 24.146 & 43.1 & 1977.9 & \pm .3 \\
\hline ST-27A & $7 / 24 / 2006$ & 1230 & -100.15 & 34.319 & 23.128 & 83.6 & $\mathrm{Rj}$ & - \\
\hline TU-113 & $7 / 25 / 2006$ & 1000 & 4.00 & 7.465 & 23.863 & 21.2 & 1992.1 & \pm .2 \\
\hline TU-184 & $7 / 18 / 2006$ & 900 & -59.87 & 16.632 & 21.654 & 68.5 & 1993.5 & \pm .2 \\
\hline TU-185 & $7 / 18 / 2006$ & 1400 & -86.96 & 14.016 & 22.180 & 61.7 & $\mathrm{Rj}$ & - \\
\hline \multicolumn{9}{|c|}{ Surface-water sites } \\
\hline TR@MA & $8 / 24 / 2006$ & 1430 & - & - & - & - & - & - \\
\hline TR@NCT & $8 / 24 / 2006$ & 1000 & - & - & - & - & - & - \\
\hline QA Blank & $7 / 19 / 2006$ & 935 & - & - & - & - & - & - \\
\hline
\end{tabular}


CFC concentration in solution, $\mathrm{pg} / \mathrm{kg}$

CFC partial pressure,

corrected for excess air, pptv

Site Date Time CFC-11 CFC-12 CFC-113 $\quad$ CFC-11 $\quad$ CFC-12 $\quad$ CFC-113

\begin{tabular}{lrrrrrrrr}
\hline \multicolumn{7}{c}{ Groundwater sites } \\
\hline B-3 & $7 / 20 / 2006$ & 1100 & 42.0 & 58.5 & 7.4 & 15.9 & 93.6 & 6.5 \\
HR-44 & $7 / 17 / 2006$ & 930 & $9,905.7$ & $1,187.1$ & 22.2 & $3,610.0$ & $1,830.0$ & 18.8 \\
MD-26 & $7 / 19 / 2006$ & 930 & 12.0 & 61.2 & 3.0 & 3.8 & 84.5 & 2.2 \\
ST-27A & $7 / 24 / 2006$ & 1230 & 8.2 & 4.8 & .0 & 3.4 & 8.3 & .0 \\
TU-113 & $7 / 25 / 2006$ & 1000 & 4.9 & 4.4 & .0 & 1.9 & 7.1 & .0 \\
TU-184 & $7 / 18 / 2006$ & 900 & 267.3 & 588.8 & $1,266.4$ & 115.0 & $1,050.0$ & $1,280.0$ \\
TU-185 & $7 / 18 / 2006$ & 1400 & 86.8 & 86.1 & 2.7 & 35.4 & 146.0 & 2.6 \\
\hline
\end{tabular}

Surface-water sites

TR@MA 8/24/2006 1430

TR@NCT 8/24/20061000

QA Blank 7/19/2006 935

PFM CFC recharge year

Site Date Time CFC-11 CFC-12 CFC-113 Argon Oxygen $\begin{gathered}\text { Carbon } \\ \text { dioxide }\end{gathered}$ Nitrogen Methane
Concentration dissolved in water, in $\mathrm{mg} / \mathrm{L}$ as measured at USGS Reston Dissolved Gas Laboratory

\begin{tabular}{|c|c|c|c|c|c|c|c|c|c|c|}
\hline \multicolumn{11}{|c|}{ Groundwater sites } \\
\hline B-3 & $7 / 20 / 2006$ & 1100 & 1962.0 & 1967.2 & 1970.5 & 0.720 & 0.25 & 2.11 & 21.6 & 0.000 \\
\hline HR-44 & $7 / 17 / 2006$ & 930 & $\mathrm{C}$ & $\mathrm{C}$ & 1978.3 & .740 & .72 & 25.4 & 22.2 & 0 \\
\hline MD-26 & $7 / 19 / 2006$ & 930 & 1955.0 & 1966.5 & 1963.0 & .783 & .30 & 79.7 & 23.7 & .018 \\
\hline ST-27A & $7 / 24 / 2006$ & 1230 & 1954.8 & 1950.3 & 1953.0 & .699 & .25 & 37.3 & 23.1 & .167 \\
\hline TU-113 & $7 / 25 / 2006$ & 1000 & 1952.5 & 1949.5 & 1953.0 & .919 & .31 & 331 & 28.1 & .200 \\
\hline TU-184 & $7 / 18 / 2006$ & 900 & 1974.8 & $\mathrm{C}$ & $\mathrm{C}$ & .686 & .78 & 11.6 & 21.1 & .009 \\
\hline TU-185 & $7 / 18 / 2006$ & 1400 & 1966.3 & 1970.7 & 1964.0 & .722 & .26 & 29.8 & 22.3 & .004 \\
\hline \multicolumn{11}{|c|}{ Surface-water sites } \\
\hline TR@MA & $8 / 24 / 2006$ & 1430 & - & - & - & - & - & - & - & - \\
\hline TR@NCT & $8 / 24 / 2006$ & 1000 & - & - & - & - & - & - & - & - \\
\hline QA Blank & $7 / 19 / 2006$ & 935 & - & - & - & - & - & - & - & - \\
\hline
\end{tabular}




\section{Appendix 3. Glossary of Water-Quality Reporting Levels and Qualifiers}

In U.S. Geological Survey reports that include data from the National Water- Quality Laboratory, the following reporting levels and qualifiers are used to characterize water-quality data. These terms and concepts are further defined in Childress and others (1999), Bonn (2008), and U.S. Geological Survey (2008b). The following terms are listed in alphabetical order.

Estimated concentrations (denoted by an " $E$ " in data tables) are typically less than the LRL and greater than the LT-MDL and are derived from "information-rich" methods. Concentrations are still listed as detections in this report, but there is greater uncertainty associated with the calculated concentration.

Information-rich methods done with mass spectrometric or photodiode array ultraviolet/visible spectroscopic detectors and used for organic methods are classified by the National Water Quality Laboratory as information rich because they have enhanced analyte identification capabilities.

Interim reporting level (IRL) is used when a method does not have at least 1 year's worth of supporting data to determine an LT-MDL and an LRL. The IRL is based on an estimated detection limit and is set to at least two times that estimation.

Laboratory reporting level (LRL) is calculated by multiplying the LT-MDL by two so as to reduce the probability of a false negative to less than or equal to 1 percent.

Long-term method detection level (LT-MDL) is the smallest concentrations that can be measured and reported with 99 percent confidence that the analyte concentration is greater than zero.

Minimum reporting level (MRL) is the smallest measured concentration of an analyte that may be reliably reported by using a given analytical method (Timme, 1995).

\section{References}

Bonn, B.A., 2008, Using the U.S. Geological Survey National Water Quality Laboratory LT-MDL to evaluate and analyze data: U.S. Geological Survey Open-File Report 2008-1227, $73 \mathrm{p}$.

Childress, C.J.O., Foreman, W.T., Connor, B.F., and Maloney, T.J., 1999, New reporting procedures based on longterm method detection levels and some considerations for interpretations of water-quality data provided by the U.S. Geological Survey National Water Quality Laboratory: U.S. Geological Survey Open-File Report 99-193, 19 p.

Timme, P.J., 1995, National Water Quality Laboratory 1995 Services Catalog: U.S. Geological Survey Open-File Report 95-352, $92 \mathrm{p}$.

U.S. Geological Survey, 2008b, Long term-method detection levels, Branch of Quality Systems: accessed September 4, 2008 at http://bqs.usgs.gov/ltmdl/ 


